\title{
Modeling Water Temperatures and Brook Trout (Salvelinus fontinalis) Growth Potential Within a Complex Appalachian Riverscape
}

Michael Tincher

West Virginia University

Follow this and additional works at: https://researchrepository.wvu.edu/etd

\section{Recommended Citation}

Tincher, Michael, "Modeling Water Temperatures and Brook Trout (Salvelinus fontinalis) Growth Potential Within a Complex Appalachian Riverscape" (2013). Graduate Theses, Dissertations, and Problem Reports. 526.

https://researchrepository.wvu.edu/etd/526

This Thesis is protected by copyright and/or related rights. It has been brought to you by the The Research Repository @ WVU with permission from the rights-holder(s). You are free to use this Thesis in any way that is permitted by the copyright and related rights legislation that applies to your use. For other uses you must obtain permission from the rights-holder(s) directly, unless additional rights are indicated by a Creative Commons license in the record and/ or on the work itself. This Thesis has been accepted for inclusion in WVU Graduate Theses, Dissertations, and Problem Reports collection by an authorized administrator of The Research Repository @ WVU. For more information, please contact researchrepository@mail.wvu.edu. 
Modeling Water Temperatures and Brook Trout (Salvelinus fontinalis) Growth Potential Within a Complex Appalachian Riverscape

Michael Tincher

A Thesis submitted to

The Davis College of Agriculture, Natural Resources, and Design

at West Virginia University

in partial fulfillment of the requirements

for the degree of

Master of Science

in

Wildlife and Fisheries Resources

J. Todd Petty, Ph.D., Chair

Patricia Mazik, Ph.D.

Michael Shingleton, M.S.

Wildlife and Fisheries Resource Program

Division of Forestry and Natural Resources

Morgantown, WV

2013

Keywords: Water temperature modeling; brook trout; climate change; bioenergetics; growth potential; Appalachia;

Copyright 2012 Michael Tincher 


\begin{abstract}
Modeling Water Temperatures and Brook Trout (Salvelinus fontinalis) Growth Potential Within a Complex Appalachian Riverscape
\end{abstract}

Michael Tincher

Climate change is expected to cause air temperatures to increase $2-5^{\circ} \mathrm{C}$ in the Appalachians throughout the 21st century. These air temperature increases will cause water temperatures to increase, and may negatively effect cold and cool water fish species. Brook trout are an important game fish and highly vulnerable species in West Virginia. The primary objectives of this study were to (1) construct and validate models relating stream water temperature to long-term climate data for 18 sites and (2) determine brook trout growth potential within sites of the upper Shavers Fork watershed that differ in water temperature regimes. Multiple linear regression was used to construct models capable of predicting site-specific maximum and mean water temperature on the basis of climatic variables, including: air temperature, humidity, and stream flow. Validated water temperature models were then used to backcast maximum and mean temperatures from 2001-2012. Fish Bioenergetics 3.0 was used with backcasted mean water temperatures to estimate growth potential at each site for small and large adult brook trout. Sites were categorized as small tributary (ST), large tributary (LT), cool mainstem (CMS), and warm mainstem (WMS). Analysis of variance (ANOVA) was used to determine differences in growth between sites and seasons. Models predicting maximum and mean water temperature accounted for $82-95 \%$ of annual variation. Small adult growth is maximized in ST and LT sites, whereas large adult is maximized in CMS and WMS sites. Spring was the best season for growth, regardless of fish size or location. Specifically, CMS and WMS springs were the best site and season combination for growth. Summer had the lowest growth potential for all sites and sizes. 


\section{Acknowledgements}

I would like to thank my graduate committee, Dr. J. Todd Petty, Dr. Pat Mazik, and Mike Shingleton, for their assistance and guidance during my graduate study. I would especially like to thank Dr. Petty for his enthusiasm towards brook trout, Shavers Fork, and science in general. His enthusiasm is contagious and a great motivator. I would also like to thank Dr. Kyle Hartman for his assistance with Fish Bioenergetics 3.0.

I would like to give a special thanks to everyone that helped with placing and maintaining water temperature loggers before I started. This includes Jeff Hansbarger, Zach Liller, Dave Thorne, and Roy Martin. I am indebted to Eric Merriam and Brock Huntsman for their help in the field. I would also like to thank Donna Hartman and Eric Miller for their assistance with various aspects of the project. Finally, I would like to thank my family for their love and support throughout all of my endeavors. 


\section{Table of Contents}

Chapter 1: Modeling stream temperature in the Upper Shavers Fork watershed, WV ....1

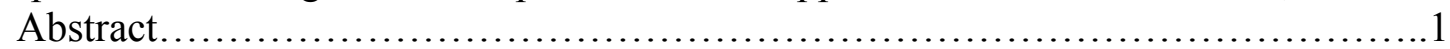

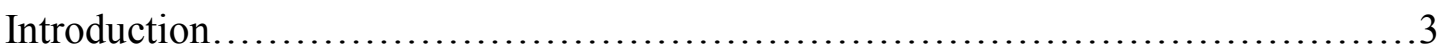

Methods........................................................................... 10

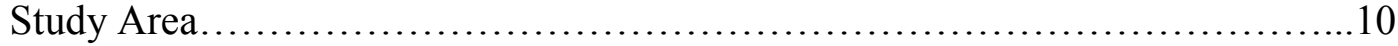

Long Term Water Temperature Prediction Models Data.........................11

Constructing Long Term Water Temperature Models............................11

Paired Air/Water Temperature Models Data...................................12

Constructing Paired Air/Water Temperature Models............................13

Backcasting Water Temperature Models.................................... 13

Results...................................................................... 14

Long Term Water Temperature Models...................................... 14

Paired Air/Water Temperature Models.................................... 16

Backcasting............................................................ 16

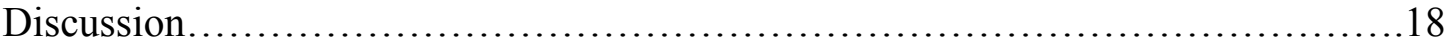

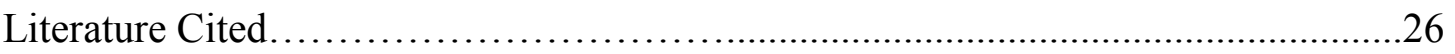

Tables and Figures.................................................... 34

Chapter 2: Quantifying brook trout growth potential within the Upper Shavers Fork

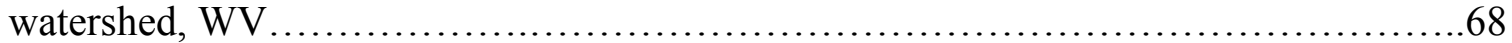

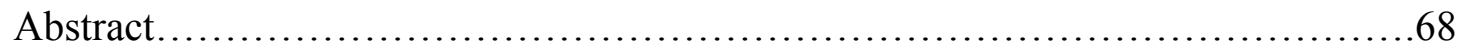

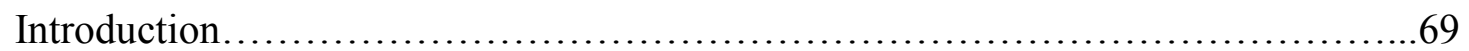

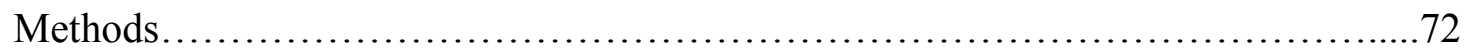

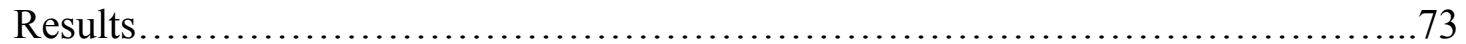

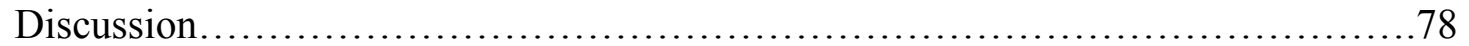

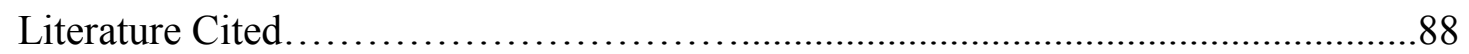

Tables and Figures.................................................. 94 


\title{
Chapter 1: Modeling stream temperature in the Upper Shavers Fork watershed, WV using a multiple linear regression approach.
}

\begin{abstract}
Climate change is expected to cause air temperatures to increase $2-5^{\circ} \mathrm{C}$ in the Appalachians throughout the 21 st century. These air temperature increases will cause water temperatures to increase, which may have a negative effect on brook trout survival. Brook trout are an important game fish and highly vulnerable species in West Virginia. A long term dataset of 18 study sites was selected in the upper Shavers Fork watershed to encompass various landscape variables. The objectives of this study were to (1) construct and validate models to predict maximum and mean water temperatures as a function of climatic variables and streamflow, and (2) determine whether models using local or regional air temperatures better predict water temperature. Water temperature loggers were placed at each site and have been monitored from 3-12 years. In 2011, air temperature loggers were paired with 17 water temperature loggers. Stepwise regression was used to determine the best predictor variables. Multiple linear regressions (MLR) were then performed for each site to create water temperature models. To determine whether local or regional air temperatures were better predictors, stepwise regression using local air temperature and other climatic variables was performed, followed by MLR for each site. Then, we replaced local air temperature with regional air temperature in these models and performed MLR. Akaike information criterion (AIC) scores for each model were then used to compare local and regional air temperatures. Models predicting maximum water temperature accounted for $82-93 \%$ of variation and models predicting mean water temperature accounted for $86-95 \%$ of variation. AIC scores showed regional
\end{abstract}


air temperature better predicted $59 \%$ of the time. In conclusion, our water temperature models were able to accurately predict water temperature. We were also able to highlight areas most vulnerable to climate change. 


\section{Introduction}

Brook trout (Salvelinus fontinalis) are an important sport fish species in the eastern United States. Brook trout populations have been declining in size and range throughout the Appalachians over the past century. Reasons for the decline include deforestation, acid precipitation, acid mine drainage, and introduction of non-native species (Marschall and Crowder 1996, Wigington et al. 1996). Climate change is another important factor that will potentially decrease brook trout populations throughout the $21^{\text {st }}$ century (Flebbe et al. 2006, Steen et al. 2010).

Acid precipitation is a common source of acidity in streams throughout the eastern United States (Marschall and Crowder 1996). Accumulated snowfall during the winter causes a build up of acid concentration. Subsequent spring snowmelt triggers fluctuations in acidity within a stream (Stottlemyer and Toczydlowski 1991). Many streams in the Appalachian Mountains are unable to buffer the increased acidity because of low-solubility rocks that define the streams (Hudy et al. 2000).

Acid mine drainage (AMD) is another devastating source of acid into Appalachian streams. Merovich and Petty (2006) showed that AMD can limit the functionality of streams. Acid precipitation and AMD have also been shown to severely reduce important biological functions, such as the break down of organic material (Young et al. 2008). However, adding limestone as a buffer to the stream has been proven to reduce acidity (McClurg et al. 2007).

Increased acidity is detrimental to brook trout and can decrease native populations (Marschall and Crowder 1996). High acid concentrations during spring snowmelt are harmful to many aquatic species since they are at sensitive stages in their life cycles 
(Laudon et al. 2004). This is especially true for brook trout since hatchlings stay in shallow water during the spring (Schindler 1988). The physiological problem with elevated acidity levels is it creates an osmotic imbalance in fish and can lead to death (Marschall and Crowder 1996). In fact, increased hydrogen ions and aluminum concentrations in acidic streams are often the primary toxicants to fish (Exley 1999, Serrano et al. 2008). High amounts of hydrogen ions hinder the uptake of sodium across fish gills, while increased aluminum decreases the amount of gill diffusion (Serrano et al. 2008).

Non-native species pose a threat to brook trout populations and range. Rainbow trout (Oncorhynchus mykiss) and brown trout (Salmo trutta) have been introduced into the Appalachian region and compete with brook trout. Rainbow trout have a higher growth rate than brook trout after their first year (Krueger and May 1991). Rainbow trout are also able to outcompete brook trout for preferred habitat, such as riffles and pools (Krueger and May 1991, Hasegawa et al. 2004). Brown trout are piscivorous and may feed upon small native brook trout (Krueger and May 1991).

Throughout the $20^{\text {th }}$ century, annual U.S. air temperatures have increased by $0.6^{\circ} \mathrm{C}$. If greenhouse effects are not reduced throughout the $21^{\text {st }}$ century, it is predicted that the annual U.S. air temperature will increase another $3-5^{\circ} \mathrm{C}$. Increased air temperatures can decrease biodiversity because some species will not be able to evolve and adapt to the climate change (National Assessment Synthesis Team 2001). Not only does global warming increase air temperature, it also has the potential to increase water temperatures (Hengeveld 1990, Isaak et al. 2010, Isaak et al. 2012). Therefore, climate change presents a major threat to the future of many cool and cold water fish species, 
including brook trout. Global warming may drive some fish distributions farther north and to higher altitudes towards cooler water temperatures (Meisner 1990). Increased water temperature can alter fish habitat. Also, flash floods may increase due to a higher probability of heavy downpours (National Assessment Synthesis Team 2001). Flebbe et al. (2006) predicts that if temperatures raise $3-5.5^{\circ} \mathrm{C}$, suitable habitat for brook, brown, and rainbow trout throughout the southern Appalachians will decrease by 53-97\%. Steen et al. (2010) predicts a similar outcome for brook trout throughout Michigan. Increasing temperatures will cause brook trout populations to become fragmented because there will only be small refuges in headwater streams at high elevations. Brook trout living in these fragmented refuges will face a high probability of extirpation because there will not be other sources of brook trout to repopulate the area after stochastic or deterministic events (Flebbe et al. 2006).

Understanding brook trout habitat, physiological characteristics, and spatial and temporal distribution are important for conceiving ideas to limit the effects of climate change. Foraging, refuge, and reproductive habitats are the three most important habitat types required by brook trout for growth and survival. Mainstem sites provide great foraging habitat, but often have sparse refuge habitats and no reproductive areas. Tributaries provide foraging habitat, although it is not as energetically profitable as the mainstem. Tributaries also bestow a variety of refuge and reproductive areas. Reproduction occurs only in the headwater tributaries (Petty et al. 2005). Juveniles may use undercut banks in headwater streams as cover from predators and refugia from floods (Petty et al. 2005). 
Typically, brook trout are considered drift feeders. However, brook trout from the Appalachian region may forage in benthic habitats (Sweka 2003). Fish and crayfish do not constitute a large amount of brook trout diet by number, but they yield a significant amount of brook trout diet by mass for fish in the upper Shavers Fork mainstem. Invertebrates comprise a large amount of brook trout diet by number (Hilderbrand and Kershner 2004a, Sweka and Hartman 2008).

Brook trout can gain a competitive advantage for food and spawning by increasing their size (Hutchings 1999). Optimum growth rate temperature for brook trout is $18^{\circ} \mathrm{C}$ with an ideal range of $13-21^{\circ} \mathrm{C}$ (Hartman and Sweka 2001). Increased temperatures may affect seasonal trout growth (Thorne 2004). High summer temperatures reduces growth rate of brook trout (Robinson et al. 2010) and they may start to lose energy once the temperature is above $21^{\circ} \mathrm{C}$ because of an increased metabolism (Hartman and Sweka 2001). However, food availability may be more indicative of trout growth than temperature in the upper Shavers Fork watershed (Thorne 2004). Brook trout growth rates are highest from spring to summer (Lamothe 2002, Thorne 2004, Utz and Hartman 2009). From midsummer until the following spring, growth rates remain very low (Utz and Hartman 2009). Juvenile brook trout display the highest growth rate. Large brook trout grow slowest from summer to fall (Lamothe 2002).

Fluvial salmonids, which migrate between tributaries to mainstem lotic habitats, tend to be larger than resident individuals of the same age. Many species, such as cutthroat trout (Oncorhynchus clarkii) and bull trout (Salvelinus confluentus), have been shown to have fluvial individuals more fit than residents (Hilderbrand and Kershner 2004b, Mogen and Kaeding 2005). Fluvial salmonids may temporarily experience 
reduced condition while migrating, but this will be counterbalanced when they reach a new habitat (Stolarski and Hartman 2010). However, larger brook trout are better prepared to endure migration to headwaters for fall spawning and overwintering (Hutchings 1999). Trout need to stay in the mainstem long term to fully benefit from the risks of migrating (Thorne 2004).

Hughes (1998) created a model that predicts larger fish will occur upstream when drift density decreases downstream, while smaller fish upstream will occur when drift density increases downstream. When salmonids occupy pools, the largest fish are located in the most upstream portion of the pool and are close to the center of current. As fish become smaller, they are located further downstream and move from the center current (Hughes 1998). Certain salmonids, such as coho salmon (Oncorhynchus kisutch) and steelhead (Oncorhynchus mykiss), have peak prey capture rates when velocity is between 0.25-40 m/s (Piccolo et al. 2008).

Some studies suggest that there is a linear relation between water and air temperatures (Webb et al. 2003). However, Mohseni and Stefan (1999) states that air and water temperatures have a logistic relationship. Usually, air and water temperatures do not display a linear relationship when water temperature is below $0^{\circ} \mathrm{C}$ or above $20^{\circ} \mathrm{C}$ (Mohseni and Stefan 1999, Webb et al. 2003). One reason for a logistic curve is because as air temperature decreases, water temperature reaches an asymptote at $0^{\circ} \mathrm{C}$. Another reason is because as air temperature increases, evaporative cooling prevents water temperature from increasing at the same rate (Mohseni and Stefan 1999).

Factors that may affect air and water temperature relationships include discharge, elevation, and groundwater inputs (Webb et al. 2003, Isaak et al. 2012). Air and water 
temperature relationships are stronger and less scattered when flow is below median discharge and does not display as strong of a relation when flow is above median discharge (Webb et al. 2003). There is not as strong of a relation when discharge is higher because of the increased thermal capacity of higher flows (Webb et al. 2003). Also, water temperature is inversely related to discharge (Webb et al. 2003). Elevation of the stream can influence air and water temperatures. Throughout the southern Appalachians, air temperature changes $1^{\circ} \mathrm{C}$ for every $188 \mathrm{~m}$ change in elevation (Flebbe et al. 2006). Groundwater inputs can alter water temperatures by cooling the stream in the summer and warming it in the winter. Groundwater temperature is about $1^{\circ} \mathrm{C}$ higher than the mean annual air temperature (Meisner et al. 1988).

Other factors influencing water temperature at a local scale include basin size, elevation, and segment gradient (Martin and Petty 2009). Martin and Petty (2009) showed that basin size, elevation, and segment gradient were good predictors for the mean weekly average temperature (MWAT) and weekly mean July temperature (WMJT). Mean weekly average temperature (MWAT) slightly underestimated lower and higher temperatures, while WMJT underestimated lower temperatures and overestimated higher temperatures (Martin and Petty 2009).

Brook trout survival has been shown to be lower during summers with higher water temperatures. It has also been shown that survival during low summer flows is dependent on size and site. Larger brook trout are the most negatively affected by low flows. Larger brook trout also have a higher survival rate in larger streams than in smaller streams. Conversely, smaller brook trout have a higher survival rate in smaller streams compared to larger streams (Xu et al. 2010). Drought conditions cause brook 
trout to have a lower body weight and lower Fulton's condition compared to brook trout living in non-drought conditions. Droughts reduce the habitat quality of streams. Food availability is also reduced during droughts. Low flows reduce fish cover within streams (Hakala and Hartman 2004). High summer temperatures can also reduce reproduction because of temperature induced mortality to mature brook trout (Robinson et al. 2010).

Upper temperature limits for brook trout have been calculated in laboratory settings and vary based on the method used. Critical thermal maximum (CTM) and ultimate upper incipient lethal temperature (UUILT) are two methods used to determine brook trout temperature limits. The CTM and UUILT for brook trout have been calculated as $29^{\circ} \mathrm{C}$ (Destaso and Rahel 1994) and $24.5^{\circ} \mathrm{C}$ (McCormick et al. 1972), respectively. Critical thermal maximum (CTM) involves quickly heating a fish until it loses equilibrium and cannot stay upright (Becker and Genoway 1979). Ultimate upper incipient lethal temperature (UUILT) involves exposure to high temperatures over a prolonged period and is determined as the temperature at which $50 \%$ mortality occurs in a species when exposed to that temperature for a 60 day period (Selong et al. 2001).

In the event that temperatures raise the predicted $3-5^{\circ} \mathrm{C}$ throughout this century, temperature may not be the primary determinant for declines in trout population (Flebbe et al. 2006). Despite all of the evidence showing the negative effects of high water temperature on trout, responses by macroinvertebrates and riparian vegetation may negatively influence trout populations before temperatures consistently reach lethal extremes (Flebbe et al. 2006).

Climate change poses a threat to the flora and fauna throughout the eastern United States. A diverse ichthyofauna is critical because of commercial and sports fisheries. 
Increasing air temperatures can cause water temperature to increase. In turn, fishes at the southern edge of their range could be pushed farther north or into higher elevations (Meisner 1990). Increased water temperatures can also affect the bioenergetics of species by causing their metabolism to rise, which could decrease growth (Hartman and Sweka 2001). Knowing the effect of altered air temperature and stream flow regimes on water temperature is vital for future understanding of thermal sensitive fish species, such as brook trout. It will help us better understand their spatial and temporal distribution and condition. Through a study assessing the water temperature regime in the Upper Shavers Fork watershed, our specific objectives were to: (1) construct and validate models to predict water temperature as a function of climatic variables and streamflow; and (2) determine whether models using air temperature from a regional climate station or local site specific air temperature better predicts water temperature.

\section{Methods}

\section{Study Area}

This study was conducted in the upper Shavers Fork watershed (Figure 1). The watershed is high elevation $(>1000 \mathrm{~m})$. First and Second Fork are two large tributaries that accounts for 26 percent of the basin area. Shavers Fork is a fifth order stream that flows north from Pocahontas County to Randolph County, where it merges with the Black Fork at Parsons, WV to form the Cheat River. Historically, this area had an abundant brook trout population. However, due to various anthropogenic factors, there has been a severe decline in brook trout population. 


\section{Long Term Water Temperature Prediction Models Data}

Water temperature was recorded at 18 different sites throughout the Upper Shavers Fork watershed. Monitoring at nine sites began in the spring of 2010. The remaining nine sites have been monitored nearly continuously since 2001 (Table 1). Years with no data for all sites included 2004, 2005, and 2009. The 18 sites were selected to encompass a variety of elevations, canopy covers, and basin areas.

There were several predictor variables considered for the models, including discharge, air temperature, and various other climatic parameters (Table 2). Discharge data was obtained from the United States Geological Survey (usgs.gov) stream site 03067510 Shavers Fork NR Cheat Bridge, WV, which is at the downstream extreme of the Upper Shavers Fork watershed. Air temperature, along with other climatic variables such as dew point and humidity, were obtained from Weather Underground's (wunderground.com) Elkins weather station, which is approximately $55 \mathrm{~km}$ north of the study area.

\section{Constructing Long Term Water Temperature Models}

Several response variables were considered when constructing temperature models. Response variables considered were daily maximum temperature, daily mean temperature, 7 day moving average (7DMA) of maximum temperature, and 7DMA of mean temperature (Table 3). Predictor variables were adjusted to a 7DMA when modeling 7DMA of max and mean water temperatures. A preliminary analysis showed the 7DMA of max and mean water temperatures produced more accurate models than the daily max and mean water temperatures. Therefore, only 7DMA of max and mean water 
temperatures were used as response variables in final models. Other studies have shown air and water temperature have a stronger correlation when using a weekly average instead of a daily value (Pilgrim et al. 1998, Erickson and Stefan 2000).

Predictor variables with a covariance $>0.90$ were identified as redundant and removed from subsequent analyses. Backwards stepwise regression was used to reduce the number of predictor variables in the models for each site. Variables were removed from the model if they failed an $F$ test and kept if they passed. The p-value used for the threshold was 0.15 . Multiple linear regressions were performed for each site with the remaining predictor variables (Pilgrim et al. 1998, Erickson and Stefan 2000, Flebbe et al. 2006, Martin and Petty 2009).

Holdout validation was also used on the dataset before creating the models. This validation method sets aside a subset of the data to be used as a test set, while the remaining data is used to create the models (training set) (Efron 1979, Kohavi 1995). The data was randomly split into $80 \%$ and $20 \%$ subsets for the training and test sets, respectively. Mean squared error (MSE) was used to compare the accuracy of the models with the training and test sets.

\section{Paired Air/Water Temperature Models Data}

From May 11, 2011 to October 30, 2011, air temperature loggers were paired with the 18 water temperature loggers. Air temperature loggers were placed in $75 \mathrm{~mm}$ diameter PVC pipe with a cap to minimize exposure to direct sunlight and as protection. Each pipe was $150 \mathrm{~mm}$ long. Air temperature loggers were also placed on the north side of trees adjacent to the stream to help minimize exposure to direct sunlight. 
The same predictor variables were considered for the paired air/water temperature models as in the water temperature prediction models. Discharge data was retrieved from the same location. All other variables were also retrieved from the same climate station in Elkins, WV. The only response variable used for the paired temperature models was 7DMA of maximum water temperature.

\section{Constructing Paired Air/Water Temperature Models}

Backwards stepwise regression was used to reduce predictor variables in the same manner. Predictor variables with a covariance $>0.90$ also had one of the two variables removed. The best predictor variables were then used in multiple linear regressions to obtain water temperature models with local air temperature influences at all 18 sites.

To determine if there was a stronger influence on water temperature by using local air temperature or a regional air temperature from a climate station, all 18 models were run again with multiple linear regressions. However, this time the local air temperature was replaced with the regional air temperature. All other variables used before in the local air temperature models remained the same. Akaike information criterion (AIC) scores for each model were then used to compare the local and regional air temperatures models at each site.

\section{Backcasting Water Temperature Models and Future Predictions}

The long-term water temperature models were then used to fill in any missing water temperature data from April 2001 to October 2011 for each of the 18 sites. This allows a continuous view on the temporal aspect of water temperature in Upper Shavers 
Fork. The number of days maximum water temperature exceeded $21^{\circ} \mathrm{C}$ each year at every site was estimated after all missing water temperatures were filled in with backcasting.

\section{Results}

\section{Long Term Water Temperature Models}

Shavers 43.0 was one of the warmest sites observed in the watershed. Maximum water temperature reached as high as $31.4^{\circ} \mathrm{C}$ in 2011 (Table 4). However, this site had a decrease in maximum water temperature in 2012. Mean water temperatures from June 1 to September 30 for Shavers 43.0, Shavers 43.8, and Shavers 89.1 were higher than all other sites (Table 5). Sites further upstream, such as Shavers 12.9, 20.7, and 27.9, displayed cooler maximum water temperatures than all other sites (Table 4). These same sites had lower average water temperatures, as well (Table 5). Minimum water temperatures for each site were relatively similar for each year (Table 6). Tributary sites never reached above $20^{\circ} \mathrm{C}$ (Table 4), while their average water temperatures for June 1 to September 30 ranged from $12.7^{\circ} \mathrm{C}$ to $14.9^{\circ} \mathrm{C}$ (Table 5). Typically, water temperature increased with drainage area (Figures 2-5). The mainstem would decrease in temperature when a tributary would enter.

Stepwise, multiple regression narrowed models from 37 possible predictor variables to 5-9 variables. There were a total of 13 different variables used among the 18 sites. Most common variables in the models included discharge (100\%), mean air temperature (100\%), mean humidity (83.3\%), and minimum humidity $(83.3 \%)$ (Table 7). 
Training sets for seven day moving average (7DMA) of the maximum water temperature models explained $82 \%$ to $94 \%$ of variation within water temperature, with the mean being $90 \%$ (Table 8 ). Shavers 59.4 had a noticeably lower $\mathrm{R}^{2}$ compared to the next lowest site ( 0.82 and 0.87 , respectively). Test data sets for 7DMA of the maximum water temperature showed similar results to the training sets (Table 9, Figures 6-11). The average training set had a mean square error of 2.00 (Table 8), while the test set averaged 1.28 (Table 9).

On average, training sets did not over-predict or under-predict water temperatures. The maximum overprediction was $6.0^{\circ} \mathrm{C}$ and the maximum underprediction was $5.6^{\circ} \mathrm{C}$ (Table 8). Test data did not overpredict or underpredict on average, with a maximum overprediction of $6.1^{\circ} \mathrm{C}$ and underprediction of $5.2^{\circ} \mathrm{C}$ (Table 9). Overpredictions occasionally occurred for training and test data when prolonged cold weather was immediately followed by a short warm spell (4-5 days). Underpredictions sporadically happened when prolonged warm weather was briefly interrupted by a few cool days (4-5 days). Typically, overpredictions occurred late in the fall (October), while underpredictions appeared during the early spring (April). The $5.6^{\circ} \mathrm{C}$ underprediction occurred at Shavers 43.0. The stream flows from east to west at this site and has low forest cover. This makes the site susceptible to having high water temperature because of its exposure to solar radiation. Sites with a cooler mean water temperature (Table 5) typically had smaller extreme overpredictions and underpredictions. Some of the cooler sites included Second 2.1, Second 3.4, Second 10.4, Shavers 20.7, and Shavers 27.9. These sites also have a smaller basin area compared to most other locations (Table 1), which may prevent severe water temperature fluctuations. 
Seven day moving average (7DMA) of the mean water temperature was also modeled. Training sets explained $86-95 \%$ of the variation, with the average being $93 \%$ for each site (Table 10). Shavers 59.4 again had a noticeably lower $\mathrm{R}^{2}$ value than next lowest site ( 0.86 and 0.90 , respectively). Test sets also showed a similar fit to training sets (Table 11). Training data had an average MSE of 1.39, while test data average MSE was 1.99. Training and test sets did not overpredict or underpredict on average. Training set maximum overprediction was $4.3^{\circ} \mathrm{C}$, while the maximum underprediction was $5.8^{\circ} \mathrm{C}$ (Table 10). Test set maximum overprediction was 4.0 and maximum underprediction was 3.6 (Table 11).

\section{Paired Air/Water Temperature Models}

Elkins air temperature was warmer than local air temperatures (Table 12). Comparing models with regional air temperature to local site specific air temperature showed local site specific air did not discern anymore variation for the majority of sites (Table 13, Figure 12). AIC comparisons showed 5 of 17 sites (29\%) were better with local air temperature, whereas regional air temperature was better for 10 sites (59\%). There was no difference between the remaining two sites. Overall, models using site specific air temperature data did not perform better than models based on regional air temperature data.

\section{Backcasting}

Backcasting was used to estimate water temperature when it was not available from 2001 to 2011. Shavers 43.8 and Shavers 89.1 had the highest maximum water 
temperatures each year (Tables 14-15). The stream channel of Shavers 43.8 is dominated by shallow glides and has little canopy cover. Shavers 89.1 is one of the largest sites. The warmest tributary was Second 15.4, which is also the largest tributary. Second 2.1 had higher temperatures than Second 3.4, despite their difference in watershed size. Second 2.1 is characterized by a relatively open riparian canopy.

Typical mainstem sites often experienced maximum daily water temperatures $>21^{\circ} \mathrm{C}$ (Figure 13). All mainstem sites were estimated to experience maximum daily water temperature $>21^{\circ} \mathrm{C}$ (Table 16). However, there is a wide range in the number of days that exceed this threshold depending on site. Maximum water temperature was estimated to have exceeded $>21^{\circ} \mathrm{C}$ only 2 times at Shavers 12.9 , the second most upstream mainstem site. Many other sites have exceeded the threshold numerous times, such as Shavers 41.1, Shavers 43.8, and Shavers 89.1 . Tributary sites generally remained below $21^{\circ} \mathrm{C}$ (Figure 14). Tributary sites play an important role in lowering water temperature. There is a noticeable decrease in the number of days $>21^{\circ} \mathrm{C}$ along the mainstem downstream of the confluences of Rocky Run and 2nd Fork compared to upstream river segments.

One of the warmest estimated years was 2005, but mean discharge (Figure 15) was lowest and average maximum air temperature was highest (Figure 16) during this year. The low discharge and high air temperature both appear to have influenced the high estimated water temperature. Water temperatures were low in 2003 and 2004, which also corresponded with some of the highest mean discharges and lowest average maximum air temperatures observed. There were slight negative correlations between discharge and maximum water temperature $\left(\mathrm{R}^{2}=0.32\right)$, as well as discharge and mean water 
temperature $\left(\mathrm{R}^{2}=0.28\right)($ Figure 17$)$. Maximum air and maximum water temperatures $\left(\mathrm{R}^{2}\right.$ $=0.55)$, mean air and mean water temperatures $\left(\mathrm{R}^{2}=0.56\right)$, and maximum air and mean water temperatures $\left(\mathrm{R}^{2}=0.52\right)$ were all positively correlated (Figure 18).

\section{Discussion}

Water temperatures varied spatially and temporally within the upper Shavers Fork watershed. Sites with a lower drainage area and sites directly downstream of tributary inputs typically had lower water temperatures. Air temperature and discharge are believed to greatly impact water temperatures (Webb et al. 2003, Isaak et al. 2012). Air temperature and discharge both influenced water temperatures, but air temperature had the greater affect.

Certain sites in the mainstem of Shavers Fork reach extreme temperatures. Sites such as Shavers 43.0 and Shavers 43.8, had remarkably higher water temperatures than other locations. Shavers 43.0 is noted for having little canopy cover and flowing from the east to west, which presents high probabilities of extreme water temperatures. Shavers 43.8 is characterized by a wide, shallow stream bed, which increases its vulnerability of high water temperatures by increased air temperatures. Contrary to this, sites such as Shavers 29.5 and Shavers 59.4 have lower water temperatures and could provide refugia for trout in the mainstem when water temperatures are elevated. Tributary locations do not have such extreme water temperatures and could also provide refugia during elevated water temperature events.

The 7DMA of maximum water temperatures had $\mathrm{R}^{2}$ values ranging from 0.82 to 0.94 , with a mean of 0.90 . Being able to explain $90 \%$ of variation in maximum water 
temperature on average at each site is a success. The 7DMA of mean water temperature had $\mathrm{R}^{2}$ values range from 0.86 to 0.95 , with a mean of 0.93 . Explaining $94 \%$ of variation in mean water temperature is also successful and comparable to similar studies. More importantly, models were validated and showed similar prediction accuracies between the training and test sets.

Most water temperature modeling studies have had some sort of relative success. Their accuracy is partially dependent on how many variables and which type of modeling (deterministic or stochastic) were used. Most linear regression models have used fewer explanatory variables than our models. Stefan and Preud'homme (1993) were able to explain $80 \%$ of variation in average water temperature solely using air temperature. Isaak et al. (2011) showed air temperature and discharge was able to discern $68 \%$ of variation in daily water temperature on average.

Air temperature and discharge are commonly used explanatory variables when predicting stream temperature. All of our models used mean air temperature and discharge. Several of the more commonly used explanatory variables in our models have rarely been used before. Mean humidity, mean barometric pressure, and mean visibility were some of the variables we used that are rarely used. Humidity can be important because it limits the amount of evaporative cooling. Barometric pressure can indicate good weather with clear skies. This may cause solar radiation to have a significant effect on stream temperature when there is little cloud cover. Visibility has a similar impact on stream temperatures.

Some studies have expanded the number of explanatory variables used for predicting water temperature. For instance, Martin and Petty (2009) created a water 
temperature model to predict weekly mean July water temperature for the Cheat River watershed, WV. Their model considered nine landscape variables, but AIC reduced the variables to cumulative stream length, watershed maximum elevation, and watershed relief ratio. Their model accounted for $81 \%$ of spatial variation in stream temperature.

Isaak et al. (2010) successfully used various meteorological and landscape attributes to create a multiple regressions model for predicting maximum weekly maximum water temperature and maximum weekly mean water temperature. Neumann et al. (2003) predicted daily stream temperature at one location based on (1) daily maximum stream temperature upstream of the site of interest, (2) daily maximum air temperature at the site of interest and above it, (3) average daily stream discharge from interested site and a separate upstream location, and (4) water release temperature from an upstream reservoir. The linear regression from this study was able to explain $91 \%$ of variation.

As evident from above, there are several successful explanatory variables that can be used to predict stream temperature with linear regression models. Our explanatory variables differ from the examples given, but all share similar predictive results. All models are able to describe large percentages of variation within stream temperature. However, what is unique about our study is that several of these variables are rarely used, easily obtainable, and may increase the explained variation of models compared to just using air temperature and/or discharge to predict stream temperature.

Nonlinear models have been suggested for modeling water temperature for streams that commonly rise above $25^{\circ} \mathrm{C}$ (Mohseni and Stefan 1999). Nonlinear models consistently had slightly better $\mathrm{R}^{2}$ values compared to linear models (Mohseni and Stefan 
1999, Kelleher et al. 2012). However, it has been proposed that nonlinear models will often underpredict maximum water temperature (Kelleher et al. 2012). Many of our sites commonly have maximum water temperatures above $25^{\circ} \mathrm{C}$. Since nonlinear models have been shown to underpredict maximum water temperatures and modeling maximum water temperature was one of our primary objectives, we decided to use linear regression. Even with the linear regression model, our models did not overpredict or underpredict on average.

Our models would often underpredict and overpredict water temperature during early spring and late fall. One of the reasons for these slight inaccuracies may have been because of drastic changing weather during these two periods. Even though we have modeled using a 7 day moving average, it can be difficult to account for drastic changes in air temperature and other weather patterns during early spring and late fall.

Sites with a cooler mean water temperature also have smaller differences between observed and predicted water temperature. Several factors may have contributed to the cooler mean temperatures and subsequent lower extremes of overprediction and underprediction. Typically, the cooler mean temperature also translates into smaller fluctuations in water temperature. Also, these sites had smaller basin areas and could typically be more affected by ground water inputs, which could cause the lower water temperatures.

Deterministic and stochastic models are often used for modeling water temperature. Deterministic models use a heat energy budget, along with meteorlogical variables, stream temperature, and site characteristics (Benyahya et al. 2007, Chenard and Caissie 2008). Deterministic models also require a plethora of data over an extended 
period of time (Benyahya et al. 2007, Chenard and Caissie 2008). This combination can make the models complicated and difficult to run. However, the models are accurate and are great for showing anthropogenic impacts on streams, such as the effects of a reservoir or deforestation (Benyahya et al. 2007).

Stochastic models, such as regression models, are simpler because they do not require as extensive data (Mohseni and Stefan 1999, Benyahya et al. 2007, Chenard and Caissie 2008). At its simplest, you only need continuous stream temperature and one other explanatory variable to create a linear regression (Stefan and Preud'homme 1993). Linear regression can continue to be used with multiple variables, which typically increases the models ability to explain the variance in water temperature (Martin and Petty 2009, Isaak et al. 2012). There are also other ways to stochastically model water temperature, such as artificial neural networks (Chenard and Caissie 2008). These other stochastic models are also less complicated relative to deterministic models.

Comparing water temperature models using regional air temperature with models using local air temperature showed local air temperature did not discern more variation in the models. Instead, for the majority of sites, regional air temperature produced better models. We were unable to find any studies that demonstrated whether a regional air temperature or local air temperature would perform better. One slightly similar study modeled stream temperature using air temperature from the closest air temperature station (Kelleher et al. 2012). The maximum distance was $32.5 \mathrm{~km}$ between the stream and air temperature site, but no minimum distance was given. Kelleher et al. (2012) concluded there was not a negative impact on their correlations. Mohseni et al. (1998) also determined that air temperature data could be separated from water temperature data 
as far as $270 \mathrm{~km}$ and still be suitable for modeling. These two studies show distance, up to a certain point, does not negatively impact correlations in models.

There are several factors that may have attributed to regional air temperature having better predictability than local air temperature. Influence of upstream conditions is a possibility for these results. Sun exposure and amount of thermal exchange could have caused variability in stream temperature that was not picked up by a local air temperature logger. A regional air temperature model might have been able to discern this pattern slightly better because it is more representative of the entire watershed, instead of one small microclimate. Variance in discharge may be another reason. If the discharge was low, stream temperatures could more easily be affected by sun exposure and thermal exchange (Isaak and Hubert 2001). The shaded local air temperature logger may not have been able to pick up on the additional temperature from the sun in its microclimate, which may have been discerned with the regional air temperature.

One of the downsides to our projects was there were only four tributary sites analyzed. Monitoring other tributary sites within the watershed may help give a slightly better overall understanding on how thermal regimes function in tributaries. However, the four tributary sites we did monitor covered a range of possibilities within the watershed. Open and closed canopy covers, different drainage areas, and different elevations were all considered when selecting tributary sites.

The study may also be improved by adding more sites in the mainstem of Shavers Fork. Adding more water temperature loggers in Shavers Fork would give us an even more detailed temperature regime. There is also the possibility of adding water 
temperature loggers to many of the deeper pools in the study area to determine how effective these isolated pools are for refugia purposes.

The models may have also been better predictors of water temperature if landscape characteristics (i.e. drainage area, slope, and aspect) were implemented into the model. For instance, Martin and Petty (2009) successfully used landscape attributes to model summer water temperatures. However, using more variables raises the question of what is too many? If there are too many variables used to explain variation in water temperature, this might lead to deceptively high $\mathrm{R}^{2}$ values and overly complex regression models. Also, water temperature models based on landscape characteristics have limited potential in predicting water temperatures in the presence of climate change.

Our water temperature models can be use for various tasks. Our models are able to highlight areas within the watershed that are most vulnerable to climate change, such as Shavers 43.8. This allows us to focus restoration efforts in specific areas. Our models highlight areas with the best trout refugia during the hottest days of the summer, which includes Shavers 29.5. Also, these models can be used to illustrate the potential growth of brook trout throughout the watershed for each year studied.

Currently, there are several restoration efforts occurring throughout upper Shavers Fork. These restoration efforts are aimed to lower water temperature by creating deeper pools, narrowing wide, shallow sections, and increasing velocity. This temperature data has the potential to create a before and after impact (BACI) study by comparing temperatures in upper Shavers Fork before and after the restoration is completed. In spring 2012, restoration work was performed in the area adjacent to Shavers 43.0. The maximum observed water temperature for 2012 was significantly lower than previous 
years. Although the average temperature was the same, there was less fluctuations in temperature for 2012 .

The models can be used as a template for predicting and monitoring stream temperatures. Combined with predicted future discharge conditions, these models can be useful in estimating the impacts climate change will have on water temperature in the upper Shavers Fork watershed. Subsequently, this can allow us to determine possible changes to brook trout habitat within the watershed and highlight specific areas that are vulnerable to climate change or act as refuge from climate change. 


\section{Literature Cited}

Becker, C.D. and R.G. Genoway. 1979. Evaluation of the critical thermal maximum for determining thermal tolerance of freshwater fish. Environmental Biology of Fishes 4:245-256.

Benyahya, L., D. Caissie, A. St-Hilaire, T.B.M.J. Ouarda, and B. Bobée. 2007. A review of statistical water temperature models. Canadian Water Resources Journal 32: 179-192.

Chenard, J.F. and D. Caissie. 2008. Stream temperature modeling using artificial neural networks: application on Catamaran Brook, New Brunswick, Canada. Hyrdological Processes 22: 3361-3372.

DeStaso, J. and F.J. Rahel. 1994. Influence of water temperature interactions between juvenile Colorado River cutthroat trout and brook trout in a laboratory stream. Transactions of the American Fisheries Society 123: 289-297.

Efron, B. 1979. Bootstrap methods: another look at the jackknife. Annals of Statistics 7: 1-26.

Erickson, T.R. and H.G. Stefan. 2000. Linear air/water temperature correlations for streams during open water periods. Journal of Hydrologic Engineering 5: 317-321.

Exley, C. 1999. Avoidance of aluminum by rainbow trout. Environmental Toxicology and Chemistry 19: 933-939.

Flebbe, P.A., L.D. Roghair, and J.L. Bruggink. 2006. Spatial modeling to project southern Appalachian trout distribution in a warmer climate. Transactions of the American Fisheries Society 135: 1371-1382. 
Hakala, J.P. and K.J. Hartman. 2004. Drought effect on stream morphology and brook trout (Salvelinus fontinalis) populations in forested headwater streams. Hydrobiologia 515: 203-213.

Hartman, K.J. and J.A. Sweka. 2001. Development of a bioenergetics model for Appalachian brook trout. Proceedings of the Southeastern Association of Fish and Wildlife Agencies 55:38-51.

Hasegawa, K., T. Yamamoto, M. Murakami, and K. Maekawa. 2004. Comparison of competitive ability between native and introduced salmonids: evidence from pairwise contests. Ichthyological Research 51: 191-194.

Hengeveld, H.G. 1990. Globat climate change: implications for air temperature and water supply in Canada. Transactions of the American Fisheries Society 119: 167-182.

Hilderbrand, R.H. and J.L. Kershner. 2004. Influence of habitat type on food supply, selectivity, and diet overlap of Bonneville cutthroat trout and nonnative brook trout in Beaver Creek, Idaho. North American Journal of Fisheries Management 24: $33-40$.

Hilderbrand, R.H. and J.L. Kershner. 2004. Are there differences in growth and condition between mobile and resident cutthroat trout? Transactions of the American Fisheries Society 133: 1042-1046.

Hudy, M., D.M. Downey, and D.W. Bowman. 2000. Successful restoration of an acidified native brook trout stream through mitigation with limestone sand. North American Journal of Fisheries Management 20: 455-466.

Hughes, N.F. 1998. A model of habitat selection by drift-feeding stream salmonids at 
different scales. Ecology 79: 281-294

Hutchings, J.A. 1999. Influence of sex, body size, and reproduction on overwinter lipid depletion in brook trout. Journal of Fish Biology 55: 1020-1028.

Isaak, D.J. and W.A Hubert. 2001. A hypothesis about factors that affect maximum summer stream temperatures across montane landscapes. Journal of the American Water Resources Association 37: 351-366.

Isaak, D.J., C.H. Luce, B.E. Rieman, D.E. Nagel, E.E. Peterson, D.L. Horan, S. Parkes, and G.L Chandler. 2010. Effects of climate change and wildfire on stream temperatures and salmonid thermal habitat in a mountain river network. Ecological Applications 20: 1350-1371.

Isaak, D.J., S. Wollrab, D. Horan, and G. Chandler. 2012. Climate change effects on stream and river temperatures across the northwest U.S. from 1980-2009 and implications for salmonid fishes. Climatic Change 133: 499-524.

Kelleher, C., T. Wagener, M. Gooseff, B. McGlynn, K. McGuire, and L. Marshall. 2012. Investigating controls on thermal sensitivity of Pennsylvania streams. Hyrdological Processes 26: 771-785.

Kohavi, R. 1995. A study of cross-validation and bootstrap for accuracy estimation and model selection. International Joint Conference on Artificial Intellegience 11371143.

Krueger, C.C., and B. May. 1991. Ecological and genetic effects of salmonid introductions in North America. Canadian Journal of Fisheries and Aquatic Sciences 48: 66-77.

Lamothe, P.J. 2002. Spatial population dynamics of brook trout (Salvelinus fontinalis) 
in a central Appalachian watershed. Master's Thesis, West Virginia University.

Laudon, H., A.B.S. Poleo, L.A. Vollestad, K. Bishop. 2004. Survival of brown trout during spring flood in DOC-rich streams in northern Sweden: the effect of present acid deposition and modeled pre-industrial water quality. Environmental Pollution 135: 121-130

Marschall, E. A. and L. B. Crowder. 1996. Assessing population responses to multiple anthropogenic effects: a case study with brook trout. Ecological Applications 6: $152-167$.

Martin, R.W. and J.T. Petty. 2009. Local stream temperature and drainage network topology interact to influence the distribution of smallmouth bass and brook trout in a central Appalachian watershed. Journal of Freshwater Ecology 24: 497-508.

McClurg, S.E., J.T. Petty, P.M. Mazik, and J.L Clayton. 2007. Stream ecosystem response to limestone treatment in acid impacted watersheds of the Allegheny Plateau. Ecological Applications 17: 1087-1104.

McCormick, J.H., K.E. Hokanson, and B.R. Jones. 1972. Effects of temperature on growth and survival of young brook trout, Salvelinus fontinalis. Journal of the Fisheries Research Board of Canada 29: 1107-1112.

Meisner, J.D., J.S. Rosenfeld, H.A. Regier. 1988. The role of groundwater in the impact of climate warming on stream Salmonines. Fisheries 13: 2-8.

Meisner, J.D. 1990. Potential loss of thermal habitat for brook trout, due to climate warming, in two southern Ontario streams. Transactions of the American Fisheries Society 119: 282-291. 
Merovich, G.T. and J.T. Petty. 2007. Interactive effects of multiple stressors and restoration priorities in a mined Appalachian watershed. Hydrobiologia 575: $13-31$

Mogen, J.T. and L.R. Kaeding. 2005. Identification and characterization of migratory and non-migratory bull trout populations in the St Mary River drainage, Montana. Transactions of the American Fisheries Society 134: 841-852.

Mohseni, O., H.G. Stefan, and T.R. Erickson. 1998. A non-linear regression model for weekly stream temperatures. Water Resources Research 34: 2685-2692.

Mohseni, O. and H.G. Stefan. 1999. Stream temperature/air temperature relationship: a physical interpretation. Journal of Hydrology 218: 128-141.

National Assessment Synthesis Team. 2001. Climate change impacts on the United States: the potential consequences of climate variability and change. Report for the U.S. Global Change Research Program. Cambridge University Press, Cambridge, UK.

Neumann, D.W., B. Rajagopalan, and E.A. Zagona. 2003. Regression model for daily maximum stream temperature. Journal of Environmental Engineering 129: 667674.

Petty , J.T., P.J. Lamothe, P.M. Mazik. 2005. Spatial and seasonal dynamics of brook trout populations inhabiting a central Appalachian watershed. Transactions of the American Fisheries Society 134: 572-587.

Piccolo, J.J., N.F. Hughes, and M.D. Bryant. 2008. Development of net energy intake models for drift-feeding juvenile coho salmon and steelhead. Environmental Biology of Fishes 83: 259-267. 
Pilgram, J.M., X. Fang, and H.G. Stefan. 1998. Stream temperature correlations with air temperatures in Minnesota: Implications for climate warming. Journal of the American Water Resources Association 34: 1109-1121.

Robinson, J.M., D.C. Josephson, B.C. Weidel, and C.E. Kraft. 2010. Influence of variable interannual summer water temperatures on brook trout growth, consumption, reproduction, and mortality in an unstratified Adirondack lake. Transactions of the American Fisheries Society 139: 685-699.

Schindler, D.S. 1988. Effects of acid raid on freshwater ecosystems. Science 239: 149157.

Selong, J.H., T.E. McMahon, A.V. Zale, and F.T. Barrows. 2001. Effect of temperature on growth and survival of bull trout, with application of an improved method for determining thermal tolerance in fishes. Transactions of the American Fisheries Society 130: 1026-1037.

Serrano, I., I. Buffman, D. Palm, E. Brannas, H. Laudon. 2008. Thresholds for survival of brown trout during the spring flood acid pulse in streams high in dissolved organic carbon. Transactions of the American Fisheries Society 137: 1363-1377.

Steen, P.J., M.J. Wiley, and J.S. Schaeffer. 2010. Predicting future changes in Muskegon River watershed game fish distributions under future land cover alteration and climate change scenarios. Transactions of the American Fisheries Society 139: 396-412.

Stefan, H.G. and E.B. Preud'homme. 1993. Stream temperature estimation from air temperature. Water Resources Bulletin 29: 27-45.

Stewart, M.F. 2010. Effects of acid mine drainage and acid precipitation on leaf litter 
breakdown rates in Appalachian headwater streams. Master's Thesis, West Virginia University.

Stolarski, J.T. and K.J. Hartman. 2010. Comparisons of growth and condition of fluvial and resident brook trout within partially migratory populations. Fisheries Management and Ecology 17: 33-39.

Stottlemyer, R. and D. Toczydlowski. 1991. Stream chemistry and hydrologic pathways During snowmelt in a small watershed adjacent Lake Superior. Biogeochemistry 13: 177-197.

Sweka, J.A. and K.J. Hartman. 2001. Effects of turbidity on prey consumption and growth in brook trout and implications for bioenergetics modeling. Canadian Journal of Fisheries and Aquatic Sciences 58: 386-393.

Sweka, J.A. and K.J. Hartman. 2008. Contribution of terrestrial invertebrates to yearly brook trout prey consumption and growth. Transactions of the American Fisheries Society 137: 224-235.

Thorne, D.W. 2004. Spatial and seasonal variation in brook trout diet, growth, and consumption in a complex Appalachian watershed. Master's Thesis, West Virginia University.

Utz, R.M. and K.J. Hartman. 2009. Density-dependent individual growth and size dynamics of central Appalachian brook trout (Salvelinus fontinalis). Canadian Journal of Fisheries and Aquatic Sciences 66: 1072-1080.

Webb, B.W., P.D. Clack, and D.E. Walling. 2003. Water-air temperature relationships in a Devon river system and the role of flow. Hydrological Processes 17: 30693084 
Wigington, P.J., J.P. Baker, D.R. DeWalle, W.A. Kretser, P.S. Murdoch, H.A. Simonin, J. Van Sickle, M.K. McDowell, D.V. Peck, W.R. Barchet. 1996. Episodic acidification of small streams in the northeastern United States: episodic response project. Ecological Applications 6: 374-388.

Xu, C.L., B.H. Letcher, and K.H. Nislow. 2010. Size-dependent survival of brook trout Salvelinus fontinalis in summer: effects of water temperature and stream flow. Journal of Fish Biology 76: 2342-2369.

Young, R.G., C.D. Matthaei, and C.R. Townsend. 2008. Organic matter breakdown and ecosystem metabolism: functional indicators for assessing river ecosystem health. Journal of North American Benthological Society 27: 605-662. 
Table 1. Drainage area $\left(\mathrm{km}^{2}\right)$, coordinates, years monitored, and sample size (n) for each site.

\begin{tabular}{lcccccc}
\hline Site & Detailed Site & Drainage Area $\left(\mathrm{km}^{2}\right)$ & Latitude & Longitude & $\mathrm{n}$ & Years Monitored \\
\hline Second 2.1 & Little Odey & 2.1 & 38.47734 & -79.9163 & 1217 & $2002-03,2006-07,2010-12$ \\
Second 3.4 & Upper 2nd & 3.4 & 38.46966 & -79.932 & 1336 & $2002-03,2006-08,2010-12$ \\
Second 10.4 & Gorge & 10.4 & 38.4851 & -79.9283 & 509 & $2010-12$ \\
Second 15.4 & Lower 2nd & 15.4 & 38.50246 & -79.9325 & 1090 & $2002-03,2008,2010-12$ \\
Shavers 7.5 & Dam & 7.5 & 38.42228 & -79.9795 & 366 & $2010-11$ \\
Shavers 12.9 & Ford & 12.9 & 38.43995 & -79.9623 & 364 & $2010-11$ \\
Shavers 20.7 & Spruce & 20.7 & 38.45435 & -79.9575 & 566 & $2010-12$ \\
Shavers 27.9 & Lamothe & 27.9 & 38.47315 & -79.9608 & 948 & $2002-03,2010-12$ \\
Shavers 29.5 & Twin Trestles & 29.5 & 38.47697 & -79.959 & 1377 & $2001-03,2006-08,2010-12$ \\
Shavers 31.7 & US Rocky & 31.7 & 38.48502 & -79.9585 & 579 & $2010-12$ \\
Shavers 38.7 & DS Rocky & 38.7 & 38.48651 & -79.9576 & 378 & $2010-11$ \\
Shavers 41.1 & Ryans Bend & 41.1 & 38.49557 & -79.9505 & 1364 & $2001-03,2006-07,2010-12$ \\
Shavers 43.0 & East to West & 43.0 & 38.50275 & -79.9426 & 579 & $2010-12$ \\
Shavers 43.8 & US 2nd & 43.8 & 38.50283 & -79.934 & 973 & $2002,2010-12$ \\
Shavers 59.4 & DS 2nd & 59.4 & 38.50625 & -79.9337 & 1098 & $2002-03,2007-08,2010,2012$ \\
Shavers 65.1 & Beaver & 65.1 & 38.52445 & -79.9354 & 557 & $2010-12$ \\
Shavers 89.1 & US 1st & 89.1 & 38.56643 & -79.8994 & 565 & $2010-12$ \\
Shavers 117.4 & DS 1st & 117.4 & 38.57431 & -79.9021 & 551 & $2001,2010-2011$ \\
\hline
\end{tabular}


Table 2. Variables considered for each water temperature model. Variables used indicated with $\mathrm{Y}$.

\begin{tabular}{lcccc}
\hline Variable & Max & Mean & Min & Other \\
\hline Julian Day & - & - & - & Y \\
Discharge & - & Y & - & - \\
Air Temperature & Y & Y & Y & - \\
Dew Point & Y & Y & Y & - \\
Humidity & Y & Y & Y & - \\
Barometric & & & & \\
Pressure & Y & Y & Y & - \\
Visibility & Y & Y & Y & - \\
Wind & Y & Y & - & - \\
Precipitation & - & - & - & Y \\
Cloud Cover & - & - & - & Y \\
\hline
\end{tabular}

Table 3. Response variables considered for modeling water temperature and their respective $\mathrm{R}^{2}$ value for a typical tributary and mainstem site (Second 3.4 and Shavers 29.5, respectively) and an atypical tributary and mainstem site (Second 2.1 and Shavers 43.0 , respectively).

\begin{tabular}{lcccc}
\hline Response Variable & Second 2.1 & Second 3.4 & Shavers 29.5 & Shavers 43.0 \\
\hline Daily Max & 0.76 & 0.84 & 0.74 & 0.78 \\
Daily Mean & 0.85 & 0.87 & 0.84 & 0.85 \\
7 Day Moving Average (7DMA) Max & 0.93 & 0.90 & 0.89 & 0.89 \\
7 Day Moving Average (7DMA) Mean & 0.94 & 0.93 & 0.92 & 0.93
\end{tabular}


Table 4. Maximum observed water temperature $\left({ }^{\circ} \mathrm{C}\right)$ from June 1 to September 30 for each site (2006 data used from June 16 to August 31).

\begin{tabular}{|c|c|c|c|c|c|c|c|c|c|}
\hline Site & 2001 & 2002 & 2003 & 2006 & 2007 & 2008 & 2010 & 2011 & 2012 \\
\hline Second 2.1 & - & 18.7 & 17.8 & 17.7 & 17.9 & - & 19.6 & 19.4 & 19.2 \\
\hline Second 3.4 & - & 17.5 & 16.8 & 17.3 & 17.1 & 16.4 & 16.5 & 17.5 & 18.9 \\
\hline Second 10.4 & - & - & - & - & - & - & 17.8 & 18.3 & 19.5 \\
\hline Second 15.4 & - & 19.5 & 18.9 & - & - & 18.5 & 19.7 & 22.6 & 22.5 \\
\hline Shavers 7.5 & - & - & - & - & - & - & 27.5 & 32.0 & - \\
\hline Shavers 12.9 & - & - & - & - & - & - & 21.7 & 24.0 & - \\
\hline Shavers 20.7 & - & - & - & - & - & - & 23.7 & 27.2 & 26.5 \\
\hline Shavers 27.9 & - & 25.1 & 23.8 & - & - & - & 25.0 & 28.4 & 29.0 \\
\hline Shavers 29.5 & 24.6 & 26.0 & 23.6 & 24.8 & 23.5 & 24.7 & 25.5 & 29.1 & 28.0 \\
\hline Shavers 31.7 & - & - & - & - & - & - & 25.8 & 29.2 & 28.0 \\
\hline Shavers 38.7 & - & - & - & - & - & - & 25.6 & 28.3 & - \\
\hline Shavers 41.1 & 24.4 & 25.1 & 23.9 & 26.6 & 25.0 & - & 28.0 & 29.6 & 30.1 \\
\hline Shavers 43.0 & - & - & - & - & - & - & 30.2 & 31.4 & 25.7 \\
\hline Shavers 43.8 & - & 27.5 & - & - & - & - & 27.9 & 30.6 & 29.5 \\
\hline Shavers 59.4 & - & 26.4 & 23.8 & - & 19.3 & 26.5 & 25.8 & - & 28.4 \\
\hline Shavers 65.1 & - & - & - & - & - & - & 29.2 & 30.5 & 31.7 \\
\hline Shavers 89.1 & - & - & - & - & - & - & 28.7 & 29.7 & 30.5 \\
\hline Shavers 117.4 & 26.4 & - & - & - & - & - & 27.8 & 29.2 & - \\
\hline
\end{tabular}


Table 5. Mean observed water temperature $\left({ }^{\circ} \mathrm{C}\right)$ from June 1 to September 30 for each site (2006 data used from June 16 to August $31)$.

\begin{tabular}{|c|c|c|c|c|c|c|c|c|c|}
\hline Site & 2001 & 2002 & 2003 & 2006 & 2007 & 2008 & 2010 & 2011 & 2012 \\
\hline Second 2.1 & - & 13.3 & 12.3 & 12.7 & 12.4 & - & 13.2 & 12.6 & 12.3 \\
\hline Second 3.4 & - & 13.7 & 12.2 & 13.4 & 12.8 & 12.6 & 13.1 & 13.1 & 13.3 \\
\hline Second 10.4 & - & - & - & - & - & - & 13.5 & 13.5 & 14.1 \\
\hline Second 15.4 & - & 14.7 & 13.1 & - & - & 14.1 & 14.6 & 14.8 & 14.9 \\
\hline Shavers 7.5 & - & - & - & - & - & - & 17.7 & 17.7 & - \\
\hline Shavers 12.9 & - & - & - & - & - & - & 16.1 & 16.0 & - \\
\hline Shavers 20.7 & - & - & - & - & - & - & 16.7 & 16.7 & 16.9 \\
\hline Shavers 27.9 & - & 17.3 & 15.5 & - & - & - & 17.2 & 17.3 & 17.4 \\
\hline Shavers 29.5 & 16.5 & 17.3 & 15.5 & 17.2 & 16.1 & 16.6 & 17.3 & 17.3 & 17.5 \\
\hline Shavers 31.7 & - & - & - & - & - & - & 17.2 & 17.2 & 17.5 \\
\hline Shavers 38.7 & - & - & - & - & - & - & 16.4 & 16.4 & - \\
\hline Shavers 41.1 & 16.0 & 17.3 & 15.5 & 17.7 & 16.7 & - & 17.6 & 17.6 & 18.1 \\
\hline Shavers 43.0 & - & - & - & - & - & - & 18.1 & 18.2 & 18.1 \\
\hline Shavers 43.8 & - & 18.3 & - & - & - & - & 18.8 & 18.7 & 19.1 \\
\hline Shavers 59.4 & - & 18.0 & 15.5 & - & 13.8 & 17.7 & 17.6 & - & 17.9 \\
\hline Shavers 65.1 & - & - & - & - & - & - & 18.2 & 18.2 & 18.6 \\
\hline Shavers 89.1 & - & - & - & - & - & - & 18.9 & 18.4 & 18.6 \\
\hline Shavers 117.4 & 17.2 & - & - & - & - & - & 18.4 & 17.8 & - \\
\hline
\end{tabular}


Table 6. Minimum observed water temperature $\left({ }^{\circ} \mathrm{C}\right)$ from June 1 to September 30 for each site (2006 data used from June 16 to August 31).

\begin{tabular}{|c|c|c|c|c|c|c|c|c|c|}
\hline Site & 2001 & 2002 & 2003 & 2006 & 2007 & 2008 & 2010 & 2011 & 2012 \\
\hline Second 2.1 & - & 8.7 & 6.5 & 8.6 & 8.0 & - & 8.6 & 7.7 & 6.6 \\
\hline Second 3.4 & - & 9.8 & 6.3 & 9.2 & 8.5 & 8.5 & 8.8 & 7.8 & 6.8 \\
\hline Second 10.4 & - & - & - & - & - & - & 8.9 & 8.0 & 6.5 \\
\hline Second 15.4 & - & 9.3 & 6.3 & - & - & 9.1 & 9.0 & 8.1 & 6.1 \\
\hline Shavers 7.5 & - & - & - & - & - & - & 8.9 & 12.9 & - \\
\hline Shavers 12.9 & - & - & - & - & - & - & 9.8 & 8.9 & - \\
\hline Shavers 20.7 & - & - & - & - & - & - & 9.7 & 8.3 & 7.0 \\
\hline Shavers 27.9 & - & 10.3 & 7.0 & - & - & - & 9.9 & 8.2 & 6.6 \\
\hline Shavers 29.5 & 8.8 & 9.6 & 6.8 & 10.8 & 8.4 & 9.4 & 9.7 & 8.1 & 6.6 \\
\hline Shavers 31.7 & - & - & - & - & - & - & 9.4 & 8.1 & 6.5 \\
\hline Shavers 38.7 & - & - & - & - & - & - & 9.4 & 8.2 & - \\
\hline Shavers 41.1 & 5.8 & 8.9 & 6.7 & 10.9 & 9.0 & - & 9.8 & 8.2 & 6.7 \\
\hline Shavers 43.0 & - & - & - & - & - & - & 10.1 & 8.0 & 6.7 \\
\hline Shavers 43.8 & - & 10.8 & - & - & - & - & 11.5 & 8.6 & 7.0 \\
\hline Shavers 59.4 & - & 11.0 & 6.7 & - & 8.3 & 11.1 & 10.7 & - & 6.9 \\
\hline Shavers 65.1 & - & - & - & - & - & - & 10.5 & 8.7 & 6.9 \\
\hline Shavers 89.1 & - & - & - & - & - & - & 11.2 & 9.4 & 7.6 \\
\hline Shavers 117.4 & 8.8 & - & - & - & - & - & 11.0 & 9.0 & - \\
\hline
\end{tabular}


Table 7. Variables used (Y) or not used (-) for each model. Day - Julian day ; Q - discharge ; A - air temperature ; P - precipitation ; $\mathrm{C}$ - cloud cover ; D - dew point ; H - humidity ; B - barometric pressure ; V - visibility ; W - wind speed.

\begin{tabular}{|c|c|c|c|c|c|c|c|c|c|c|c|c|c|c|}
\hline Site & Day & Q & $A_{\text {mean }}$ & Precip & Cloud & $\mathrm{H}_{\max }$ & $\mathrm{H}_{\text {mean }}$ & $\mathrm{H}_{\min }$ & $\mathrm{B}_{\text {mean }}$ & $\mathrm{V}_{\max }$ & $\mathrm{V}_{\text {mean }}$ & $\mathrm{V}_{\min }$ & $\mathrm{W}_{\max }$ & $\mathrm{W}_{\text {mean }}$ \\
\hline Second 2.1 & $\mathrm{Y}$ & $Y$ & $Y$ & - & $Y$ & - & $Y$ & $Y$ & $Y$ & - & $\mathrm{Y}$ & - & $\mathrm{Y}$ & $Y$ \\
\hline Second 3.4 & $Y$ & $Y$ & $Y$ & - & - & - & $Y$ & - & - & - & Y & - & Y & $Y$ \\
\hline Second 10.4 & $Y$ & $Y$ & $Y$ & - & - & $Y$ & - & $Y$ & - & - & $Y$ & - & - & $Y$ \\
\hline Second 15.4 & $Y$ & $Y$ & $Y$ & $Y$ & $Y$ & - & $Y$ & $Y$ & - & - & $Y$ & - & - & $Y$ \\
\hline Shavers 7.5 & $\mathrm{Y}$ & $\mathrm{Y}$ & $\mathrm{Y}$ & - & - & $\mathrm{Y}$ & $\mathrm{Y}$ & $\mathrm{Y}$ & - & - & $\mathrm{Y}$ & $\mathrm{Y}$ & $\mathrm{Y}$ & $Y$ \\
\hline Shavers 12.9 & $Y$ & $\mathrm{Y}$ & $\mathrm{Y}$ & - & $Y$ & - & - & $Y$ & $Y$ & - & - & $Y$ & $\mathrm{Y}$ & - \\
\hline Shavers 20.7 & $Y$ & $Y$ & $\mathrm{Y}$ & - & - & $\mathrm{Y}$ & $Y$ & $Y$ & $Y$ & - & - & $Y$ & $Y$ & - \\
\hline Shavers 27.9 & $Y$ & $Y$ & $Y$ & - & $Y$ & - & $Y$ & $\mathrm{Y}$ & $Y$ & - & - & - & $Y$ & - \\
\hline Shavers 29.5 & $\mathrm{Y}$ & $\mathrm{Y}$ & $Y$ & - & $Y$ & $\mathrm{Y}$ & $Y$ & $Y$ & - & - & $Y$ & - & - & - \\
\hline Shavers 31.7 & - & $\mathrm{Y}$ & $Y$ & $Y$ & $Y$ & - & $Y$ & $Y$ & $Y$ & - & - & $\mathrm{Y}$ & $Y$ & - \\
\hline Shavers 38.7 & $\mathrm{Y}$ & Y & $\mathrm{Y}$ & - & - & $\mathrm{Y}$ & $\mathrm{Y}$ & $Y$ & - & - & $\mathrm{Y}$ & $Y$ & $Y$ & $Y$ \\
\hline Shavers 41.1 & $\mathrm{Y}$ & $\mathrm{Y}$ & Y & - & - & $\mathrm{Y}$ & $Y$ & $\mathrm{Y}$ & - & - & Y & - & $\mathrm{Y}$ & - \\
\hline Shavers 43.0 & $\mathrm{Y}$ & $\mathrm{Y}$ & $Y$ & - & $\mathrm{Y}$ & $\mathrm{Y}$ & - & - & $Y$ & - & $Y$ & $Y$ & $Y$ & $Y$ \\
\hline Shavers 43.8 & $\mathrm{Y}$ & $\mathrm{Y}$ & $Y$ & - & $Y$ & - & $Y$ & $Y$ & - & - & - & - & $Y$ & - \\
\hline Shavers 59.4 & $Y$ & $Y$ & $Y$ & - & - & $Y$ & $Y$ & $Y$ & - & - & $Y$ & $Y$ & - & - \\
\hline Shavers 65.1 & - & $Y$ & $Y$ & - & - & $Y$ & $Y$ & $Y$ & $Y$ & - & $Y$ & $Y$ & - & $Y$ \\
\hline Shavers 89.1 & - & $Y$ & $Y$ & - & - & - & $Y$ & - & - & - & - & $Y$ & $Y$ & - \\
\hline Shavers 117.4 & - & $\mathrm{Y}$ & $\mathrm{Y}$ & $\mathrm{Y}$ & - & - & $\mathrm{Y}$ & $\mathrm{Y}$ & - & - & - & $\mathrm{Y}$ & $\mathrm{Y}$ & - \\
\hline Total & 14 & 18 & 18 & 3 & 8 & 9 & 15 & 15 & 7 & 0 & 11 & 10 & 13 & 8 \\
\hline Percent Used & 77.8 & 100.0 & 100.0 & 16.7 & 44.4 & 50.0 & 83.3 & 83.3 & 38.9 & 0.0 & 61.1 & 55.6 & 72.2 & 44.4 \\
\hline
\end{tabular}


Table 8. Training set $\mathrm{R}^{2}$ and mean squared error (MSE) values for each 7 day moving average (7DMA) of maximum water temperature model. Also, mean, maximum (overprediction), and minimum (underprediction) difference between observed and predicated 7DMA of maximum water temperatures.

\begin{tabular}{lccccc}
\hline Site & $\mathrm{R}^{2}$ & MSE & Max Difference $\left({ }^{\circ} \mathrm{C}\right)$ & $\begin{array}{c}\text { Mean Difference } \\
\left({ }^{\circ} \mathrm{C}\right)\end{array}$ & $\begin{array}{c}\text { Min Difference } \\
\left({ }^{\circ} \mathrm{C}\right)\end{array}$ \\
\hline Second 2.1 & 0.93 & 0.60 & 2.3 & 0.0 & -1.9 \\
Second 3.4 & 0.9 & 0.75 & 2.6 & 0.0 & -3.3 \\
Second 10.4 & 0.94 & 0.54 & 1.9 & 0.0 & -2.0 \\
Second 15.4 & 0.91 & 1.02 & 3.2 & 0.0 & -2.7 \\
Shavers 7.5 & 0.87 & 3.75 & 4.3 & 0.0 & -5.3 \\
Shavers 12.9 & 0.94 & 0.93 & 2.4 & 0.0 & -2.9 \\
Shavers 20.7 & 0.93 & 1.40 & 2.9 & 0.0 & -3.3 \\
Shavers 27.9 & 0.91 & 1.82 & 5.0 & 0.0 & -3.2 \\
Shavers 29.5 & 0.89 & 1.95 & 6.0 & 0.0 & -3.7 \\
Shavers 31.7 & 0.92 & 1.82 & 3.6 & 0.0 & -4.0 \\
Shavers 38.7 & 0.9 & 2.22 & 3.6 & 0.0 & -3.8 \\
Shavers 41.1 & 0.89 & 2.14 & 4.7 & 0.0 & -4.6 \\
Shavers 43.0 & 0.89 & 2.87 & 3.7 & 0.0 & -5.6 \\
Shavers 43.8 & 0.9 & 2.72 & 5.4 & 0.0 & -4.4 \\
Shavers 59.4 & 0.82 & 3.68 & 5.4 & 0.0 & -4.7 \\
Shavers 65.1 & 0.9 & 3.01 & 4.4 & 0.0 & -4.9 \\
Shavers 89.1 & 0.91 & 2.46 & 4.4 & 0.0 & -4.5 \\
Shavers 117.4 & 0.91 & 2.35 & 4.1 & 0.0 & -5.3 \\
Average & 0.90 & 2.00 & 3.9 & 0.00 & -3.88 \\
\hline
\end{tabular}


Table 9. Test set mean squared error (MSE) values for each 7 day moving average (7DMA) of maximum water temperature model. Also, mean, maximum (overprediction), and minimum (underprediction) difference between observed and predicated 7DMA of maximum water temperatures.

\begin{tabular}{lcccc}
\hline Site & MSE & $\begin{array}{c}\text { Max Difference } \\
\left({ }^{\circ} \mathrm{C}\right)\end{array}$ & $\begin{array}{c}\text { Mean Difference } \\
\left({ }^{\circ} \mathrm{C}\right)\end{array}$ & $\begin{array}{c}\text { Min Difference } \\
\left({ }^{\circ} \mathrm{C}\right)\end{array}$ \\
\hline Second 2.1 & 0.55 & 2.1 & 0.0 & -1.7 \\
Second 3.4 & 0.75 & 2.6 & -0.1 & -3.1 \\
Second 10.4 & 0.56 & 1.9 & 0.0 & -1.4 \\
Second 15.4 & 1.01 & 2.8 & 0.0 & -2.2 \\
Shavers 7.5 & 3.44 & 4.3 & 0.3 & -4.8 \\
Shavers 12.9 & 0.84 & 2.1 & -0.1 & -2.7 \\
Shavers 20.7 & 1.66 & 2.7 & 0.1 & -3.6 \\
Shavers 27.9 & 1.84 & 3.9 & 0.1 & -3.5 \\
Shavers 29.5 & 2.19 & 6.1 & 0.1 & -3.5 \\
Shavers 31.7 & 1.80 & 3.9 & 0.1 & -3.5 \\
Shavers 38.7 & 2.20 & 3.3 & 0.0 & -3.3 \\
Shavers 41.1 & 2.10 & 4.3 & -0.1 & -3.7 \\
Shavers 43.0 & 2.80 & 3.4 & -0.1 & -5.2 \\
Shavers 43.8 & 2.52 & 4.6 & -0.1 & -3.9 \\
Shavers 59.4 & 3.43 & 4.7 & -0.3 & -4.1 \\
Shavers 65.1 & 3.07 & 3.2 & -0.1 & -3.7 \\
Shavers 89.1 & 2.73 & 4.3 & 0.0 & -4.8 \\
Shavers 117.4 & 2.35 & 3.2 & -0.2 & -4.9 \\
Average & 1.99 & 3.5 & 0.0 & -3.5 \\
\hline
\end{tabular}


Table 10. Training set $\mathrm{R}^{2}$ and mean squared error (MSE) values for each 7 day moving average (7DMA) of mean water temperature model. Also, mean, maximum (overprediction), and minimum (underprediction) difference between observed and predicated 7DMA of maximum water temperatures.

\begin{tabular}{lrcccc}
\hline Site & $\mathrm{R}^{2}$ & MSE & Max Difference $\left({ }^{\circ} \mathrm{C}\right)$ & $\begin{array}{c}\text { Mean Difference } \\
\left({ }^{\circ} \mathrm{C}\right)\end{array}$ & $\begin{array}{c}\text { Min Difference } \\
\left({ }^{\circ} \mathrm{C}\right)\end{array}$ \\
\hline Second 2.1 & 0.94 & 0.55 & 2.0 & 0.0 & -2.0 \\
Second 3.4 & 0.93 & 0.38 & 2.1 & 0.0 & -1.8 \\
Second 10.4 & 0.95 & 0.44 & 1.6 & 0.0 & -1.8 \\
Second 15.4 & 0.93 & 0.81 & 3.0 & 0.0 & -2.2 \\
Shavers 7.5 & 0.9 & 3.66 & 1.8 & -1.3 & -5.8 \\
Shavers 12.9 & 0.95 & 0.78 & 1.9 & 0.0 & -2.6 \\
Shavers 20.7 & 0.94 & 2.05 & 3.7 & 1.0 & -2.1 \\
Shavers 27.9 & 0.93 & 1.19 & 3.9 & 0.0 & -2.7 \\
Shavers 29.5 & 0.92 & 1.13 & 3.9 & 0.0 & -3.2 \\
Shavers 31.7 & 0.94 & 1.13 & 3.5 & 0.0 & -3.1 \\
Shavers 38.7 & 0.94 & 1.46 & 3.2 & 0.3 & -3.5 \\
Shavers 41.1 & 0.92 & 1.28 & 3.7 & 0.0 & -3.4 \\
Shavers 43.0 & 0.93 & 1.51 & 3.3 & 0.0 & -3.5 \\
Shavers 43.8 & 0.92 & 1.80 & 4.3 & 0.0 & -3.7 \\
Shavers 59.4 & 0.86 & 2.36 & 4.3 & 0.0 & -3.9 \\
Shavers 65.1 & 0.93 & 1.52 & 3.6 & 0.0 & -3.4 \\
Shavers 89.1 & 0.93 & 1.51 & 3.7 & 0.0 & -3.8 \\
Shavers 117.4 & 0.93 & 1.43 & 3.5 & 0.0 & -3.6 \\
Average & 0.93 & 1.39 & 3.2 & 0.00 & -3.12 \\
\hline
\end{tabular}


Table 11. Test set mean squared error (MSE) values for each 7 day moving average (7DMA) of mean water temperature model. Also, mean, maximum (overprediction), and minimum (underprediction) difference between observed and predicated 7DMA of maximum water temperatures.

\begin{tabular}{lcccc}
\hline Site & MSE & $\begin{array}{c}\text { Max Difference } \\
\left({ }^{\circ} \mathrm{C}\right)\end{array}$ & $\begin{array}{c}\text { Mean Difference } \\
\left({ }^{\circ} \mathrm{C}\right)\end{array}$ & $\begin{array}{c}\text { Min Difference } \\
\left({ }^{\circ} \mathrm{C}\right)\end{array}$ \\
\hline Second 2.1 & 0.50 & 1.8 & 0.0 & -2.2 \\
Second 3.4 & 0.37 & 1.9 & -0.1 & -1.7 \\
Second 10.4 & 0.41 & 1.7 & 0.0 & -1.5 \\
Second 15.4 & 0.78 & 2.5 & 0.0 & -2.2 \\
Shavers 7.5 & 1.48 & 2.9 & 0.1 & -2.6 \\
Shavers 12.9 & 0.83 & 1.9 & -0.1 & -2.4 \\
Shavers 20.7 & 2.34 & 3.3 & 1.0 & -2.3 \\
Shavers 27.9 & 1.31 & 3.3 & 0.1 & -3.3 \\
Shavers 29.5 & 1.14 & 3.1 & 0.0 & -2.7 \\
Shavers 31.7 & 1.24 & 3.4 & 0.1 & -3.3 \\
Shavers 38.7 & 1.14 & 2.3 & -0.1 & -2.6 \\
Shavers 41.1 & 1.41 & 3.5 & 0.0 & -2.7 \\
Shavers 43.0 & 1.48 & 3.3 & -0.1 & -3.4 \\
Shavers 43.8 & 1.72 & 4.0 & 0.0 & -3.0 \\
Shavers 59.4 & 2.25 & 3.9 & -0.2 & -3.6 \\
Shavers 65.1 & 1.76 & 2.9 & 0.0 & -3.2 \\
Shavers 89.1 & 1.43 & 3.5 & 0.0 & -3.6 \\
Shavers 117.4 & 1.46 & 2.8 & -0.2 & -3.5 \\
Average & 1.28 & 2.9 & 0.0 & -2.8 \\
\hline
\end{tabular}


Table 12. 2011 observed air temperature $\left({ }^{\circ} \mathrm{C}\right)$ from May 11 to October 30 for 17 local sites and the regional site (Elkins, WV).

\begin{tabular}{lccc}
\hline Site & $\operatorname{Max}\left({ }^{\circ} \mathrm{C}\right)$ & Mean $\left({ }^{\circ} \mathrm{C}\right)$ & $\operatorname{Min}\left({ }^{\circ} \mathrm{C}\right)$ \\
\hline Second 2.1 & 27.6 & 15.6 & -1.8 \\
Second 3.4 & 25.5 & 15.5 & -0.6 \\
Second 10.4 & 26.1 & 15.4 & -1.1 \\
Second 15.4 & 29.6 & 16.0 & -1.8 \\
Shavers 7.5 & 27.3 & 16.0 & -1.8 \\
Shavers 12.9 & 28.6 & 16.0 & -1.6 \\
Shavers 20.7 & 30.6 & 16.2 & -2.3 \\
Shavers 27.9 & 28.3 & 16.0 & -1.3 \\
Shavers 29.5 & 28.1 & 15.9 & -1.4 \\
Shavers 31.7 & 28.4 & 16.1 & -1.2 \\
Shavers 38.7 & 28.4 & 16.1 & -1.3 \\
Shavers 41.1 & 28.5 & 16.3 & -1.4 \\
Shavers 43.0 & 27.1 & 16.0 & -0.7 \\
Shavers 43.8 & 28.5 & 16.2 & -1.0 \\
Shavers 65.1 & 29.1 & 16.5 & -0.8 \\
Shavers 89.1 & 30.2 & 16.6 & -0.1 \\
Shavers 117.4 & 27.6 & 16.2 & -0.8 \\
Elkins & 33.3 & 20.6 & 3.3 \\
\hline
\end{tabular}


Table 13. AIC scores for 7 day moving average (7DMA) of maximum water temperature models using regional and local air temperature.

\begin{tabular}{lcccc}
\hline Site & Regional & Local & Difference & Better \\
\hline Second 2.1 & 248.7 & 241.9 & 6.80 & Local \\
Second 3.4 & 186.9 & 195.2 & -8.24 & Elkins \\
Second 10.4 & 196.4 & 202.5 & -6.08 & Elkins \\
Second 15.4 & 279.5 & 287.0 & -7.51 & Elkins \\
Shavers 7.5 & 574.7 & 589.1 & -14.44 & Elkins \\
Shavers 12.9 & 293.2 & 293.9 & -0.77 & - \\
Shavers 20.7 & 385.5 & 394.1 & -8.58 & Elkins \\
Shavers 27.9 & 387.6 & 379.1 & 8.50 & Local \\
Shavers 29.5 & 404.7 & 402.5 & 2.17 & Local \\
Shavers 31.7 & 411.2 & 408.4 & 2.77 & Local \\
Shavers 38.7 & 453.6 & 463.2 & -9.59 & Elkins \\
Shavers 41.1 & 458.0 & 459.5 & -1.51 & - \\
Shavers 43.0 & 492.2 & 488.2 & 3.99 & Local \\
Shavers 43.8 & 488.4 & 497.8 & -9.41 & Elkins \\
Shavers 65.1 & 477.6 & 494.0 & -16.47 & Elkins \\
Shavers 89.1 & 440.1 & 473.2 & -33.18 & Elkins \\
Shavers 117.4 & 456.6 & 474.6 & -18.03 & Elkins \\
\hline
\end{tabular}


Table 14. Maximum estimated 7 day moving average maximum water temperature $\left({ }^{\circ} \mathrm{C}\right)$ using backcasting.

\begin{tabular}{|c|c|c|c|c|c|c|c|c|c|c|}
\hline Site & 2001 & 2002 & 2003 & 2004 & 2005 & 2006 & 2007 & 2009 & 2010 & 2012 \\
\hline Second 2.1 & 16.9 & 17.4 & 16.6 & 16.4 & 17.3 & 16.9 & 16.9 & 16.6 & 17.2 & 17.7 \\
\hline Second 3.4 & 15.8 & 16.0 & 15.7 & 15.4 & 16.2 & 16.1 & 16.0 & 15.7 & 16.7 & 16.8 \\
\hline Second 10.4 & 16.0 & 16.3 & 15.6 & 15.4 & 17.1 & 16.6 & 16.3 & 16.1 & 16.9 & 18.4 \\
\hline Second 15.4 & 18.1 & 18.6 & 17.7 & 17.4 & 18.8 & 18.5 & 18.5 & 18.2 & 18.9 & 19.8 \\
\hline Shavers 7.5 & 29.2 & 26.0 & 26.4 & 24.0 & 26.3 & 26.4 & 25.8 & 23.4 & 24.3 & 24.4 \\
\hline Shavers 12.9 & 20.4 & 20.2 & 19.6 & 19.2 & 20.6 & 20.6 & 20.0 & 19.7 & 20.7 & 21.2 \\
\hline Shavers 20.7 & 22.4 & 21.8 & 21.1 & 20.7 & 22.8 & 22.9 & 22.4 & 21.9 & 22.6 & 23.2 \\
\hline Shavers 27.9 & 23.1 & 23.5 & 22.1 & 22.0 & 24.3 & 23.0 & 22.7 & 22.5 & 22.9 & 24.8 \\
\hline Shavers 29.5 & 22.4 & 23.3 & 21.6 & 21.7 & 23.6 & 22.9 & 22.4 & 22.3 & 23.2 & 25.1 \\
\hline Shavers 31.7 & 24.2 & 23.4 & 22.6 & 22.5 & 24.0 & 23.9 & 23.1 & 22.6 & 23.4 & 24.3 \\
\hline Shavers 38.7 & 24.0 & 21.6 & 21.5 & 19.6 & 23.0 & 24.6 & 23.7 & 21.8 & 22.3 & 23.0 \\
\hline Shavers 41.1 & 22.9 & 23.8 & 21.8 & 22.1 & 24.0 & 23.7 & 23.5 & 23.3 & 23.9 & 25.9 \\
\hline Shavers 43.0 & 26.2 & 24.8 & 24.3 & 23.9 & 25.6 & 25.9 & 25.3 & 24.3 & 24.9 & 26.5 \\
\hline Shavers 43.8 & 24.9 & 25.4 & 23.5 & 23.6 & 26.3 & 25.1 & 24.6 & 24.3 & 24.9 & 27.2 \\
\hline Shavers 59.4 & 22.2 & 24.2 & 22.2 & 22.0 & 25.7 & 22.1 & 21.3 & 21.4 & 22.6 & 26.2 \\
\hline Shavers 65.1 & 29.8 & 26.5 & 26.4 & 24.9 & 26.7 & 26.6 & 25.9 & 23.8 & 24.8 & 24.6 \\
\hline Shavers 89.1 & 23.8 & 24.4 & 22.3 & 22.9 & 26.1 & 25.4 & 24.7 & 24.3 & 24.9 & 28.4 \\
\hline Shavers 117.4 & 24.8 & 24.8 & 23.2 & 23.6 & 25.4 & 24.3 & 24.4 & 23.6 & 24.4 & 26.2 \\
\hline
\end{tabular}


Table 15. Average estimated 7 day moving average maximum water temperature $\left({ }^{\circ} \mathrm{C}\right)$ using backcasting.

\begin{tabular}{|c|c|c|c|c|c|c|c|c|c|c|}
\hline Site & 2001 & 2002 & 2003 & 2004 & 2005 & 2006 & 2007 & 2009 & 2010 & 2012 \\
\hline Second 2.1 & 12.0 & 12.5 & 11.9 & 12.5 & 12.8 & 11.7 & 12.2 & 11.8 & 12.8 & 12.6 \\
\hline Second 3.4 & 10.9 & 11.4 & 10.9 & 11.5 & 12.0 & 10.9 & 11.4 & 11.1 & 11.9 & 11.8 \\
\hline Second 10.4 & 11.2 & 11.7 & 11.1 & 11.8 & 13.2 & 11.5 & 12.0 & 11.6 & 12.6 & 12.7 \\
\hline Second 15.4 & 12.6 & 13.2 & 12.5 & 13.2 & 14.0 & 12.5 & 13.3 & 12.8 & 13.9 & 13.8 \\
\hline Shavers 7.5 & 16.3 & 16.8 & 15.7 & 16.8 & 17.1 & 15.9 & 16.5 & 15.6 & 16.7 & 16.6 \\
\hline Shavers 12.9 & 13.8 & 14.4 & 13.6 & 14.5 & 15.2 & 13.6 & 14.4 & 13.9 & 14.9 & 14.7 \\
\hline Shavers 20.7 & 14.3 & 15.1 & 14.1 & 15.1 & 16.2 & 14.6 & 15.7 & 14.9 & 16.2 & 15.9 \\
\hline Shavers 27.9 & 15.9 & 16.4 & 15.2 & 16.4 & 17.6 & 15.5 & 16.5 & 15.5 & 17.0 & 17.0 \\
\hline Shavers 29.5 & 15.7 & 16.3 & 15.2 & 16.2 & 17.1 & 15.5 & 16.4 & 15.6 & 17.2 & 17.1 \\
\hline Shavers 31.7 & 15.7 & 16.3 & 15.1 & 16.3 & 17.1 & 15.4 & 16.5 & 15.5 & 16.9 & 16.7 \\
\hline Shavers 38.7 & 12.9 & 13.8 & 12.6 & 13.4 & 15.0 & 13.9 & 15.5 & 14.5 & 15.7 & 15.6 \\
\hline Shavers 41.1 & 15.6 & 16.3 & 15.1 & 16.3 & 17.6 & 15.7 & 16.8 & 15.9 & 17.6 & 17.6 \\
\hline Shavers 43.0 & 16.8 & 17.3 & 15.9 & 17.2 & 18.3 & 16.5 & 17.7 & 16.5 & 18.1 & 17.8 \\
\hline Shavers 43.8 & 16.8 & 17.4 & 16.0 & 17.4 & 19.0 & 16.5 & 17.6 & 16.5 & 18.3 & 18.3 \\
\hline Shavers 59.4 & 16.0 & 16.5 & 15.4 & 16.6 & 18.6 & 15.3 & 15.5 & 14.9 & 16.5 & 16.9 \\
\hline Shavers 65.1 & 17.6 & 18.0 & 16.4 & 17.8 & 18.1 & 16.0 & 17.7 & 16.3 & 18.0 & 17.4 \\
\hline Shavers 89.1 & 15.6 & 16.3 & 14.8 & 16.2 & 19.1 & 16.1 & 17.5 & 16.3 & 18.2 & 18.4 \\
\hline Shavers 117.4 & 16.4 & 16.9 & 15.6 & 17.0 & 18.2 & 16.0 & 16.8 & 15.8 & 17.5 & 17.5 \\
\hline
\end{tabular}


Table 16. Number of days 7 day moving average (7DMA) of maximum water temperature exceeds $21^{\circ} \mathrm{C}$.

\begin{tabular}{|c|c|c|c|c|c|c|c|c|c|c|c|}
\hline Site & 2001 & 2002 & 2003 & 2004 & 2005 & 2006 & 2007 & 2009 & 2010 & 2012 & Total \\
\hline Second 2.1 & 0 & 0 & 0 & 0 & 0 & 0 & 0 & 0 & 0 & 0 & 0 \\
\hline Second 3.4 & 0 & 0 & 0 & 0 & 0 & 0 & 0 & 0 & 0 & 0 & 0 \\
\hline Second 10.4 & 0 & 0 & 0 & 0 & 0 & 0 & 0 & 0 & 0 & 0 & 0 \\
\hline Second 15.4 & 0 & 0 & 0 & 0 & 0 & 0 & 0 & 0 & 0 & 0 & 0 \\
\hline Shavers 7.5 & 0 & 0 & 0 & 0 & 21 & 26 & 39 & 24 & 52 & 42 & 204 \\
\hline Shavers 12.9 & 0 & 0 & 0 & 0 & 0 & 0 & 0 & 0 & 0 & 2 & 2 \\
\hline Shavers 20.7 & 0 & 0 & 0 & 0 & 27 & 13 & 15 & 9 & 31 & 43 & 138 \\
\hline Shavers 27.9 & 15 & 48 & 27 & 17 & 71 & 26 & 27 & 10 & 49 & 53 & 343 \\
\hline Shavers 29.5 & 11 & 38 & 23 & 11 & 62 & 18 & 22 & 10 & 50 & 57 & 302 \\
\hline Shavers 31.7 & 4 & 7 & 0 & 1 & 88 & 25 & 28 & 14 & 60 & 61 & 288 \\
\hline Shavers 38.7 & 0 & 0 & 0 & 0 & 1 & 11 & 15 & 6 & 14 & 10 & 57 \\
\hline Shavers 41.1 & 43 & 82 & 50 & 58 & 100 & 52 & 60 & 53 & 79 & 67 & 644 \\
\hline Shavers 43.0 & 13 & 46 & 29 & 19 & 79 & 36 & 39 & 16 & 68 & 70 & 415 \\
\hline Shavers 43.8 & 44 & 88 & 52 & 51 & 110 & 51 & 60 & 42 & 89 & 81 & 668 \\
\hline Shavers 59.4 & 15 & 50 & 30 & 20 & 84 & 17 & 1 & 3 & 24 & 50 & 294 \\
\hline Shavers 65.1 & 0 & 0 & 0 & 0 & 25 & 13 & 11 & 7 & 19 & 21 & 96 \\
\hline Shavers 89.1 & 18 & 62 & 34 & 37 & 115 & 44 & 56 & 42 & 84 & 85 & 577 \\
\hline Shavers 117.4 & 34 & 76 & 48 & 51 & 97 & 48 & 43 & 23 & 66 & 67 & 553 \\
\hline
\end{tabular}


Table 17. Maximum estimated 7 day moving average mean water temperature $\left({ }^{\circ} \mathrm{C}\right)$ using backcasting.

\begin{tabular}{|c|c|c|c|c|c|c|c|c|c|c|}
\hline Site & 2001 & 2002 & 2003 & 2004 & 2005 & 2006 & 2007 & 2009 & 2010 & 2012 \\
\hline Second 2.1 & 14.7 & 14.8 & 14.6 & 14.2 & 14.6 & 14.6 & 14.7 & 14.2 & 15.1 & 15.2 \\
\hline Second 3.4 & 15.3 & 15.2 & 15.2 & 14.7 & 15.6 & 15.4 & 15.3 & 14.9 & 16.0 & 16.1 \\
\hline Second 10.4 & 15.9 & 15.8 & 15.6 & 15.2 & 16.6 & 15.7 & 15.6 & 15.2 & 16.2 & 16.8 \\
\hline Second 15.4 & 16.7 & 16.9 & 16.5 & 16.0 & 17.1 & 16.9 & 17.0 & 16.5 & 17.6 & 17.7 \\
\hline Shavers 7.5 & 22.0 & 21.1 & 21.2 & 21.0 & 21.4 & 20.6 & 20.1 & 19.4 & 21.2 & 21.1 \\
\hline Shavers 12.9 & 18.3 & 18.5 & 17.8 & 17.6 & 18.8 & 18.6 & 18.2 & 17.8 & 19.3 & 19.5 \\
\hline Shavers 20.7 & 20.4 & 19.8 & 19.5 & 19.2 & 20.1 & 19.7 & 19.1 & 18.6 & 20.1 & 20.1 \\
\hline Shavers 27.9 & 19.6 & 20.0 & 18.9 & 18.8 & 20.2 & 19.8 & 19.5 & 19.3 & 20.3 & 20.9 \\
\hline Shavers 29.5 & 19.5 & 19.9 & 19.0 & 18.7 & 20.0 & 19.9 & 19.6 & 19.3 & 20.4 & 21.0 \\
\hline Shavers 31.7 & 21.1 & 20.3 & 20.0 & 19.7 & 20.7 & 20.5 & 19.9 & 19.3 & 20.8 & 20.6 \\
\hline Shavers 38.7 & 19.5 & 19.5 & 18.9 & 18.5 & 19.4 & 19.6 & 20.1 & 19.0 & 20.5 & 20.5 \\
\hline Shavers 41.1 & 20.0 & 20.3 & 19.2 & 19.0 & 20.5 & 20.3 & 19.9 & 19.9 & 20.9 & 21.5 \\
\hline Shavers 43.0 & 19.7 & 19.7 & 18.7 & 19.0 & 21.7 & 21.7 & 20.7 & 20.5 & 21.8 & 23.7 \\
\hline Shavers 43.8 & 21.3 & 21.4 & 20.2 & 20.2 & 22.2 & 21.6 & 21.3 & 21.1 & 22.0 & 23.1 \\
\hline Shavers 59.4 & 19.4 & 20.7 & 19.3 & 19.0 & 21.5 & 19.3 & 19.1 & 19.0 & 20.3 & 22.3 \\
\hline Shavers 65.1 & 22.2 & 21.2 & 20.9 & 20.7 & 21.8 & 21.7 & 21.2 & 20.4 & 21.7 & 21.9 \\
\hline Shavers 89.1 & 21.6 & 21.5 & 20.3 & 20.4 & 22.3 & 21.8 & 21.1 & 21.0 & 22.0 & 23.3 \\
\hline Shavers 117.4 & 21.8 & 21.4 & 20.5 & 20.7 & 21.8 & 20.9 & 20.5 & 20.4 & 21.3 & 22.0 \\
\hline
\end{tabular}


Table 18. Average estimated 7 day moving average mean water temperature $\left({ }^{\circ} \mathrm{C}\right)$ using backcasting

\begin{tabular}{|c|c|c|c|c|c|c|c|c|c|c|}
\hline Site & 2001 & 2002 & 2003 & 2004 & 2005 & 2006 & 2007 & 2009 & 2010 & 2012 \\
\hline Second 2.1 & 10.4 & 10.8 & 10.5 & 10.9 & 10.8 & 10.0 & 10.4 & 10.2 & 10.8 & 10.6 \\
\hline Second 3.4 & 10.0 & 10.5 & 10.1 & 10.6 & 11.2 & 10.0 & 10.5 & 10.2 & 10.9 & 10.8 \\
\hline Second 10.4 & 10.7 & 11.1 & 10.6 & 11.3 & 12.2 & 10.5 & 10.8 & 10.5 & 11.3 & 11.3 \\
\hline Second 15.4 & 11.0 & 11.6 & 11.1 & 11.7 & 12.2 & 11.0 & 11.6 & 11.3 & 12.2 & 12.0 \\
\hline Shavers 7.5 & 14.6 & 15.1 & 14.5 & 15.3 & 15.1 & 13.8 & 14.0 & 13.7 & 14.4 & 14.2 \\
\hline Shavers 12.9 & 12.0 & 12.8 & 12.2 & 12.9 & 13.5 & 12.0 & 12.6 & 12.2 & 13.1 & 12.9 \\
\hline Shavers 20.7 & 13.0 & 13.6 & 12.9 & 13.8 & 14.0 & 12.5 & 13.1 & 12.6 & 13.6 & 13.3 \\
\hline Shavers 27.9 & 13.1 & 13.7 & 12.9 & 13.8 & 14.5 & 12.8 & 13.6 & 13.0 & 14.2 & 14.1 \\
\hline Shavers 29.5 & 13.0 & 13.6 & 12.8 & 13.7 & 14.3 & 12.8 & 13.6 & 13.1 & 14.2 & 14.1 \\
\hline Shavers 31.7 & 13.3 & 13.8 & 13.0 & 13.9 & 14.3 & 12.8 & 13.5 & 13.0 & 14.0 & 13.7 \\
\hline Shavers 38.7 & 12.7 & 13.4 & 13.0 & 13.6 & 13.6 & 12.7 & 13.5 & 13.1 & 14.2 & 13.7 \\
\hline Shavers 41.1 & 13.0 & 13.7 & 12.8 & 13.8 & 14.5 & 12.9 & 13.9 & 13.3 & 14.5 & 14.3 \\
\hline Shavers 43.0 & 12.0 & 12.7 & 11.7 & 12.7 & 15.3 & 12.8 & 14.2 & 13.5 & 14.8 & 14.9 \\
\hline Shavers 43.8 & 13.7 & 14.4 & 13.3 & 14.4 & 15.8 & 13.7 & 14.7 & 13.9 & 15.3 & 15.2 \\
\hline Shavers 59.4 & 13.3 & 13.9 & 13.0 & 14.0 & 15.5 & 12.9 & 13.2 & 12.8 & 14.0 & 14.2 \\
\hline Shavers 65.1 & 13.8 & 14.3 & 13.4 & 14.4 & 14.9 & 13.4 & 14.3 & 13.6 & 14.8 & 14.5 \\
\hline Shavers 89.1 & 13.8 & 14.4 & 13.3 & 14.5 & 15.8 & 13.8 & 14.7 & 13.9 & 15.3 & 15.4 \\
\hline Shavers 117.4 & 14.0 & 14.5 & 13.5 & 14.7 & 15.1 & 13.5 & 14.1 & 13.4 & 14.7 & 14.6 \\
\hline
\end{tabular}


Table 19. Minimum estimated 7 day moving average mean water temperature $\left({ }^{\circ} \mathrm{C}\right)$ using backcasting.

\begin{tabular}{|c|c|c|c|c|c|c|c|c|c|c|}
\hline Site & 2001 & 2002 & 2003 & 2004 & 2005 & 2006 & 2007 & 2009 & 2010 & 2012 \\
\hline Second 2.1 & 1.3 & 3.0 & 4.0 & 2.6 & 4.6 & 4.4 & 0.1 & 3.0 & 4.0 & 3.7 \\
\hline Second 3.4 & -0.3 & 1.2 & 2.5 & 1.2 & 2.6 & 2.8 & -0.8 & 1.8 & 2.1 & 3.2 \\
\hline Second 10.4 & 0.6 & 1.9 & 3.1 & 2.0 & 3.4 & 3.4 & 0.0 & 2.5 & 2.8 & 4.5 \\
\hline Second 15.4 & -0.3 & 1.7 & 2.8 & 1.1 & 3.5 & 3.4 & -1.5 & 2.1 & 3.0 & 3.6 \\
\hline Shavers 7.5 & 2.2 & 3.3 & 5.1 & 3.8 & 3.3 & 5.5 & 0.3 & 3.1 & 2.8 & 5.0 \\
\hline Shavers 12.9 & 0.3 & 2.5 & 3.5 & 1.8 & 4.5 & 4.2 & -1.4 & 2.2 & 3.2 & 3.7 \\
\hline Shavers 20.7 & 0.4 & 2.2 & 3.7 & 2.0 & 2.6 & 4.2 & -1.6 & 2.1 & 2.3 & 4.2 \\
\hline Shavers 27.9 & 0.0 & 2.6 & 3.3 & 1.5 & 2.9 & 3.7 & -1.6 & 2.5 & 3.6 & 4.4 \\
\hline Shavers 29.5 & 0.0 & 2.5 & 3.5 & 1.7 & 2.9 & 3.6 & -1.3 & 2.7 & 3.7 & 4.7 \\
\hline Shavers 31.7 & 0.3 & 2.2 & 3.3 & 1.4 & 1.5 & 3.8 & -1.5 & 2.1 & 2.0 & 4.8 \\
\hline Shavers 38.7 & -0.4 & 1.5 & 3.4 & 1.5 & 4.0 & 3.4 & -2.6 & 2.7 & 4.3 & 3.2 \\
\hline Shavers 41.1 & -0.1 & 2.5 & 3.1 & 1.1 & 2.5 & 2.9 & -2.2 & 2.2 & 3.2 & 4.3 \\
\hline Shavers 43.0 & -0.3 & 2.1 & 2.0 & 0.2 & 0.5 & 2.6 & -0.7 & 2.5 & 2.3 & 5.9 \\
\hline Shavers 43.8 & -0.3 & 2.4 & 3.1 & 1.1 & 2.4 & 3.2 & -1.8 & 2.5 & 3.2 & 5.3 \\
\hline Shavers 59.4 & -0.9 & 1.9 & 3.4 & 1.3 & 3.9 & 4.2 & -0.1 & 2.7 & 3.5 & 5.6 \\
\hline Shavers 65.1 & 0.5 & 2.3 & 2.7 & 0.6 & 0.5 & 3.4 & -1.7 & 2.1 & 1.7 & 5.1 \\
\hline Shavers 89.1 & 0.9 & 2.7 & 2.8 & 0.7 & 0.3 & 2.5 & -1.1 & 2.6 & 2.4 & 6.2 \\
\hline Shavers 117.4 & 1.1 & 2.7 & 3.2 & 1.3 & 0.3 & 2.4 & -1.6 & 2.1 & 2.2 & 4.9 \\
\hline
\end{tabular}




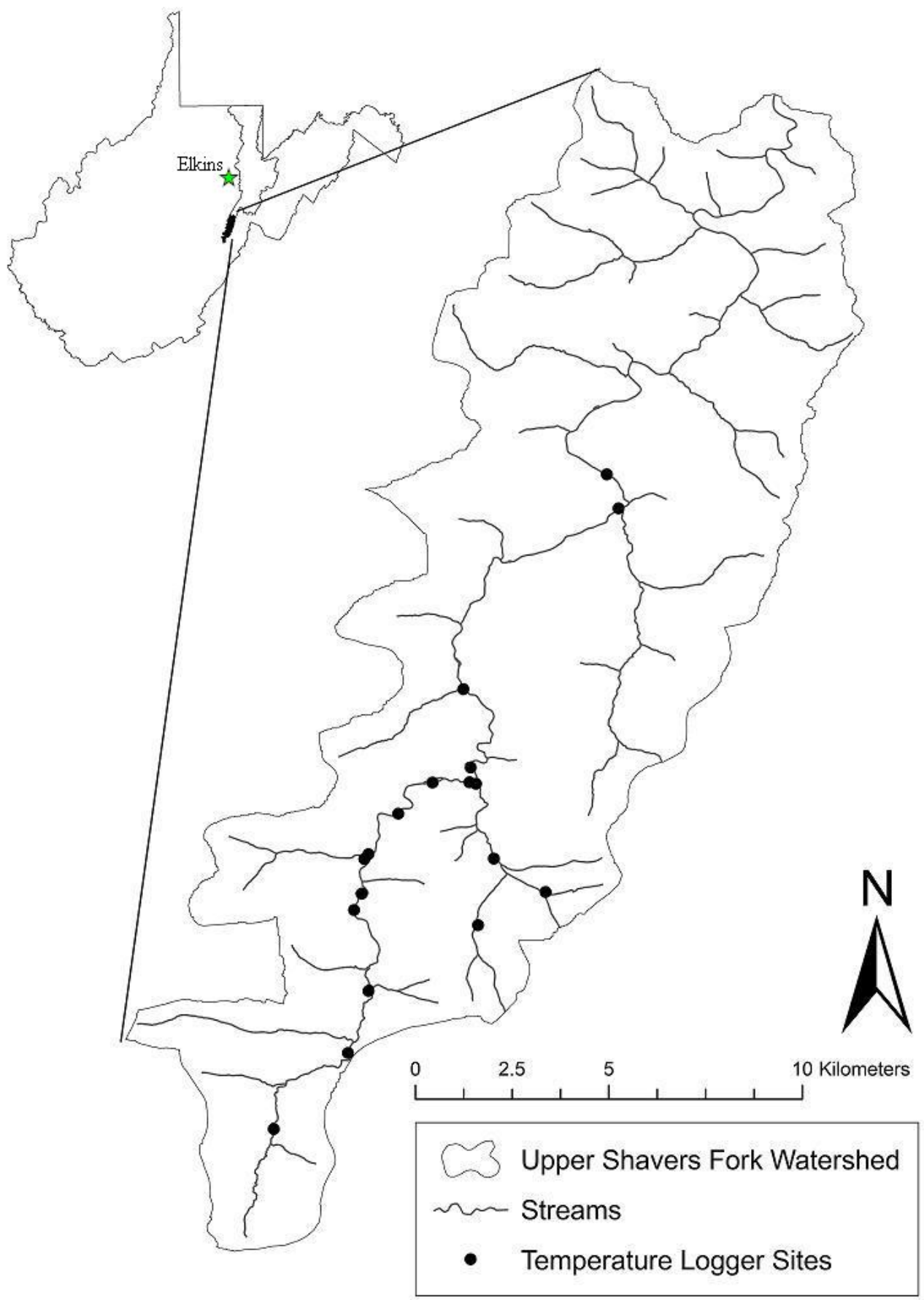

Figure 1. Location of temperature loggers within the Upper Shavers Fork watershed. 


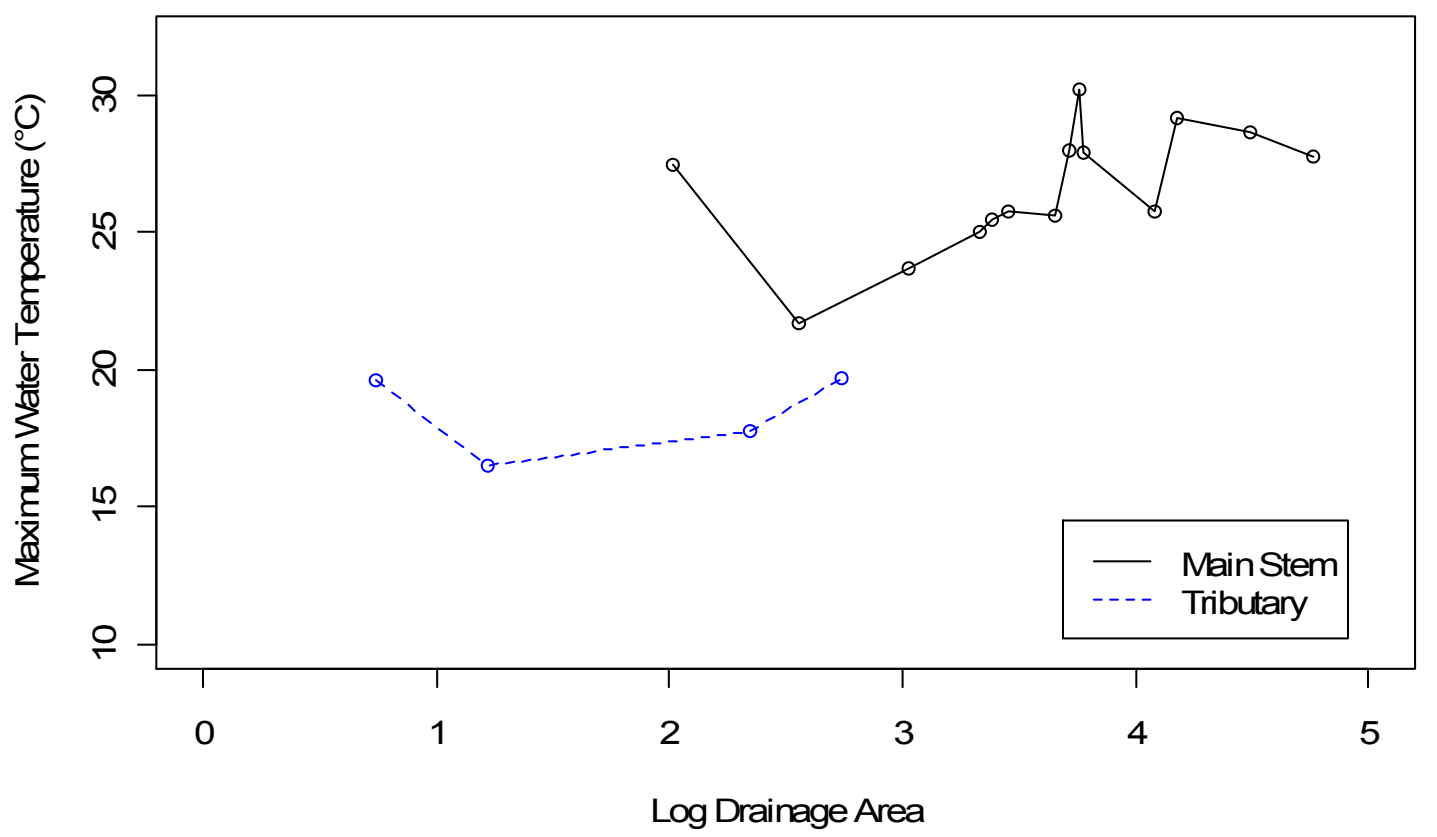

Figure 2. Observed maximum water temperature spatial profile for mainstem and tributary sites in 2010 .

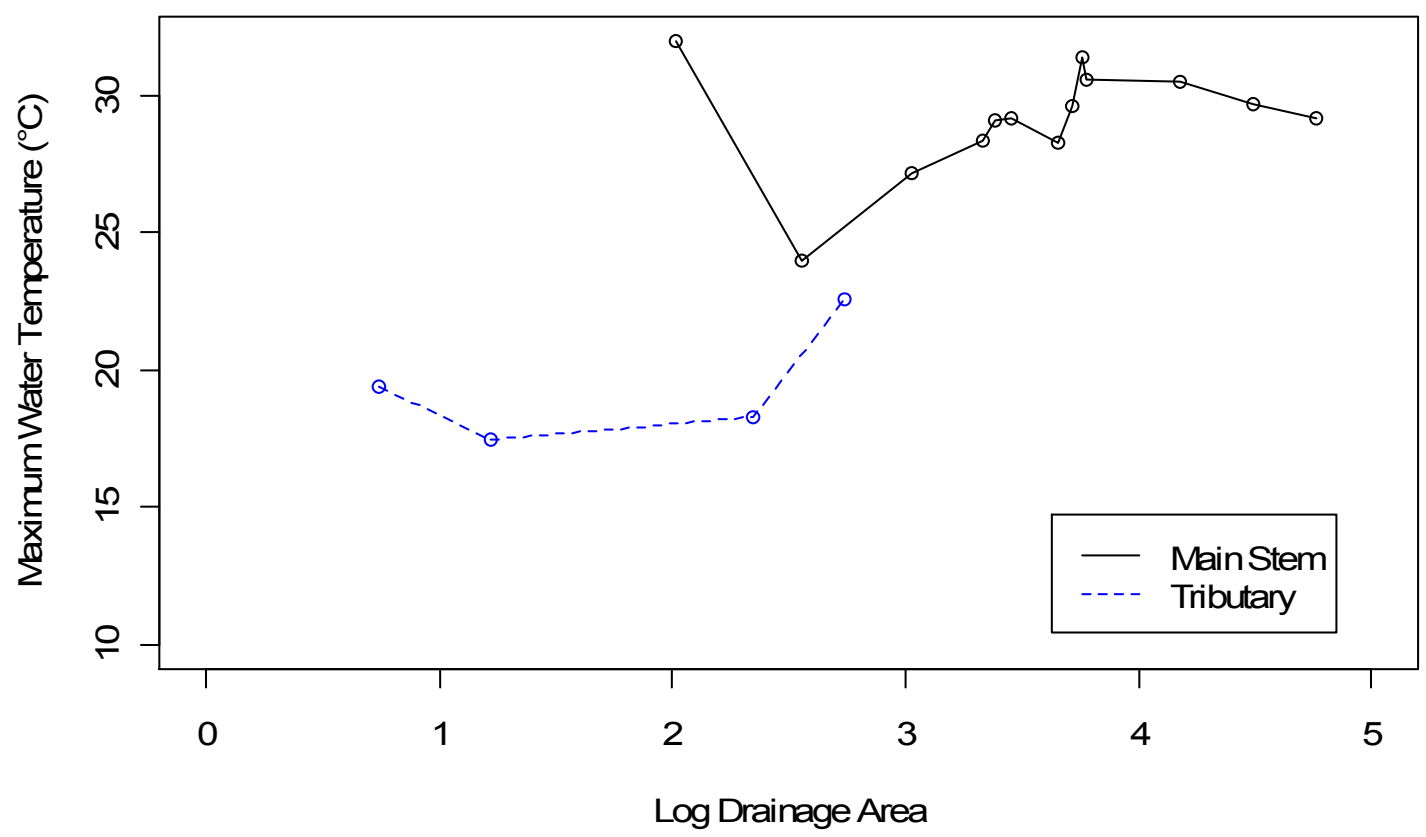

Figure

3. Observed maximum water temperature spatial profile for mainstem and tributary sites in 2011. 


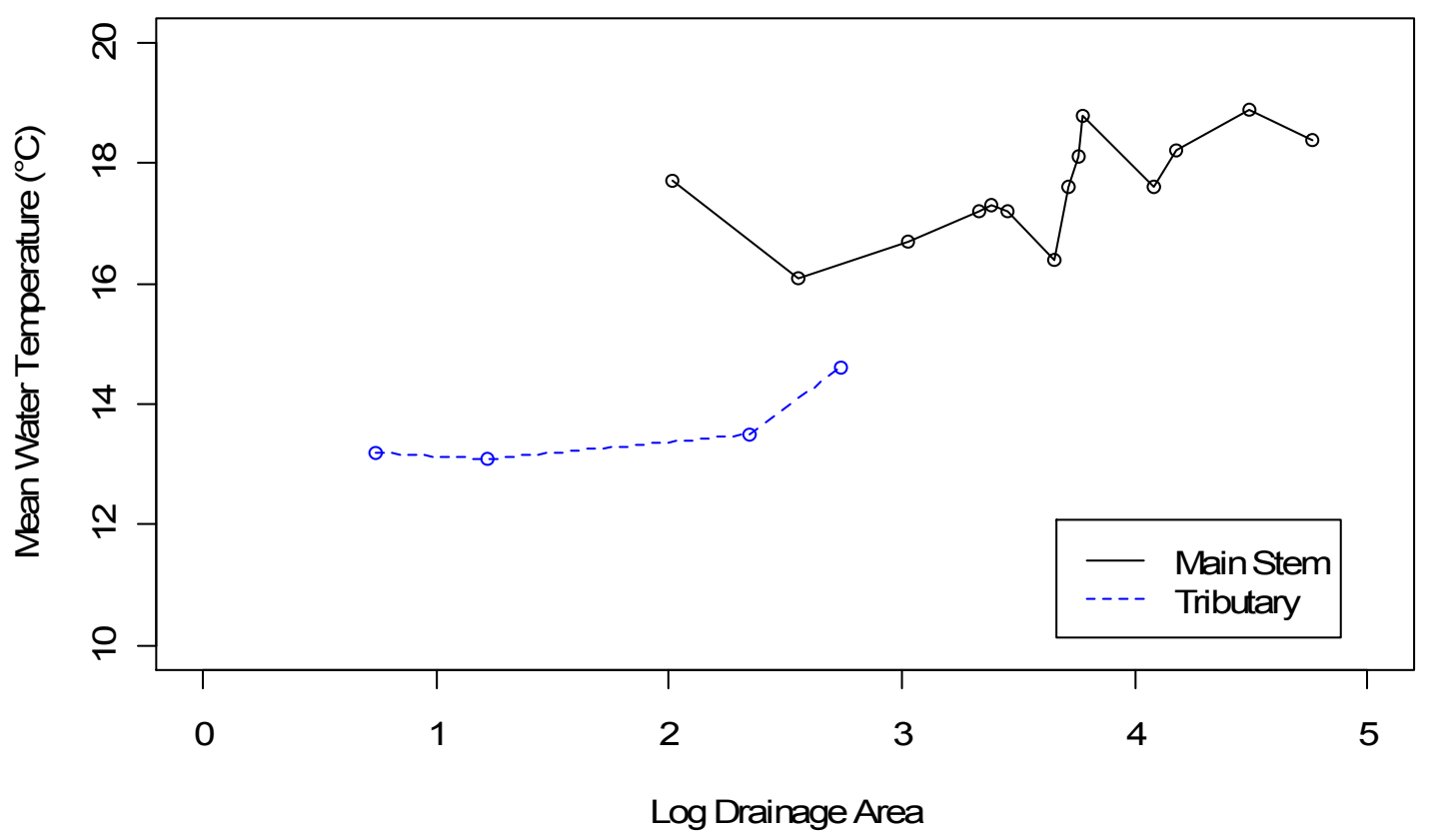

Figure 4. Observed mean daily water temperature spatial profile for mainstem and tributary sites in 2010.

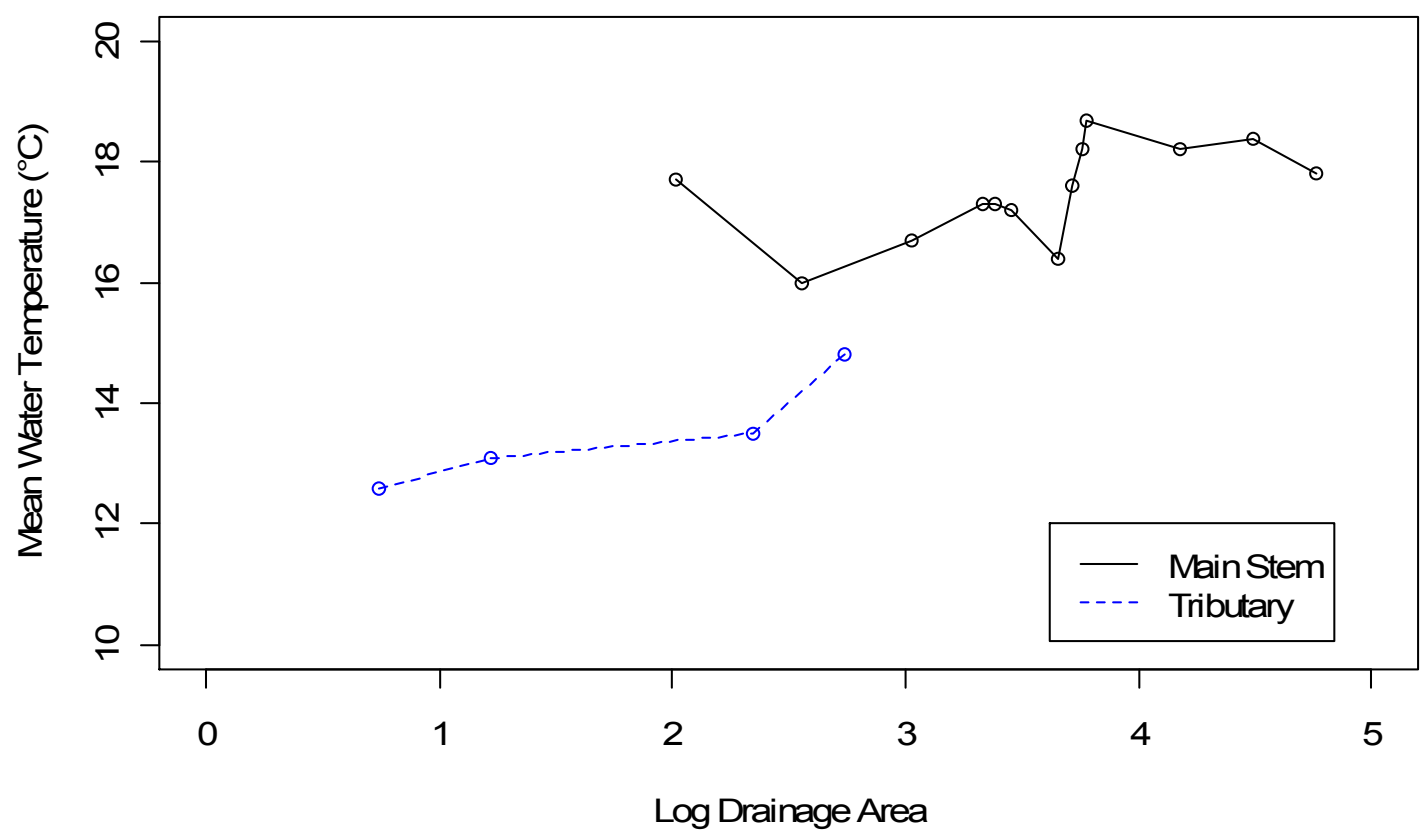

Figure 5. Observed mean daily water temperature spatial profile for mainstem and tributary sites in 2011. 


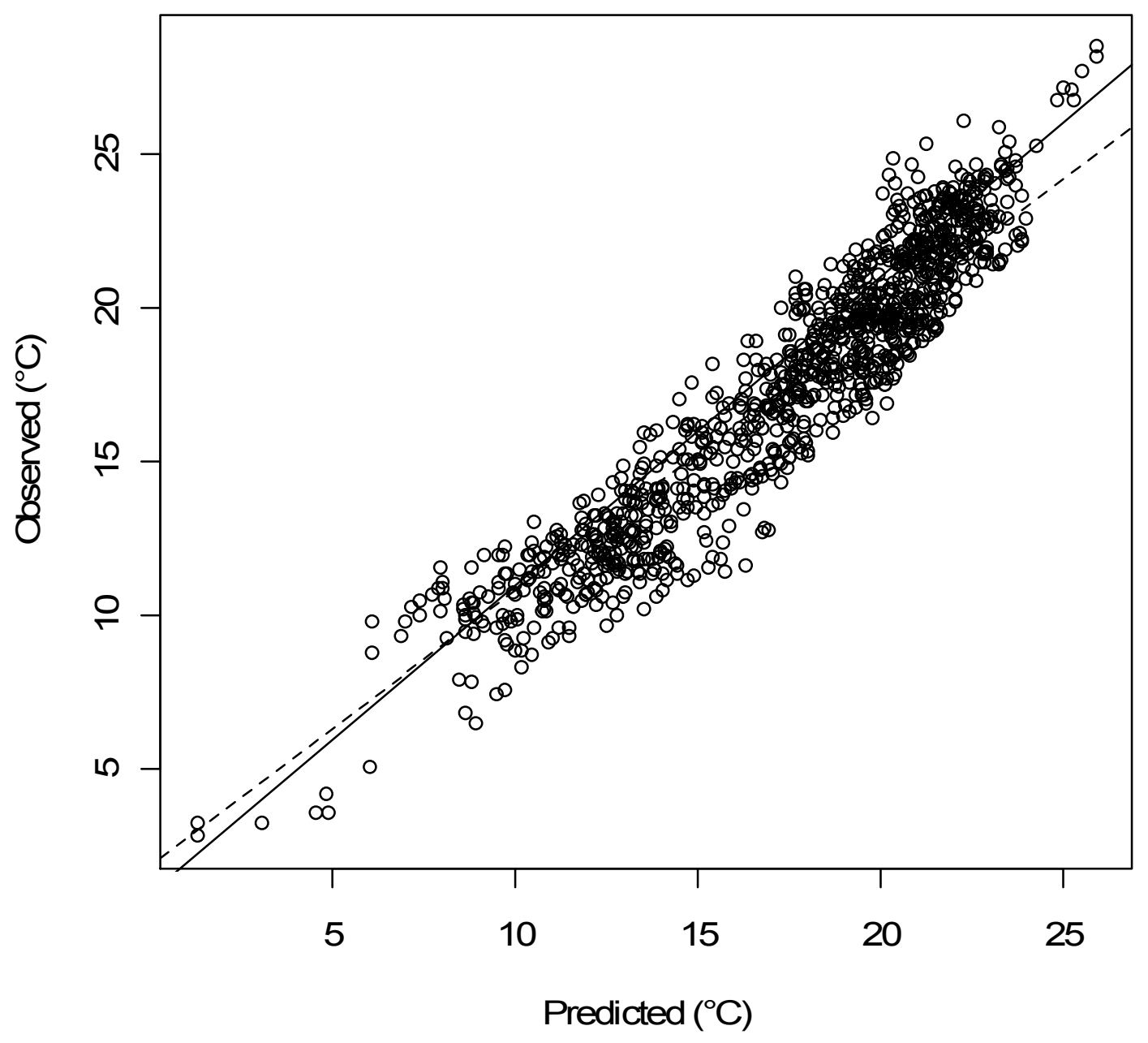

Figure 6. Observed vs. predicted 7 day moving average (7DMA) of maximum water temperature using training data for Shavers $41.1\left(\mathrm{R}^{2}=0.89\right)$, which is a typical mainstem site. Solid line is a 1:1 line. Dashed line is a best fit line. 


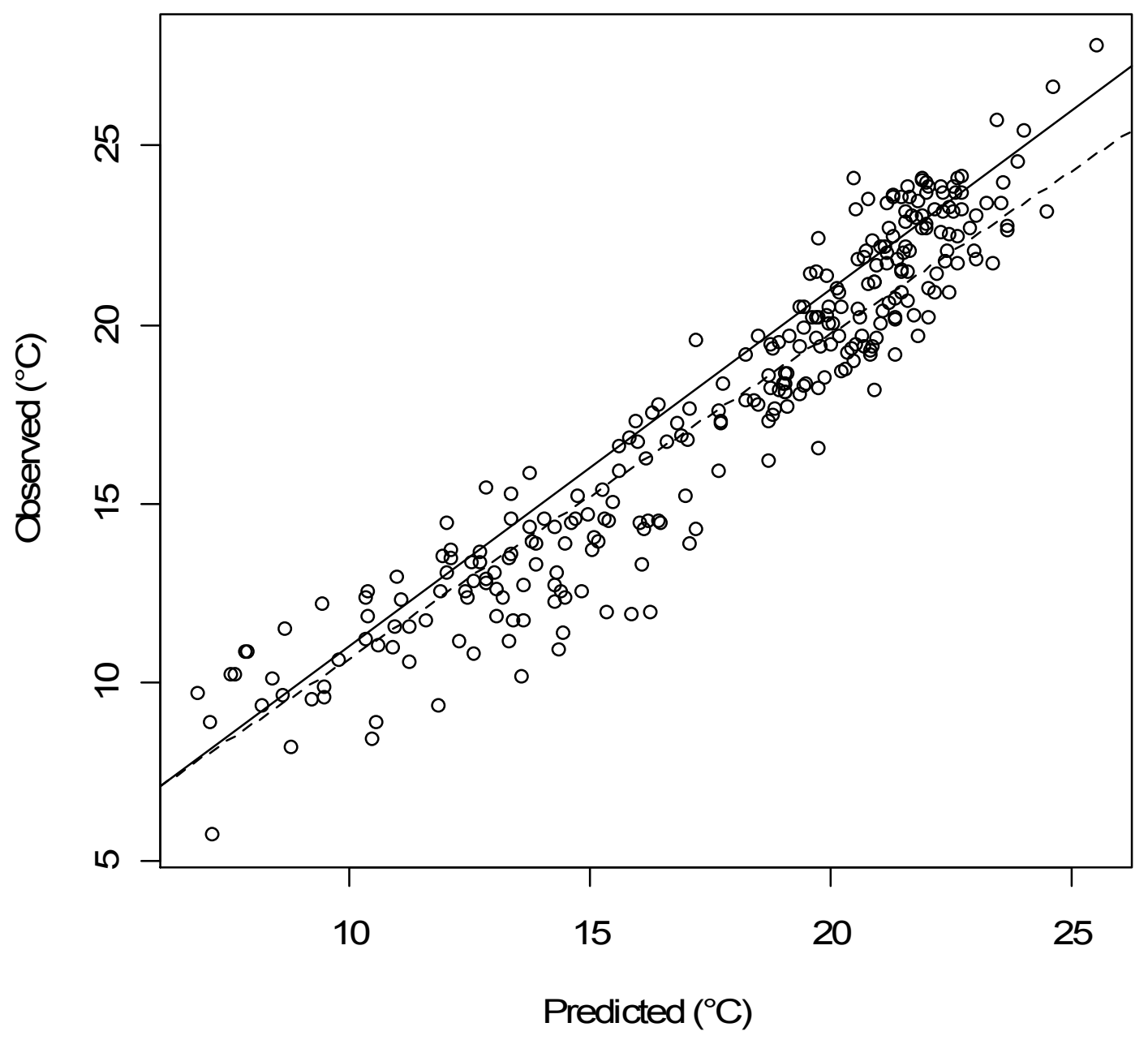

Figure 7. Observed vs. predicted 7 day moving average (7DMA) of maximum water temperature using test data for Shavers $41.1\left(\mathrm{R}^{2}=0.89\right)$, which is a typical mainstem site. Solid line is a 1:1 line. Dashed line is a best fit line. 


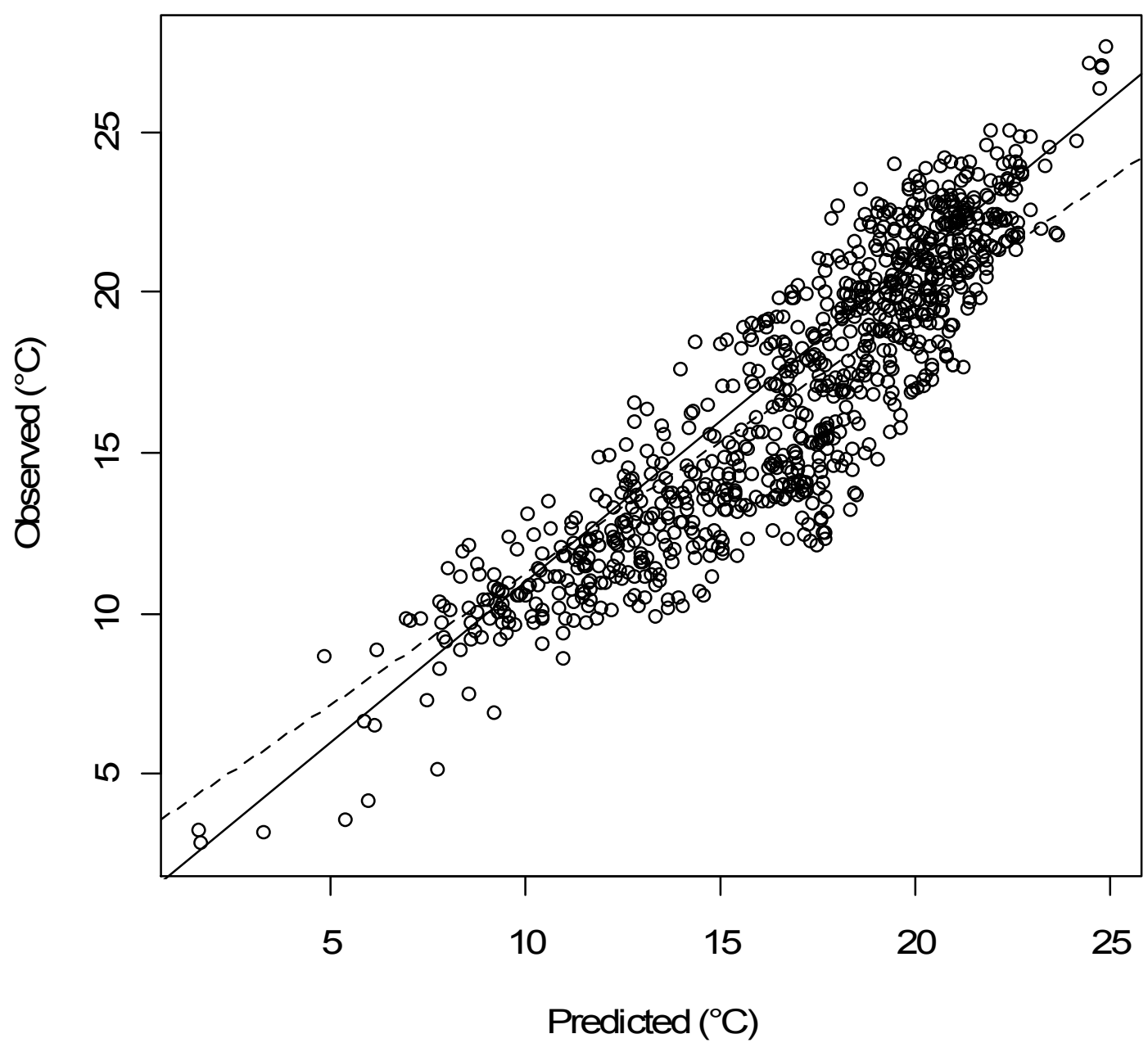

Figure 8. Observed vs. predicted 7 day moving average (7DMA) of maximum water temperature using training data for Shavers $59.4\left(\mathrm{R}^{2}=0.82\right)$, which is the site with the lowest $\mathrm{R}^{2}$ value. Solid line is a 1:1 line. Dashed line is a best fit line. 


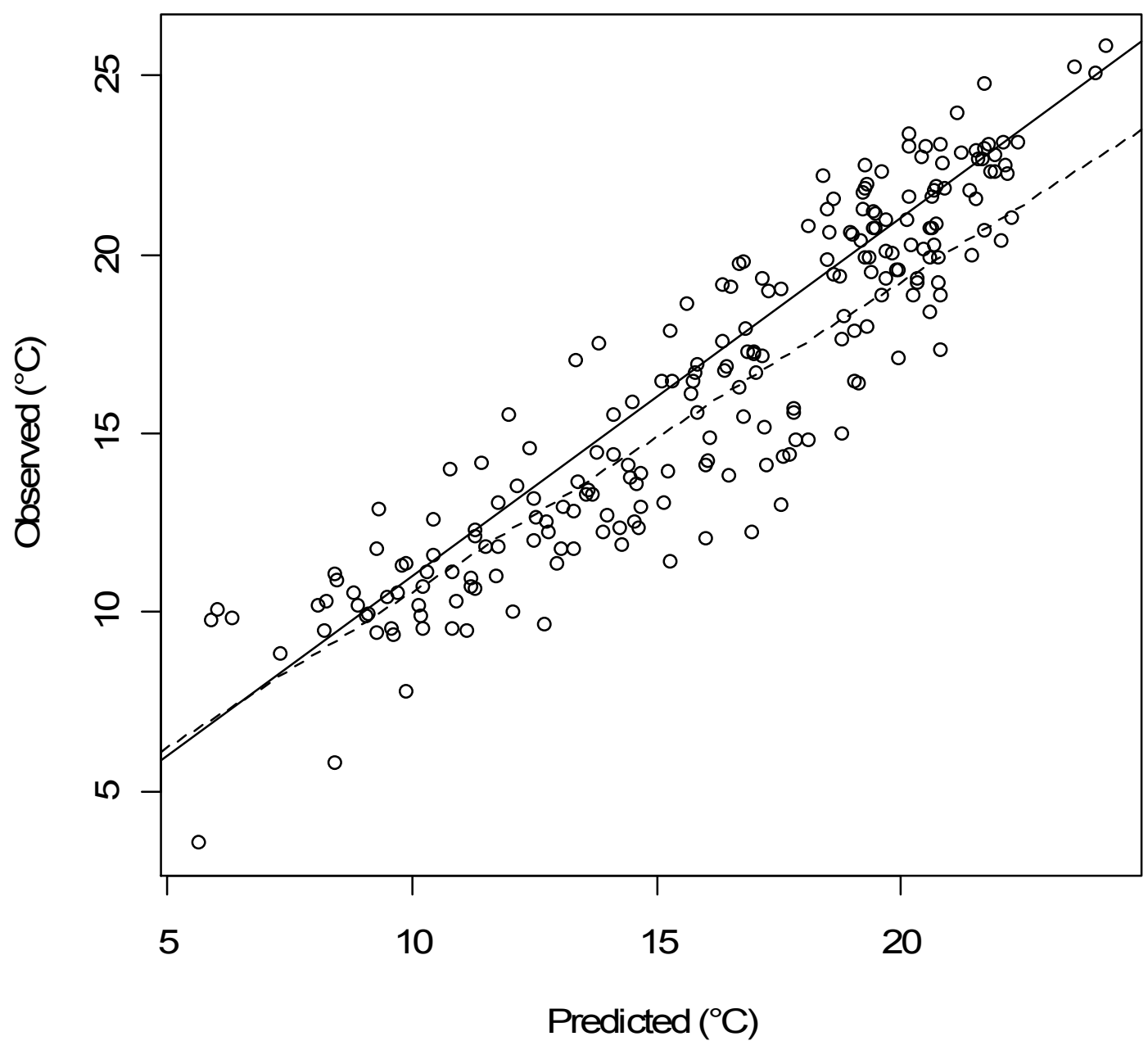

Figure 9. Observed vs. predicted 7 day moving average (7DMA) of maximum water temperature using test data for Shavers $59.4\left(R^{2}=0.84\right)$, which is the site with the lowest $R^{2}$ value. Solid line is a 1:1 line. Dashed line is a best fit line. 


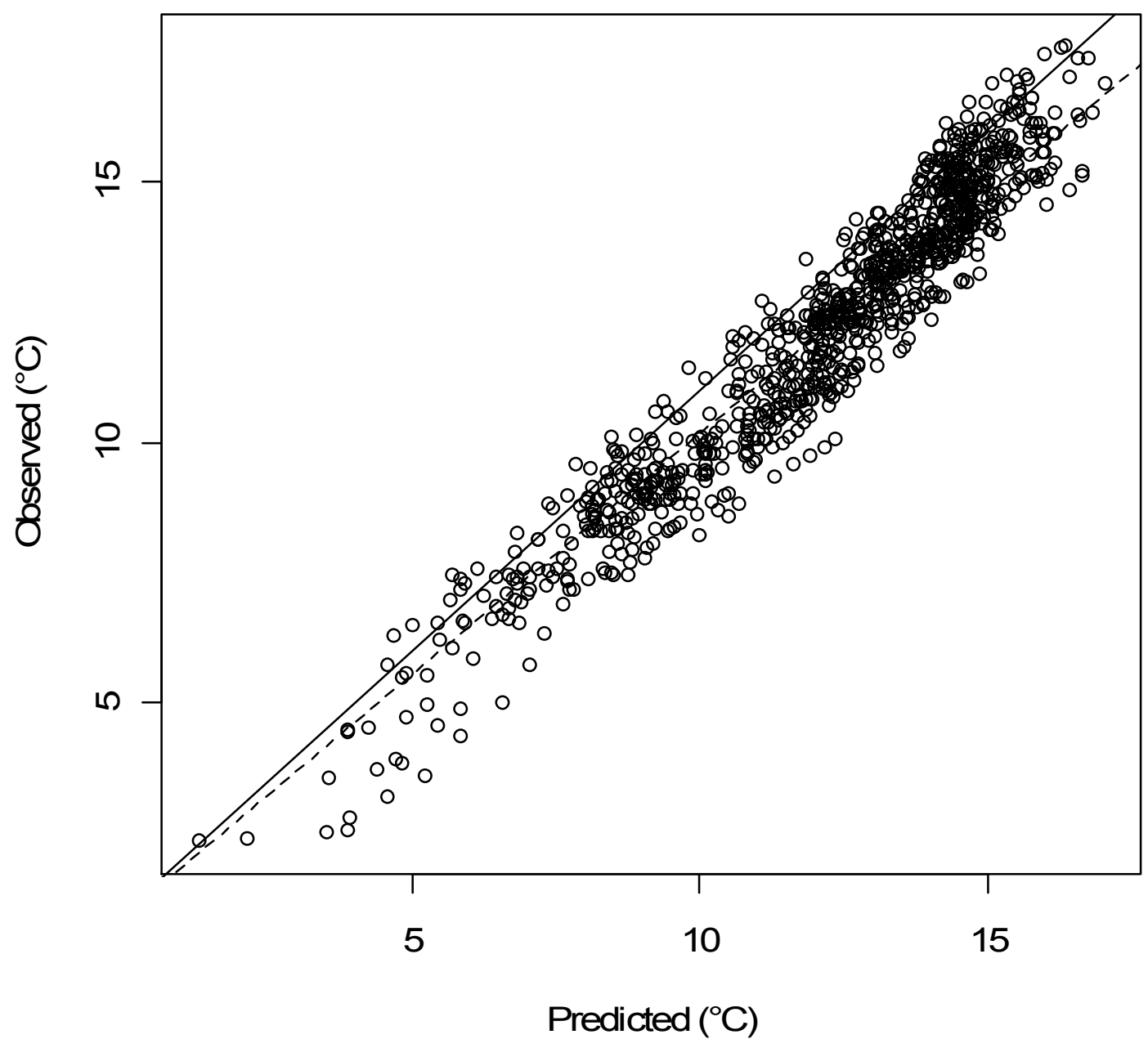

Figure 10. Observed vs. predicted 7 day moving average (7DMA) of maximum water temperature training data for Second 2.1 $\left(\mathrm{R}^{2}=0.93\right)$. Solid line is a 1:1 line. Dashed line is a best fit line. 


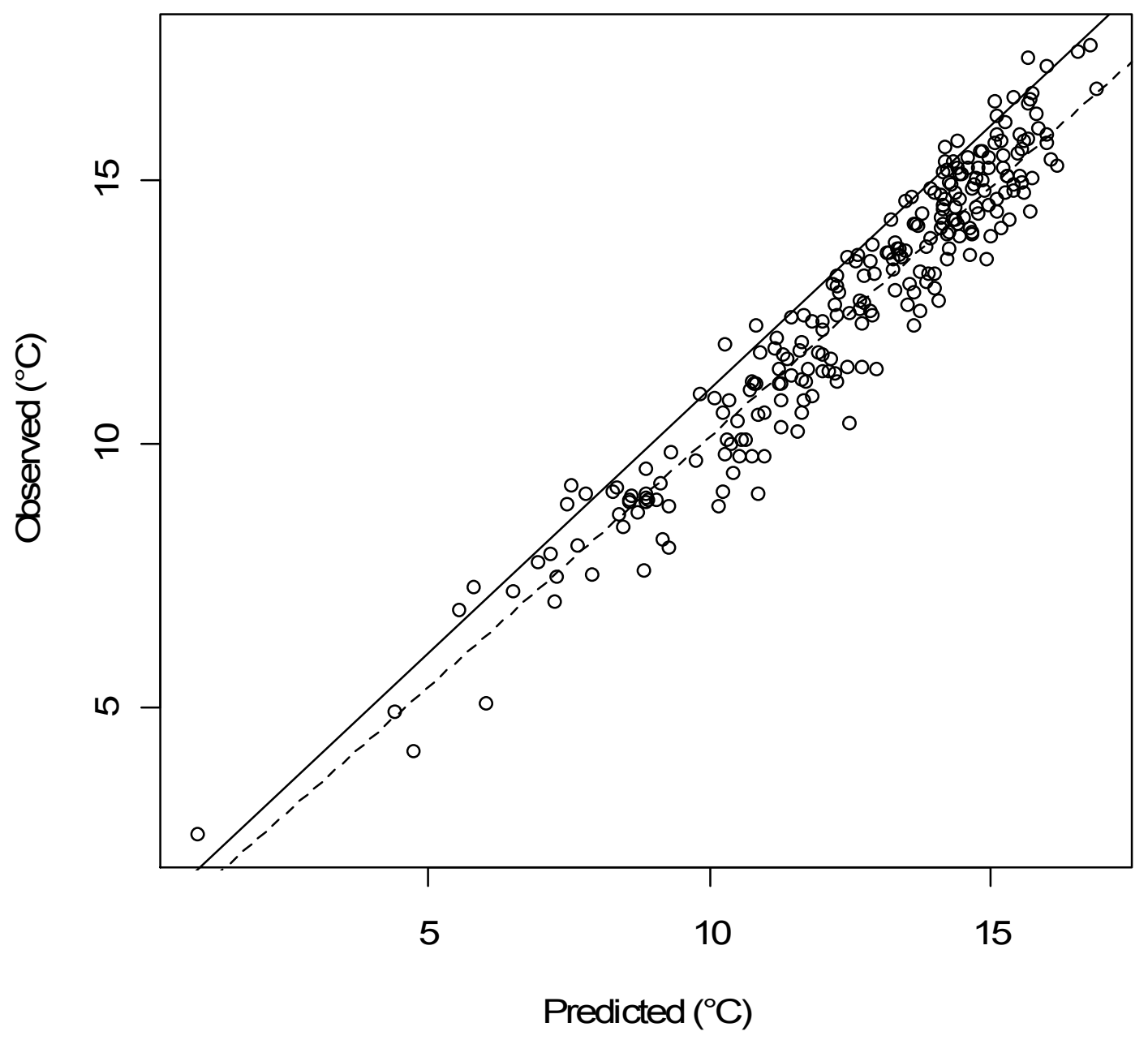

Figure 11. Observed vs. predicted 7 day moving average (7DMA) of maximum water temperature test data for Second $2.1\left(\mathrm{R}^{2}=0.92\right)$. Solid line is a 1:1 line. Dashed line is a best fit line. 


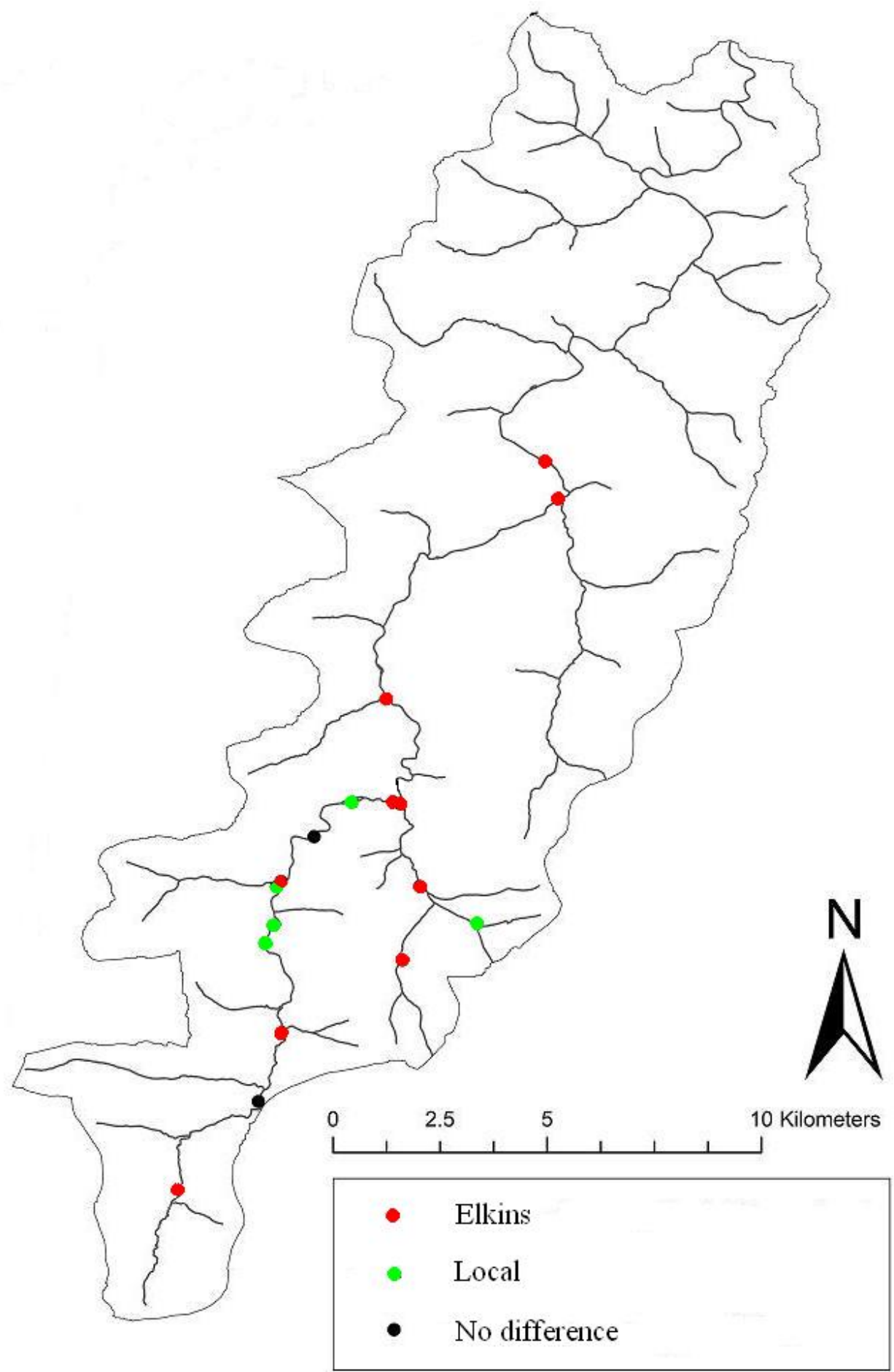

Figure 12. Map displaying whether regional or local air temperature better predicted water temperature. 


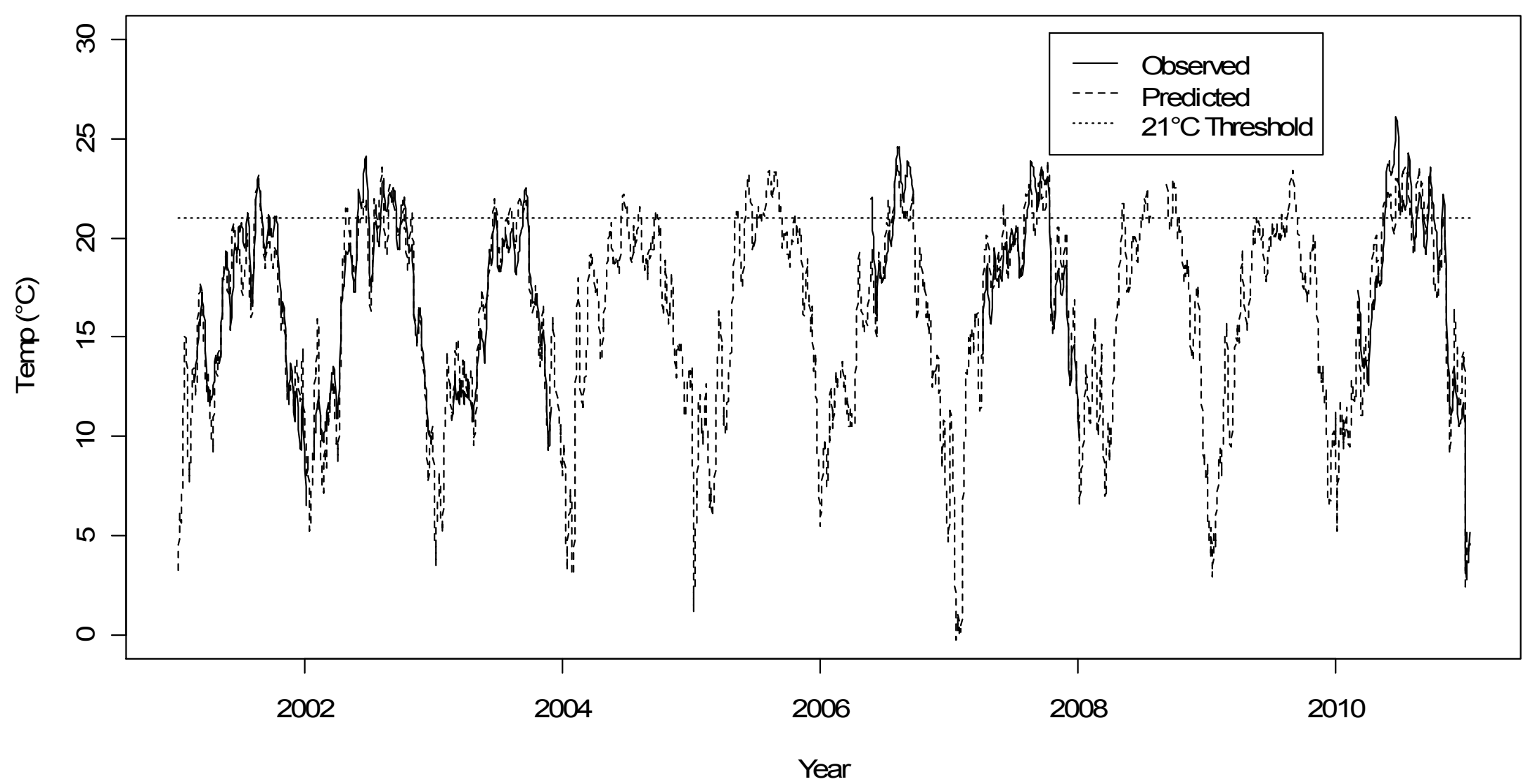

Figure 13. Estimated 7 day moving average (7DMA) of maximum water temperatures from 2001 to 2012 for April - October for Shavers 41.1, which is a typical mainstem site. Observed 7 day moving average (7DMA) of maximum water temperatures have been filled in when available 


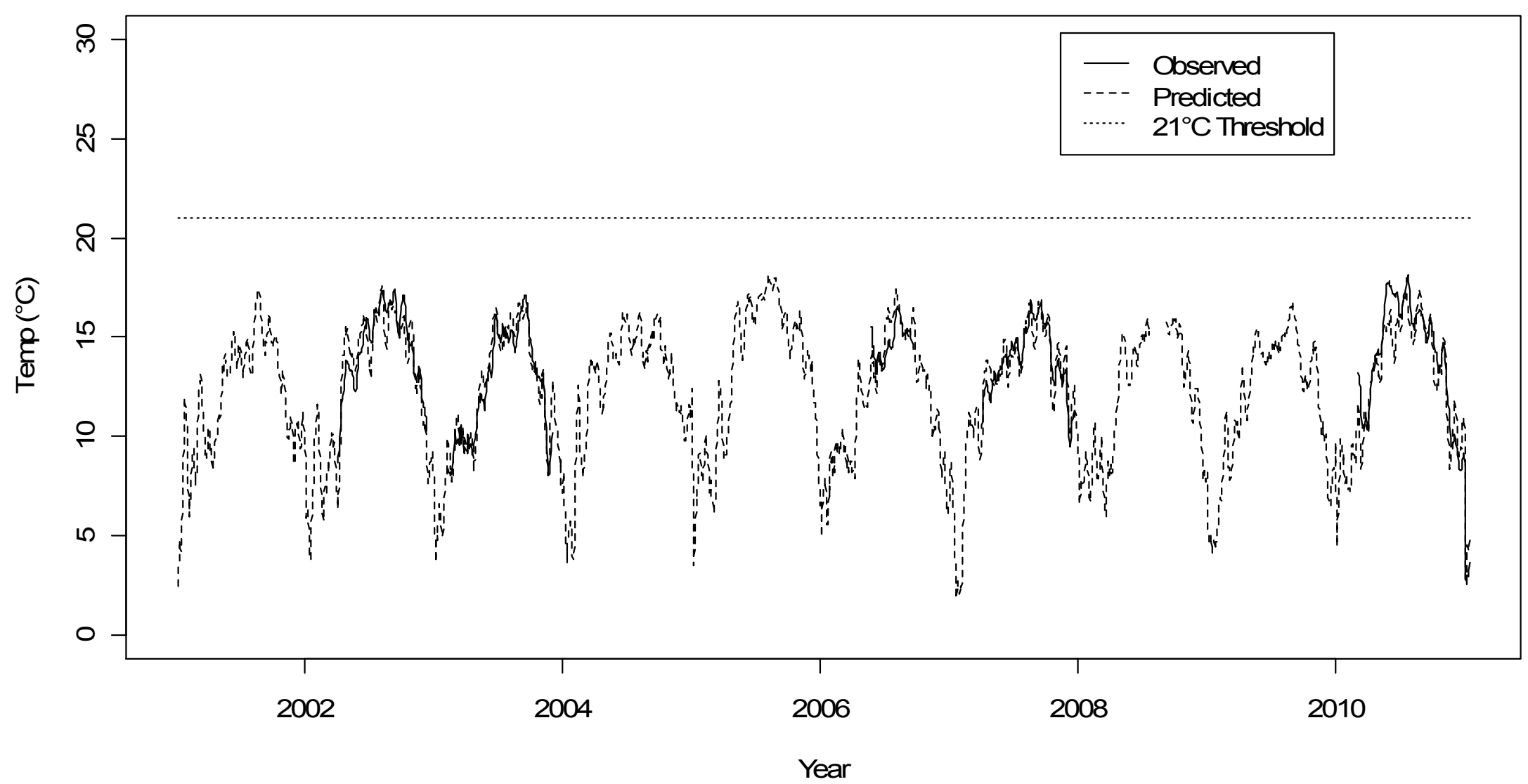

Figure 14. Estimated 7 day moving average (7DMA) of maximum water temperatures from 2001 to 2012 for April - October for Second 2.1, which is a tributary site. Observed 7 day moving average (7DMA) of maximum temperatures have been filled in when available. 


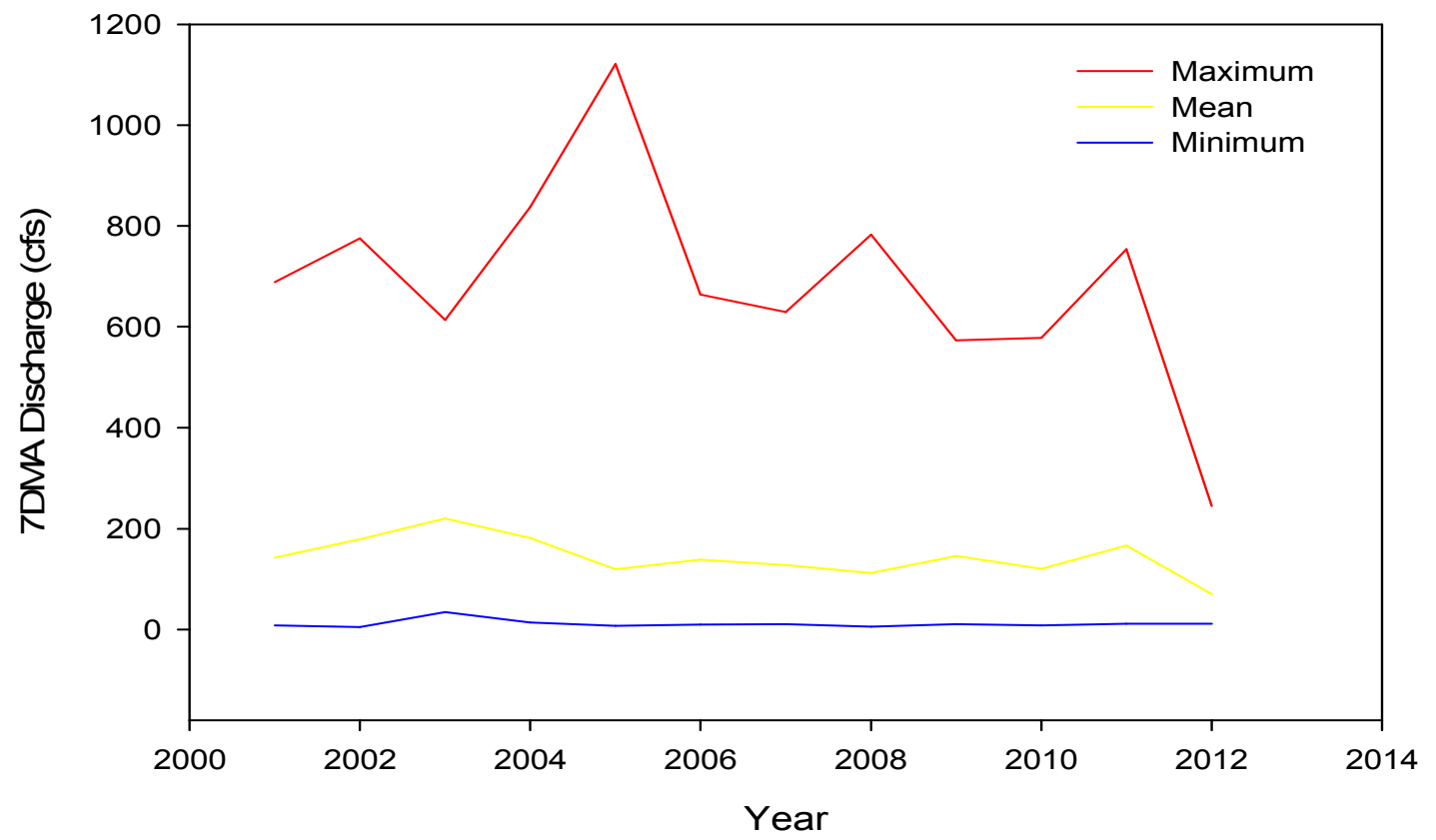

Figure 15. Maximum, mean, and minimum 7 day moving average discharge for 2001-2012. 


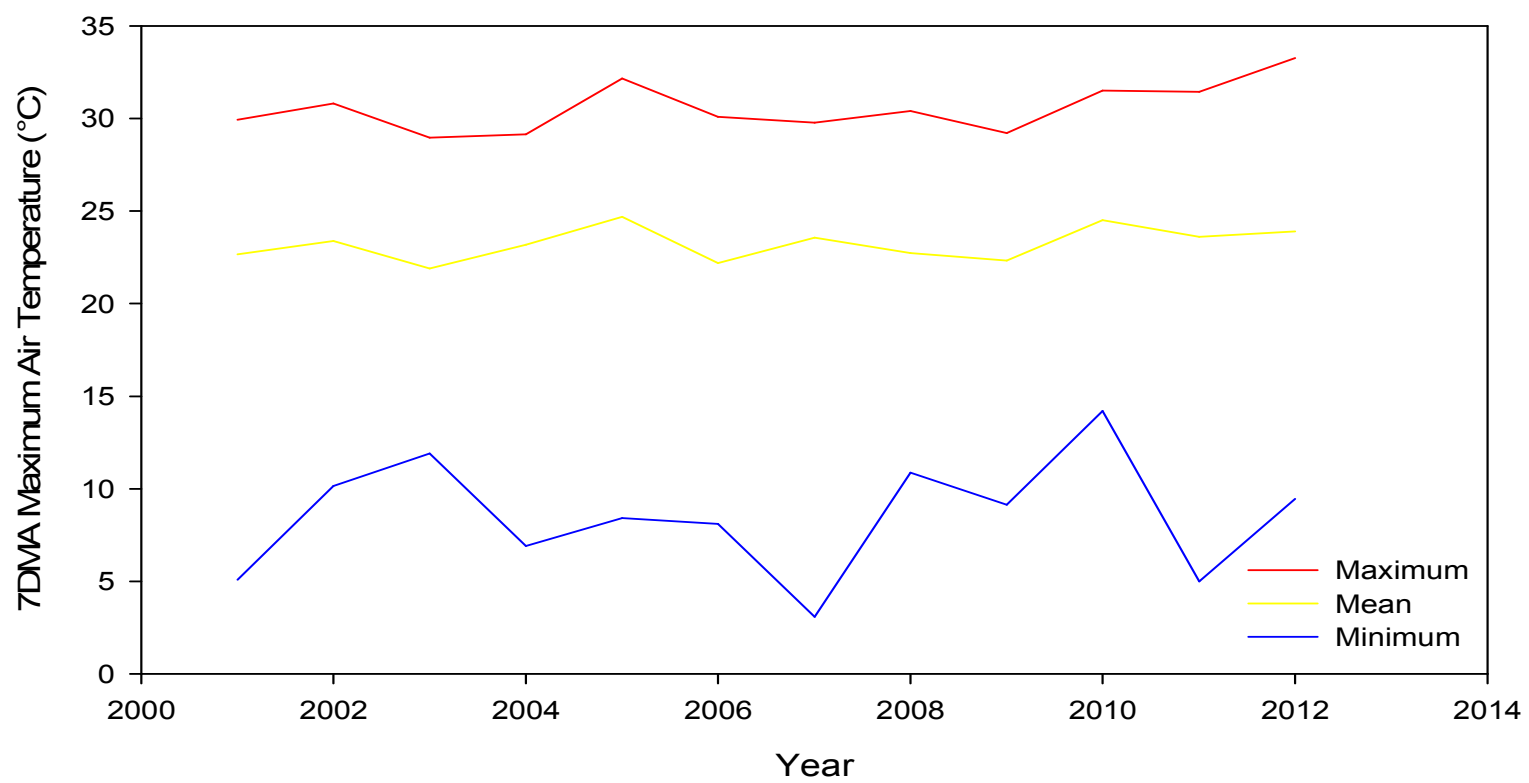

Figure 16. Maximum, mean, and minimum 7 day moving average of maximum Elkins air temperature for 2001-2012. 


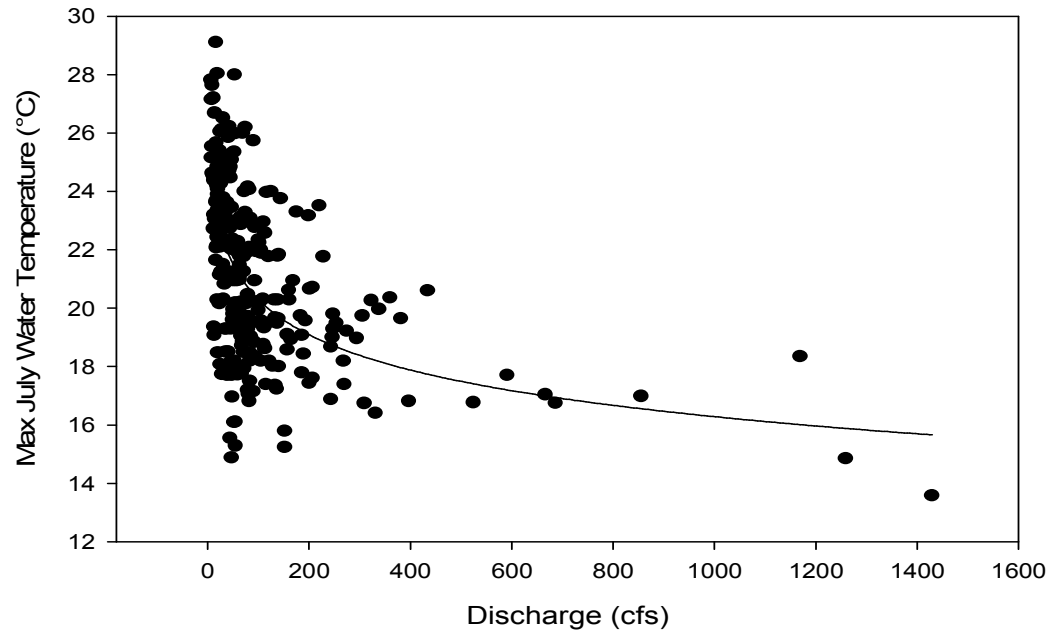

(a)

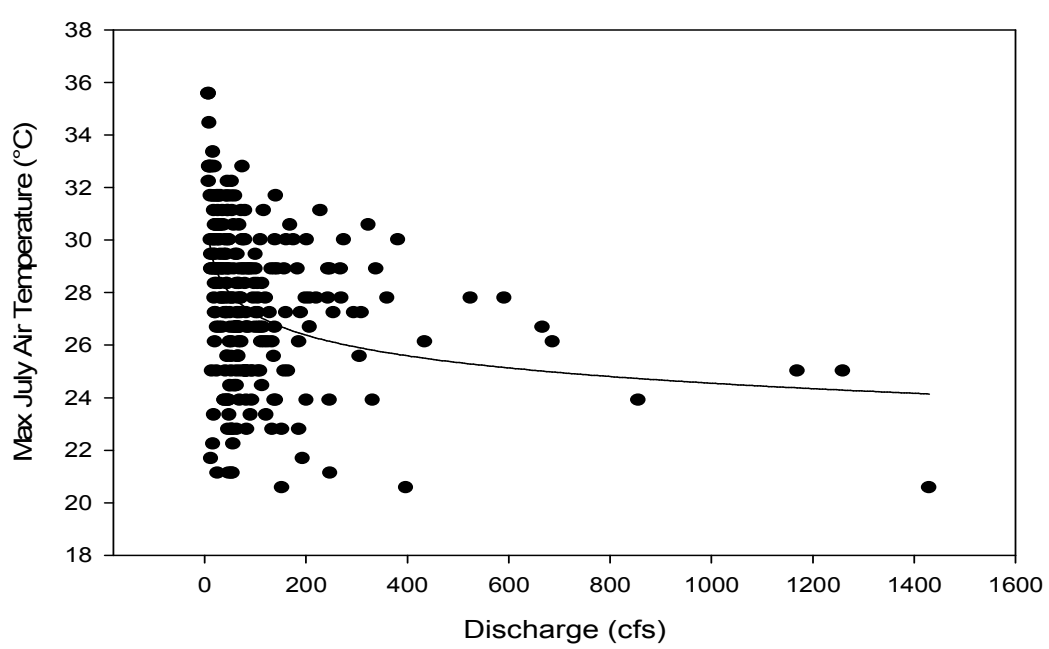

(c)

Figure 17. Correlation between discharge and (a) maximum water temperature $\left(\mathrm{R}^{2}=0.32\right)(\mathrm{b})$ mean water temperature $\left(\mathrm{R}^{2}=0.28\right)$ (c) maximum air temperature $\left(\mathrm{R}^{2}=0.14\right)$ and $(\mathrm{d})$ mean air temperature $\left(\mathrm{R}^{2}=0.02\right)$ in July.

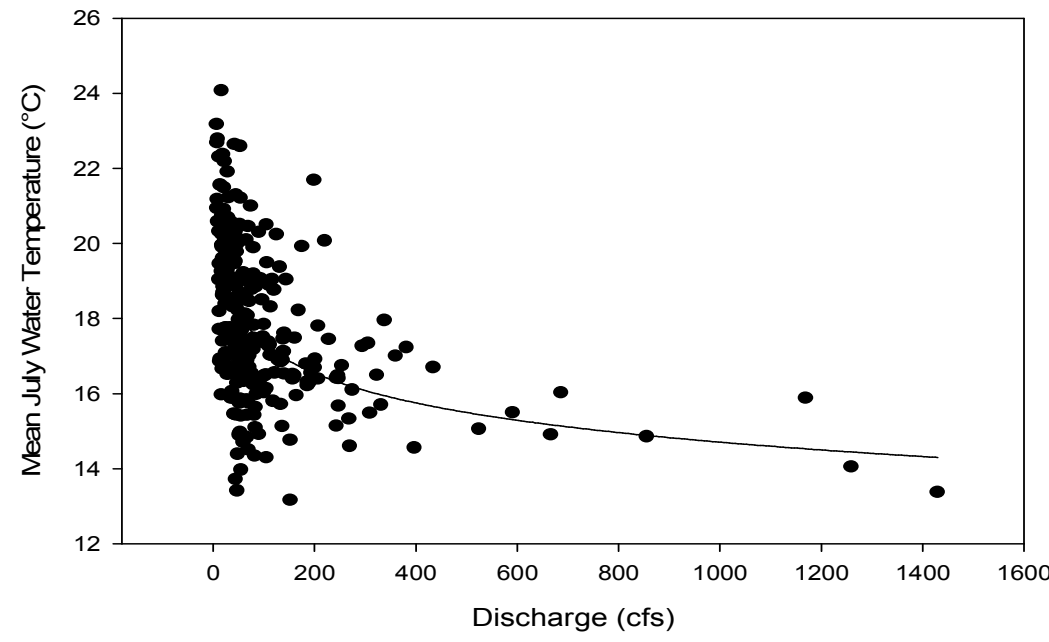

(b)

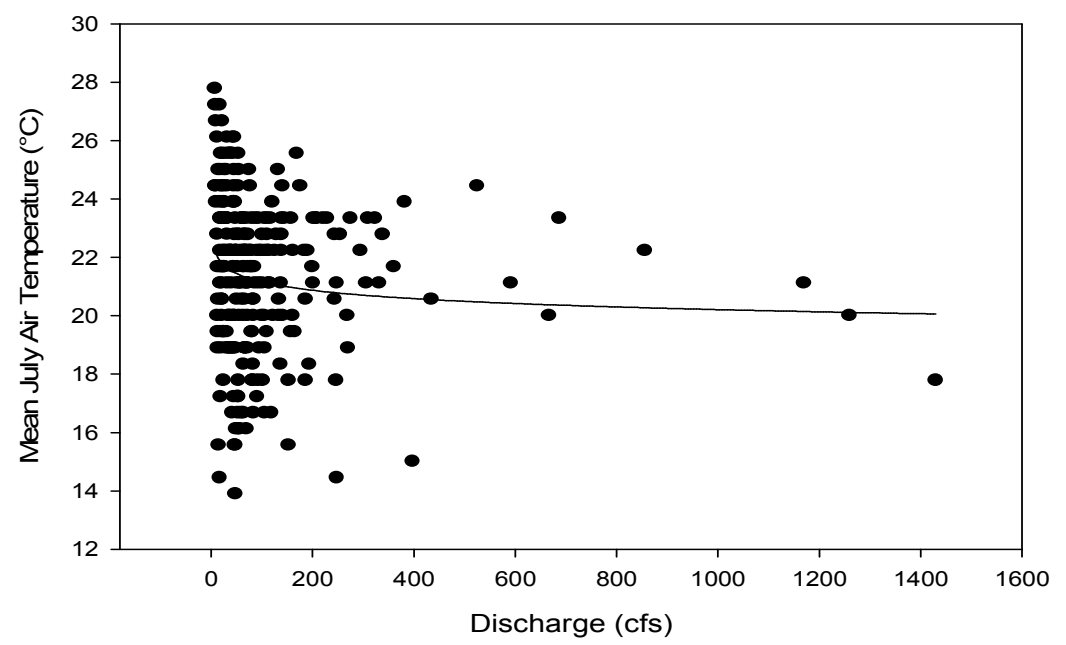

(d) 


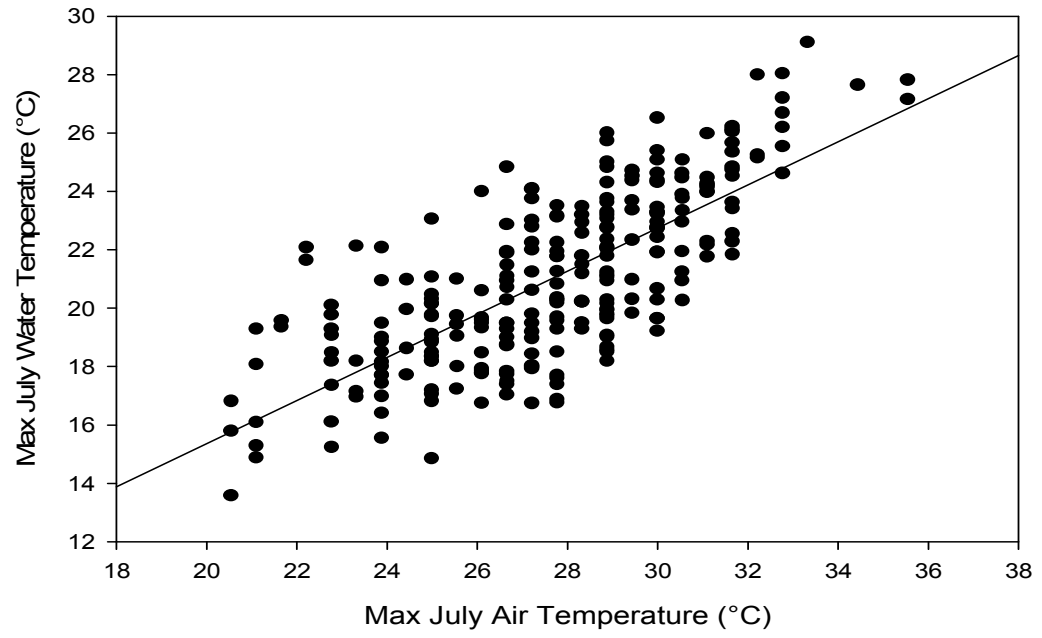

(a)

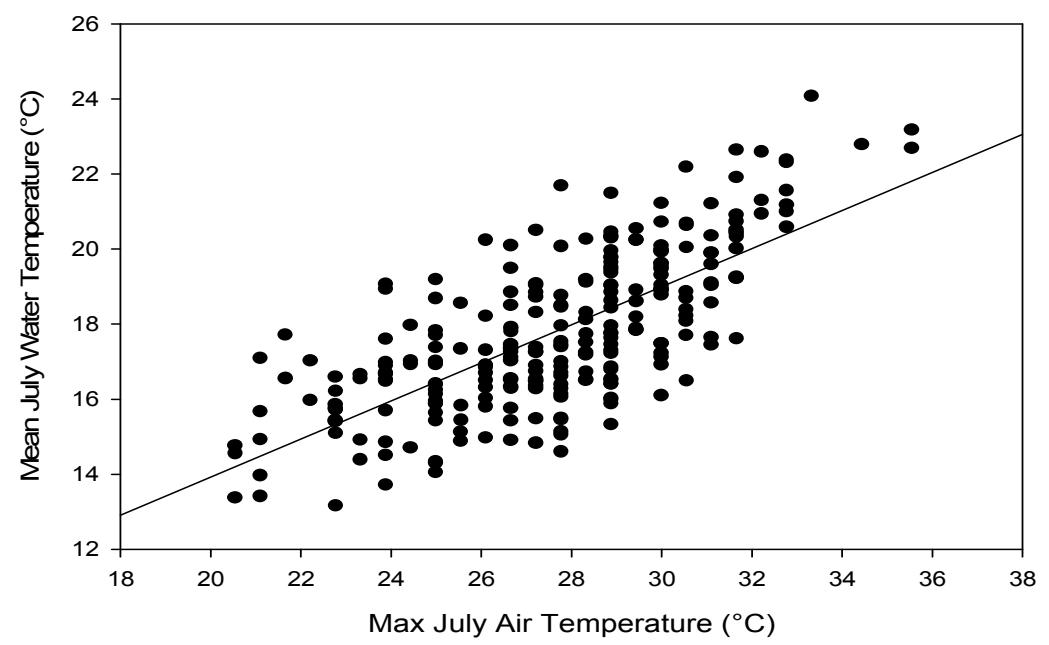

(c)

Figure 18. Correlations between (a) maximum air and maximum water temperatures $\left(R^{2}=0.55\right)(b)$ mean air and mean water temperatures $\left(\mathrm{R}^{2}=0.56\right)$ and $(\mathrm{c})$ maximum air and mean water temperatures $\left(\mathrm{R}^{2}=0.52\right)$ in July.

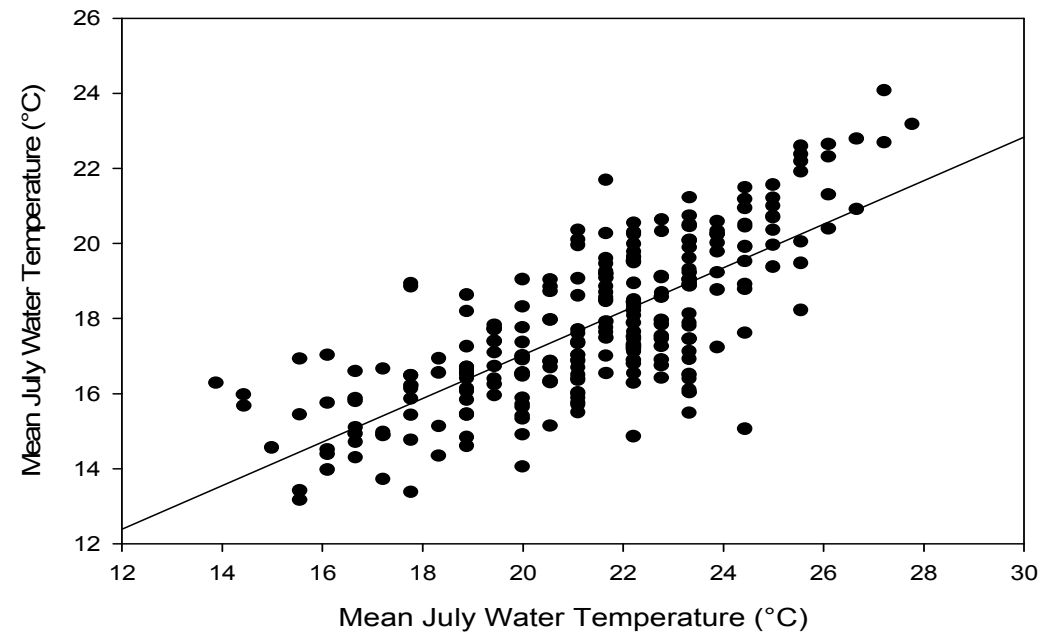

(b) 


\title{
Chapter 2: Assessing habitat quality within the Upper Shavers Fork watershed, WV using a bioenergetics approach
}

\begin{abstract}
Using these water temperature models, we are then able to backcast water temperatures and estimate brook trout growth potential from 2001-present. Brook trout are a vulnerable species to climate change throughout the Appalachians. Therefore, it is important to understand their current growth behavior. The objectives of this study were to (1) determine potential growth patterns in four site types: small tributary, large tributary, cool mainstem, and warm mainstem; (2) assess seasonal variance in growth potential; and (3) determine site and seasons with highest brook trout growth potential. Eight study sites were classified into site types to determine growth potential differences between small tributaries, large tributaries, cool mainstem, and warm mainstem sites. Fish Bioenergetics 3.0 was used to estimate growth and a two ANOVA was used to determine differences between sites and seasons. Results show that small (10 g) adult brook trout growth is maximized in small and large tributaries, whereas large $(50 \mathrm{~g})$ adult brook trout growth is maximized in cool and warm mainstems. Spring was the best season for growth, regardless of fish size or location. CMS and WMS springs were the best site and seasons for growth. Summer had the lowest growth potential for all sites.
\end{abstract}




\section{Introduction}

Modeling spatial and temporal variation in the bioenergetic potential of alternative fish habitats is important to understanding where the best possible locations are for an individual or species and how these may change over time. It can give insight into a species' seasonal migration patterns and potential response to climate change (Bevelhimer and Adams 1993, Brandt 1993, Brönmark et al. 2010, and Beer and Anderson 2011). Brook trout (Salvelinus fontinalis) are a highly studied species throughout the Appalachians because of their importance as a sport fish and declining population size. Over the past century, brook trout populations have declined in the Appalachians due to deforestation, acid precipitation, acid mine drainage, and introduction of non-native species (Marschall and Crowder 1996, Wigington et al. 1996). Understanding the current bioenergetics conditions of brook trout habitats is essential to conserving and restoring this native species.

Brook trout are a coldwater species associated with high elevation headwater streams (Petty et al. 2005). Brook trout have a relatively short life span, as they are rarely found above age-4 in the Appalachians (Stolarski and Hartman 2010). Brook trout require reproductive, foraging, and refuge habitats to successfully grow and survive (Thorne 2004). Spawning occurs in small headwater streams, typically $<3.0 \mathrm{~km}^{2}$ in basin area (Petty et al. 2005). Highly productive mainstem sites, such as upper Shavers Fork, are ideal for foraging, but often have little available cover, no reproductive areas, and may be characterized at times by extremely high water temperatures (Petty et al. 2012).

Fluvial salmonids (i.e., individuals that undergo relatively long distance movements) typically have longer lengths and better fitness than resident individuals of the same age (Stolarski and Hartman 2010). Therefore, it may be beneficial for brook trout to disperse from 
small headwaters where spawning occurs to larger mainstem sites where growth and consumption may be maximized (Thorne 2004, Petty et al., In Review). Mainstem sites are usually associated with better quality food sources than tributaries (Thorne 2004). Fish make up a larger component of brook trout diets (Thorne 2004) and are much more energy dense than other prey resources, such as invertebrates (Jonsson et al. 1999, Thorne 2004). However, mainstem sites also provide greater risks of mortality due to increased water temperatures, predation, and angling pressure. Growth rate of brook trout is highest when water temperature ranges from $13-21^{\circ} \mathrm{C}$ and optimized at $18^{\circ} \mathrm{C}$ (Hartman and Sweka 2001). High summer temperatures can reduce brook trout growth rates (Robinson et al. 2010). Once water temperature rises above $21^{\circ} \mathrm{C}$, they may start to lose weight because of an increased metabolism (Hartman and Sweka 2001), or they may be required to seek out thermal refugia (Petty et al. 2012).

Bioenergetics modeling has become a preferred method for quantifying fish habitat quality, especially when habitats vary with regard to food availability and temperature. Bioenergetics modeling can estimate energy gain in an animal based on its consumption (Winberg 1956). Kitchell et al. (1977) was one of the first to use bioenergetics modeling to estimate growth of an individual fish by simulating growth of yellow perch (Perca flavescens) and walleye (Sander vitreus). More recent applications of bioenergetics modeling have included estimating stocking rates based on available prey and estimating climate change impacts on consumption rates (Chipps and Wahl 2008). There are several salmonid species specific bioenergetics models (Railsback and Rose 1999, Hartman and Sweka 2001, Madenjian et al. 2004). Many studies involving salmonids have revolved around determining effects of forest 
harvest (Leach et al. 2012) and seasonal variation (Railsback and Rose 1999, Thorne 2004, Farley and Trudel 2009) on trout growth.

Bioenergetics are heavily dependent on consumption, respiration rate, temperature, and fish size. Consumption and respiration rate directly affect growth, while temperature and fish size influence consumption and respiration (Kitchell et al. 1977). Food availability also impacts consumption rates (Kitchell et al. 1974). Consumption can vary significantly from season to season (Thorne 2004). In the Appalachians, brook trout generally do not consume as much in summer because of reduced food availability (Sweka and Hartman 2001).

Several studies have used bioenergetics modeling to explain species migration to better quality habitats. Busch et al. (2011) used a bioenergetics model to explain vertical movements in lake fish in response to water temperature. Bioenergetics modeling has also been used to assess habitat quality for fish, with many studies involving salmonids. Farley and Trudel (2009) quantified sockeye salmon (Oncorhynchus nerka) habitat quality based on warm and cool spring temperatures and determined which one was better for growth rate. Habitat quality was assessed based on energetic limitations (Farley and Trudel 2009).

Brook trout are an important fish species in the Appalachians and for various reasons have declined in population over the past century. Understanding habitat quality is essential for the conservation of brook trout. Determining areas that are energetically better than others can help us better understand brook trout migration patterns and aid in stream restoration efforts. Through a study assessing spatial and seasonal variation of brook trout growth potential in the upper Shavers Fork watershed, our specific objectives were to: (1) determine potential growth patterns in small tributaries, large tributaries, cool mainstem and warm mainstem sites; (2) assess 
variance in growth potential across seasons; and (3) determine if spatio-temporal patterns in brook trout growth potential differ between small $(10 \mathrm{~g})$ and large $(50 \mathrm{~g})$ individuals.

\section{Methods}

Fish Bioenergetics 3.0 software was used to estimate growth potential of brook trout (Hanson et al. 1997). Hartman and Sweka (2001) originally developed a brook trout bioenergetics model. An updated version of their original model with more accurate parameters was later developed (Hartman and Cox 2008). Validations of the updated model indicate modeled growth rates are typically within $12.5 \%$ of actual growth (Hartman and Cox 2008). Mean daily brook trout consumption was obtained from Thorne (2004) and averaged across all seasons for each site type. The average daily consumption was multiplied by the number of days (214) analyzed each year to determine the amount consumed. Proportion of brook trout diet by weight was obtained from Thorne (2004) and averaged across all seasons for each site type. Consumption amount and diet proportion were assumed to remain the same for each site throughout the study. Prey energetic values were acquired from Cummins and Wuycheck (1971). Mean daily temperature from 2001-2012 was estimated from climate-water temperature models constructed in Chapter 1.

There were 18 different study sites analyzed (Table 1, Figure 1). Four different site types were created using 2 sites per site type $(\mathrm{N}=8)$. Site types included small tributaries $(\mathrm{ST})$, large tributaries (LT), cool mainstem (CMS), and warm mainstem (WMS). Each site type had varying water temperatures (Table 2). Shavers 27.9 and Shavers 29.5 were selected for the CMS site type and Shavers 43.8 and Shavers 89.1 were selected for the WMS site type. Simulations were performed each year from 2001-2012 for small adult brook trout and large adult brook trout 
across these different sites using site specific temperature. Water temperature was not able to be backcast for 2008 and 2011 because discharge was not available for a portion of the time.

Growth potential for 2008 and 2011 were therefore not estimated. Small adult brook trout were assigned a starting weight of $10 \mathrm{~g}$ for each simulation, while large adult trout starting weight was 50g. Small adult brook trout are typically $60-115 \mathrm{~mm}$ in length (Petty et al. 2005) and a $10 \mathrm{~g}$ fish in this watershed fits within that frame $(\sim 90 \mathrm{~mm}$, Petty unpublished data). Large adult brook trout starting weight was assigned by averaging the weight of all brook trout $>115 \mathrm{~mm}$ (Petty unpublished data).

Each modeled year began on April 1 and ended October 31 for a total of 214 days each year. The streams in this watershed are typically not frozen during this time and allow for accurate water temperature modeling. Each model was simulated for one year and separated into one of three seasons based on day. Spring ranged from April 1 to May 31 (day 1-61), summer ranged from June 1 to July 31 (day 62-122), and fall ranged from August 1-October 31 (day 123214). Seasons were based on Thorne (2004) seasonal growth rate sampling.

A two-way ANOVA was performed to determine if season and site type influenced growth potential for both fish sizes. If there was a significant difference $(\mathrm{P}<0.05)$, then a Tukey's test was used to identify pairwise differences. Linear regressions were used to relate seasonal growth rate to annual growth rate. Linear regressions were also used to determine if water temperature and discharge were correlated with annual growth rates.

\section{Results}

For a $10 \mathrm{~g}$ brook trout, growth was highest in Second 2.1, Second 3.4, and Second 10.4, with average annual net growth estimated at $16.1 \mathrm{~g}, 15.4 \mathrm{~g}$, and $15.6 \mathrm{~g}$, respectively (Table 3 , 
Figure 2). Shavers 12.9 also had a high growth potential for small trout, with an annual net growth of 15.0g. Sites with lowest net growth for small trout included Shavers 43.8 and Shavers 89.1. These sites averaged a loss in weight of $1.2 \mathrm{~g}$ and $1.0 \mathrm{~g}$, respectively.

Small and large tributaries had high potential net growth for small trout (Figure 3). Small and large tributaries' growth averaged $5.8 \mathrm{~g}$ and $4.1 \mathrm{~g}$, respectively. Growth of small trout in cool mainstem sites averaged $1.2 \mathrm{~g}$, while warm mainstem sites averaged a decline by $1.1 \mathrm{~g}$. Spring had the highest growth rate for all four site types across all seasons (Figure 4). Cool mainstem and warm mainstem had the highest spring growth potentials with $8.2 \mathrm{~g}$ and $8.4 \mathrm{~g}$, respectively. Large tributaries had an estimated growth of $5.2 \mathrm{~g}$, while small tributaries were estimated at $4.3 \mathrm{~g}$. Warm mainstem spring growth was the highest net growth potential of all sites and seasons. In summer, however, small adult brook trout typically decreased in weight. Small tributaries averaged a growth of $0.3 \mathrm{~g}$. Large tributaries averaged a decline of $1.2 \mathrm{~g}$. In the cool and warm mainstems, net growth potential was estimated to decrease $5.6 \mathrm{~g}$ and $7.6 \mathrm{~g}$, respectively. There were also decreases in weight during the fall for cool and warm mainstems. Net potential growth was $-1.3 \mathrm{~g}$ and $-1.9 \mathrm{~g}$, respectively. Large tributaries had a net potential growth of $0.2 \mathrm{~g}$, while small tributaries had a net growth potential of $1.1 \mathrm{~g}$.

One of the better years for growth potential of a $10 \mathrm{~g}$ brook trout was 2009 (Table 4, Figure 5). Growth was 7.4, 6.2, 3.4, and 0.0 for ST, LT, CMS, and WMS, respectively. One of the worst net growth potential years was 2005 . Net growth was estimated as $2.5,-0.7,-3.3$, and 5.4 for ST, LT, CMS, and WMS, respectively. There were two time frames during 2005 and 2009 where growth differed. The first was mid-July through August (late summer into early fall), while the second was the beginning of October (late fall) (Figure 6). During these times, temperatures were cooler in the good growth year (Figure 7). 
Two way ANOVA shows there was a significant difference between sites, seasons, and site*season for a $10 \mathrm{~g}$ brook trout (Table 5). Tukey's tests showed there was a difference between LT-WMS, ST-WMS, and ST-CMS site types $(\mathrm{p}<0.05)($ Table 6). Large tributaries and small tributaries had significantly higher potential growth than warm mainstem sites. Small tributaries also had significantly higher growth potential than cool mainstem sites. There was a significant difference between all seasonal interactions $(\mathrm{p}<0.05)($ Table 7$)$. Spring was statistically the best season and summer the worst season for a $10 \mathrm{~g}$ brook trout growth.

Linear regressions showed there was little correlation between spring and annual growth for a $10 \mathrm{~g}$ brook trout in each site type $\left(\mathrm{R}^{2}=0.04-0.22\right)$ (Figure 8$)$. There was a positive relation between summer and annual growth in each site type $\left(\mathrm{R}^{2}=0.43-0.59\right)$ (Figure 9). Fall and annual growth displayed a slight positive correlation, as well $\left(\mathrm{R}^{2}=0.28-0.45\right)$ (Figure 10$)$. Spring and summer growth had little negative correlation $\left(\mathrm{R}^{2}=0.19-0.44\right)$ (Figure 11), whereas spring-fall and summer-fall had minimal correlations.

Annual water temperature had a strong negative correlation with $10 \mathrm{~g}$ brook trout growth in small and large tributaries $\left(\mathrm{R}^{2}=0.83\right)$ (Figure 12). Annual water temperature had a negative correlation with $10 \mathrm{~g}$ fish growth in cool and warm mainstem sites $\left(\mathrm{R}^{2}=0.68\right)$ (Figure 13). Spring water temperature and spring growth had minimal negative correlations for each site type $\left(\mathrm{R}^{2}=0.05-0.14\right)$ (Figure 14). There were strong negative correlations between summer temperature and summer growth for all site types $\left(\mathrm{R}^{2}=0.78-0.96\right)($ Figure 15). There were strong negative correlations for fall water temperature and fall growth for ST $\left(\mathrm{R}^{2}=0.86\right)$ and LT $\left(\mathrm{R}^{2}=0.76\right)$, but only slight negative correlations for CMS $\left(\mathrm{R}^{2}=0.45\right)$ and WMS $\left(\mathrm{R}^{2}=0.38\right)$ (Figure 16). 
On average, Shavers 12.9, a mainstem site, had the highest annual growth potential for a $50 \mathrm{~g}$ brook trout (Table 8, Figure 17). Net growth for a 50g brook trout at this site averaged 22.9g. The worst site was Second 3.4, a small tributary site. Net growth by large trout in this site declined by $15.9 \mathrm{~g}$ on average. All small and large tributary sites were estimated to cause weight loss in $50 \mathrm{~g}$ brook trout. The worst mainstem site was Shavers 43.8 , with a growth potential of $5.4 \mathrm{~g}$.

Cool mainstem sites had the highest annual net growth potential out of all site types (Figure 18). Annual net growth averaged 42.5g for CMS and 28.1g for WMS. There were reductions in weight of $32.3 \mathrm{~g}$ and $15.9 \mathrm{~g}$ estimated for ST and LT, respectively. The highest growth occurred in spring for all 4 site types (Figure 19). Cool mainstem, warm mainstem, and large tributaries had growth potentials of $34.8 \mathrm{~g}, 35.2 \mathrm{~g}$, and $8.2 \mathrm{~g}$, respectively. Small tributaries were estimated to decrease brook trout weight by $0.7 \mathrm{~g}$. Spring WMS had the highest net growth out of all site types and seasons. No season showed positive growth in small tributaries. Large tributaries only had a positive growth in spring. No sites had a positive growth in summer, however CMS and WMS were the only sites with positive growth in the fall.

One of the better years for annual growth of a 50g brook trout occurred in 2006. Net annual growth was 55.1g and 36.5g for CMS and WMS, respectively (Table 9, Figure 20). Large and small tributaries' annual growth potentials were estimated to be some of the least reduced for 2006. Brook trout weight was estimated to decrease by $28.6 \mathrm{~g}$ for ST and $9.7 \mathrm{~g}$ for LT. Lowest growth potential occurred in 2005. Net growth potential was 17.7g for CMS and 3.3 for WMS. Large and small tributaries had their biggest weight reductions. Net growth was estimated to decline by $37.0 \mathrm{~g}$ and $27.6 \mathrm{~g}$ for ST and LT, respectively. There were two time frames during 2005 and 2009 where growth differed for a 50g brook trout. The first was mid- 
June through mid-July (middle of summer), and the second was from mid-September to midOctober (mid-late fall) (Figure 21). Temperatures were cooler during these times in the good growth year (Figure 22).

Two way ANOVA for a 50g brook trout showed there were significant differences between sites, seasons, and site*season (Table 10). Tukey's test indicated statistical differences between all possible site type interactions $(\mathrm{p}<0.05)$ (Table 11). Cool mainstem sites were statistically the best for growth, while small tributaries were the worst. Tukey's test also showed a significant difference between all seasons $(\mathrm{p}<0.05)$ (Table 12). Spring was the best season for potential growth, while summer was the worst.

Linear regressions showed minimal negative relation between spring growth and annual growth for a $50 \mathrm{~g}$ brook trout for each site type $\left(\mathrm{R}^{2}=0.00-0.07\right)$ (Figure 23). Summer and annual growth displayed a positive correlation for all site types $\left(\mathrm{R}^{2}=0.45-0.68\right)$ (Figure 24). Fall and annual growth had minimal correlation for ST $\left(\mathrm{R}^{2}=0.02\right)$ and LT $\left(\mathrm{R}^{2}=0.17\right)$, but there was negative correlation for CMS $\left(\mathrm{R}^{2}=0.48\right)$ and WMS $\left(\mathrm{R}^{2}=0.53\right)$ (Figure 25). Spring and fall growth for a $50 \mathrm{~g}$ brook trout had a minimal negative relation for each site type $\left(\mathrm{R}^{2}=0.14-0.20\right)$ (Figure 26). Other seasonal combinations were not as correlated.

Annual water temperature had a strong negative correlation with 50g brook trout growth in ST and LT sites $\left(\mathrm{R}^{2}=0.92\right)$ (Figure 27). Also, annual water temperature had a negative correlation with growth in CMS and WMS sites $\left(\mathrm{R}^{2}=0.79\right)$ (Figure 28). There was a negative correlation between spring growth and spring water temperature $\left(\mathrm{R}^{2}=0.59\right)$ in ST, and a minimal negative correlation for other site types $\left(\mathrm{R}^{2}=0.07-0.21\right)$ (Figure 29). Summer growth and summer water temperature showed strong negative correlations among all site types $\left(\mathrm{R}^{2}=\right.$ 0.91-0.96) (Figure 30). Fall growth and fall water temperature showed a negative correlation 
with all site types, but small tributaries $\left(\mathrm{R}^{2}=0.47\right)$ were noticeably not as correlated as the other site types $\left(\mathrm{R}^{2}=0.63-0.71\right)$ (Figure 31$)$.

\section{Discussion}

There were specific sites across the upper Shavers Fork watershed that were better than others. For a 10g brook trout, Second 2.1, Second 3.4, and Second 10.4 had the highest growth potential on average. These sites had slightly cooler water temperatures compared to Second 15.4 and significantly cooler water temperatures than all mainstem sites. Many mainstem sites had relatively little growth for annual growth potential. Shavers 12.9 had the highest potential growth out of all mainstem sites and was one of the coolest in the mainstem. Shavers 12.9 is one of the smaller mainstem sites and has a well developed canopy cover, which could cause it to have lower water temperatures. Shavers 43.8 and Shavers 89.1 were the worst sites for potential growth. These sites also had the highest average temperatures, which is likely the cause for negative growth. Shavers 43.8 has a shallow streambed and little canopy cover. Shavers 89.1 is further downstream, has little canopy cover, and does not have any significant cold water sources nearby.

The largest annual growth potential for a $10 \mathrm{~g}$ brook trout was in small tributaries. Mean daily consumption was identical in small and large tributaries for small adult brook trout, while mainstem sites had a higher mean daily consumption (Thorne 2004). Although large tributaries have higher quality food, growth was likely better in small tributaries because of the slightly cooler water temperatures. Small adult brook trout consume higher quality food in the mainstem than tributaries (Thorne 2004), but growth potential in tributaries is higher than the mainstem. Food availability and stream temperatures are likely factors for this pattern. Food availability is 
reduced during the summer (Sweka and Hartman 2001). Stream temperatures exceed optimal ranges for brook trout growth, particularly during the summer (Chapter 1). Metabolism is also higher in smaller brook trout than larger fish (Cox and Hartman 2008). A relatively high metabolism due to fish size, coupled with an increased metabolism from high stream temperatures, and inability to consume sufficient amounts of food to cover these metabolic costs are potential reasons for mainstem growth potential being lower than large tributaries. This also helps explain the large reduction in weight during the summer for brook trout in the mainstem.

For a $50 \mathrm{~g}$ brook trout, Shavers 12.9 was the best site for growth potential. Shavers 43.8 and Shavers 89.1 were usually the worst mainstem sites because of their increased water temperatures. All small and large tributaries had negative growth potential on average. Limited food availability is the most likely reason for the $50 \mathrm{~g}$ brook trout not being able to sustain growth in tributaries.

The highest annual growth potential for a 50g brook trout occurred in cool and warm mainstem sites when compared to small and large tributary sites. Mean daily consumption for large adult brook trout are nearly three times higher in the mainstem than tributaries (Thorne 2004). Mainstem sites also have higher quality food than tributaries for large adult brook trout. Fish made up a larger proportion of the diet for large brook trout in the mainstem than tributaries. Consuming fish is beneficial because they are energetically valuable and increase growth rates and body size (Jonsson et al. 1999). Also, larger brook trout do not have as high of a metabolism as smaller brook trout (Hartman and Cox 2008). The significantly larger consumption rates and quality food, coupled with lower metabolic demands, assist the mainstem in being a better location for $50 \mathrm{~g}$ brook trout growth. Cooler water temperatures are the reason cool mainstem 
sites had higher growth potential than warm mainstem sites. Cool mainstem sites remained in the optimal temperature growth range more than warm mainstem sites.

Spring had the largest growth potential of all seasons for $10 \mathrm{~g}$ and $50 \mathrm{~g}$ brook trout, while summer had the lowest. Cooler spring temperatures allow brook trout to grow, while increasing temperatures in summer slow or even reduce growth. Railsback and Rose (1999) found that growth rates were lowest in summer for rainbow trout (Oncorhynchus mykiss) and attributed it to not consuming enough to meet metabolic demands. Cool and warm mainstem springs were the best sites and season for growth potential for $10 \mathrm{~g}$ and $50 \mathrm{~g}$ brook trout. This is likely due to favorable temperature conditions in spring and high availability of quality food in the mainstem. Cool and warm mainstem summers had the lowest growth potentials for $10 \mathrm{~g}$ brook trout. This could be attributed to increased metabolism due to size (Cox and Hartman 2008), warmer stream temperatures, and reduced food availability (Sweka and Hartman 2001). Small tributary summer had the lowest growth potential for a $50 \mathrm{~g}$ brook trout. This is likely due to limited food availability in small tributary sites for large adult brook trout.

Other bioenergetics studies have shown daily and seasonal variance in growth. Budy et al. (2011) showed differences in growth potential daily and seasonally for three different fish species. Two coolwater species, black crappie (Pomoxis nigromaculatus) and walleye (Sander vitreus), had similar growth patterns as the coldwater brook trout. Their highest growth period was in the spring, followed by a smaller peak period in the fall. Warmwater species tend to not follow this pattern. Channel catfish (Ictalurus punctatus) were shown to have highest growth potential during the summer. Dauwalter and Fisher (2008) also found that smallmouth bass (Micropterus dolomieu) had highest growth during the summer and lowest in spring. 
Surprisingly, there was minimal correlation between spring growth and annual growth for both sizes of brook trout. High spring growth did not indicate high overall growth. The two springs with the highest potential growths were followed by two summers with the highest potential weight reductions for both brook trout sizes. However, there was no correlation overall between spring and summer growths for $50 \mathrm{~g}$ brook trout, and only a slight negative correlation for $10 \mathrm{~g}$ brook trout. The two years of highest spring growth and greatest summer reductions could have happened to $50 \mathrm{~g}$ brook trout because of their increased size at the beginning of summer. Even though there is no correlation between spring and summer growths, a large adult brook trout may not have been able to consume enough food to meet its increased metabolic demands. The slight correlation for $10 \mathrm{~g}$ brook trout could be related to food availability. The limited food selection means the food availability may not be as energetically profitable to a larger brook trout compared to a smaller brook trout, resulting in greater weight reductions during summer.

There is variation from year to year for $10 \mathrm{~g}$ and $50 \mathrm{~g}$ brook trout. Cooler water temperatures were correlated with higher annual growths for both sizes. Cooler water temperatures were also correlated with higher summer growths. However, water temperatures were minimally correlated with spring temperatures. A warmer or cooler spring did not impact growth. A possible explanation could be variation in spring water temperatures. The average temperature was used to determine if there was a correlation with net growth. Increased variation in water temperature around this mean could benefit or limit growth. For instance, years with higher variability could mean brook trout are exposed to temperatures near its optimal temperature $\left(18^{\circ} \mathrm{C}\right)$ more often than years with steadier temperatures. The increased exposure to brook trout's optimal temperature could outweigh the negative results of lower spring 
temperatures. Theoretically, this would result in an overall more productive spring for brook trout, even though they were exposed to lower than normal water temperatures. Fall growth was strongly correlated with water temperature in small and large tributaries and slightly correlated in cool and warm mainstems for $10 \mathrm{~g}$ brook trout. The limited food sources and availability in tributaries compared to mainstem sites could have likely caused this correlation. This results in temperature having a more direct impact on tributaries than mainstem sites. Fall growth and temperatures were not as negatively correlated in small tributaries as they were in other three site types for $50 \mathrm{~g}$ brook trout. Reproduction in small tributaries is likely the reason for there not being as strong of a correlation.

One of the highest growth potentials occurred in 2009 for $10 \mathrm{~g}$ brook trout and 2006 for $50 \mathrm{~g}$ brook trout. The lowest for both sizes happened in 2005. Average stream temperatures were lowest in 2006 and 2009 for all site types. Stream temperatures were some of the highest in 2005. There were critical periods in the summer and fall during these years that separated a high growth year from a low growth year for small and large adult trout. Water temperatures were cooler in the good growth year during each critical period. Cooler summer and fall temperatures positively affected brook trout growth.

Many studies have shown migration is high risk with high reward (Power 1980, Stolarski and Hartman 2010). Individuals migrate for the possibility of better fitness, despite greater risks of mortality (Power 1980). Resident individuals remain in the same location because it is low risk with little reward (Power 1980). There is typically a lower fitness potential, but lower mortality risks (Power 1980). Many foragers will take the additional risks associated with migrating, such as predators, for better feeding areas (Werner and Gilliam 1984). Stolarski and Hartman (2010) found that fluvial age-1 and age-2 brook trout were significantly longer than 
residential brook trout of the same age. Age-2 fluvial brook trout were also better fit than age-2 resident brook trout. There may be an initial decrease in fitness when migrating, but it will quickly be recouped once the individual is in a sufficient habitat (Hilderbrand and Kershner 2004).

Our results indicate it would be beneficial for a brook trout to migrate from tributaries to the mainstem. There is limited potential growth in small tributaries, which is where brook trout typically spawn (Petty et al. 2005). Migrating into a larger tributary would benefit brook trout between the sizes we studied. Once they became large enough, migrating into the mainstem would allow for the most potential growth.

To fully benefit from migrating, larger brook trout may need to delay reproduction. Brook trout in large and small tributaries displayed reductions in weight during fall, which is the spawning period for brook trout. If large brook trout were to remain in the mainstem and postpone reproduction, they would likely increase their size and fitness because of a higher growth potential during this time period. In turn, increased size and fitness may increase fecundity in subsequent years. Drawbacks to this approach are the increased possibility of stochastic events in the mainstem (Petty et al. 2003, Hakala and Hartman 2004) and the relatively short lifespan of trout (Stolarski and Hartman 2010). Small tributary streams are physically stable compared to high variability in mainstem sites. Extreme variability of discharge may pose a potentially harmful risk for delaying reproduction. Extreme droughts limit available habitat and food resources, which cause decreased fitness in brook trout (Hakala and Hartman 2004). Reduced streamflows have also been shown to limit the growth of rainbow trout (Harvey et al. 2006). Brook trout older than age-4 are rarely found throughout the Appalachians (Stolarksi and Hartman 2010). 
Competition is a factor not accounted for that could decrease growth potential. Intra- and interspecific competition are possibly influential to brook trout growth and behavior. Several studies have indicated brook trout populations can show density dependence (Petty et al. 2005, Utz and Hartman 2009, Grossman et al. 2012). Petty et al (2005) showed density dependence in the Second Fork watershed. Interspecific competition has been shown to decrease growth rates and overall fitness (Guénard et al. 2012). Brown trout (Salmo trutta) and rainbow trout are commonly found in the mainstem of upper Shavers Fork and are a source of interspecific competition. Brown trout have been documented to prey on small brook trout and could compete for habitat and food resources with larger brook trout (Krueger and May 1991). Rainbow trout have higher growth rates in their first year compared to brook trout, which gives them a competitive advantage. They will also outcompete brook trout for the best quality habitat (Krueger and May 1991).

Fish are fluvial on daily (Lucas et al. 2001) and seasonal scales (Lucas et al. 2001, Petty et al. 2005). Fish often migrate on a daily scale to find the best available microhabitats (Lucas et al. 2001). In fact, it is essential for fish to move to maximize survivorship, reproduction, and growth because of spatial and temporal variability (Petty and Grossman 2010). Seasonal migration is believed to occur as an adaptive strategy to increase fitness of a fish in habitats with seasonal variation by increasing its growth and survival (Northcote 1978). Our results suggest that individuals that migrate to mainstem sites have larger growth potentials. Stolarski and Hartman (2010) have shown that fluvial brook trout have longer lengths at age-1 and age-2 than sedentary trout and have better fitness at age- 2 .

Bioenergetics models are often used and evaluated as a method for determining fish growth based on temperature and consumption (Railsback and Rose 1999, Hartman and Kitchell 
2008, Chipps and Wahl 2008). There have been differences shown between modeled growth and actual growth because of inaccuracies using fish bioenergetics models (Chipps and Wahl 2008). Modeled consumption rates of many studies are higher than field observed consumption (Chipps and Wahl 2008). Since our consumption rates were modeled (Thorne 2004) using Fish Bioenergetics 3.0, our models could have overestimated growth.

Another source for error in our estimated growth could come when summer temperatures rise above the $21^{\circ} \mathrm{C}$ metabolic threshold of brook trout. Salmonids have been shown to select microhabitats that result in positive growth (Farley and Trudel 2009). Petty et al. (2012) showed that brook trout in the mainstem of Shavers were never found in microhabitats with a temperature exceeding $20^{\circ} \mathrm{C}$, even if ambient water temperatures were higher. Brook trout movement during the summer was significantly related to maximum water temperature. When the temperature was $12-18^{\circ} \mathrm{C}$, trout movement was minimal. Once maximum temperatures increased above $18^{\circ} \mathrm{C}$, trout frequently moved. Brook trout would search for cooler microhabitats. These microhabitats were usually associated with coldwater seeps, groundwater upwellings, and tributary confluences (Petty et al. 2012). This suggests that when water temperatures increased above $20^{\circ} \mathrm{C}$ in mainstem sites, our models were likely underestimating brook trout growth since they would have sought out more suitable microhabitats. However, this is not to say the pattern we observed is inaccurate. Sweka and Hartman (2001) showed trout growth is slowest in the summer throughout the Appalachians because of a decreased availability of prey. Even though salmonids typically choose microhabitats that promote growth, they do not always do so. Another study showed rainbow trout did not always choose best microhabitats from an energy standpoint (Braaten et al. 1997). Some rainbow trout were found in stream currents that were too fast and caused a reduction in weight, since they were expending more 
energy to stay in the current than they were consuming (Braaten et al. 1997). Brook trout could possibly behave in a similar manner at times when it comes to microhabitat selection.

There can be drastic variances in depth, current velocity, and food availability within small areas of a stream (Petty and Grossman 2010). However, Tyler and Brandt (2001) states spatially modeling growth rates with bioenergetics modeling are acceptable, despite habitat heterogeneity. Therefore, there is no concern for errors due to habitat heterogeneity.

Management within the upper Shavers Fork watershed is essential for conserving native brook trout populations. Stream restoration could be valuable to brook trout populations. Creating pools and adding large woody debris into the stream would add new habitat. Narrowing and deepening the stream at locations that are wide and shallow could decrease water temperatures by reducing the affect of air temperature. Specific sites that are wide and shallow include Shavers 43.0 and 43.8. Recently, there have been stream restoration efforts within the mainstem of Shavers Fork to address some of these issues.

Another issue that should be addressed is the water temperature at Shavers 7.5, which is located directly below a dam. Water temperatures at this site are some of the highest in the watershed, yet they should be the lowest. The dam is supposed to be bottom released, but it appears it is likely top released. The increased initial water temperatures in the mainstem probably have a cascading effect throughout the upper portion of the watershed by causing increased water temperatures down stream.

There is spatial and temporal variability in brook trout growth potential in the upper Shavers Fork watershed. Specific sites and seasons yield higher growth potential than other sites or seasons. Cool and warm mainstem sites in the spring are best for both small and large adult brook trout. A $10 \mathrm{~g}$ brook trout is has better growth potential in tributaries during the summer, 
while a $50 \mathrm{~g}$ brook trout has better growth potential in the mainstem. Shavers 12.9 is one of the better mainstem sites for $10 \mathrm{~g}$ and $50 \mathrm{~g}$ brook. Migrating to better sites could provide benefits to brook trout fitness. However, there are risks with migrating to higher quality sites. Tributaries offer some potential growth for small adult brook trout, but cause significant growth reductions in large adult brook trout. Mainstem locations offer limited growth to small adults, but have high growth potentials for large adults. This study reemphasizes the effect site type and season has on brook trout growth potential and stresses the magnitude these variables have on growth. 


\section{Literature Cited}

Bartell, S.M., J.E. Breck, R.H. Gardner, and A.L. Brenkert. 1986. Individual parameter perturbation and error analysis of fish bioenergetics models. Canadian Journal of Fisheries and Aquatic Sciences 43: 160-168.

Beer, W.N., and J.J. Anderson. 2011. Sensitivity of juvenile salmonid growth to future climate trends. River Research and Applications 27: 663-669.

Bevelhimer, M.S., and S.M. Adams. 1993. A bioenergetics analysis of diel vertical migration by Kokanee salmon, Oncorhynchus nerka. Canadian Journal of Fisheries and Aquatic Sciences 50: 2336-2349.

Braaten, P.J., P.D. Dey, and T.C. Annear. 1997. Development and evaluation of bioenergeticbased habitat suitability criteria for trout. Regulated Rivers: Research \& Management 13: $345-356$.

Brandt, S.B. 1993. The effect of thermal fronts on fish growth: a bioenergetics evaluation of food and temperature. Estuaries 16: 142-159.

Brönmark, C., J. Brodersen, B.B. Chapman, A. Nicolle, P.A. Nilsson, C. Skov. and L.A. Hansson. 2010. Regime shifts in shallow lakes: the importance of seasonal fish migration. Hydrobiologia 646: 91-100.

Budy, P., M. Baker, and S.K. Dahle. 2011. Predicting fish growth potential and identifying water quality constraints: a spatially-explicit bioenergetics approach. Environmental Management 48: 691-709.

Busch, S., B.M. Johnson, and T. Mehner. 2011. Energetic costs and benefits of cyclic habitat switching: a bioenergetics model analysis of diel vertical migration in coregonids. Canadian Journal of Fisheries and Aquatic Sciences 68: 706-717. 
Chipps, S.R. and D.H. Wahl. 2008. Bioenergetics modeling in the 21 st century: reviewing new insights and revisiting old constraints. Transactions of the American Fisheries Society 137: 298-313.

Cummins, K.W. and J.C. Wuycheck. 1971. Caloric equivalents for investigations in ecological energetics. International Association of Theoretical and Applied Limnology 18: 1-158.

Farley, E.V., Jr. and M. Trudel. 2009. Growth rate potential of juvenile sockeye salmon in warmer and cooler years on the eastern Bering sea shelf. Journal of Marine Biology 2009: $1-10$.

Grossman, G.D., A. Nuhfer, T. Zorn, G. Sundin, and G. Alexander. 2012. Population regulation brook trout (Salvelinus fontinalis) in Hunt Creek, Michigan: a 50-year study. Freshwater Biology 57: 1434-1448.

Guénard, G., D. Boisclair, O. Ugedal, T. Forseth, B. Jonsson, and I.A. Fleming. 2012. An experimental study of the multiple effects of brown trout Salmo trutta on the bioenergetics of two arctic charr Salvelinus alpinus morphs. Journal of Fish Biology 81: 1248-1270.

Hakala, J.P. and K.J. Hartman. 2004. Drought effect on stream morphology and brook trout (Salvelinus fontinalis) populations in forested headwater streams. Hydrobiologia 515: 203-213.

Hanson, P.C., T.B. Johnson, D.E. Schindler, and J.F. Kitchell. 1997. Fish Bioenergetics 3.0. University of Wisconsin Sea Grant Institute.

Hartman, K.J. and M.K. Cox. 2008. Refinement and testing of a brook trout bioenergetics model. Transactions of the American Fisheries Society 137: 357-363.

Hartman, K.J. and J.F. Kitchell. 2008. Bioenergetics modeling: progress since the 1992 
symposium. Transactions of the American Fisheries Society 137: 216-223.

Hartman, K.J. and J.A. Sweka. 2001. Development of a bioenergetics model for Appalachian brook trout. Proceedings of the Southeastern Association of Fish and Wildlife Agencies 55: $38-51$.

Harvey, B.C., R.J. Nakamoto, and J.L. White. 2006. Reduced streamflow lowers dry-season growth of rainbow trout in a small stream. Transactions of the American Fisheries Society 135: 998-1005.

Hilderbrand, R.H. and J.L. Kershner. 2004. Are there differences in growth and condition between mobile and resident cutthroat trout? Transactions of the American Fisheries Society 133: 1042-1046.

Jonsson, N., T.F. Næsje, B. Jonsson, R. Saksgård, and O.T. Sandlund. 1999. The influence of piscivory on life history traits of brown trout. Journal of Fish Biology 55: 1129-1141.

Kitchell, J.F., J.F. Koonce, R.V. O’Neill, H.H. Shugart, J.J. Magnuson, and R.S. Booth. 1974. Model of fish biomass dynamics. Transactions of the American Fisheries Society 103: 786-798.

Kitchell, J.F., D.J. Stewart, and D. Weininger. 1977. Applications of a bioenergetics model to yellow perch (Perca flavescens) and walleye (Stizostedion vitreum vitreum). Journal of the Fisheries Research Board of Canada 34: 1910-1921.

Krueger, C.C., and B. May. 1991. Ecological and genetic effects of salmonid introductions in North America. Canadian Journal of Fisheries and Aquatic Sciences 48: 66-77.

Leach, J.A., R.D. Moore, S.G. Hinch, and T. Gomi. 2012. Estimation of forest harvestinginduced stream temperature changes and bioenergetics consequences for cutthroat trout 
in a coastal stream in British Columbia, Canada. Aquatic Sciences 74: 427-441.

Lucas, M.C., E. Baras, T.J. Thom, A. Duncan, and O. Slavik. 2001. Migration of Freshwater Fishes. Blackwell Science, Oxford.

Madenjian, C.P., D.V. O’Connor, S.M. Chernyak, R.R. Rediske, and J.P. O’Keefe. 2004. Evaluation of a chinook salmon (Oncorhynchus tshawytscha) bioenergetics model. Canadian Journal of Fisheries and Aquatic Sciences 61: 627-635.

Marschall, E. A. and L. B. Crowder. 1996. Assessing population responses to multiple anthropogenic effects: a case study with brook trout. Ecological Applications 6: 152-167.

Northcote, T.G. 1978. Migratory strategies and production of freshwater fishes. Ecology of Freshwater Fish Production 326-359.

Petty, J.T. and G.D. Grossman. 2010. Giving-up densities and ideal pre-emptive patch use in a predatory benthic stream fish. Freshwater Biology 55: 780-793.

Petty, J.T., J. Freund, P.J. Lamothe, and P.M. Mazik. 2003. Quantifying the microhabitat characteristics of hydraulic channel units in the upper Shavers Fork basin. Proceedings of the Annual Conference Southeastern Association of Fish and Wildlife Agencies 55: $81-94$.

Petty, J.T., P.J. Lamothe, and P.M. Mazik. 2005. Spatial and seasonal dynamics of brook trout populations inhabiting a central Appalachian watershed. Transactions of the American Fisheries Society 134: 572-587.

Petty, J.T., J.L. Hansbarger, B.M. Huntsman, and P.M. Mazik. 2012. Brook trout movement in response to temperature, flow, and thermal refugia within a complex Appalachian riverscape. Transactions of the American Fisheries Society 141: 1060-1073. 
Power, G. 1980. The brook charr, Salvelinus fontinalis. In: E.K. Balon (eds) Charrs: Salmonid Fishes of the Genus Salvelinus. Dr. W. Junk Publishers 141-201.

Railsback, S.F. and K.A. Rose. 1999. Bioenergetics modeling of stream trout growth: temperature and food consumption effects. Transactions of the American Fisheries Society 128: 241-256.

Robinson, J.M., D.C. Josephson, B.C. Weidel, and C.E. Kraft. 2010. Influence of variable interannual summer water temperatures on brook trout growth, consumption, reproduction, and mortality in an unstratified Adirondack lake. Transactions of the American Fisheries Society 139: 685-699.

Stolarski, J.T. and K.J. Hartman. 2010. Comparisons of growth and condition of fluvial and resident brook trout within partially migratory populations. Fisheries Management and Ecology 17: 33-39.

Sweka, J.A. and K.J. Hartman. 2001. Effects of turbidity on prey consumption and growth in brook trout and implications for bioenergetics modeling. Canadian Journal of Fisheries and Aquatic Sciences 58: 386-393.

Thorne, D.W. 2004. Spatial and seasonal variation in brook trout diet, growth, and consumption in a complex Appalachian watershed. Master's Thesis, West Virginia University.

Tyler, J.A. and S.B. Brandt. 2001. Do spatial models of growth rate potential reflect fish growth in a heterogeneous environment? A comparison of model results. Ecology of Freshwater Fish 10: 43-56.

Utz, R.M. and K.J. Hartman. Density-dependent individual growth and size dynamics of central Appalachian brook trout (Salvelinus fontinalis). Canadian Journal of Fisheries 
and Aquatic Sciences 66: 1072-1080.

Werner, E.E. and J.F. Gilliam. 1984. The ontogenetic niche and species interactions in sizestructured populations. Annual Review of Ecology and Systematics 1: 393-425.

Wigington, P.J., J.P. Baker, D.R. DeWalle, W.A. Kretser, P.S. Murdoch, H.A. Simonin, J. Van Sickle, M.K. McDowell, D.V. Peck, W.R. Barchet. 1996. Episodic acidification of small streams in the northeastern United States: episodic response project. Ecological Applications 6: 374-388.

Winberg, G.G. 1956. Rate of metabolism and food requirements of fishes. Fisheries Research Board of Canada Translation Series 194. 
Table 1. Site type, drainage area, and coordinates of all sites $(n=18)$ studied. $S T=$ small tributary $(n=2), L T=$ large tributary $(n=2), M S=$ mainstem $(n=14)$.

\begin{tabular}{lccc}
\hline Site & Drainage Area $\left(\mathrm{km}^{2}\right)$ & Latitude & Longitude \\
\hline Second 2.1 & 2.1 & 38.47734 & -79.9163 \\
Second 3.4 & 3.4 & 38.46966 & -79.93203 \\
Second 10.4 & 10.4 & 38.4851 & -79.92834 \\
Second 15.4 & 15.4 & 38.50246 & -79.9325 \\
Shavers 7.5 & 7.5 & 38.42228 & -79.97949 \\
Shavers 12.9 & 12.9 & 38.43995 & -79.96226 \\
Shavers 20.7 & 20.7 & 38.45435 & -79.95747 \\
Shavers 27.9 & 27.9 & 38.47315 & -79.96084 \\
Shavers 29.5 & 29.5 & 38.47697 & -79.95904 \\
Shavers 31.7 & 31.7 & 38.48502 & -79.95846 \\
Shavers 38.7 & 38.7 & 38.48651 & -79.95763 \\
Shavers 41.1 & 41.1 & 38.49557 & -79.95054 \\
Shavers 43.0 & 43.0 & 38.50275 & -79.94261 \\
Shavers 43.8 & 43.8 & 38.50283 & -79.93402 \\
Shavers 59.4 & 59.4 & 38.50625 & -79.93372 \\
Shavers 65.1 & 65.1 & 38.52445 & -79.93544 \\
Shavers 89.1 & 89.1 & 38.56643 & -79.89939 \\
Shavers 117.4 & 117.4 & 38.57431 & -79.90212 \\
\hline
\end{tabular}


Table 2. Mean daily stream temperature $\left({ }^{\circ} \mathrm{C}\right)$ each year analyzed across four site types. ST $=$ small tributary. $\mathrm{LT}=$ large tributary. $\mathrm{CMS}=$ cool mainstem. WMS $=$ warm mainstem.

\begin{tabular}{ccccc}
\hline Year & ST & LT & CMS & WMS \\
\hline 2001 & 10.2 & 10.9 & 13.1 & 13.8 \\
2002 & 10.7 & 11.4 & 13.6 & 14.4 \\
2003 & 10.3 & 10.8 & 12.8 & 13.3 \\
2004 & 10.8 & 11.5 & 13.7 & 14.4 \\
2005 & 11.0 & 12.2 & 14.4 & 15.8 \\
2006 & 10.0 & 10.7 & 12.8 & 13.7 \\
2007 & 10.5 & 11.2 & 13.6 & 14.7 \\
2009 & 10.2 & 10.9 & 13.1 & 13.9 \\
2010 & 10.9 & 11.8 & 14.2 & 15.3 \\
2012 & 10.7 & 11.7 & 14.1 & 15.3 \\
\hline
\end{tabular}


Table 3. Annual net growth $(\mathrm{g})$ in each site for a $10 \mathrm{~g}$ brook trout.

\begin{tabular}{|c|c|c|c|c|c|c|c|c|c|c|}
\hline Site & 2001 & 2002 & 2003 & 2004 & 2005 & 2006 & 2007 & 2009 & 2010 & 2012 \\
\hline Second 2.1 & 7.1 & 4.5 & 6.3 & 5.1 & 3.9 & 8.5 & 5.9 & 8.1 & 5.6 & 6.6 \\
\hline Second 3.4 & 7.7 & 4.7 & 7.1 & 5.6 & 1.2 & 7.6 & 4.4 & 6.8 & 4.2 & 4.8 \\
\hline Second 10.4 & 7.2 & 4.5 & 6.9 & 5.2 & -0.2 & 8.1 & 5.9 & 8.2 & 5.1 & 5.1 \\
\hline Second 15.4 & 5.2 & 1.8 & 4.3 & 3.3 & -1.2 & 4.8 & 1.2 & 4.2 & 1.0 & 1.9 \\
\hline Shavers 7.5 & -2.6 & -4.5 & -2.7 & -3.7 & -4.7 & -0.6 & -2.8 & 0.1 & -0.9 & -0.1 \\
\hline Shavers 12.9 & 8.3 & 3.5 & 6.3 & 5.4 & -0.5 & 7.0 & 3.8 & 7.0 & 3.8 & 5.1 \\
\hline Shavers 20.7 & 2.8 & -0.2 & 2.4 & 1.6 & -2.1 & 4.0 & 1.0 & 4.6 & 1.9 & 3.5 \\
\hline Shavers 27.9 & 3.2 & -0.4 & 2.9 & 2.1 & -3.5 & 3.1 & -0.4 & 3.4 & -0.1 & 1.1 \\
\hline Shavers 29.5 & 3.5 & 0.2 & 3.2 & 2.8 & -3.0 & 3.4 & -0.1 & 3.4 & 0.0 & 1.3 \\
\hline Shavers 31.7 & 2.1 & -0.7 & 2.1 & 1.6 & -2.9 & 2.7 & -0.3 & 3.1 & 0.6 & 2.2 \\
\hline Shavers 38.7 & 4.7 & 0.9 & 2.6 & 2.4 & -1.3 & 3.7 & -0.4 & 3.2 & -0.1 & 2.0 \\
\hline Shavers 41.1 & 3.6 & -0.2 & 3.0 & 2.6 & -3.7 & 2.3 & -1.2 & 2.3 & -0.8 & 0.6 \\
\hline Shavers 43.0 & 8.6 & 3.1 & 7.9 & 7.3 & -5.4 & 1.9 & -1.9 & 1.1 & -1.3 & -0.1 \\
\hline Shavers 43.8 & 1.1 & -2.2 & 1.0 & 0.4 & -5.6 & -0.1 & -3.2 & 0.0 & -2.6 & -1.0 \\
\hline Shavers 59.4 & 1.9 & -0.9 & 2.0 & 1.1 & -4.9 & 3.7 & 1.8 & 4.7 & 0.8 & 1.0 \\
\hline Shavers 65.1 & 0.6 & -1.9 & 0.9 & 0.5 & -4.1 & 0.7 & -2.4 & 0.7 & -1.3 & 0.3 \\
\hline Shavers 89.1 & 0.9 & -2.1 & 1.4 & 0.9 & -5.2 & -0.2 & -2.8 & 0.1 & -2.3 & -0.9 \\
\hline Shavers 117.4 & -0.2 & -2.3 & 0.5 & -0.2 & -3.9 & 0.8 & -1.7 & 1.5 & -1.0 & 0.2 \\
\hline
\end{tabular}


Table 4. Mean annual net growth (g) for a $10 \mathrm{~g}$ brook trout across four site types. $\mathrm{ST}=$ small tributary. $\mathrm{LT}=$ large tributary. $\mathrm{CMS}=$ cool mainstem. $\mathrm{WMS}=$ warm mainstem.

\begin{tabular}{ccccc}
\hline Site & ST & LT & CMS & WMS \\
\hline 2001 & 7.4 & 6.2 & 3.3 & 1.0 \\
2002 & 4.6 & 3.1 & -0.1 & -2.1 \\
2003 & 6.7 & 5.6 & 3.1 & 1.2 \\
2004 & 5.4 & 4.3 & 2.4 & 0.7 \\
2005 & 2.5 & -0.7 & -3.3 & -5.4 \\
2006 & 8.0 & 6.4 & 3.2 & -0.2 \\
2007 & 5.1 & 3.6 & -0.2 & -3.0 \\
2009 & 7.4 & 6.2 & 3.4 & 0.0 \\
2010 & 4.9 & 3.0 & 0.0 & -2.4 \\
2012 & 5.7 & 3.5 & 1.2 & -1.0 \\
\hline
\end{tabular}


Table 5. Two way ANOVA results for $10 \mathrm{~g}$ brook trout net growth against site and season.

\begin{tabular}{lcccccl}
\hline & Df & Sum Sq & Mean Sq & $\mathrm{F}$ & $\operatorname{Pr}(>\mathrm{F})$ & \\
\hline site & 3 & 93.15 & 31.05 & 9.1929 & $1.81 \mathrm{E}-05$ & $* * *$ \\
season & 2 & 2124.53 & 1062.26 & 314.5038 & $2.20 \mathrm{E}-16$ & $* * *$ \\
site:season & 6 & 508.62 & 84.77 & 25.0976 & $2.20 \mathrm{E}-16$ & $* * *$ \\
Residuals & 108 & 364.78 & 3.38 & & & \\
\hline
\end{tabular}

Table 6. Tukey's test results for $10 \mathrm{~g}$ brook trout final net growth between sites. ST = small tributary. $\mathrm{LT}=$ large tributary. $\mathrm{CMS}=$ cool mainstem. $\mathrm{WMS}=$ warm mainstem.

\begin{tabular}{lcccc}
\hline Site & Difference & Lower & Upper & p adj \\
\hline CMS-WMS & 0.8 & -0.4 & 2.0 & 0.3 \\
LT-WMS & 1.7 & 0.5 & 3.0 & 0.0 \\
ST-WMS & 2.3 & 1.1 & 3.5 & 0.0 \\
LT-CMS & 0.9 & -0.3 & 2.2 & 0.2 \\
ST-CMS & 1.5 & 0.3 & 2.7 & 0.0 \\
ST-LT & 0.6 & -0.7 & 1.8 & 0.6 \\
\hline
\end{tabular}

Table 7. Tukey's test results for $10 \mathrm{~g}$ brook trout potential net growth between seasons.

\begin{tabular}{lcccc}
\hline Season & Difference & Lower & Upper & p adj \\
\hline fall-summer & 3.1 & 2.1 & 4.0 & 0.0 \\
spring-summer & 10.1 & 9.1 & 11.0 & 0.0 \\
spring-fall & 7.0 & 6.0 & 8.0 & 0.0 \\
\hline
\end{tabular}


Table 8. Annual net growth $(\mathrm{g})$ in each site for a $50 \mathrm{~g}$ brook trout.

\begin{tabular}{|c|c|c|c|c|c|c|c|c|c|c|}
\hline Site & 2001 & 2002 & 2003 & 2004 & 2005 & 2006 & 2007 & 2009 & 2010 & 2012 \\
\hline Second 2.1 & -30.2 & -34.3 & -31.3 & -33.7 & -35.1 & -28.0 & -31.7 & -28.9 & -33.1 & -31.6 \\
\hline Second 3.4 & -29.1 & -33.9 & -29.9 & -32.9 & -38.9 & -29.2 & -33.9 & -30.8 & -35.3 & -34.3 \\
\hline Second 10.4 & -7.7 & -14.8 & -8.3 & -13.6 & -26.5 & -5.6 & -10.5 & -5.8 & -14.0 & -14.1 \\
\hline Second 15.4 & -13.1 & -21.6 & -14.9 & -18.8 & -28.8 & -13.8 & -22.5 & -16.1 & -24.5 & -22.5 \\
\hline Shavers 7.5 & 21.3 & 9.6 & 21.6 & 11.9 & 8.6 & 34.5 & 21.7 & 36.5 & 29.5 & 34.7 \\
\hline Shavers 12.9 & 80.1 & 55.9 & 71.3 & 63.0 & 35.0 & 75.3 & 58.2 & 72.9 & 55.9 & 62.3 \\
\hline Shavers 20.7 & 52.4 & 35.0 & 51.2 & 42.1 & 25.0 & 59.8 & 42.8 & 60.3 & 45.1 & 53.4 \\
\hline Shavers 27.9 & 53.0 & 34.0 & 53.6 & 44.0 & 16.3 & 54.4 & 34.5 & 53.5 & 33.9 & 39.7 \\
\hline Shavers 29.5 & 55.0 & 36.6 & 55.1 & 47.4 & 19.1 & 55.9 & 35.2 & 53.3 & 34.5 & 40.4 \\
\hline Shavers 31.7 & 48.2 & 31.7 & 49.3 & 41.0 & 19.8 & 53.1 & 34.5 & 52.0 & 37.7 & 45.9 \\
\hline Shavers 38.7 & 61.6 & 41.2 & 51.9 & 46.8 & 30.2 & 57.8 & 34.7 & 52.3 & 34.1 & 45.0 \\
\hline Shavers 41.1 & 55.3 & 34.4 & 54.1 & 46.2 & 15.3 & 50.5 & 28.7 & 47.4 & 29.5 & 36.5 \\
\hline Shavers 43.0 & 81.0 & 52.6 & 79.3 & 69.9 & 4.3 & 49.7 & 24.9 & 40.7 & 26.5 & 32.5 \\
\hline Shavers 43.8 & 41.5 & 22.8 & 43.2 & 33.8 & 2.3 & 36.9 & 16.0 & 34.3 & 19.1 & 27.1 \\
\hline Shavers 59.4 & 46.6 & 30.5 & 48.7 & 38.3 & 6.5 & 56.9 & 46.2 & 60.6 & 38.6 & 39.3 \\
\hline Shavers 65.1 & 39.6 & 24.1 & 42.4 & 33.9 & 12.2 & 41.5 & 21.4 & 38.8 & 26.7 & 31.2 \\
\hline Shavers 89.1 & 40.1 & 23.1 & 44.8 & 35.6 & 4.4 & 36.1 & 18.5 & 34.3 & 20.4 & 27.0 \\
\hline Shavers 117.4 & 34.7 & 21.7 & 39.9 & 29.9 & 12.6 & 41.7 & 25.9 & 42.7 & 28.1 & 34.0 \\
\hline
\end{tabular}


Table 9. Mean annual net growth (g) for a $50 \mathrm{~g}$ brook trout across four site types. $\mathrm{ST}=$ small tributary. $\mathrm{LT}=$ large tributary. $\mathrm{CMS}=$ cool mainstem. $\mathrm{WMS}=$ warm mainstem.

\begin{tabular}{ccccc}
\hline Site & ST & LT & CMS & WMS \\
\hline 2001 & -29.6 & -10.4 & 54.0 & 40.8 \\
2002 & -34.1 & -18.2 & 35.3 & 22.9 \\
2003 & -30.6 & -11.6 & 54.3 & 44.0 \\
2004 & -33.3 & -16.2 & 45.7 & 34.7 \\
2005 & -37.0 & -27.6 & 17.7 & 3.3 \\
2006 & -28.6 & -9.7 & 55.1 & 36.5 \\
2007 & -32.8 & -16.5 & 34.8 & 17.3 \\
2009 & -29.8 & -11.0 & 53.4 & 34.3 \\
2010 & -34.2 & -19.2 & 34.2 & 19.8 \\
2012 & -32.9 & -18.3 & 40.0 & 27.0 \\
\hline
\end{tabular}


Table 10. Two way ANOVA results for $50 \mathrm{~g}$ brook trout net growth against site and season.

\begin{tabular}{|c|c|c|c|c|c|c|}
\hline & Df & Sum Sq & Mean Sq & $F$ & $\operatorname{Pr}(>\mathrm{F})$ & \\
\hline site & 3 & 12537.4 & 4179.1 & 96.02 & $2.20 \mathrm{E}-16$ & $* * *$ \\
\hline season & 2 & 20496.6 & 10248.3 & 235.47 & $2.20 \mathrm{E}-16$ & $* * *$ \\
\hline site:season & 6 & 3661.2 & 610.2 & 14.02 & $9.60 \mathrm{E}-12$ & $* * *$ \\
\hline Residuals & 108 & 4700.5 & 43.5 & & & \\
\hline
\end{tabular}

Table 11. Tukey's test results for $50 \mathrm{~g}$ brook trout final net growth between sites. ST $=$ small tributary. $\mathrm{LT}=$ large tributary. $\mathrm{CMS}=$ cool mainstem. $\mathrm{WMS}=$ warm mainstem.

\begin{tabular}{lcccc}
\hline Site & Difference & Lower & Upper & p adj \\
\hline LT-ST & 5.5 & 1.0 & 9.9 & 0.0 \\
WMS-ST & 20.1 & 15.7 & 24.6 & 0.0 \\
CMS-ST & 24.9 & 20.5 & 29.4 & 0.0 \\
WMS-LT & 14.6 & 10.2 & 19.1 & 0.0 \\
CMS-LT & 19.4 & 15.0 & 23.9 & 0.0 \\
CMS-WMS & 4.8 & 0.4 & 9.2 & 0.0 \\
\hline
\end{tabular}

Table 12. Tukey's test results for 50g brook trout potential net growth between seasons.

\begin{tabular}{lcccc}
\hline Season & Difference & Lower & Upper & p adj \\
\hline fall-summer & 10.2 & 6.7 & 13.7 & 0.0 \\
spring-summer & 31.4 & 27.9 & 34.9 & 0.0 \\
spring-fall & 21.2 & 17.7 & 24.7 & 0.0 \\
\hline
\end{tabular}




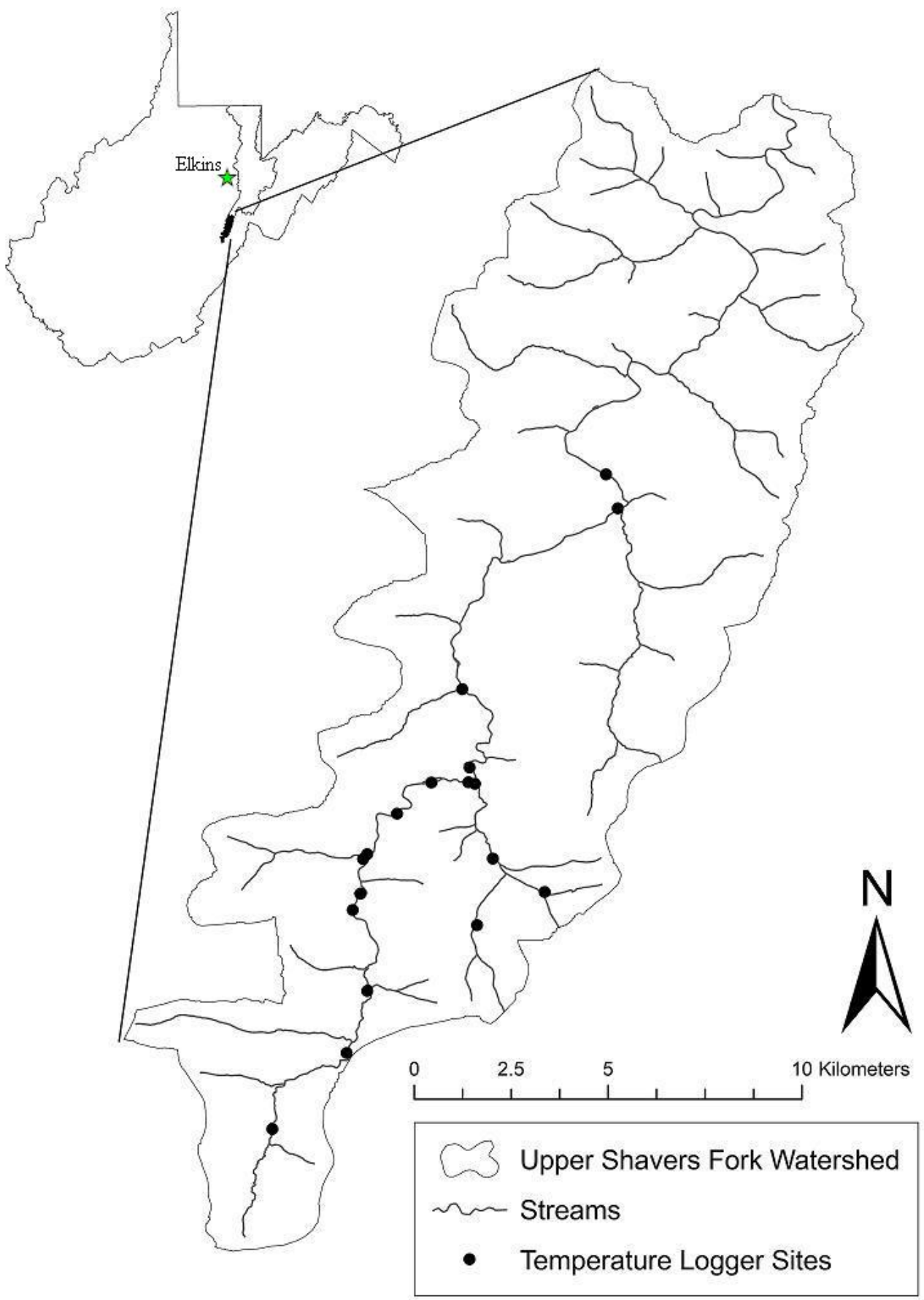

Figure 1. Location of all studied growth potential sites and corresponding temperature loggers used in modeling mean water temperature. 


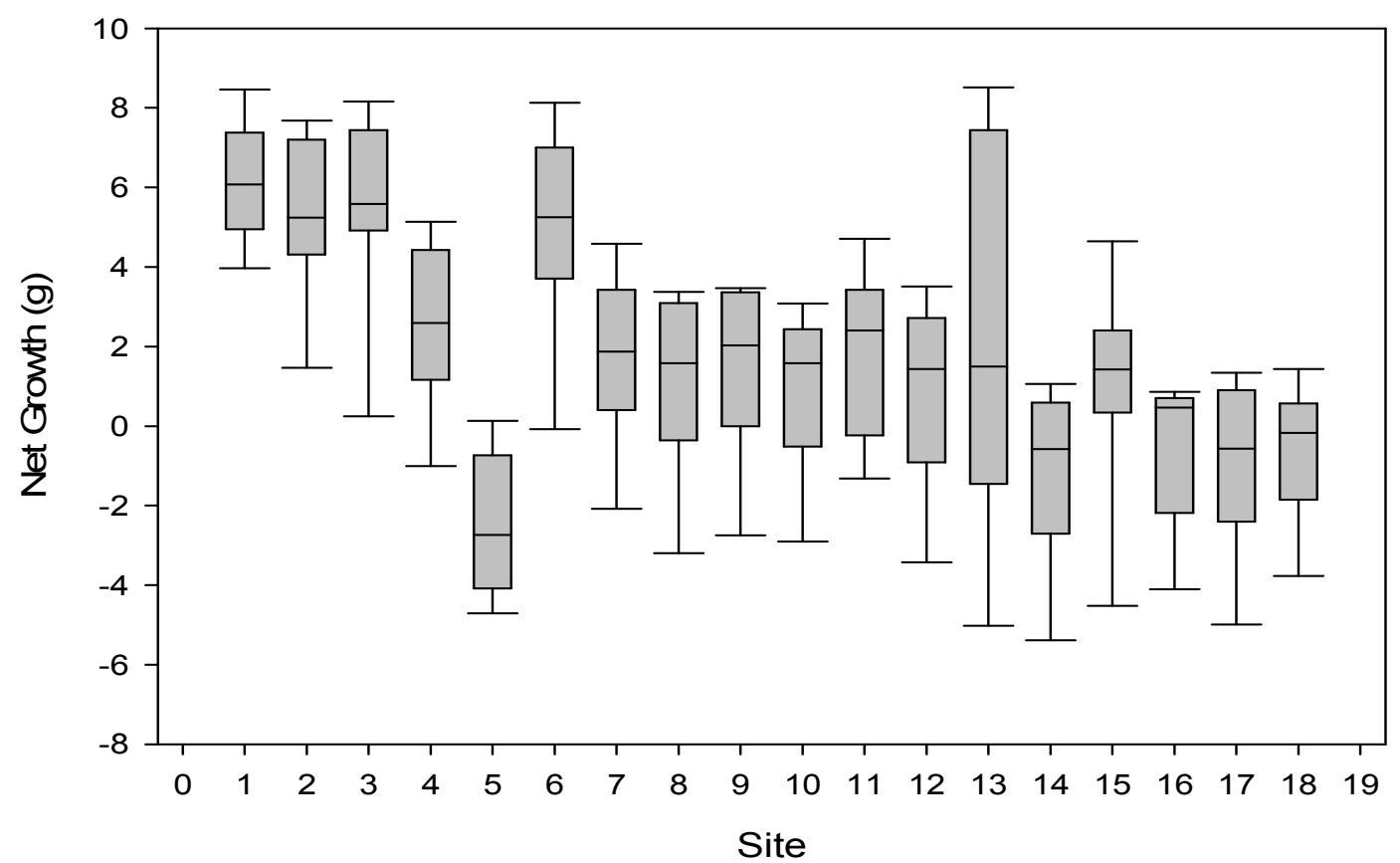

Figure 2. Net growth for 10g brook trout at each site location from 2001-2012.

\begin{tabular}{lc}
\hline Site & Graph Site \\
\hline Second 2.1 & 1 \\
Second 3.4 & 2 \\
Second 10.4 & 3 \\
Second 15.4 & 4 \\
Shavers 7.5 & 5 \\
Shavers 12.9 & 6 \\
Shavers 20.7 & 7 \\
Shavers 27.9 & 8 \\
Shavers 29.5 & 9 \\
Shavers 31.7 & 10 \\
Shavers 38.7 & 11 \\
Shavers 41.1 & 12 \\
Shavers 43.0 & 13 \\
Shavers 43.8 & 14 \\
Shavers 59.4 & 15 \\
Shavers 65.1 & 16 \\
Shavers 89.1 & 17 \\
Shavers 117.4 & 18 \\
\hline
\end{tabular}




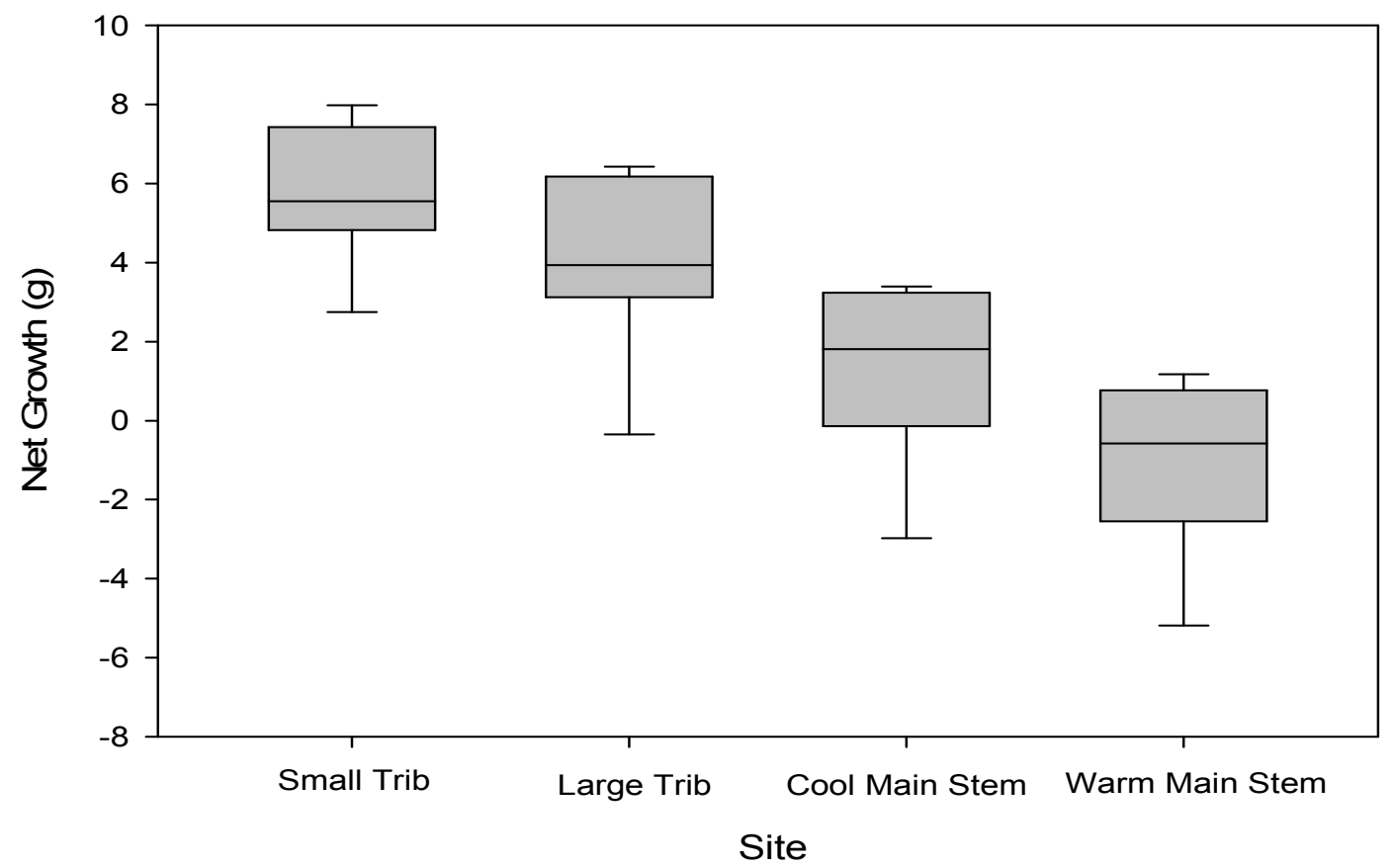

Figure 3. Average yearly net growth $(\mathrm{g})$ for a $10 \mathrm{~g}$ brook trout for each site type from 2001-2012. 


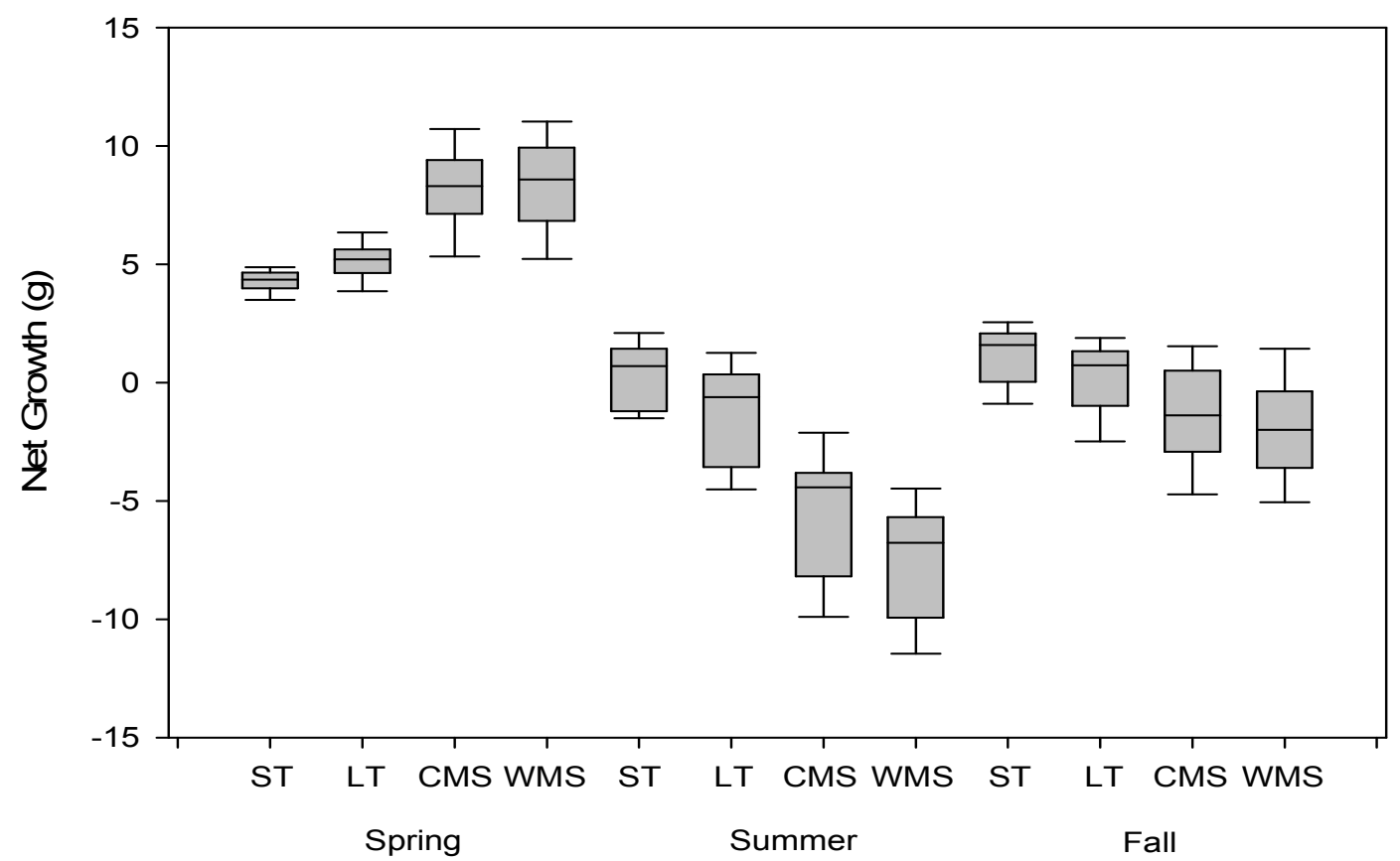

Figure 4. Seasonal and site type net potential growth (g) from 2001-2012 for a 10g brook trout. 


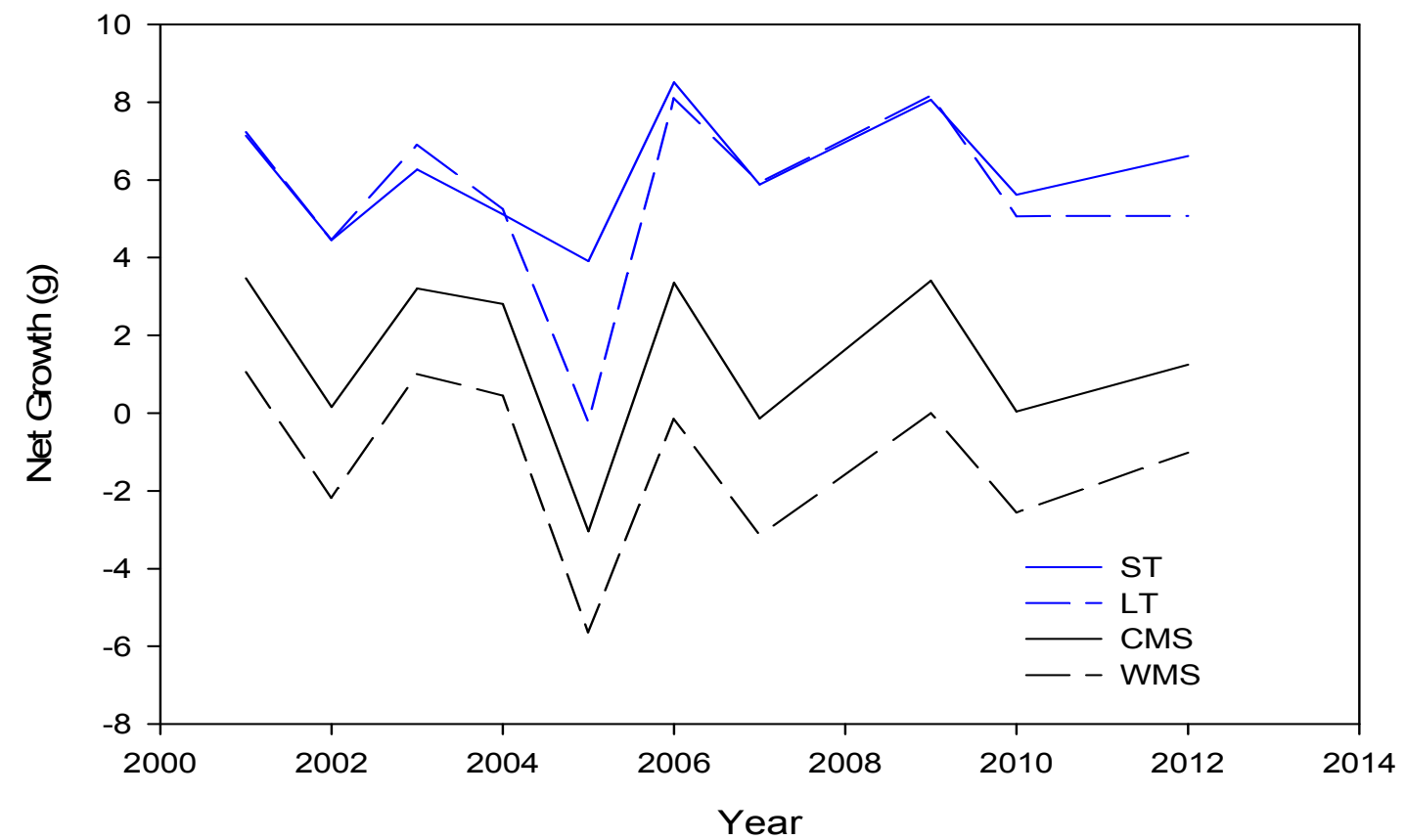

Figure 5. Annual net growth (g) for a $10 \mathrm{~g}$ brook trout in each site type. 


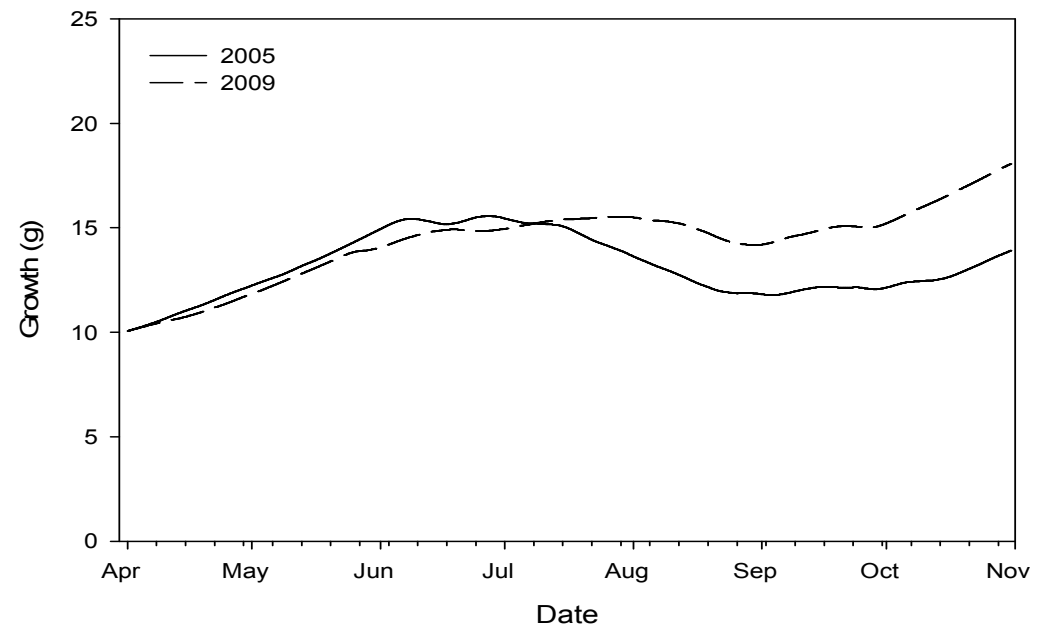

(a)

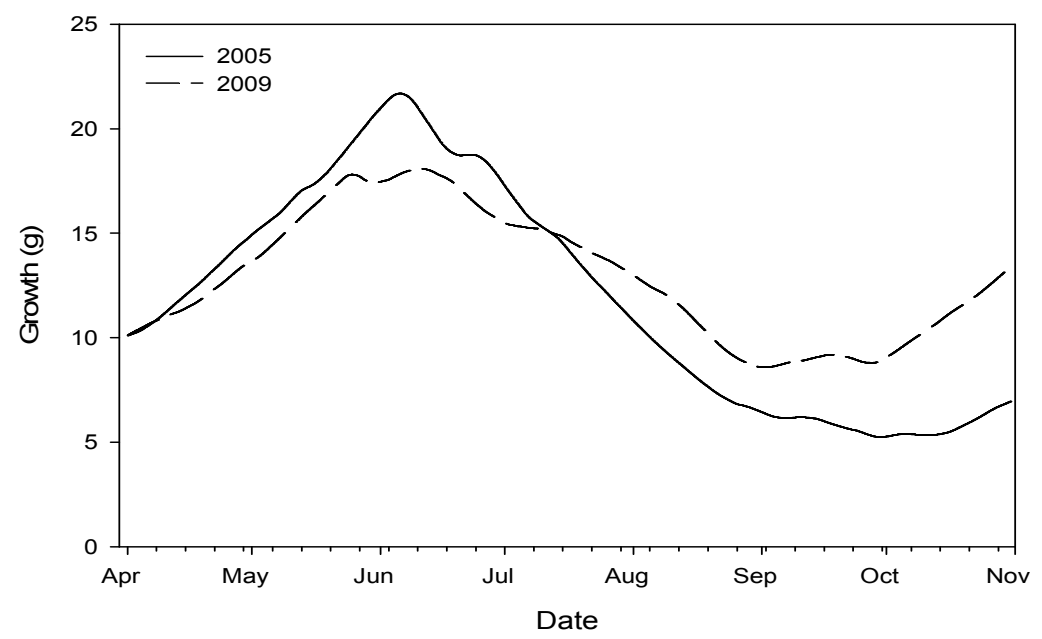

(c)

Figure 6. Good year (2009) and bad year (2005) of growth for a 10g brook trout in a (a) small tributary (b) large tributary (c) cool

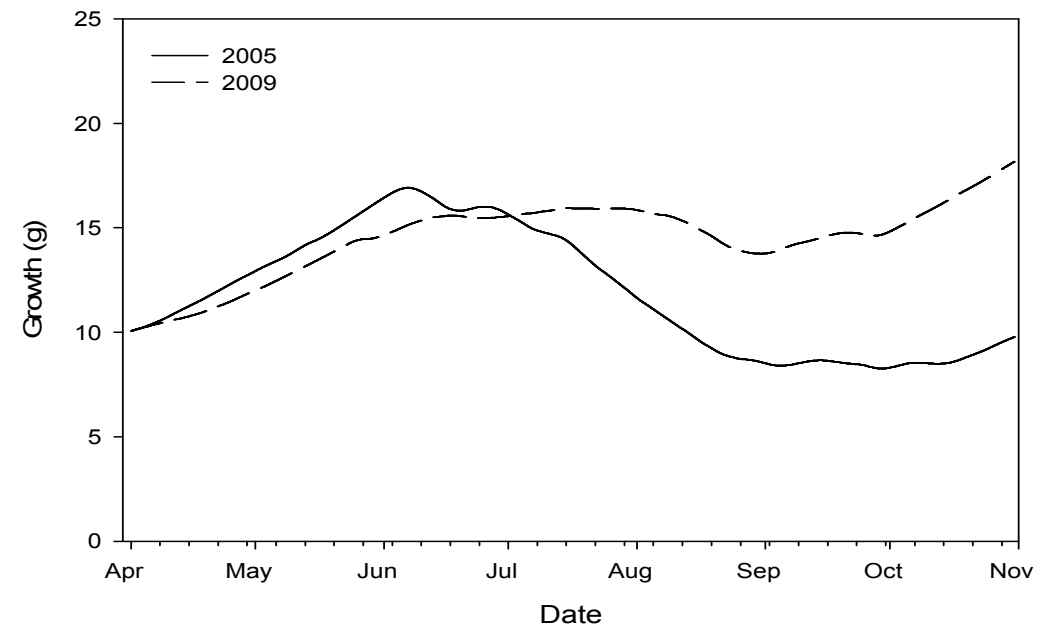

(b)

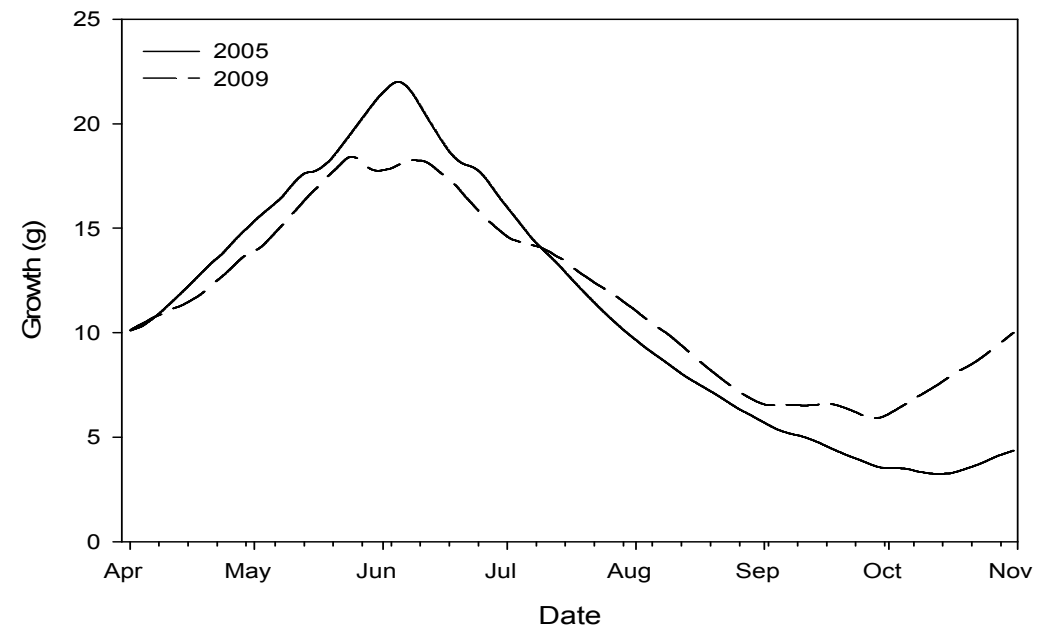

(d)

\section{mainstem and (d) warm mainstem.}




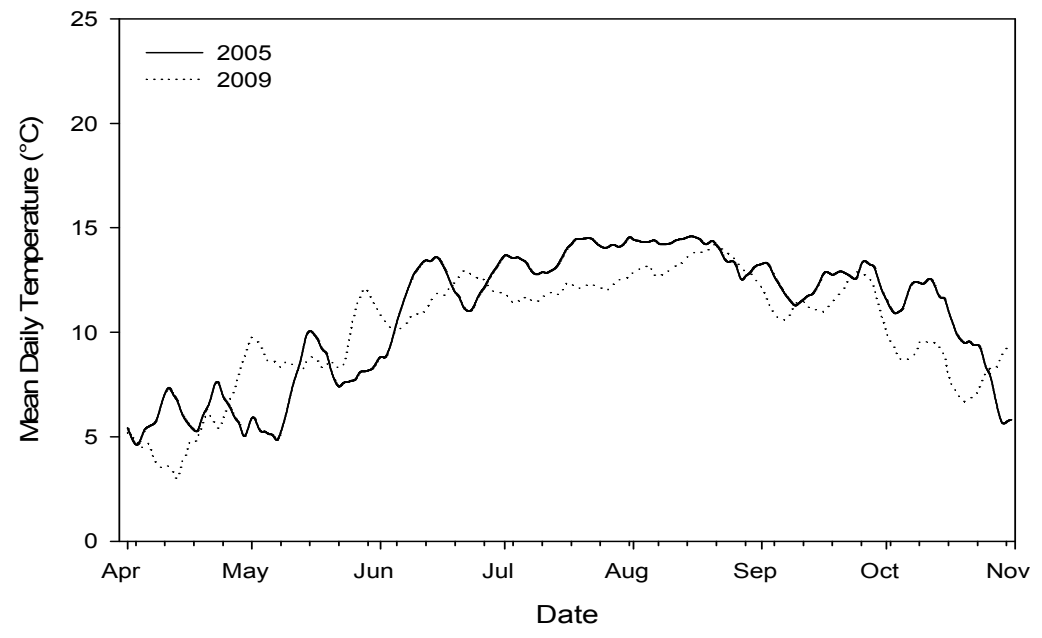

(a)

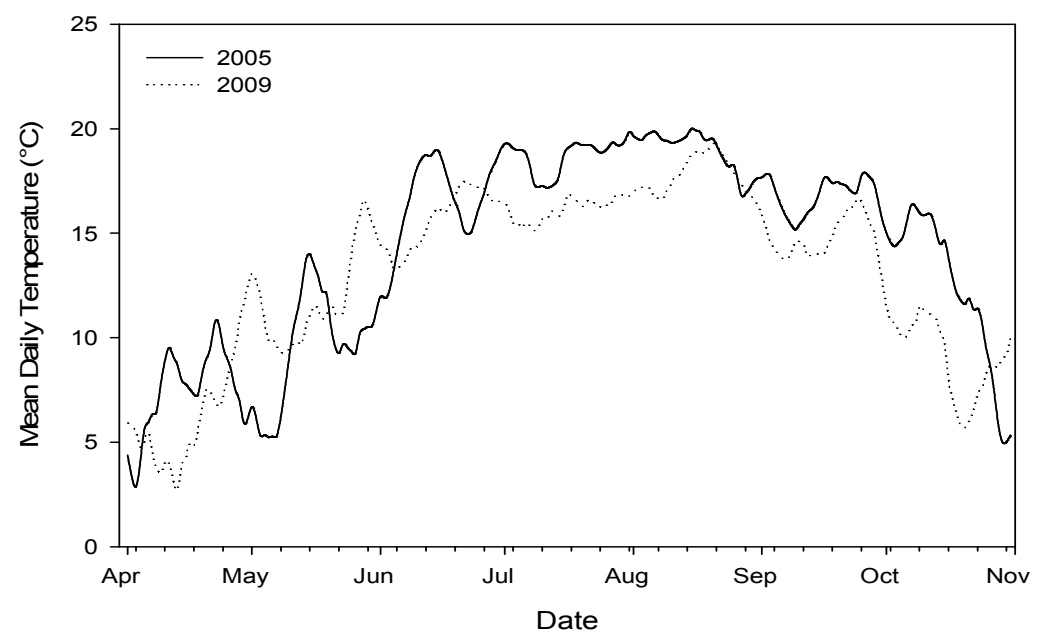

(c)

Figure 7. Mean daily water temperature $\left({ }^{\circ} \mathrm{C}\right)$ for a good year (2009) and bad year (2005) in a (a) small tributary (b) large tributary (c) cool mainstem and (d) warm mainstem from April 1 - October 31.

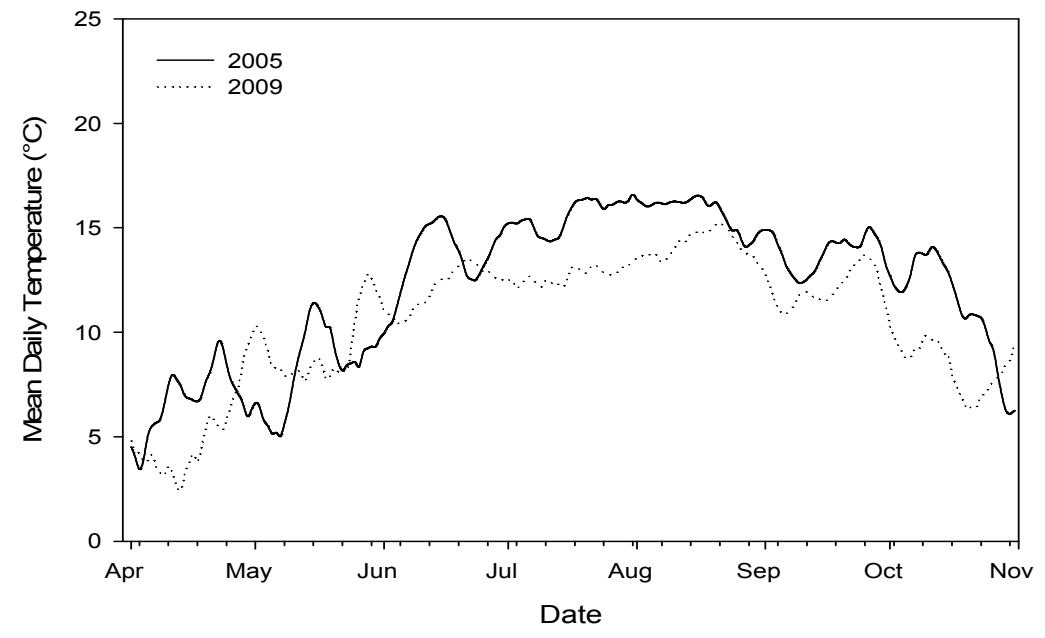

(b)

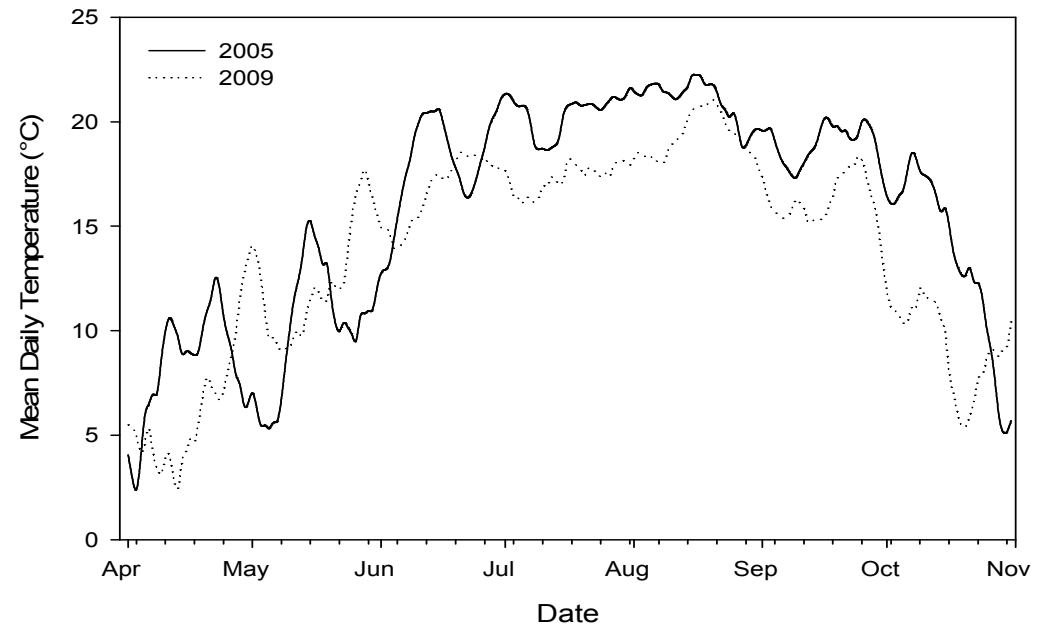

(d) 


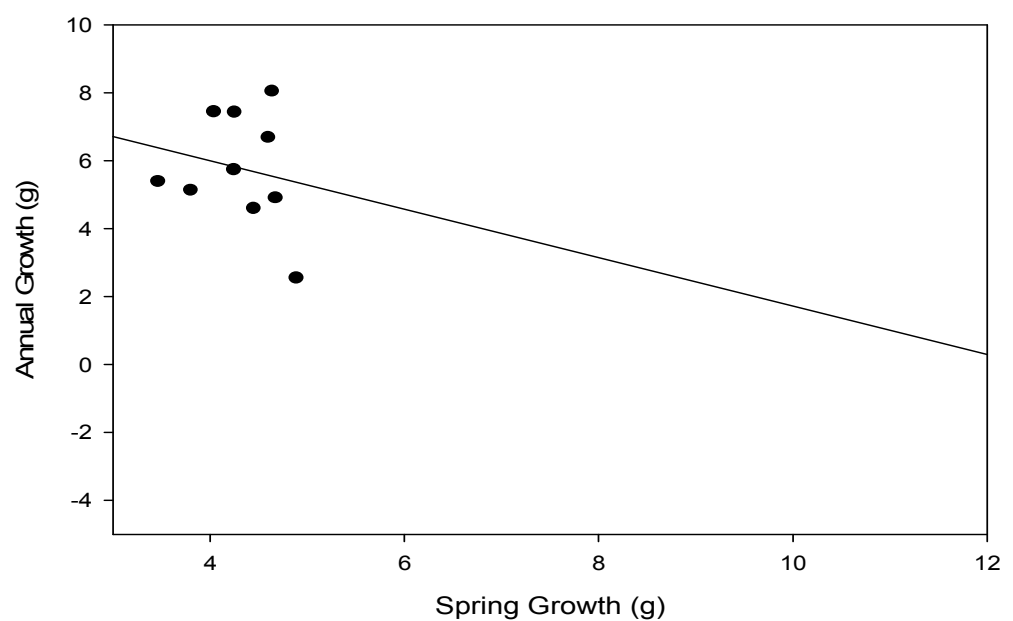

(a)

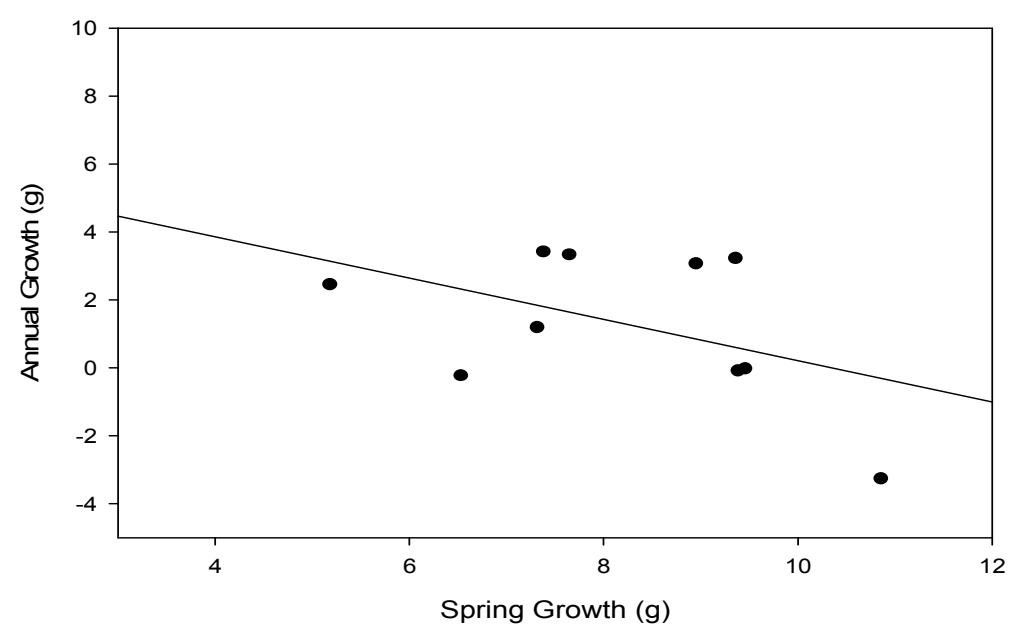

(c)

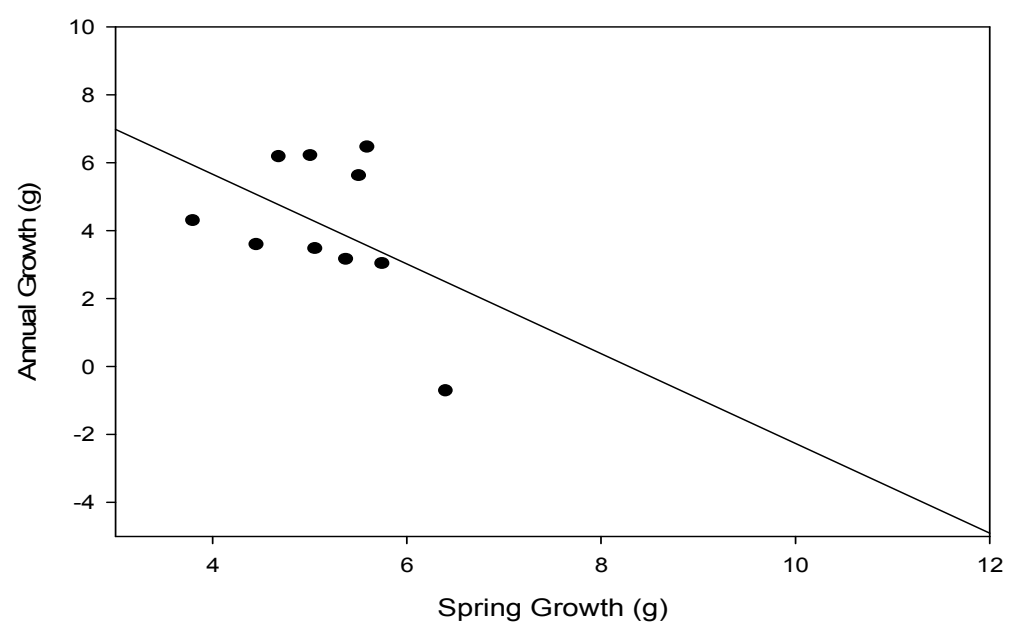

(b)

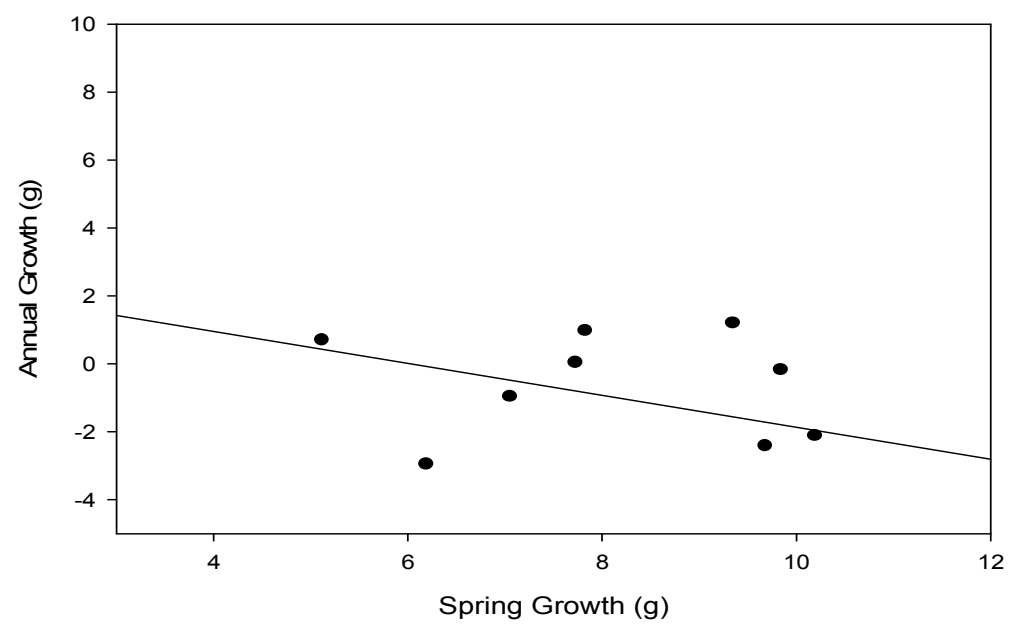

(d)

Figure 8. Correlation between spring and annual growth for a $10 \mathrm{~g}$ brook trout in a (a) small tributary $\left(\mathrm{R}^{2}=0.04\right)(\mathrm{b})$ large tributary $\left(\mathrm{R}^{2}=0.20\right)$ (c) cool mainstem $\left(\mathrm{R}^{2}=0.22\right)$ and $(\mathrm{d})$ warm mainstem $\left(\mathrm{R}^{2}=0.18\right)$. 


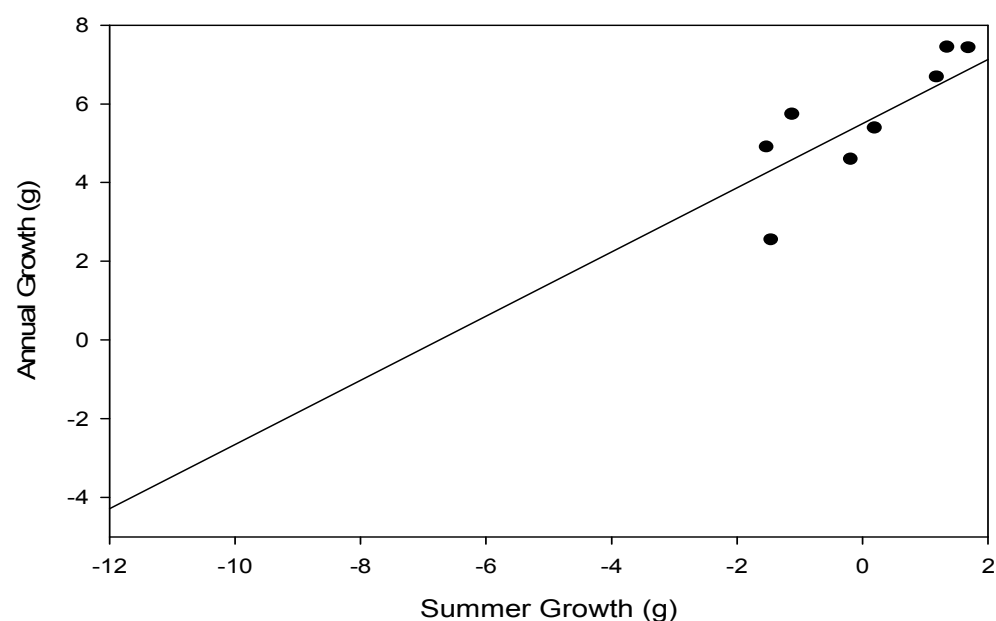

(a)

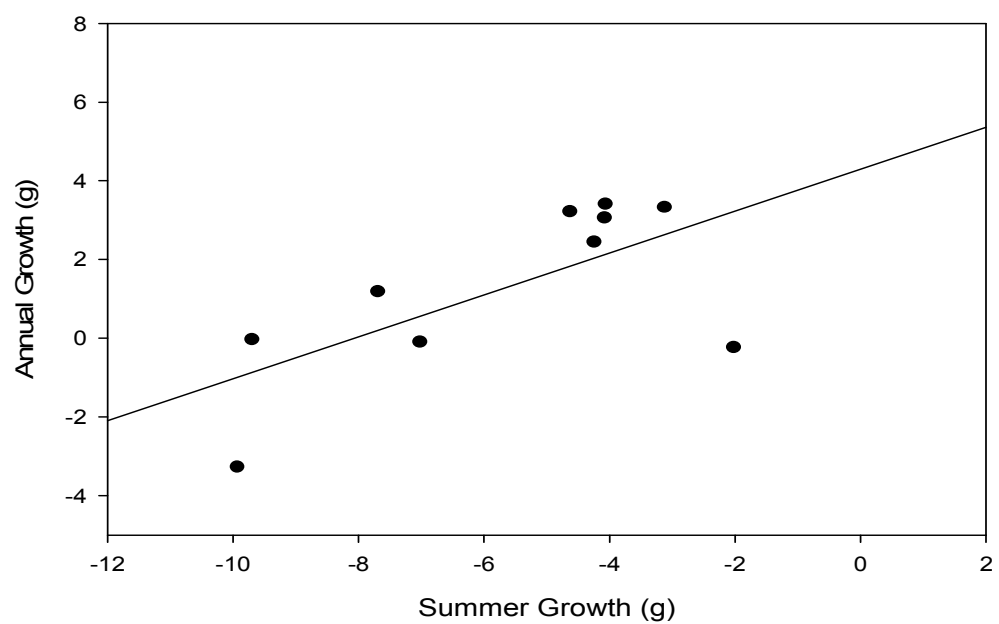

(c)

Figure 9. Correlation between summer and annual growth for a $10 \mathrm{~g}$ brook trout in a (a) small tributary $\left(\mathrm{R}^{2}=0.45\right)(\mathrm{b})$ large tributary $\left(\mathrm{R}^{2}=0.59\right)$ (c) cool mainstem $\left(\mathrm{R}^{2}=0.44\right)$ and $(\mathrm{d})$ warm mainstem $\left(\mathrm{R}^{2}=0.43\right)$.

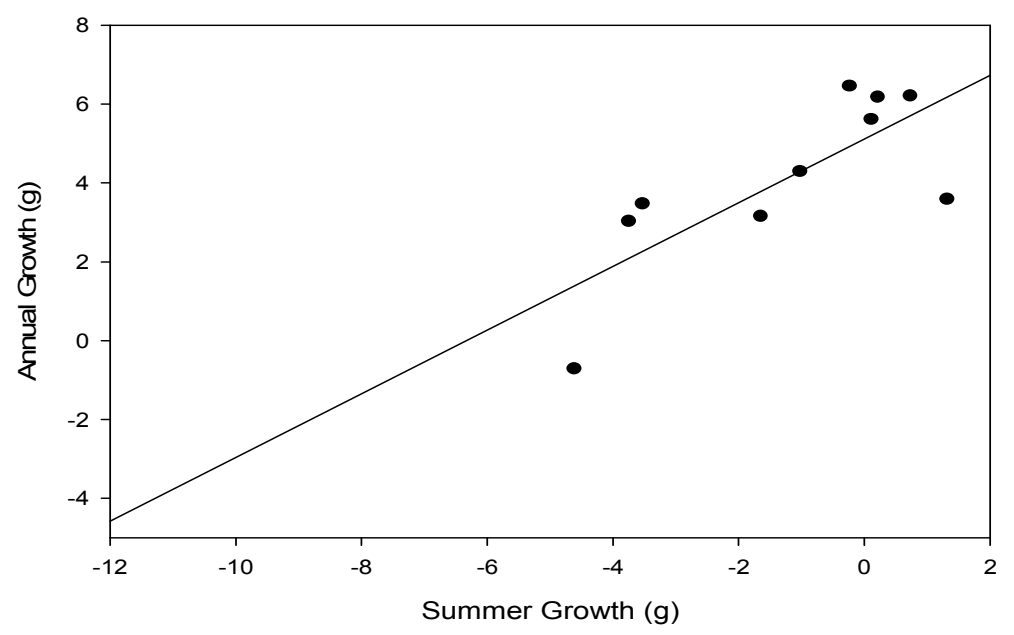

(b)

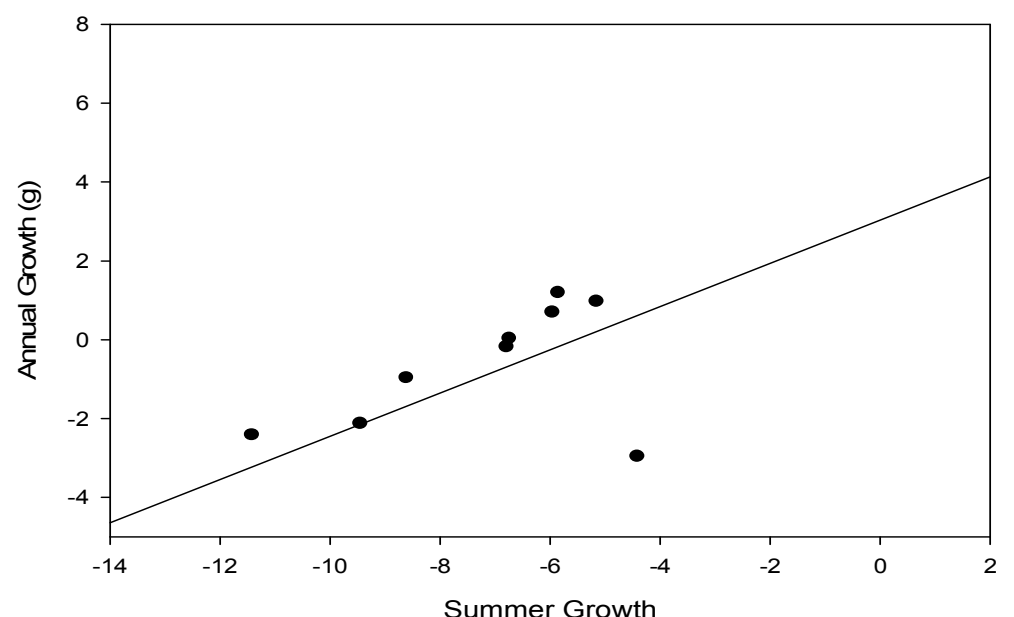

(d) 


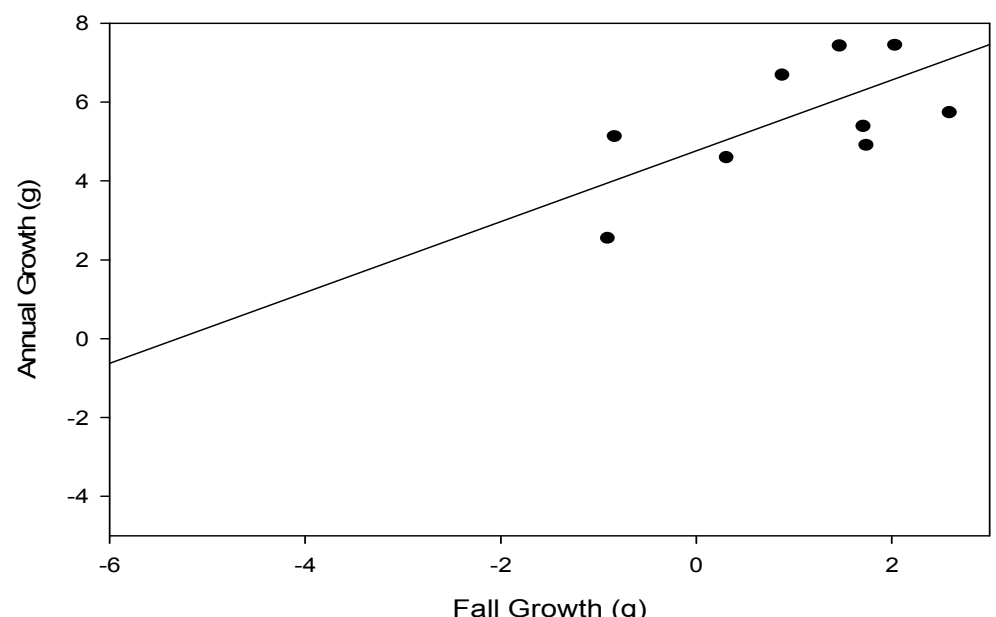

(a)

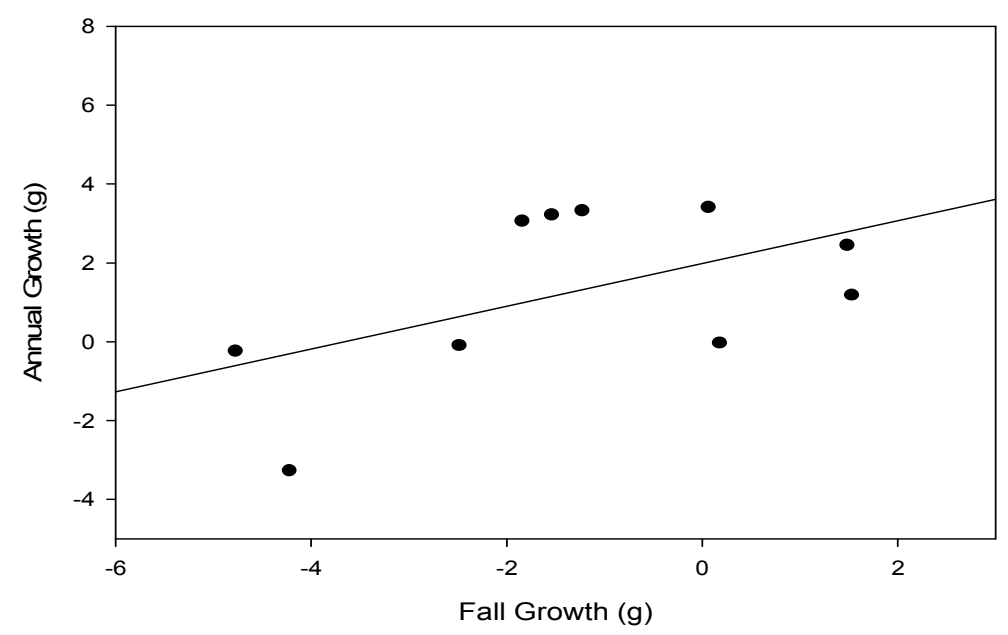

(c)

Figure 10. Correlation between fall and annual growth for a $10 \mathrm{~g}$ brook trout $=0.35)$ (c) cool mainstem $\left(\mathrm{R}^{2}=0.28\right)$ and (d) warm mainstem $\left(\mathrm{R}^{2}=0.36\right)$.

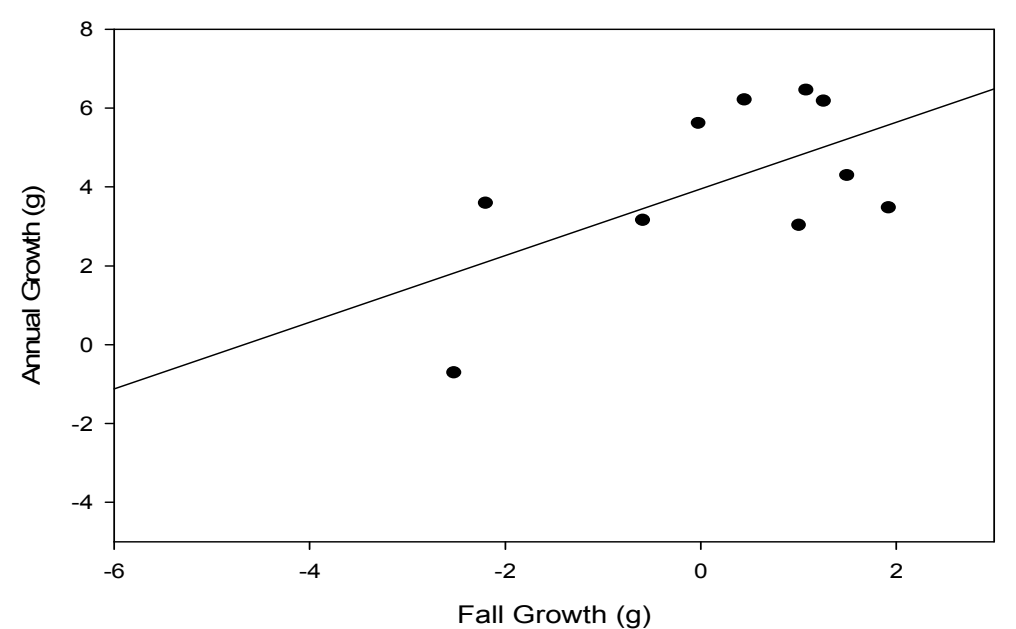

(b)

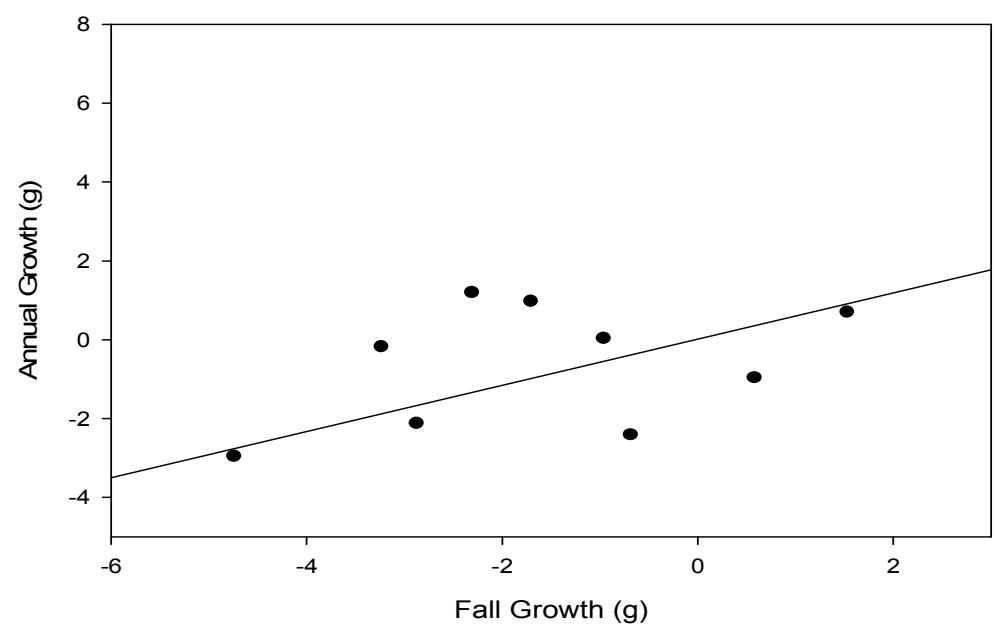

(d) 


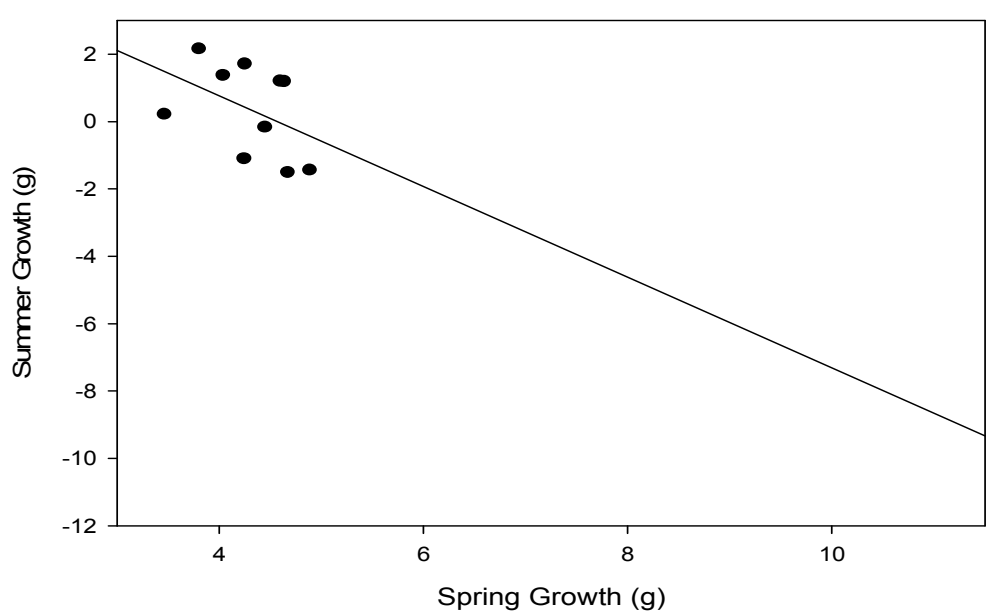

(a)

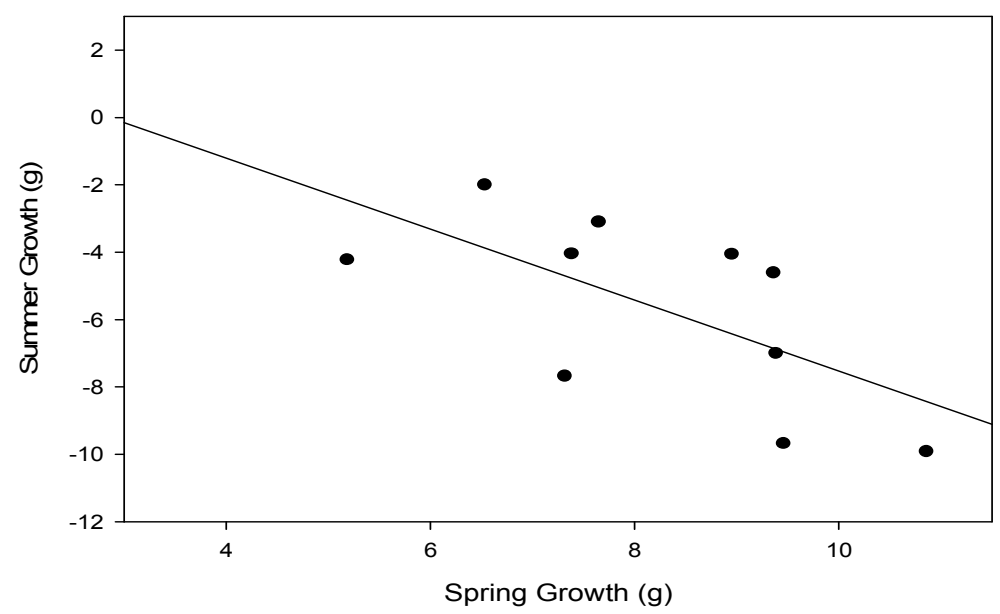

(c)

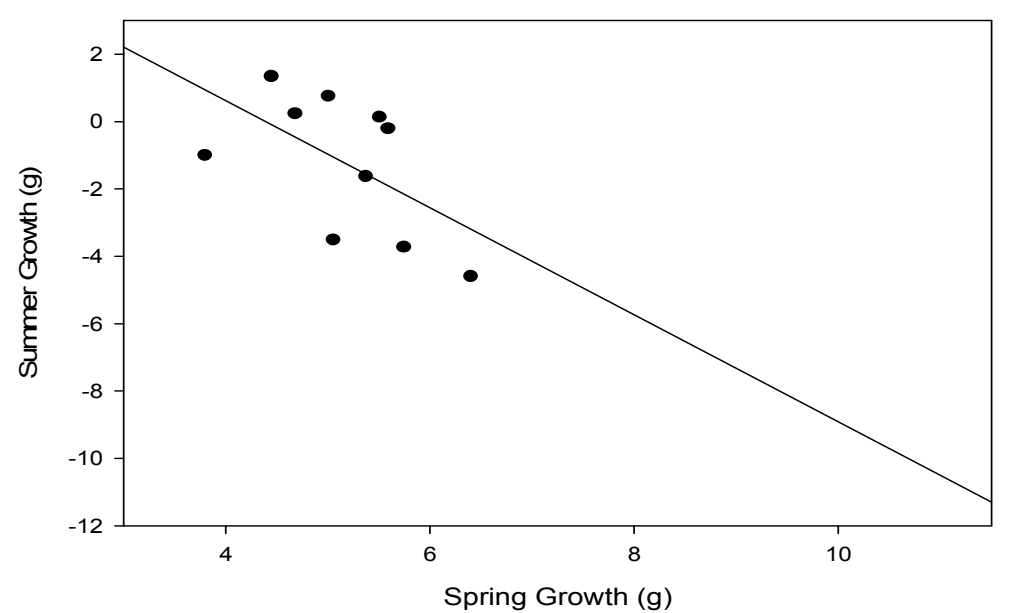

(b)

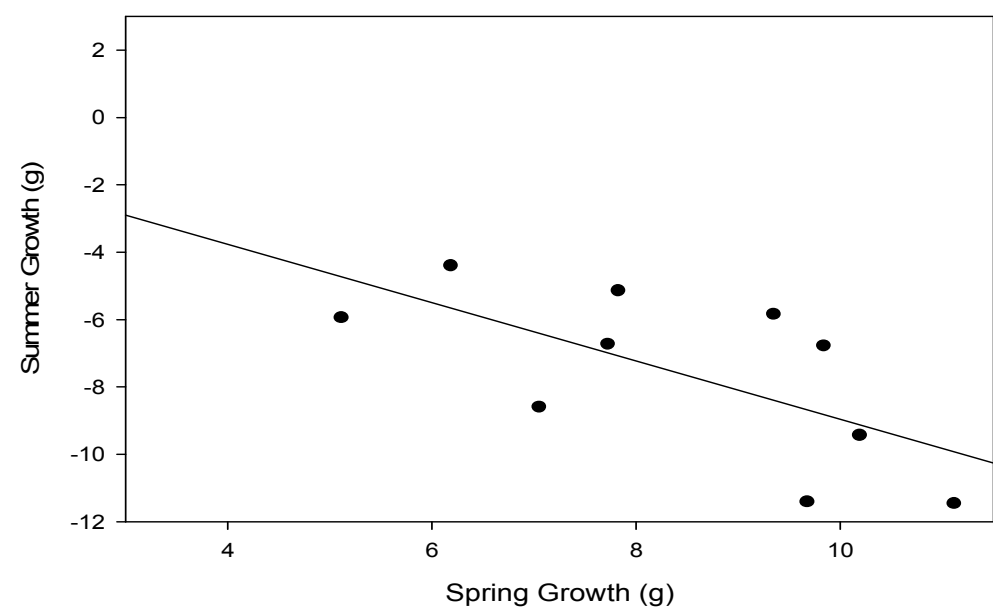

(d)

Figure 11. Correlation between spring and summer growth for a $10 \mathrm{~g}$ brook trout in a (a) small tributary $\left(\mathrm{R}^{2}=0.19\right)(\mathrm{b})$ large tributary $\left(\mathrm{R}^{2}=0.32\right)$ (c) cool mainstem $\left(\mathrm{R}^{2}=0.41\right)$ and $(\mathrm{d})$ warm mainstem $\left(\mathrm{R}^{2}=0.44\right)$. 


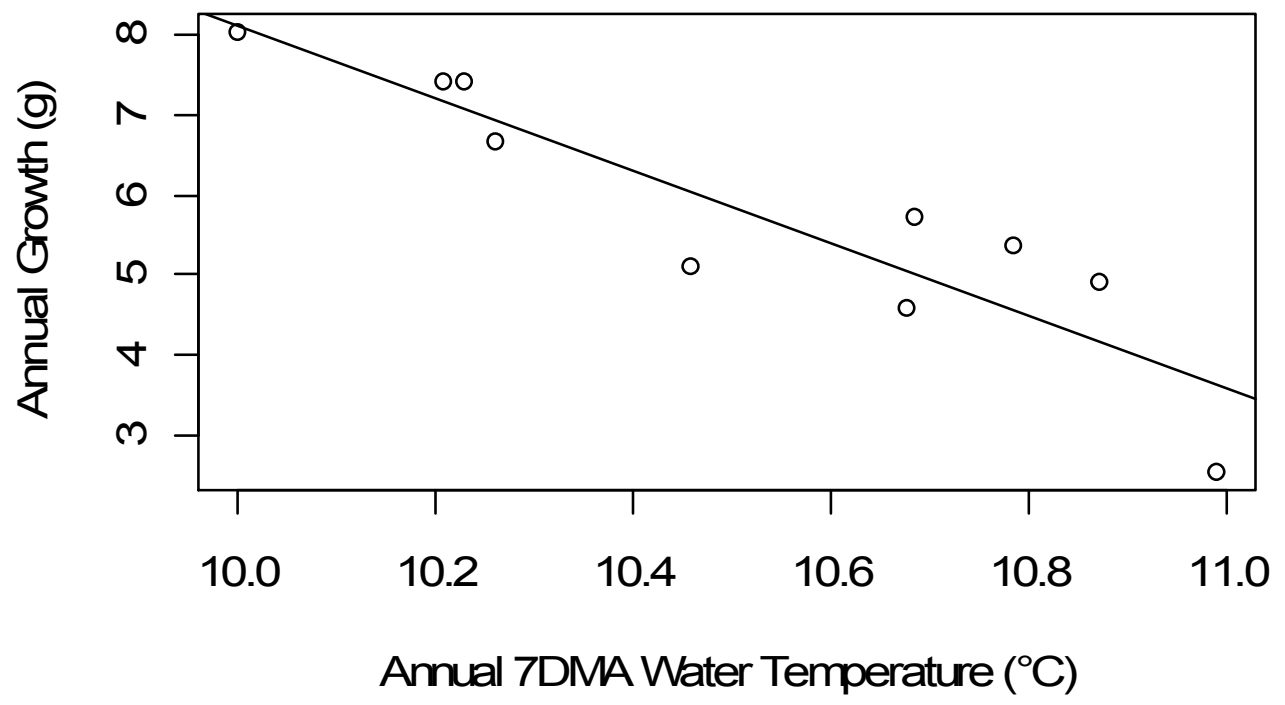

Figure 12. Correlation between annual 7DMA water temperature $\left({ }^{\circ} \mathrm{C}\right)$ and annual growth (g) for a $10 \mathrm{~g}$ brook trout in a small tributary $\left(\mathrm{R}^{2}=0.83\right)$.

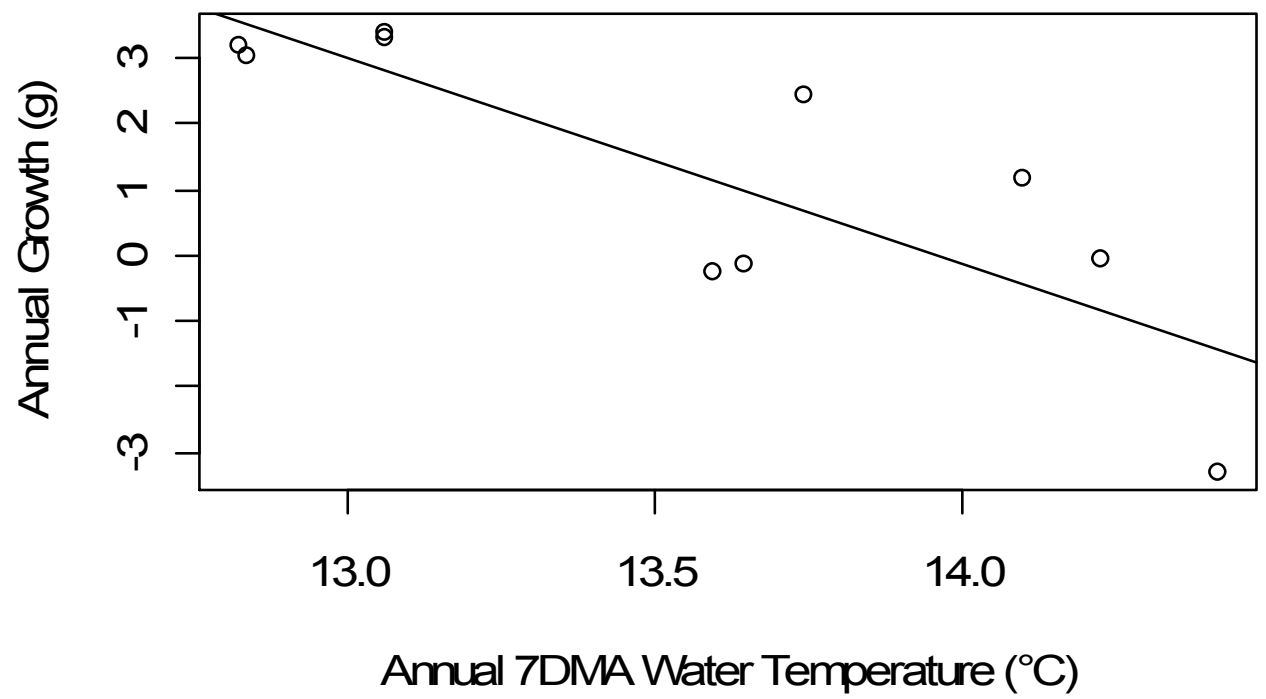

Figure 13. Correlation between annual 7DMA water temperature $\left({ }^{\circ} \mathrm{C}\right)$ and annual growth (g) for a $10 \mathrm{~g}$ brook trout in a cool mainstem $\left(\mathrm{R}^{2}=0.68\right)$. 


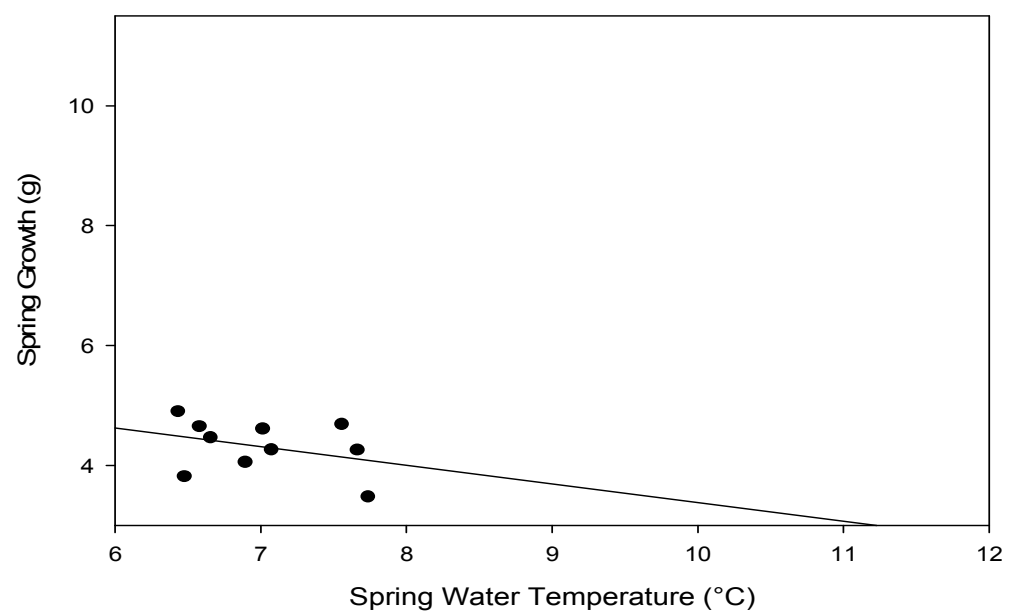

(a)

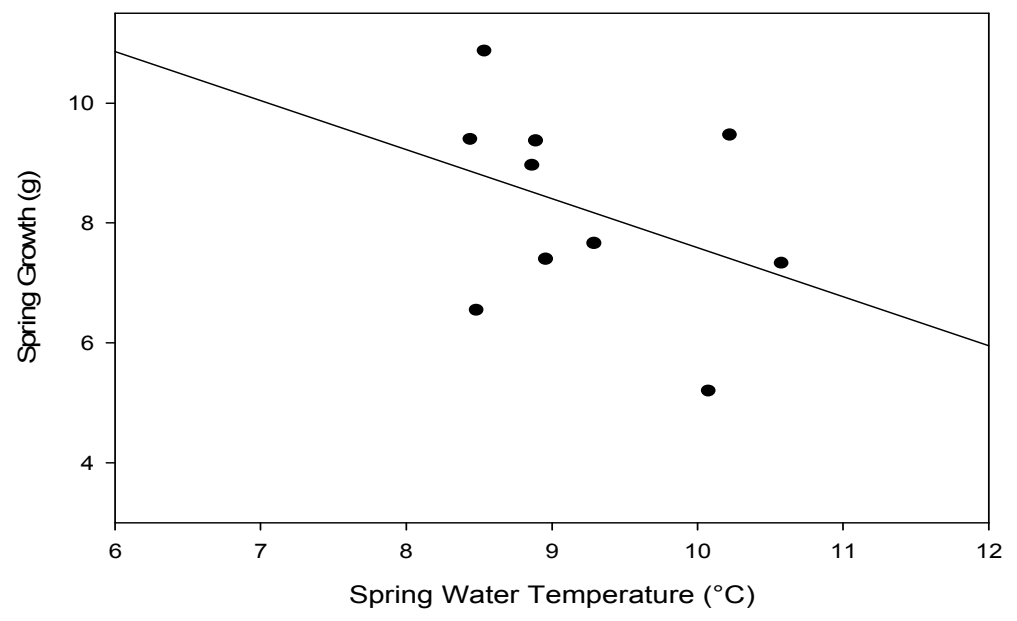

(c)

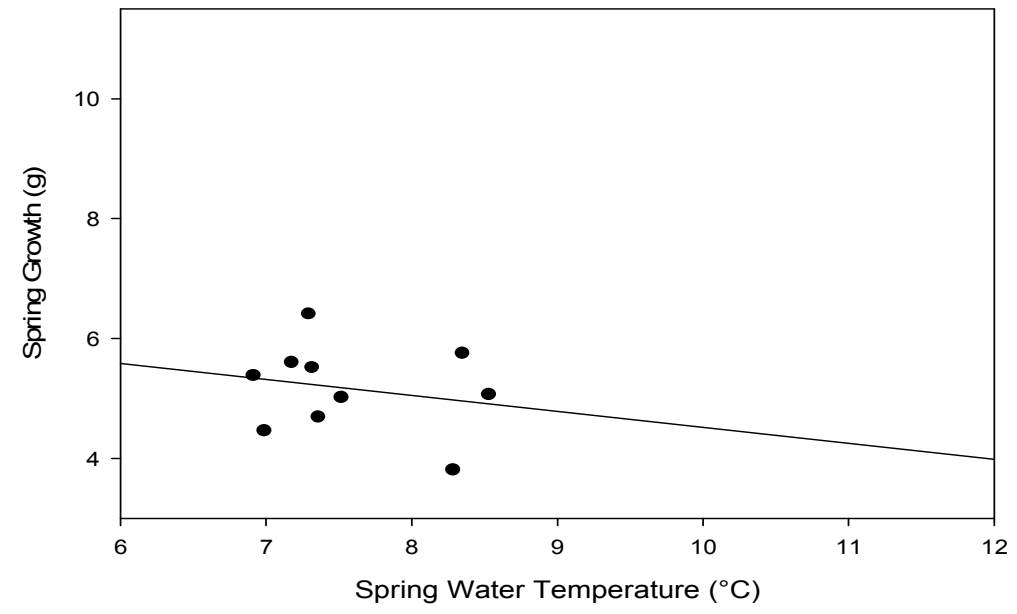

(b)

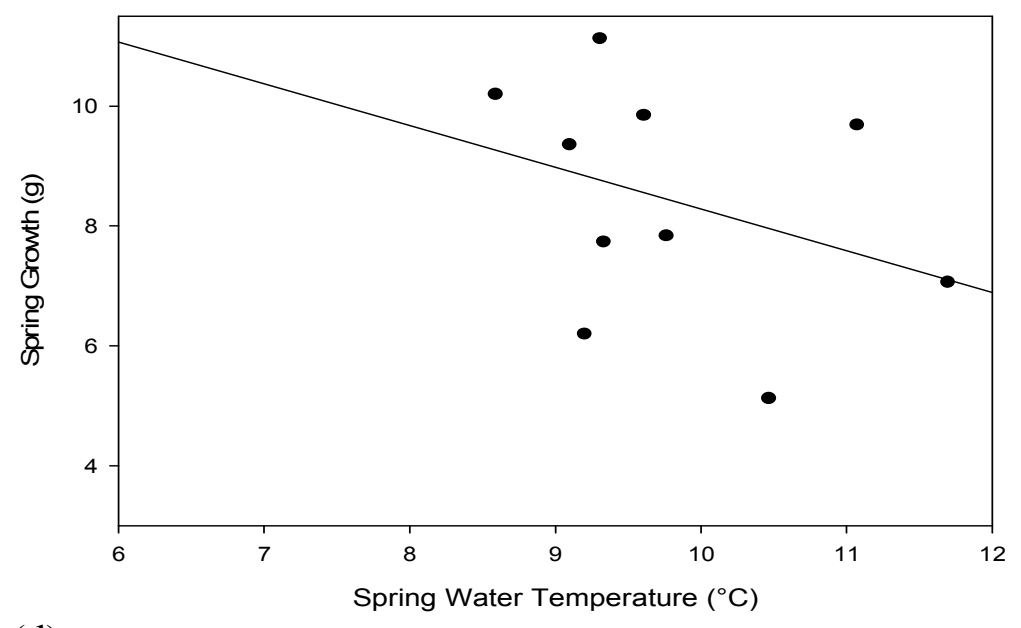

(d)

Figure 14. Correlation of spring 7DMA water temperature $\left({ }^{\circ} \mathrm{C}\right)$ and growth $(\mathrm{g})$ for a $10 \mathrm{~g}$ brook trout in a (a) small tributary $\left(\mathrm{R}^{2}=0.12\right)$, (b) large tributary $\left(\mathrm{R}^{2}=0.05\right)$, (c) cool mainstem $\left(\mathrm{R}^{2}=0.14\right)$, and $(\mathrm{d})$ warm mainstem $\left(\mathrm{R}^{2}=0.12\right)$. 


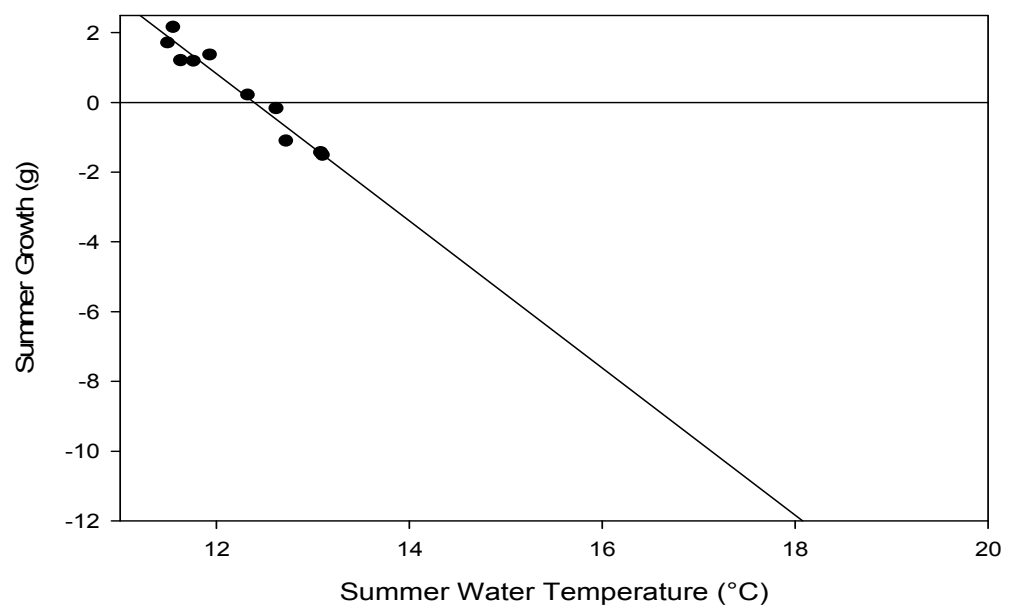

(a)

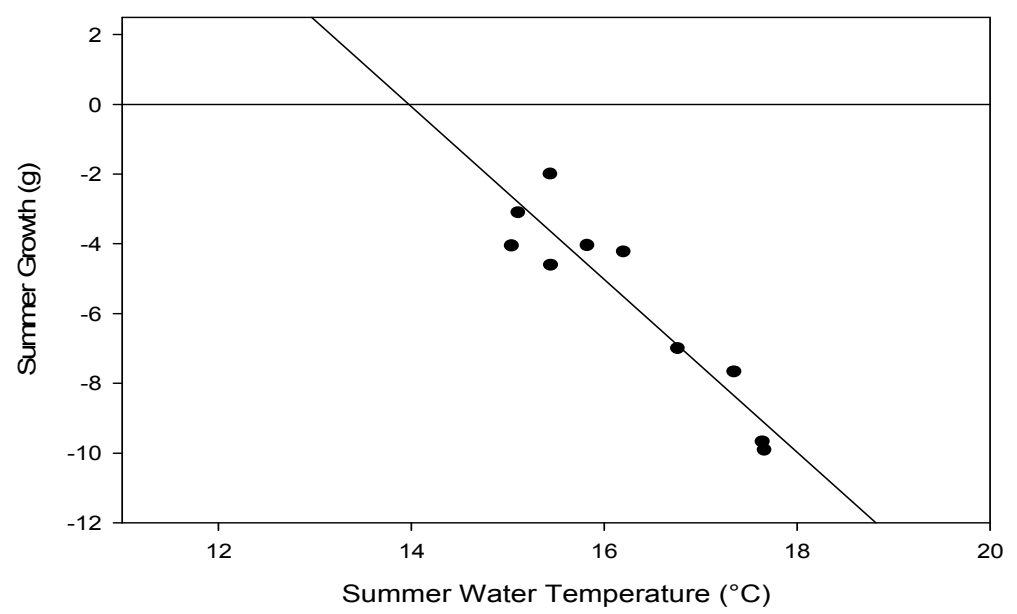

(c)

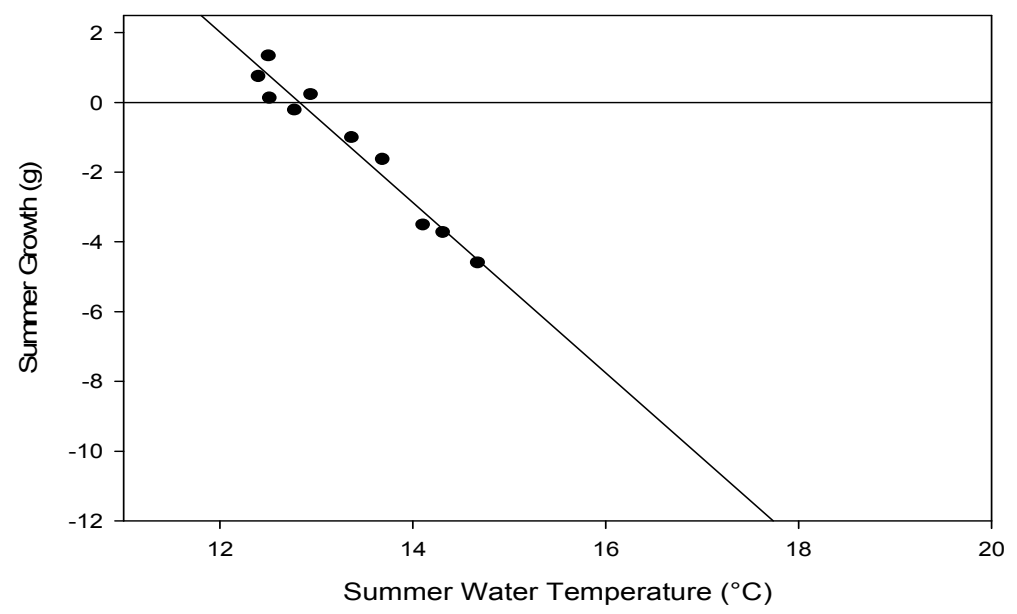

(b)

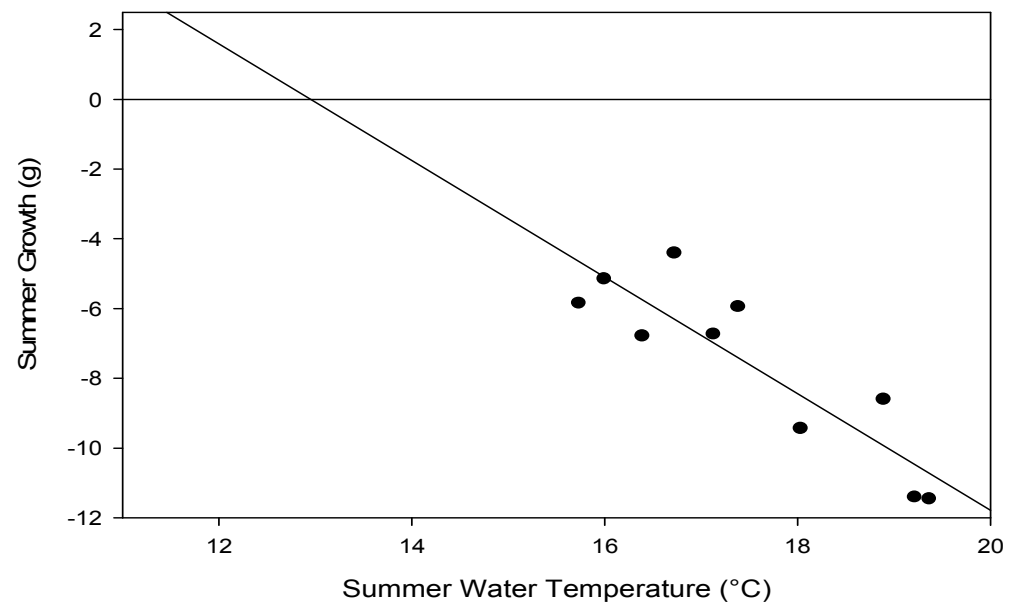

(d)

Figure 15. Correlation of summer 7DMA water temperature $\left({ }^{\circ} \mathrm{C}\right)$ and growth $(\mathrm{g})$ for a $10 \mathrm{~g}$ brook trout in a (a) small tributary $\left(\mathrm{R}^{2}=0.95\right)$, (b) large tributary $\left(\mathrm{R}^{2}=0.96\right)$, (c) cool mainstem $\left(\mathrm{R}^{2}=0.87\right)$, and $(\mathrm{d})$ warm mainstem $\left(\mathrm{R}^{2}=0.78\right)$. 


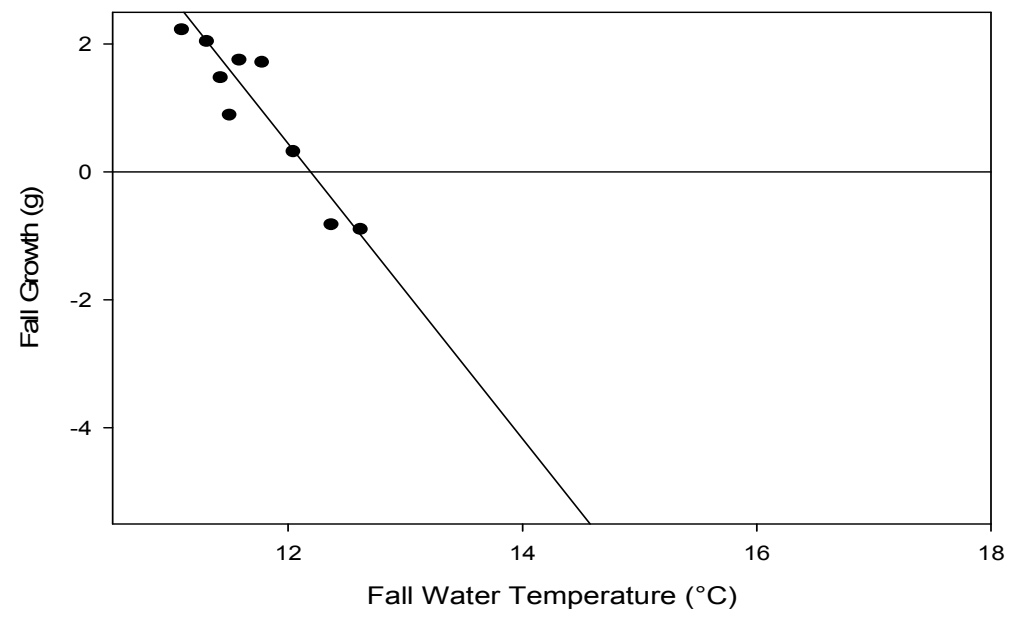

(a)

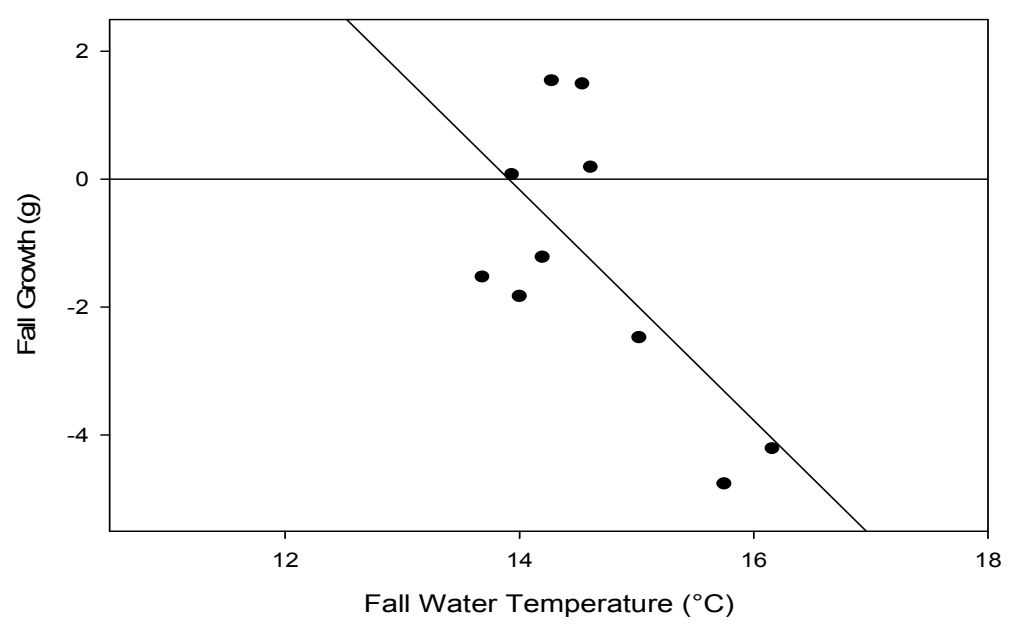

(c)

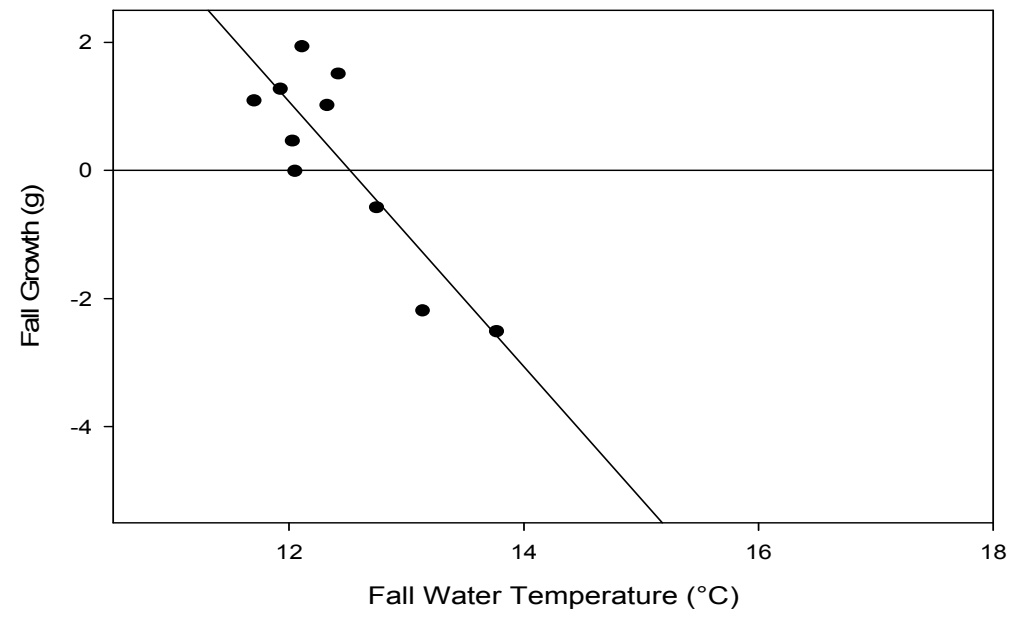

(b)

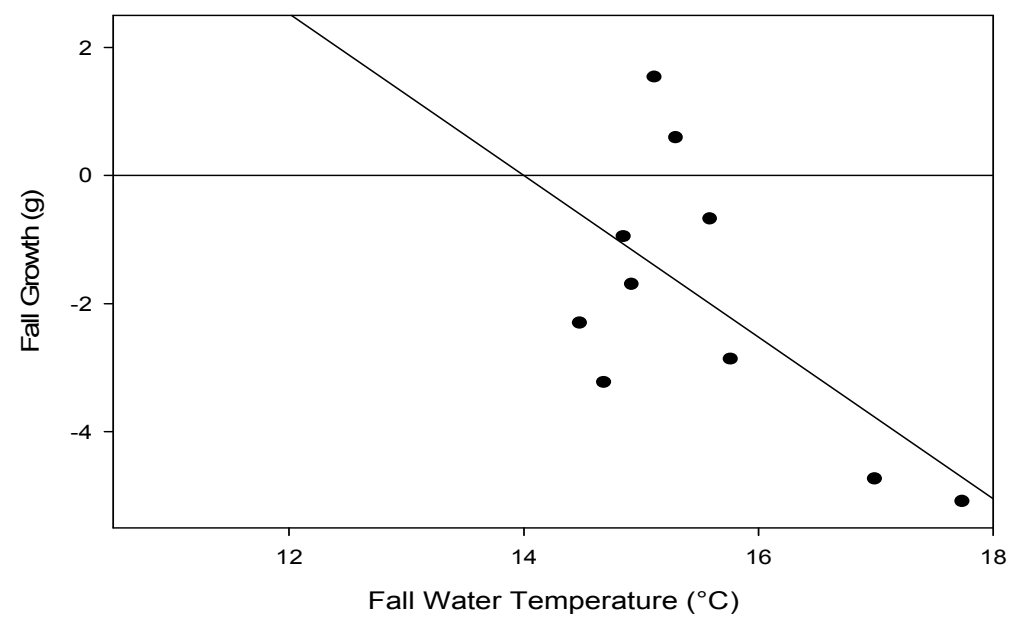

(d)

Figure 16. Correlation of fall 7DMA water temperature $\left({ }^{\circ} \mathrm{C}\right)$ and growth $(\mathrm{g})$ for a $10 \mathrm{~g}$ brook trout in a (a) small tributary $\left(\mathrm{R}^{2}=0.86\right)$, (b) large tributary $\left(\mathrm{R}^{2}=0.73\right)$, (c) cool mainstem $\left(\mathrm{R}^{2}=0.45\right)$, and $(\mathrm{d})$ warm mainstem $\left(\mathrm{R}^{2}=0.38\right)$. 


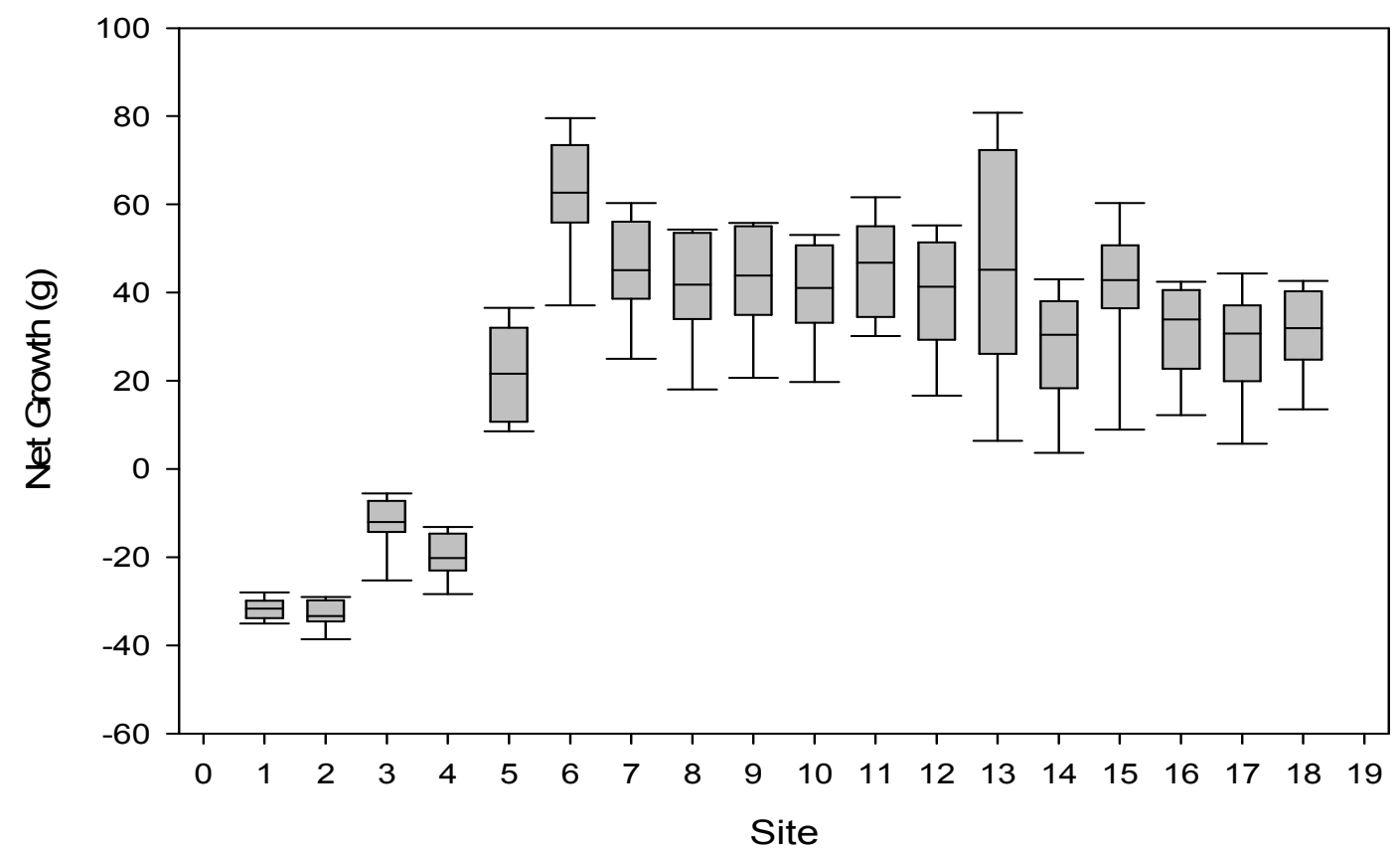

Figure 17. Net growth for $50 \mathrm{~g}$ brook trout at each site location.

\begin{tabular}{lc}
\hline Site & Graph Site \\
\hline Second 2.1 & 1 \\
Second 3.4 & 2 \\
Second 10.4 & 3 \\
Second 15.4 & 4 \\
Shavers 7.5 & 5 \\
Shavers 12.9 & 6 \\
Shavers 20.7 & 7 \\
Shavers 27.9 & 8 \\
Shavers 29.5 & 9 \\
Shavers 31.7 & 10 \\
Shavers 38.7 & 11 \\
Shavers 41.1 & 12 \\
Shavers 43.0 & 13 \\
Shavers 43.8 & 14 \\
Shavers 59.4 & 15 \\
Shavers 65.1 & 16 \\
Shavers 89.1 & 17 \\
Shavers 117.4 & 18 \\
\hline
\end{tabular}




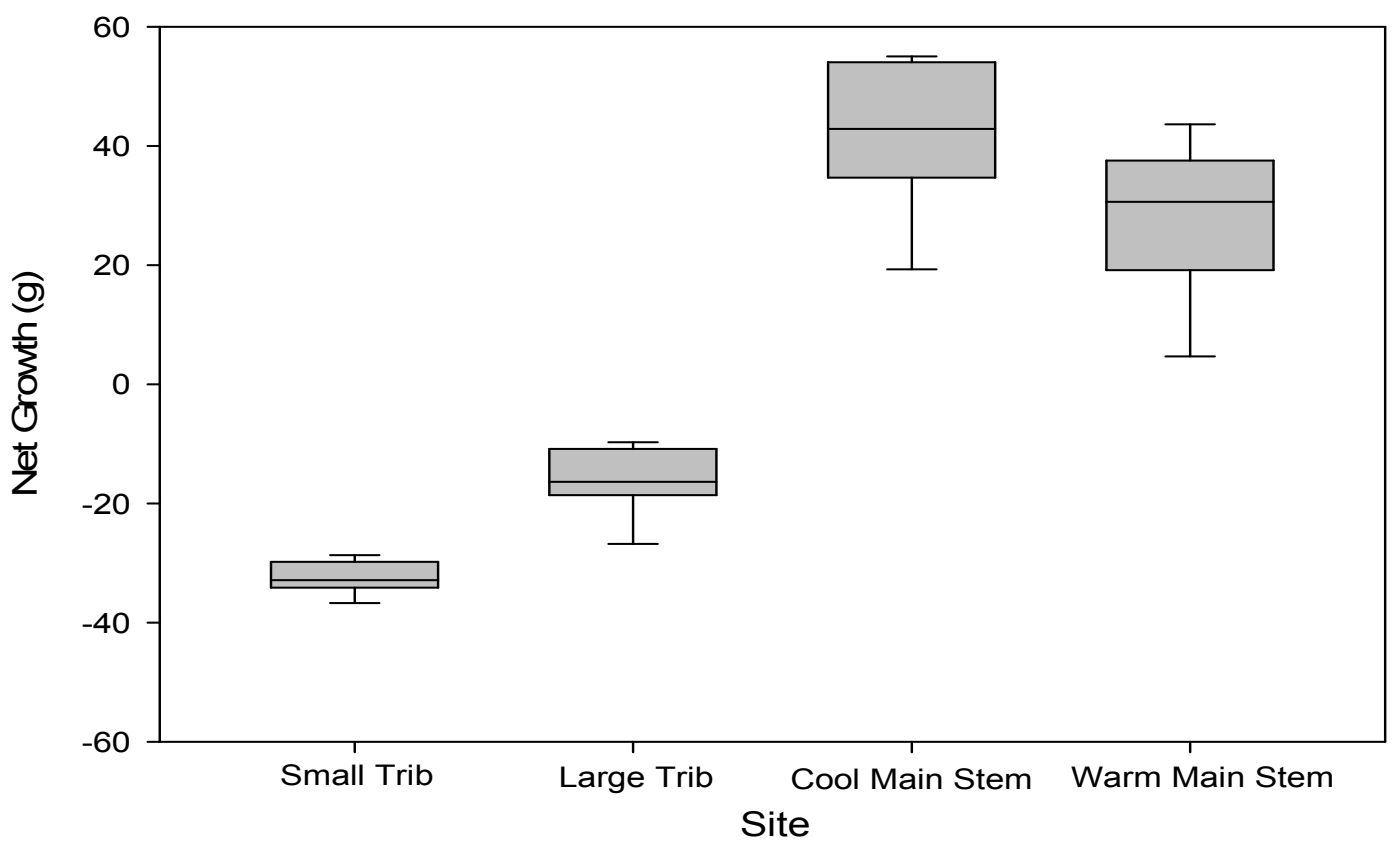

Figure 18. Average yearly net growth $(\mathrm{g})$ for a $50 \mathrm{~g}$ brook trout for each site type from 20012012. 


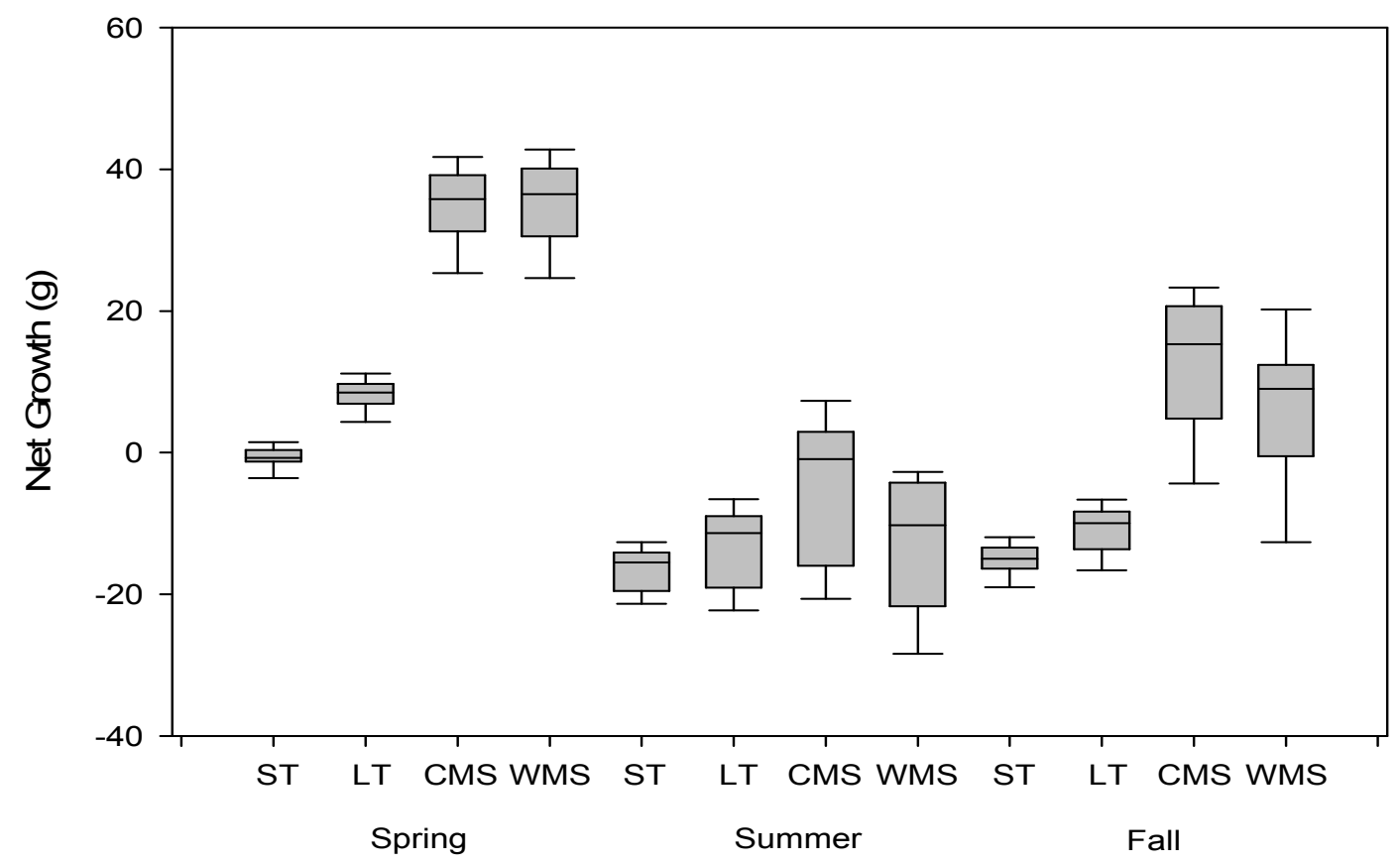

Figure 19. Seasonal and site type net potential growth (g) from 2001-2012 for a 50g brook trout. 


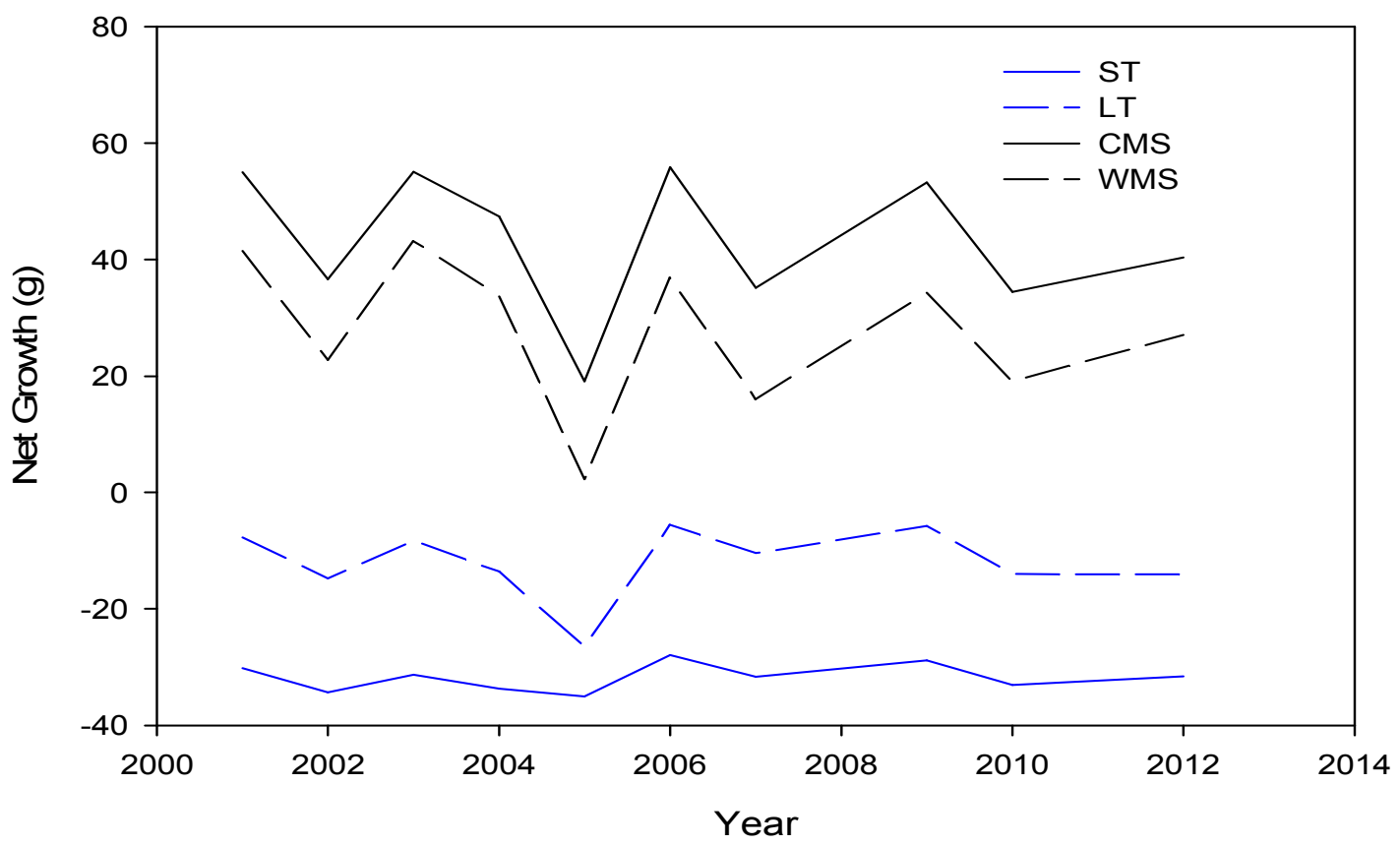

Figure 20. Annual net growth (g) for a 50g brook trout in each site type. 


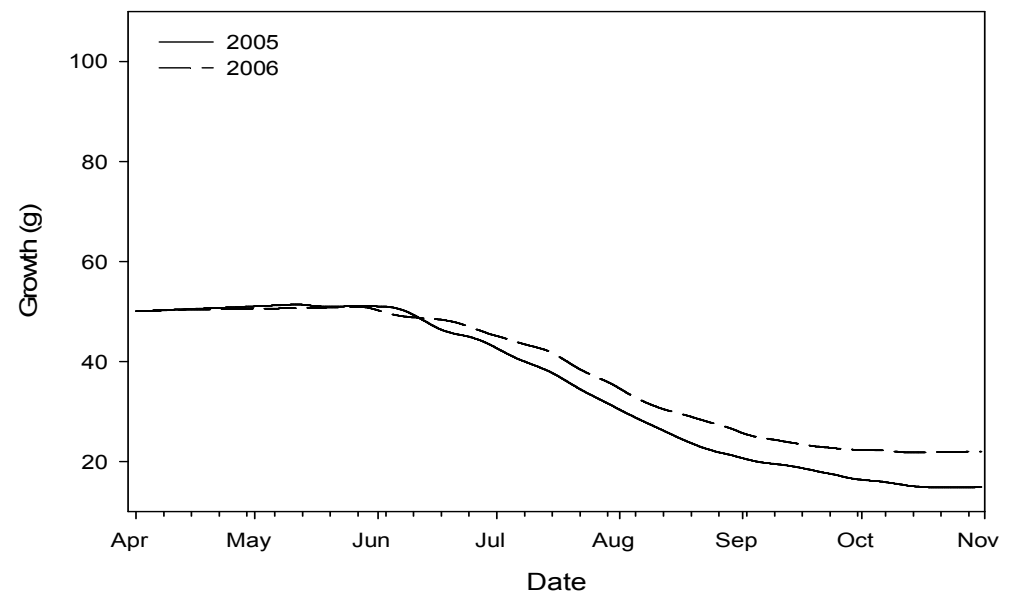

(a)

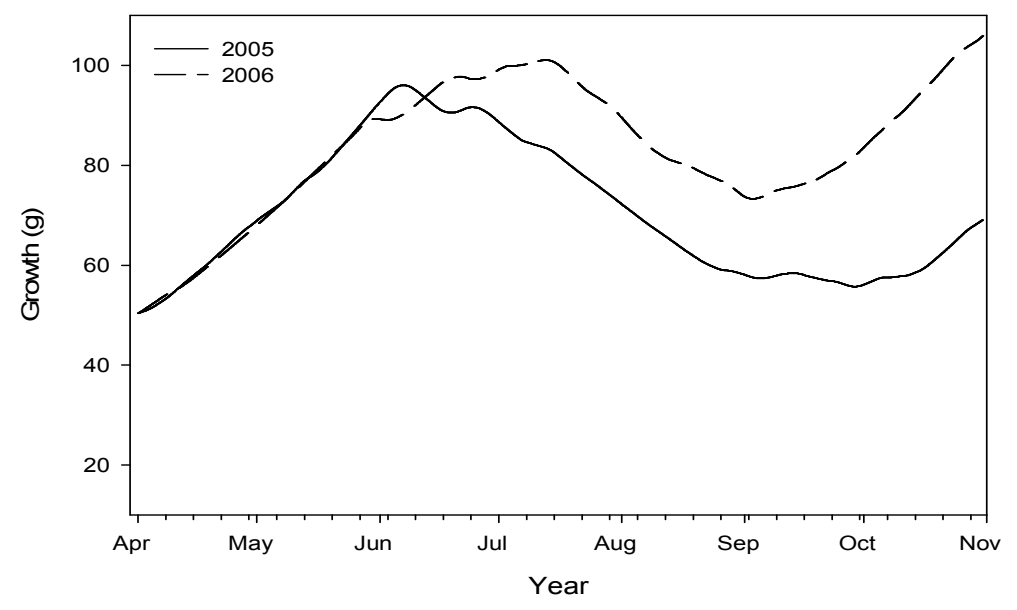

(c)

Figure 21. Good year (2006) and bad year (2005) of growth for a 50g brook trout in a (a) small tributary (b) large tributary (c) cool
mainstem and (d) warm mainstem.

Figure 21. Good year (2006) and bad year (2005) of growth for a 50g brook trout in a (a) small tributary (b) large tributary (c) cool
mainstem and (d) warm mainstem.

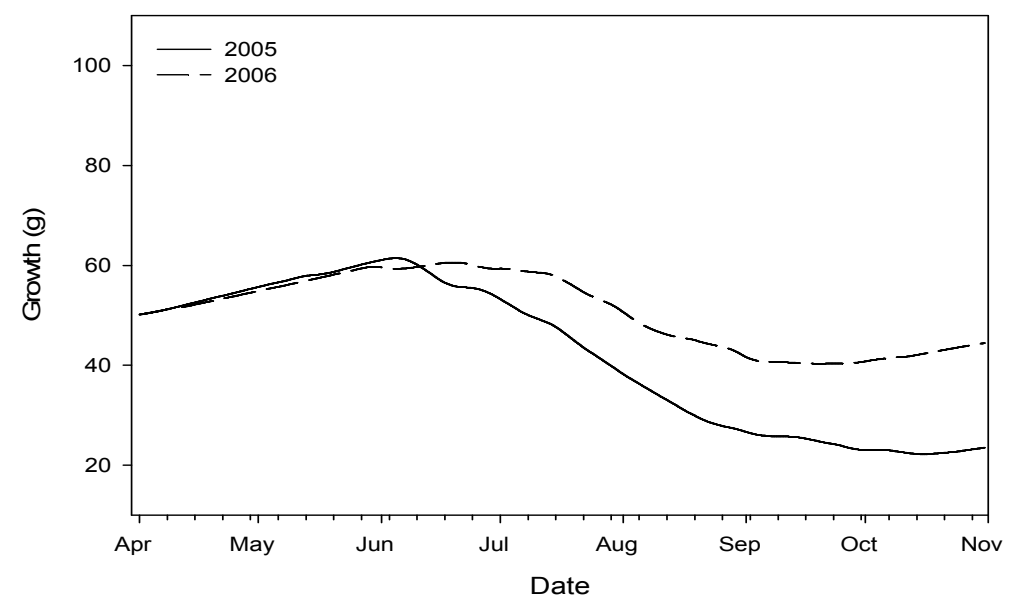

(b)

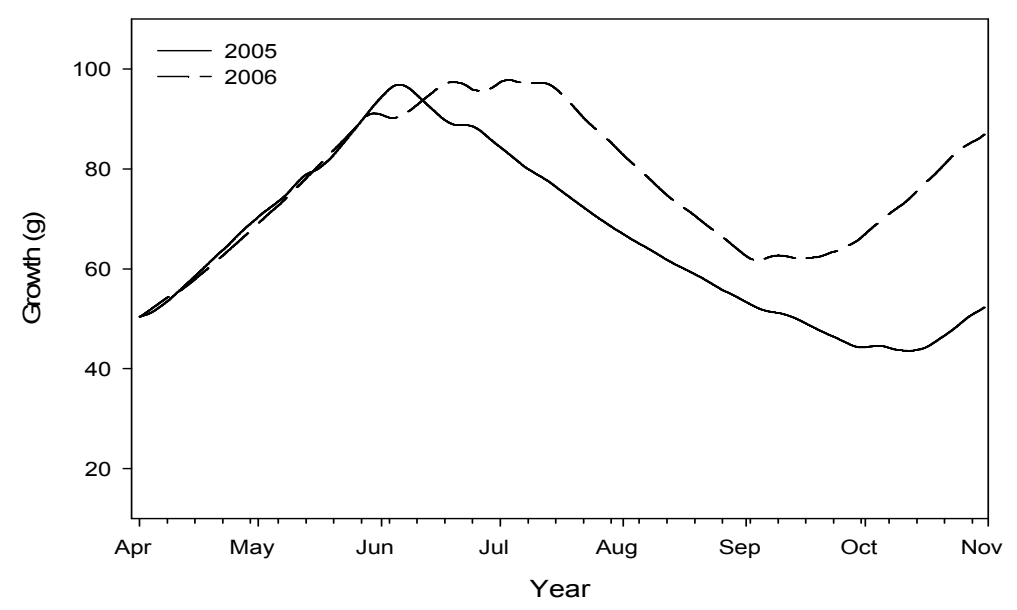

(d) 


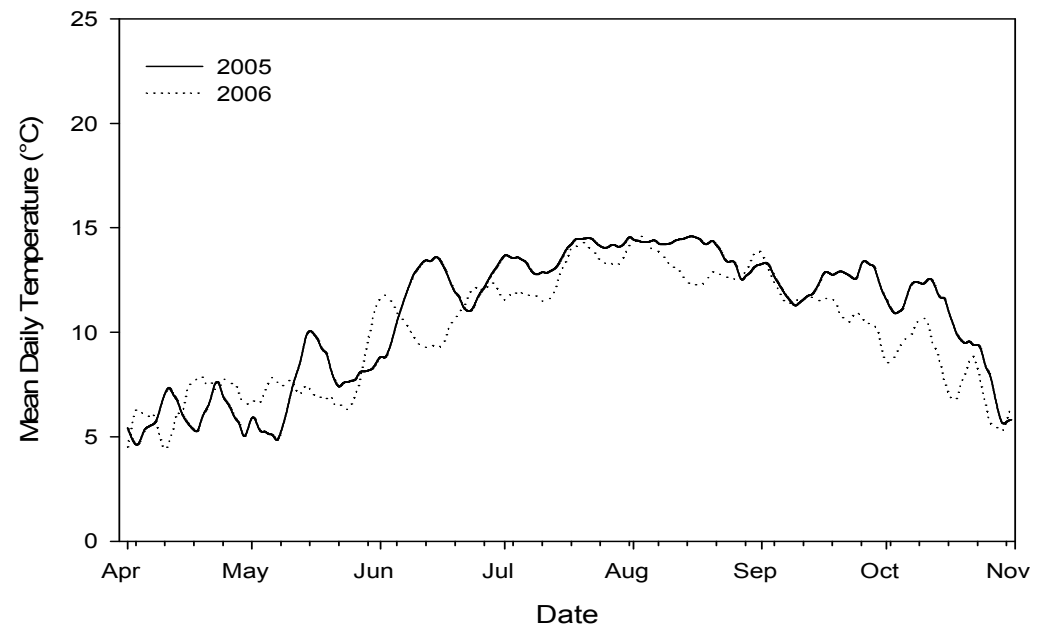

(a)

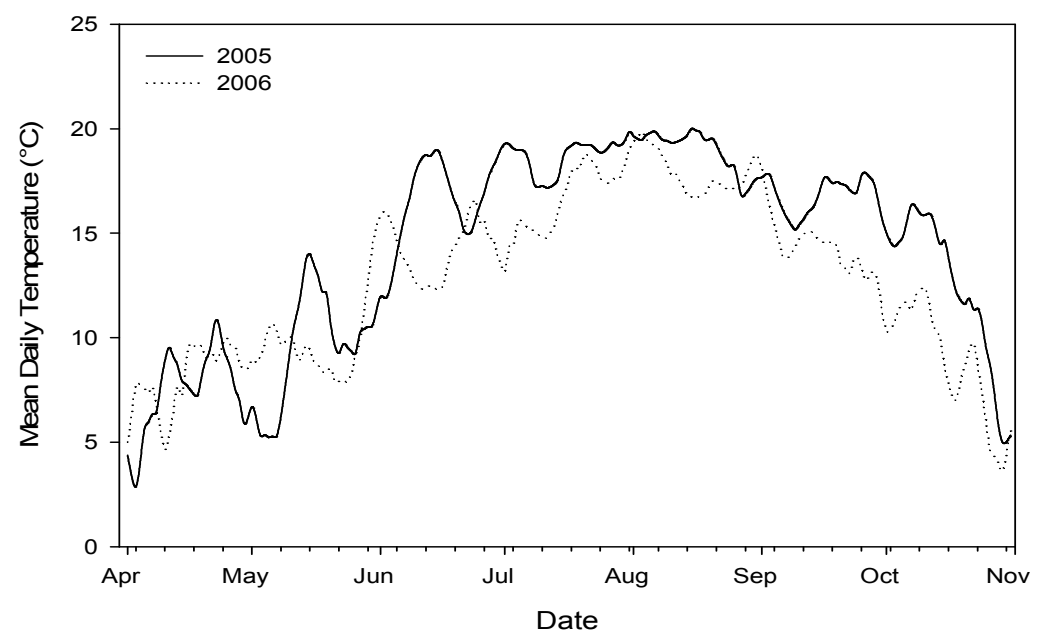

(c)

Figure 22. Mean daily water temperature $\left({ }^{\circ} \mathrm{C}\right)$ for a good year (2006) and bad year (2005) in a (a) small tributary (b) large tributary (c) cool mainstem and (d) warm mainstem from April 1 - October 31.

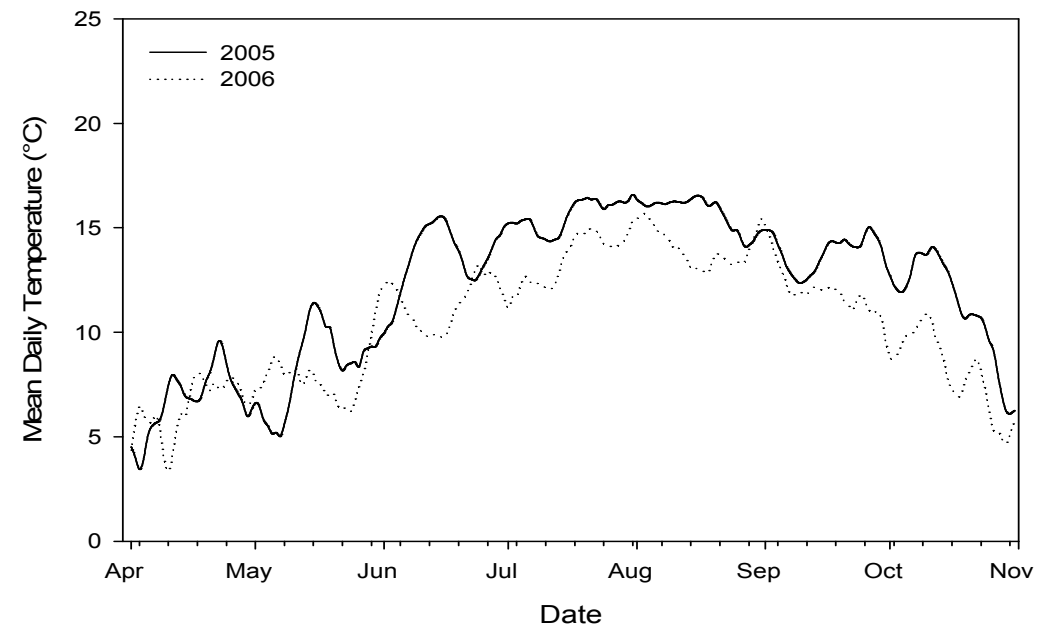

(b)

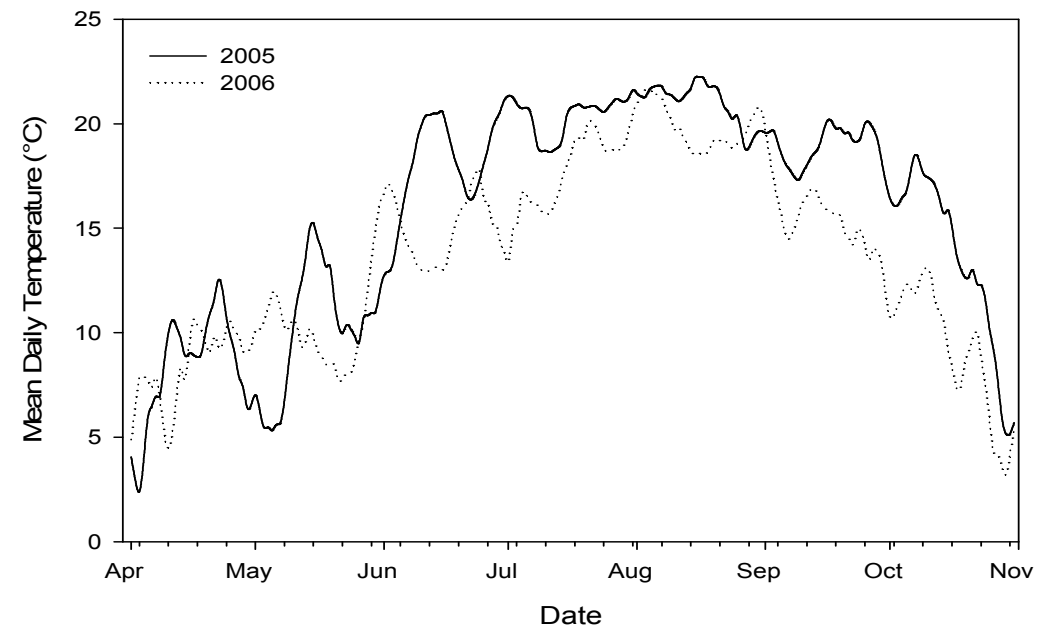

(d) 


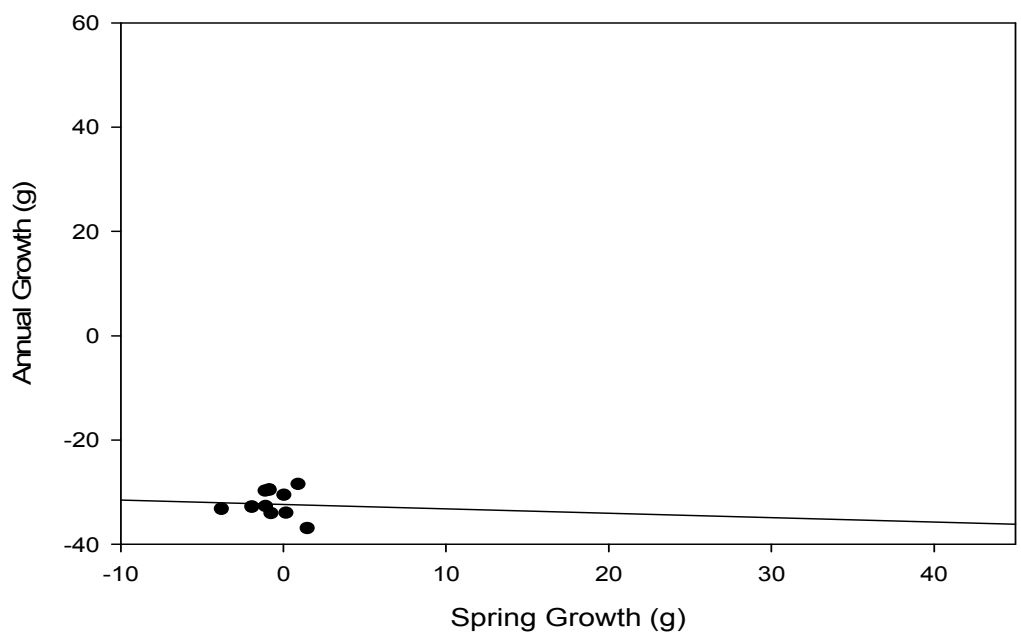

(a)

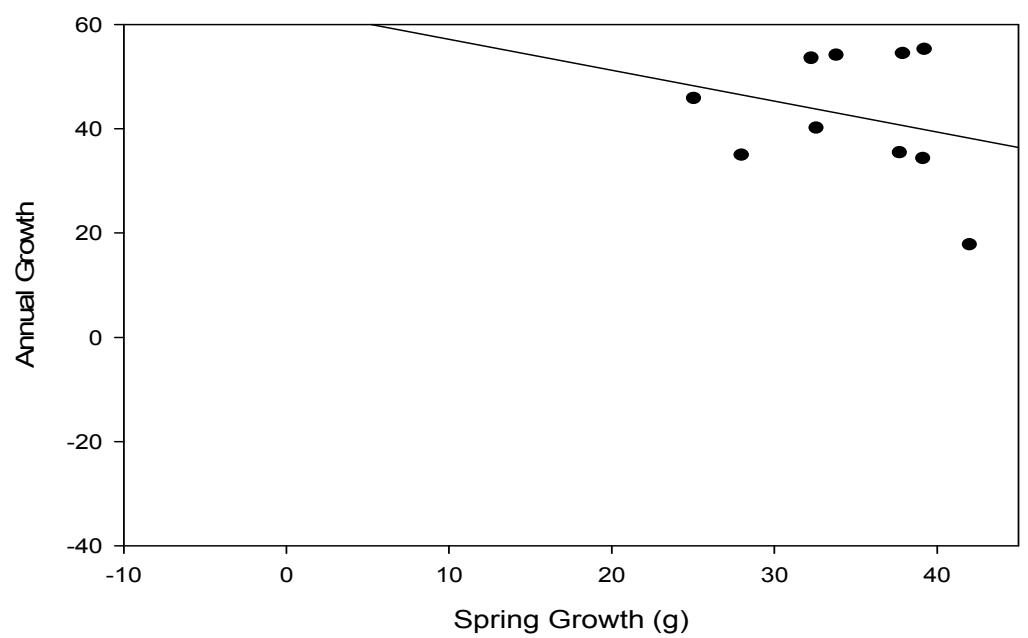

(c)

Figure 23. Correlation between spring and annual growth (g) for a $50 \mathrm{~g}$ brook trout in a (a) small tributary $\left(\mathrm{R}^{2}=0.00\right)(\mathrm{b})$ large tributary $\left(\mathrm{R}^{2}=0.06\right)(\mathrm{c})$ cool mainstem $\left(\mathrm{R}^{2}=0.07\right)(\mathrm{d})$ warm mainstem $\left(\mathrm{R}^{2}=0.04\right)$.

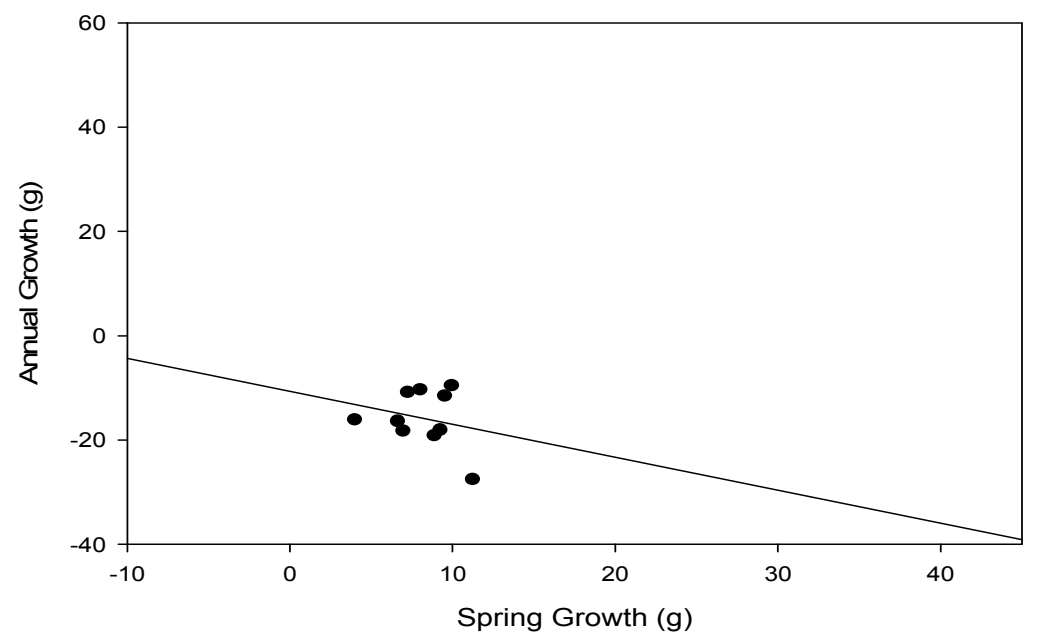

(b)

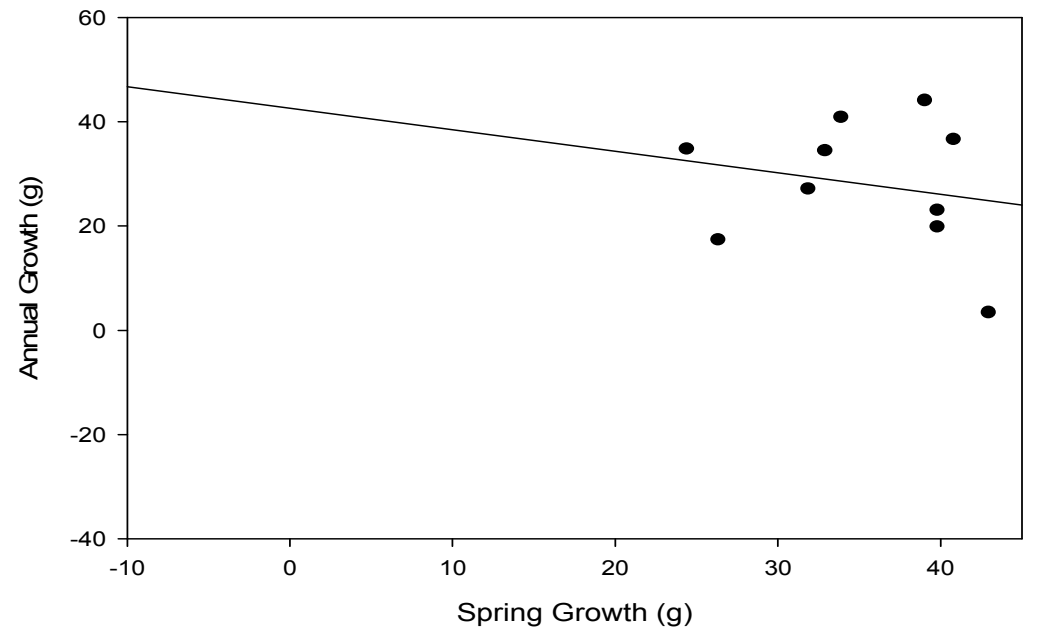

(d) 


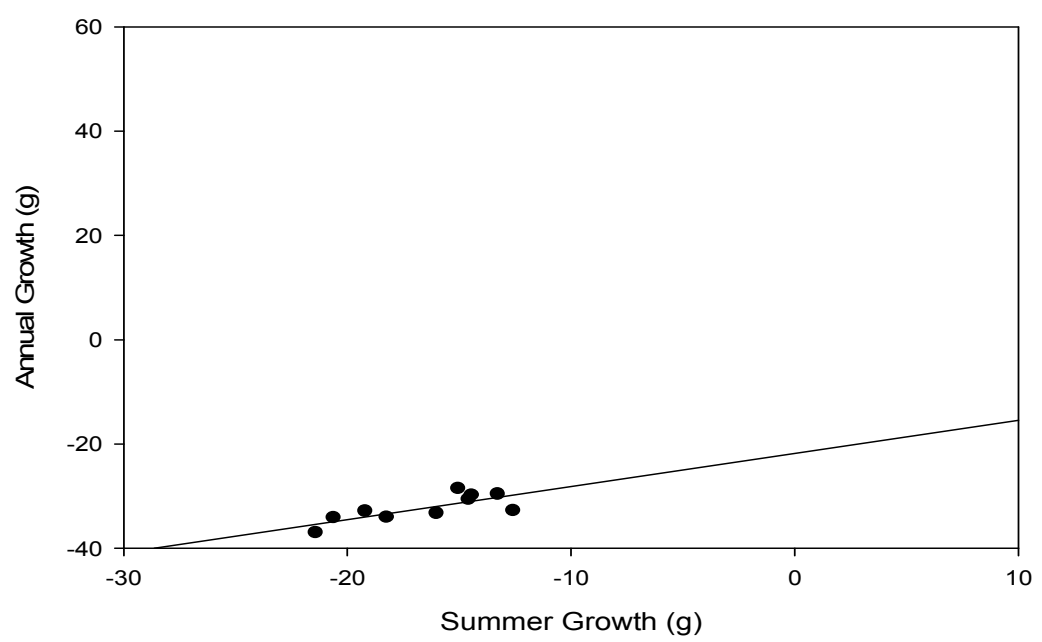

(a)

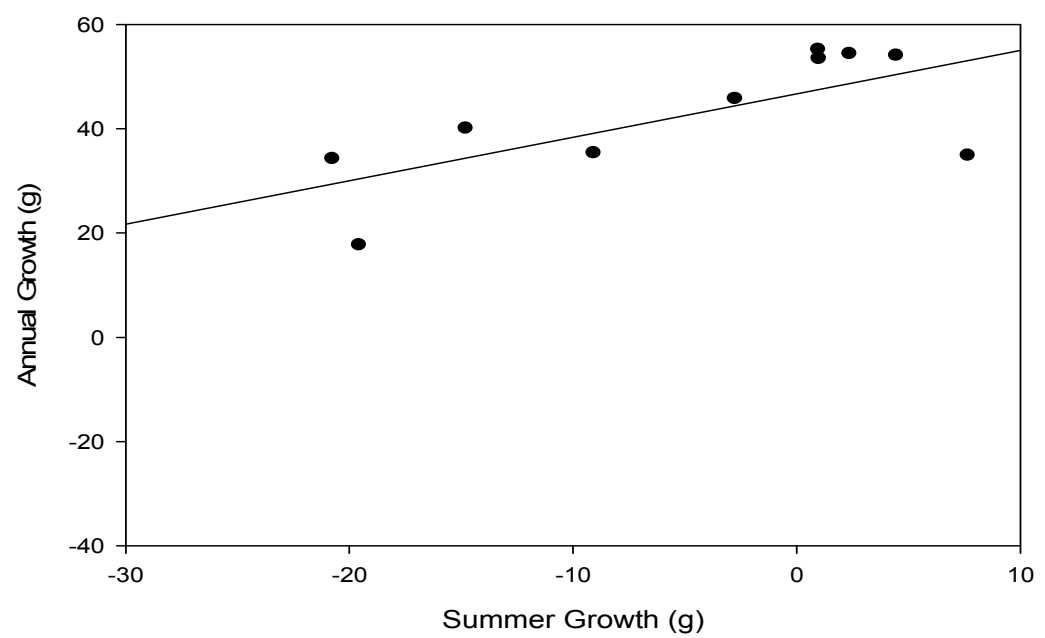

(c)

Figure 24. Correlation between summer and anthual growth tributary $\left(\mathrm{R}^{2}=0.68\right)(\mathrm{c})$ cool mainstem $\left(\mathrm{R}^{2}=0.48\right)(\mathrm{d})$ warm mainstem $\left(\mathrm{R}^{2}=0.45\right)$

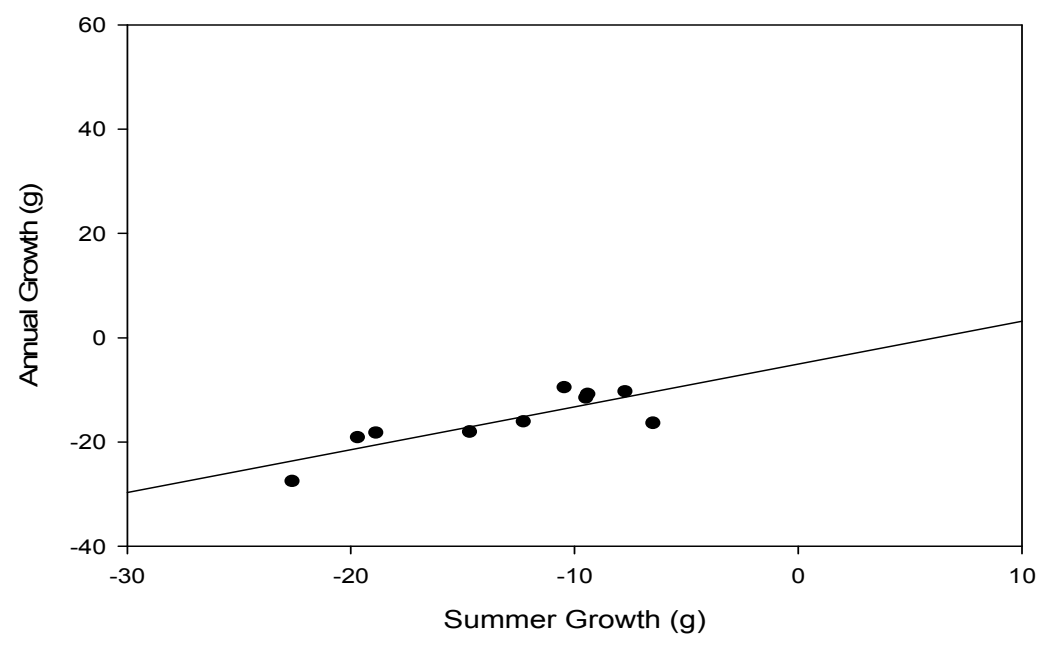

(b)

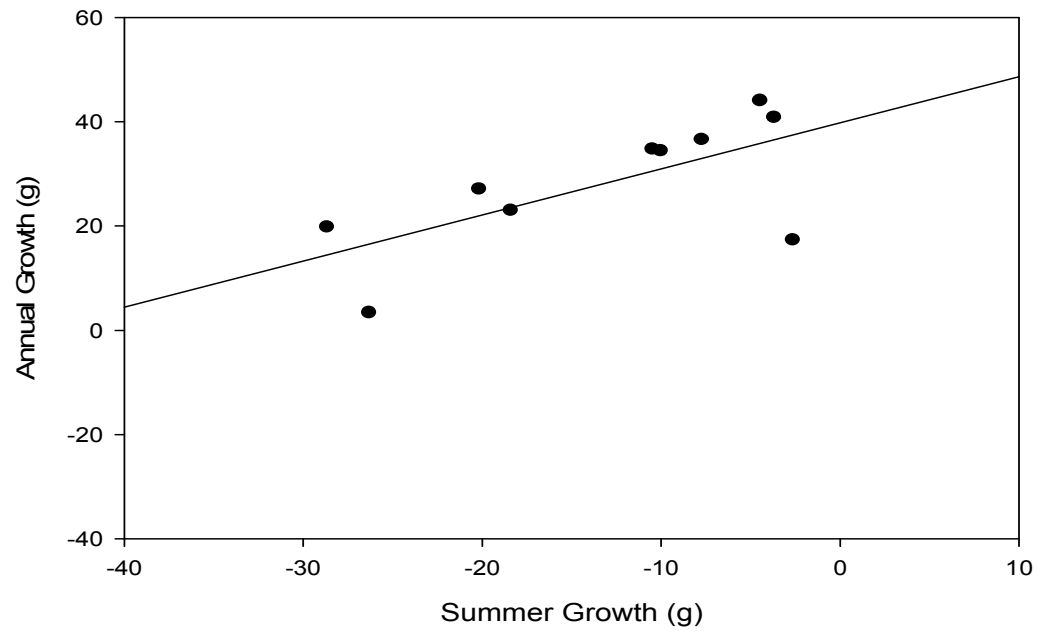

(d) 


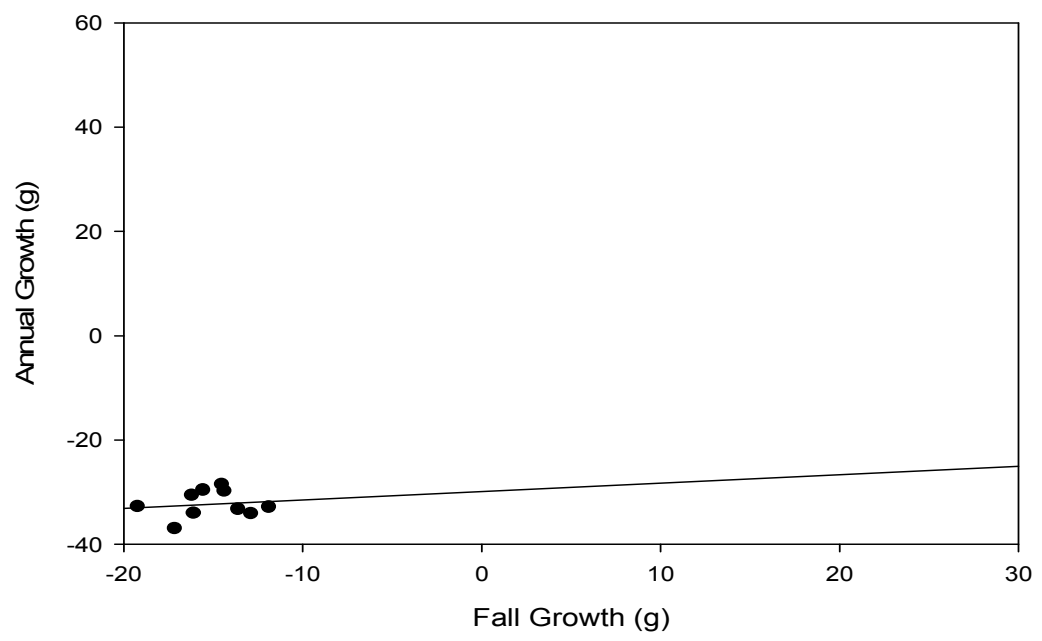

(a)

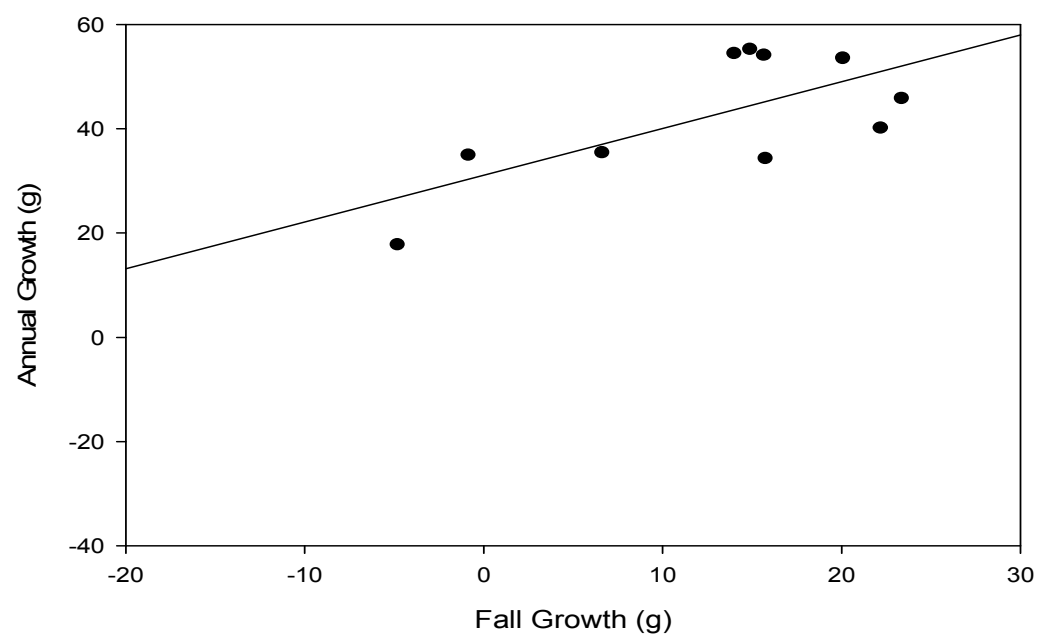

(c)

Figure 25. Correlation between fall and annual growth ( $\mathrm{g}$ ) for a $50 \mathrm{~g}$ brook trout in a (a) small tributary $\left(\mathrm{R}^{2}=0.02\right)(\mathrm{b})$ large tributary $\left(\mathrm{R}^{2}=0.17\right)$ (c) cool mainstem $\left(\mathrm{R}^{2}=0.48\right)(\mathrm{d})$ warm mainstem $\left(\mathrm{R}^{2}=0.53\right)$.

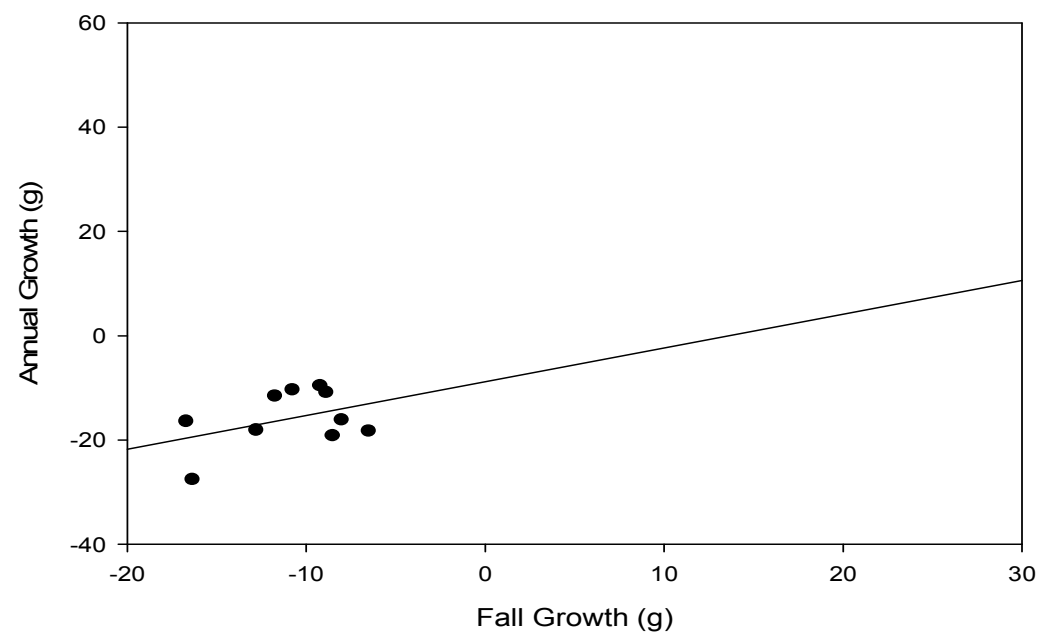

(b)

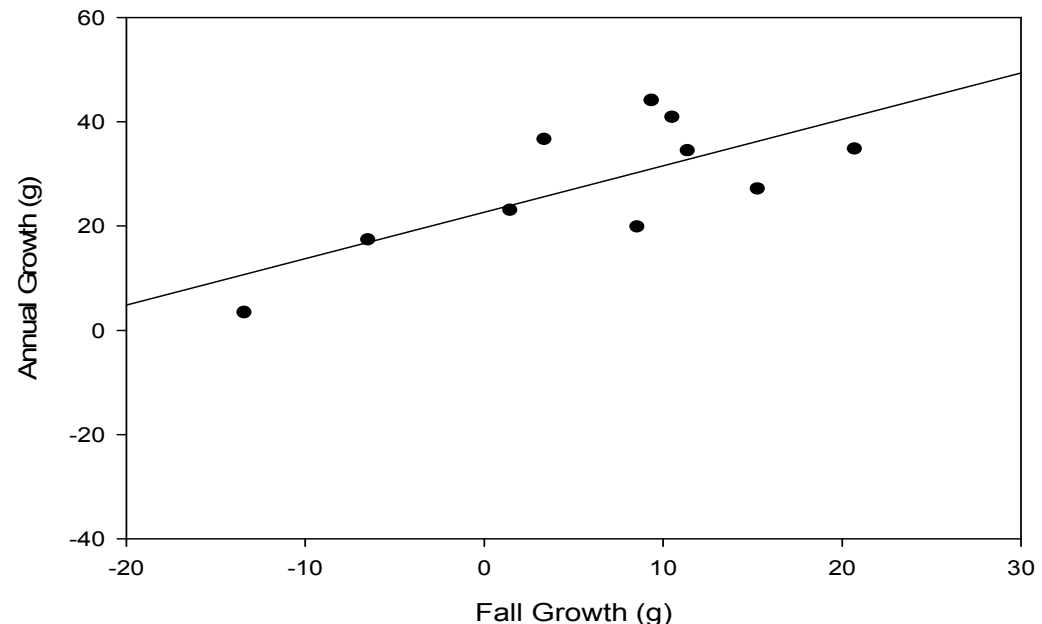

(d) 


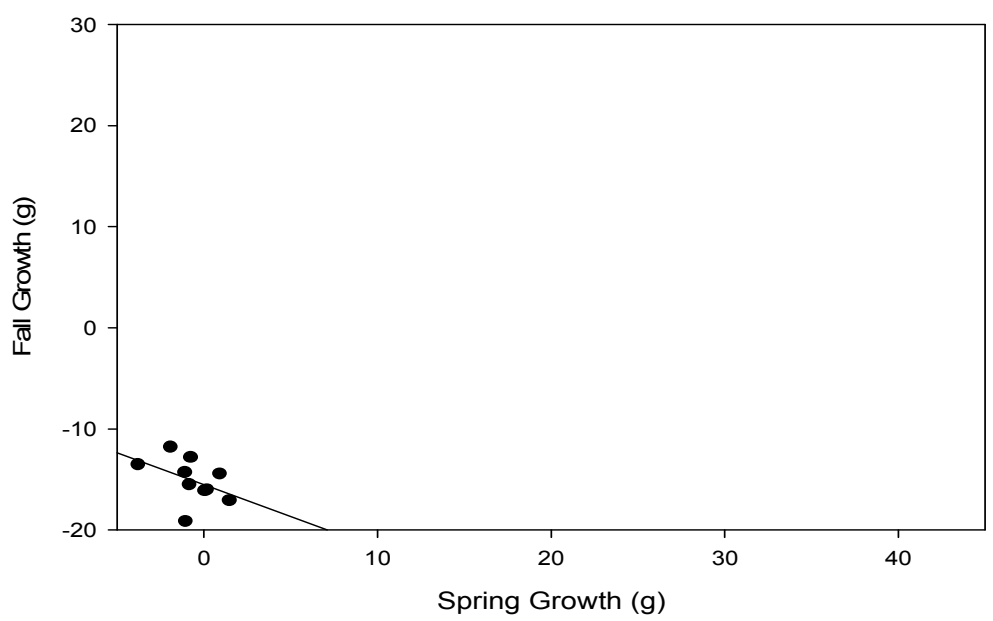

(a)

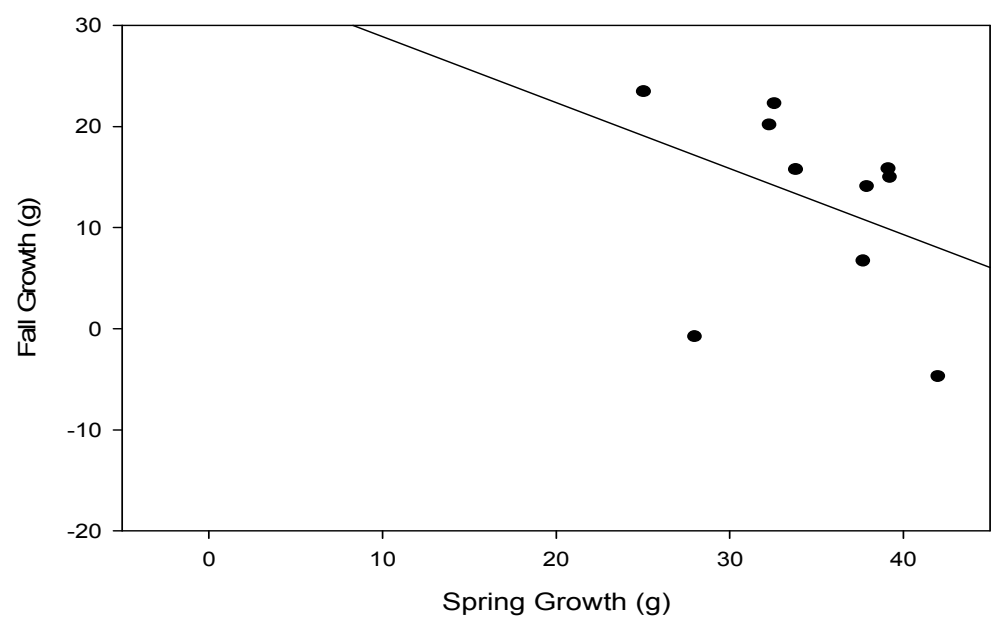

(c)

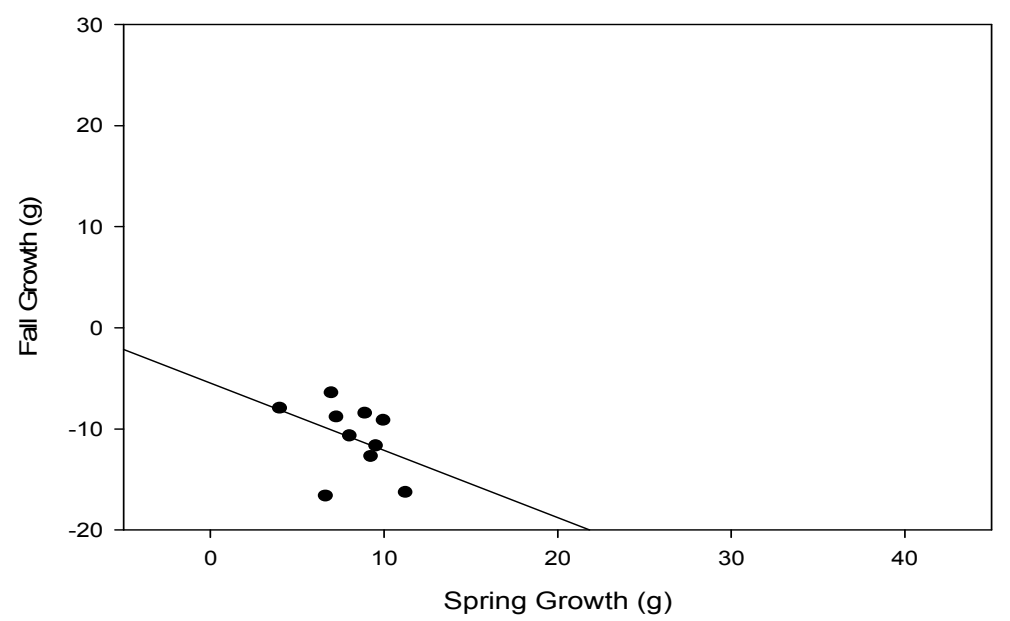

(b)

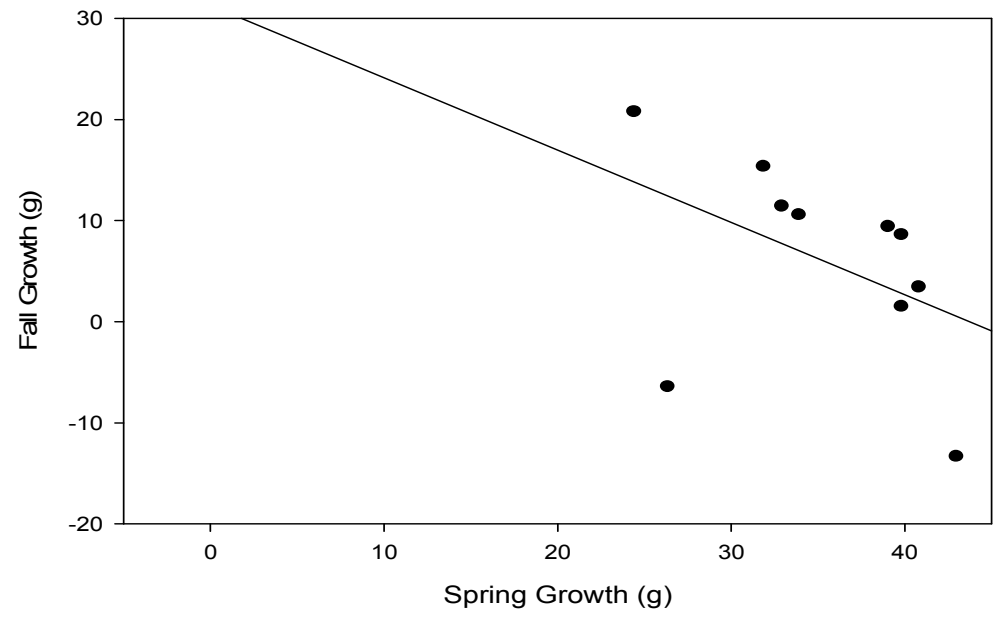

(d)

Figure 26. Correlation between spring and fall growth (g) for a $50 \mathrm{~g}$ brook trout in a (a) small tributary $\left(\mathrm{R}^{2}=0.19\right)(\mathrm{b})$ large tributary $\left(\mathrm{R}^{2}=0.16\right)(\mathrm{c})$ cool mainstem $\left(\mathrm{R}^{2}=0.14\right)$ and $(\mathrm{d})$ warm mainstem $\left(\mathrm{R}^{2}=0.20\right)$. 


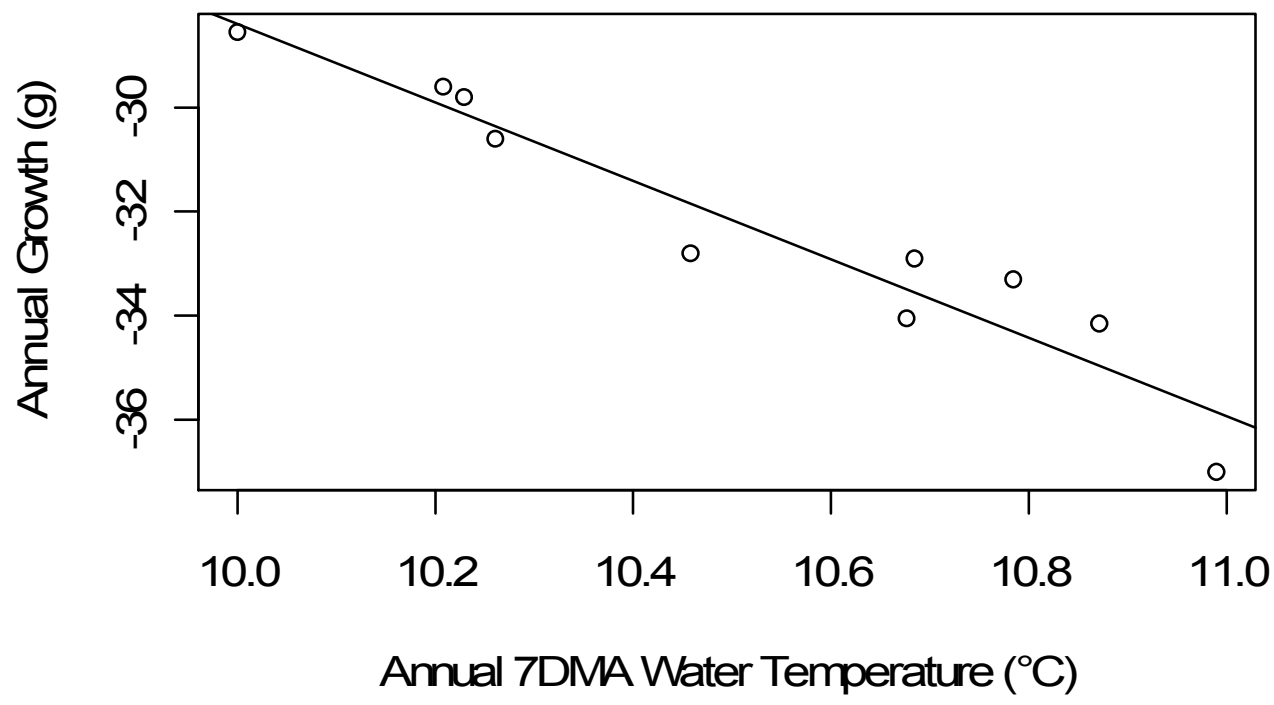

Figure 27. Correlation between annual 7DMA water temperature $\left({ }^{\circ} \mathrm{C}\right)$ and annual growth (g) for a $50 \mathrm{~g}$ brook trout in a small tributary $\left(\mathrm{R}^{2}=0.92\right)$.

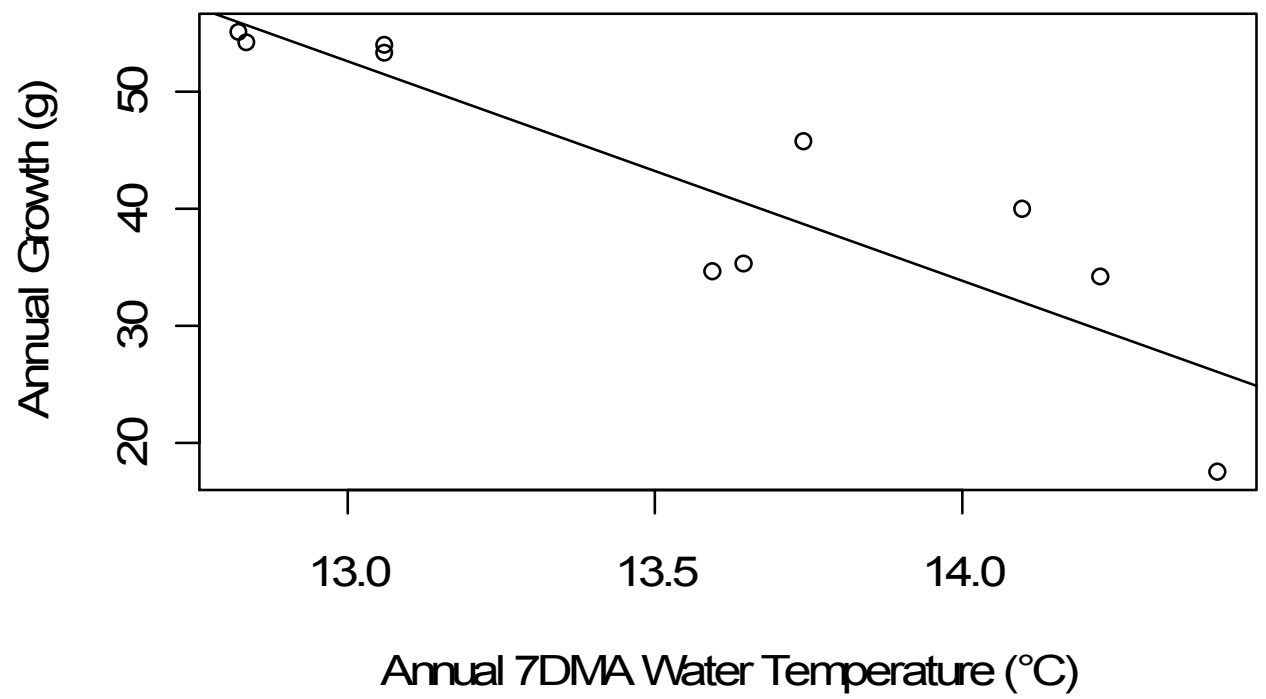

Figure 28. Correlation between annual 7DMA water temperature $\left({ }^{\circ} \mathrm{C}\right)$ and annual growth (g) for a $50 \mathrm{~g}$ brook trout in a cool mainstem $\left(\mathrm{R}^{2}=0.79\right)$. 


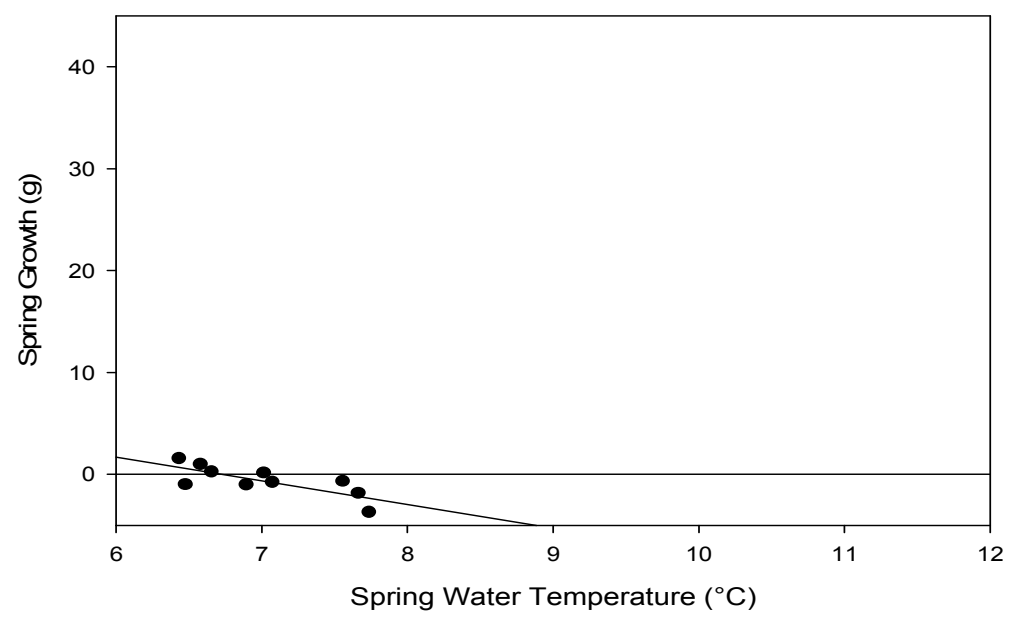

(a)

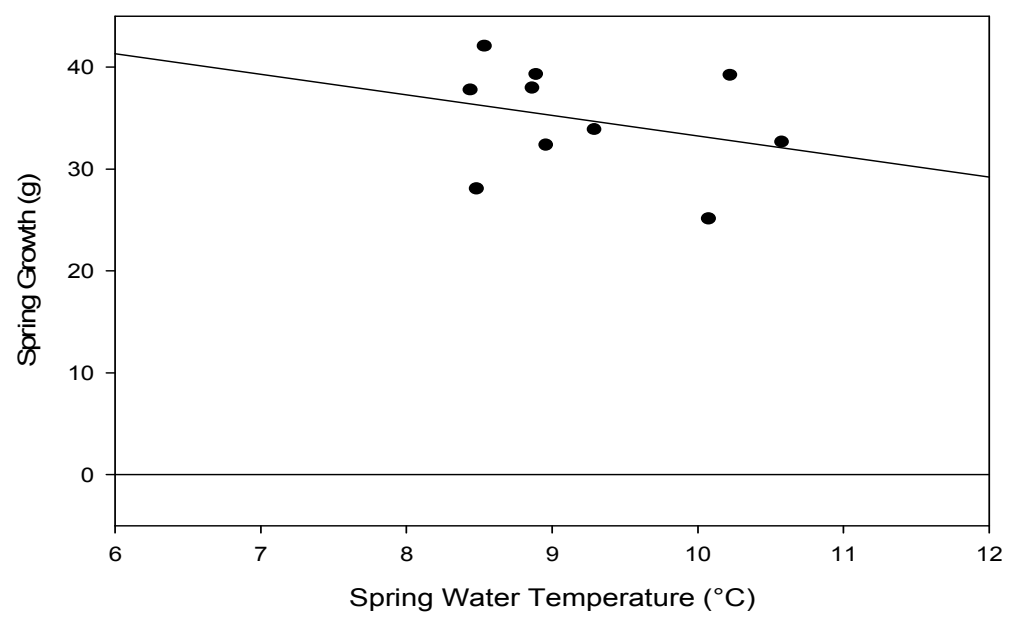

(c)

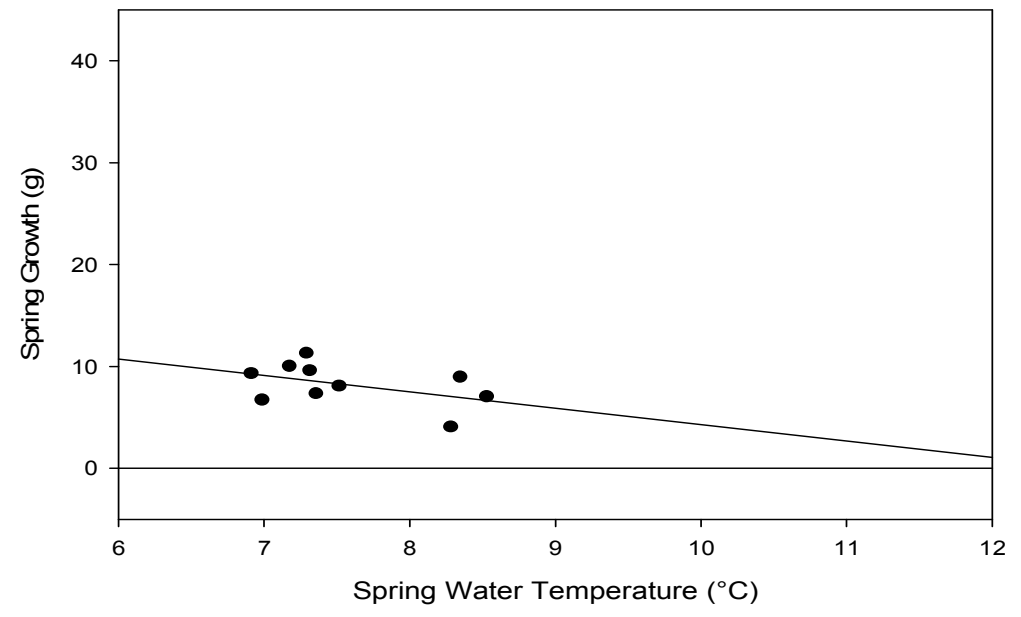

(b)

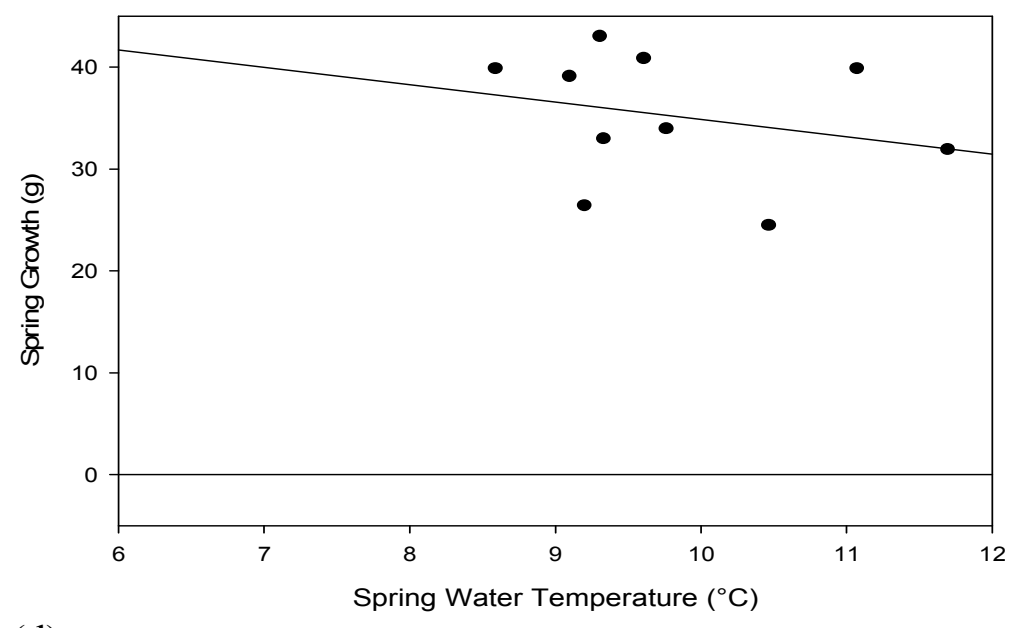

(d)

Figure 29. Correlation of spring 7DMA water temperature $\left({ }^{\circ} \mathrm{C}\right)$ and growth $(\mathrm{g})$ for a $50 \mathrm{~g}$ brook trout in a (a) small tributary $\left(\mathrm{R}^{2}=0.59\right)$, (b) large tributary $\left(\mathrm{R}^{2}=0.21\right)$, (c) cool mainstem $\left(\mathrm{R}^{2}=0.09\right)$, and $(\mathrm{d})$ warm mainstem $\left(\mathrm{R}^{2}=0.07\right)$. 


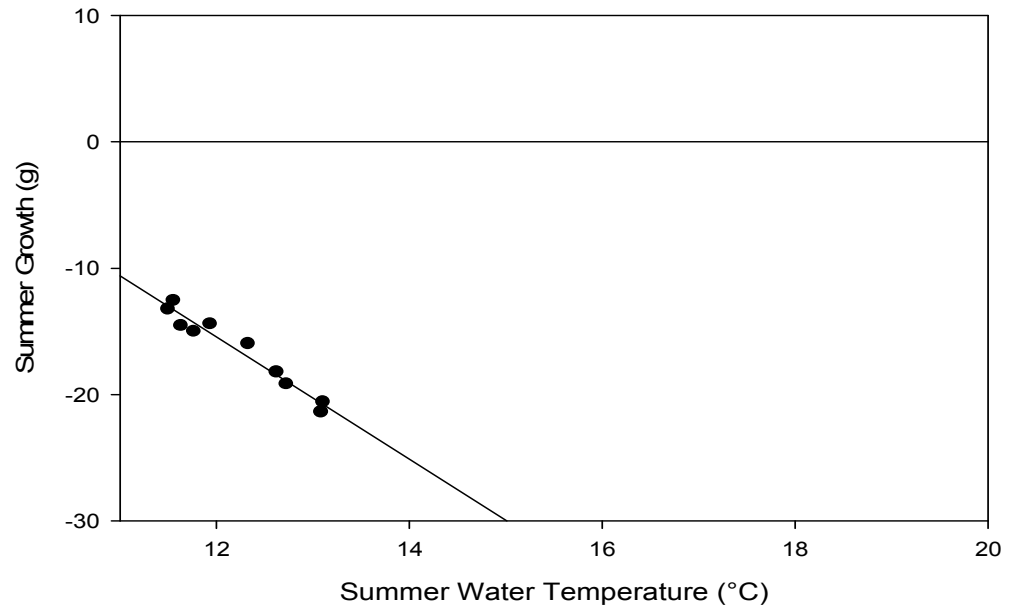

(a)

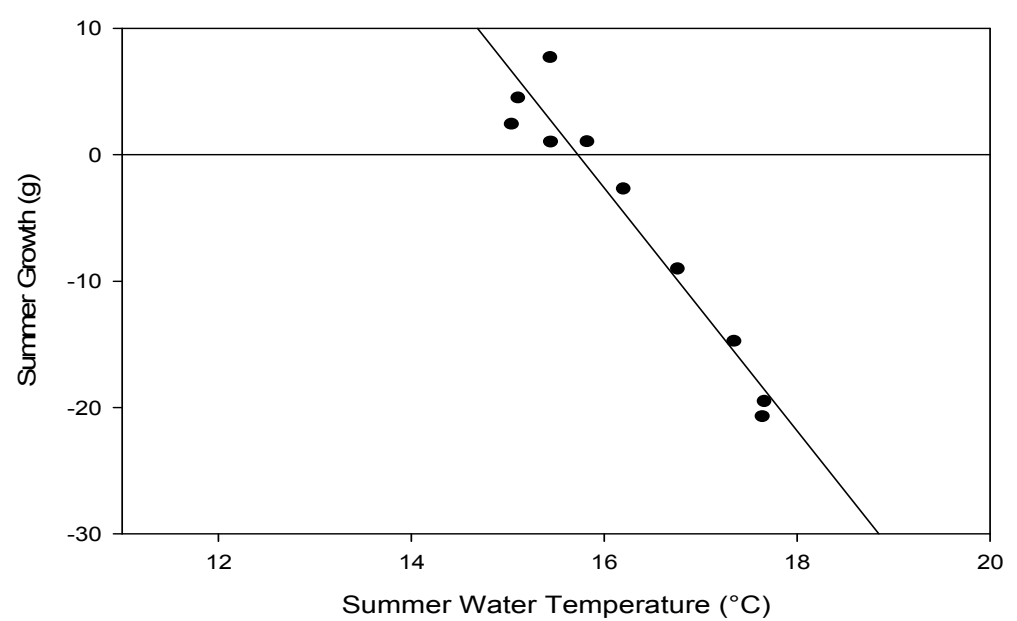

(c)

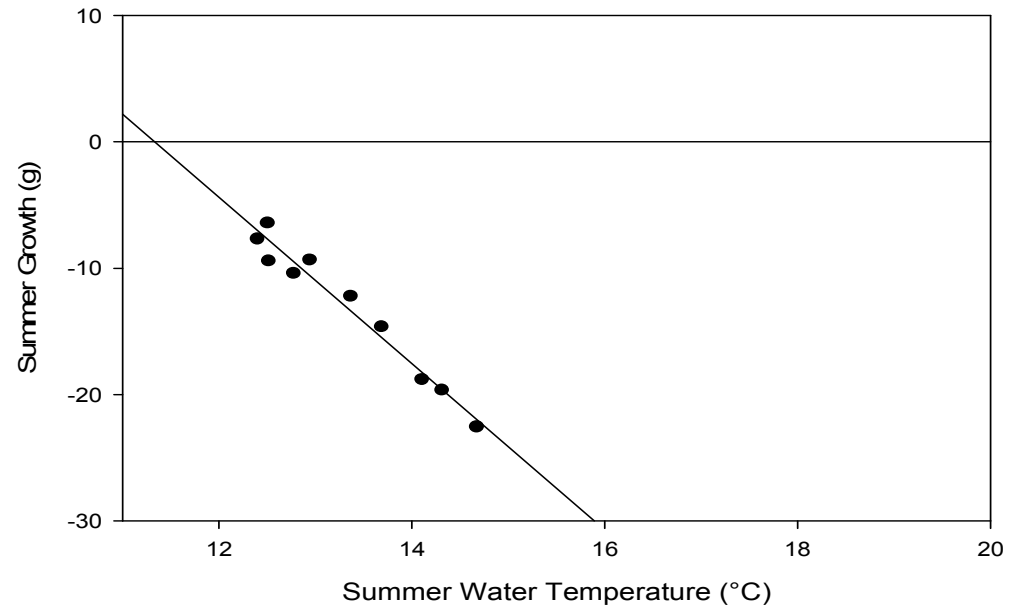

(b)

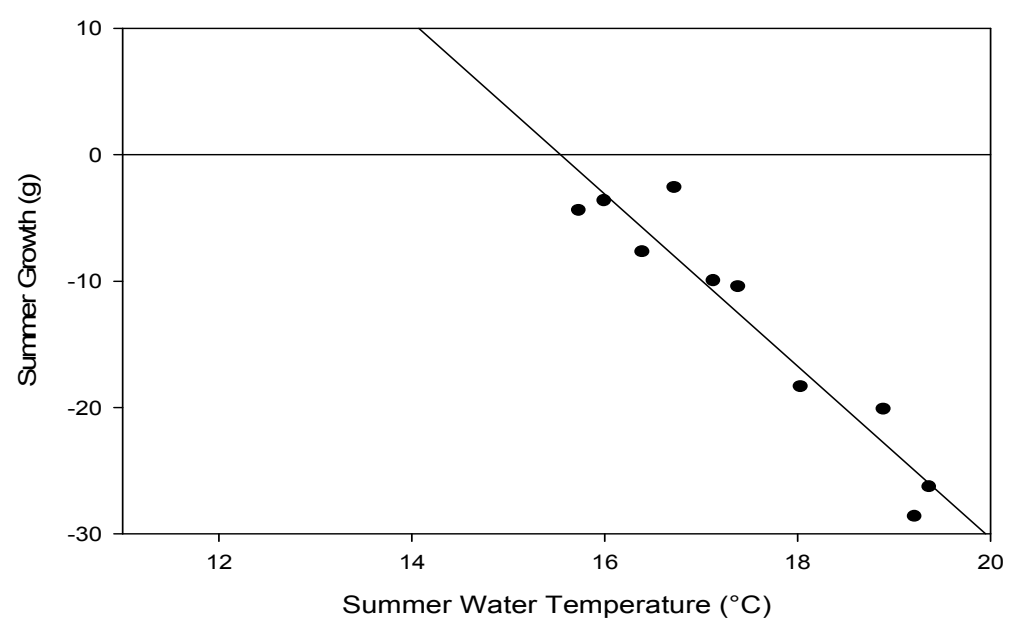

(d)

Figure 30. Correlation of summer 7DMA water temperature $\left({ }^{\circ} \mathrm{C}\right)$ and growth $(\mathrm{g})$ for a $50 \mathrm{~g}$ brook trout in a (a) small tributary $\left(\mathrm{R}^{2}=0.95\right)$, (b) large tributary $\left(\mathrm{R}^{2}=0.96\right)$, (c) cool mainstem $\left(\mathrm{R}^{2}=0.94\right)$, and $(\mathrm{d})$ warm mainstem $\left(\mathrm{R}^{2}=0.91\right)$. 


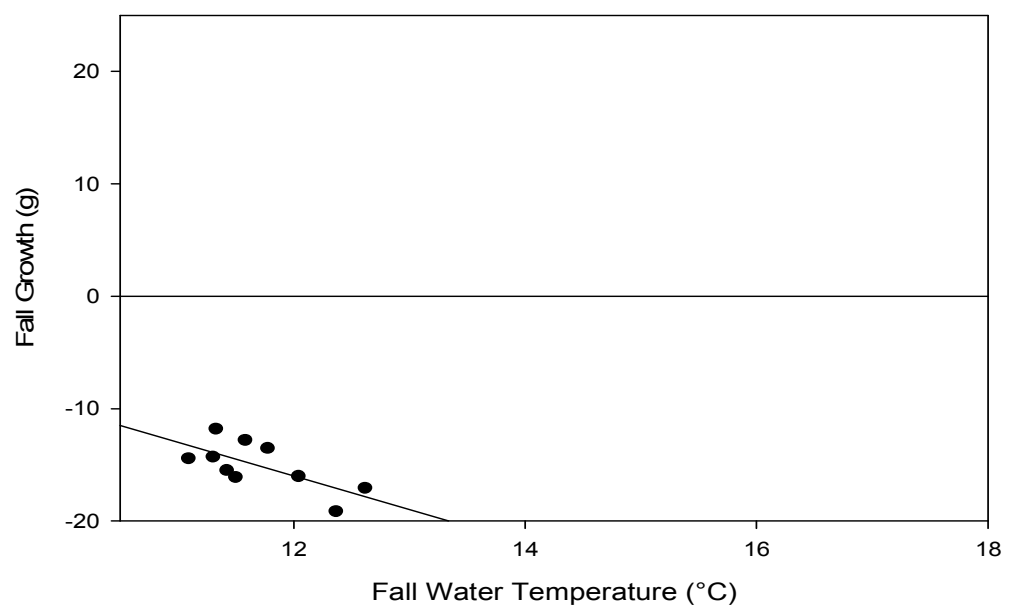

(a)

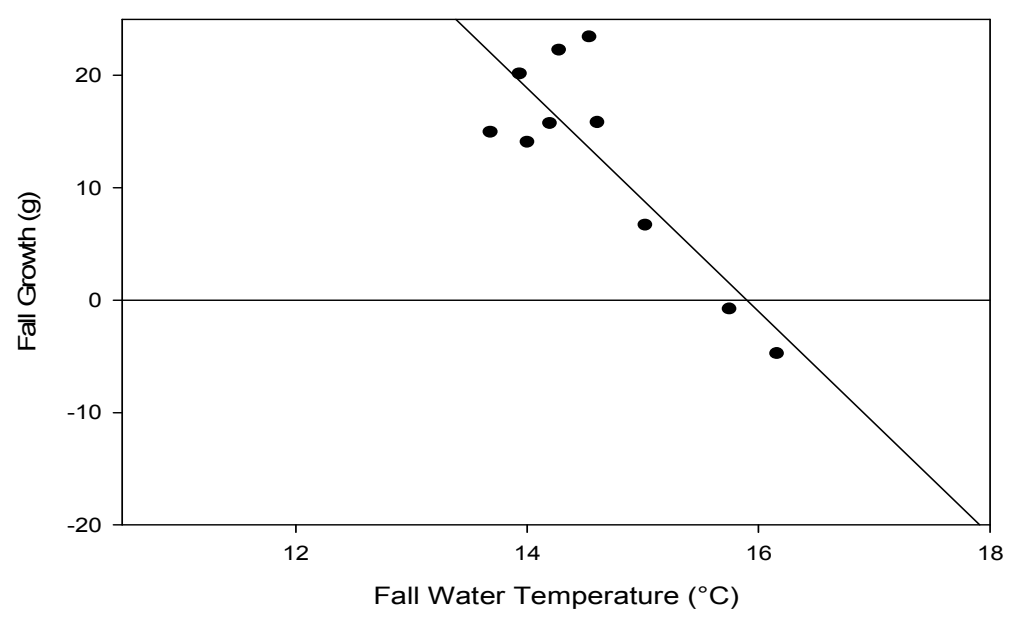

(c)

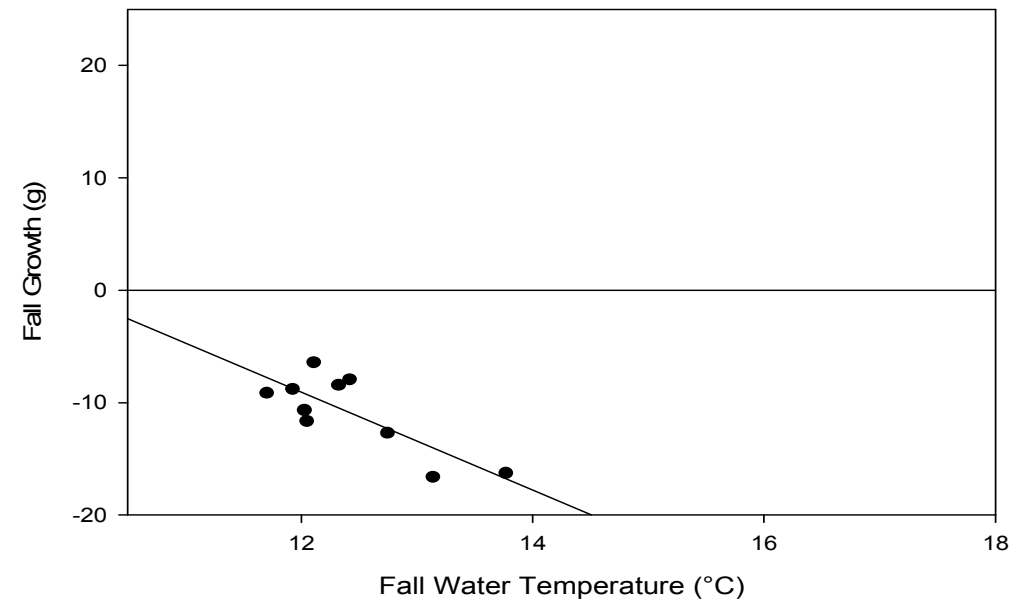

(b)

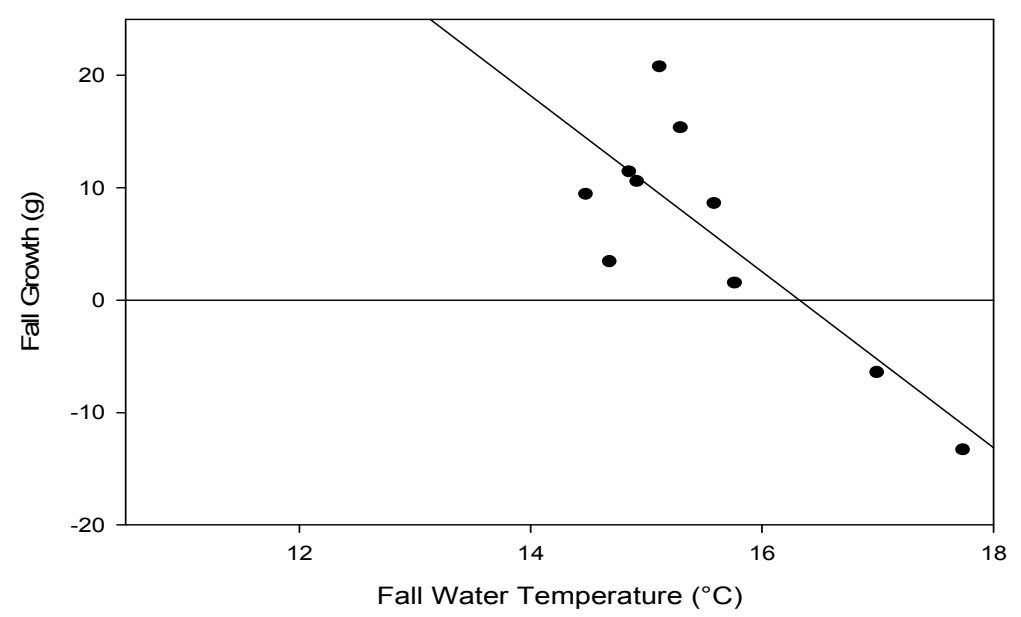

(d)

Figure 31. Correlation of fall 7DMA water temperature $\left({ }^{\circ} \mathrm{C}\right)$ and growth $(\mathrm{g})$ for a $50 \mathrm{~g}$ brook trout in a (a) small tributary $\left(\mathrm{R}^{2}=0.47\right)$, (b) large tributary $\left(\mathrm{R}^{2}=0.63\right)$, (c) cool mainstem $\left(\mathrm{R}^{2}=0.71\right)$, and $(\mathrm{d})$ warm mainstem $\left(\mathrm{R}^{2}=0.66\right)$. 
